\title{
AEROSOL BEHAVIOR DURING SODIUM POOL FIRES IN A LARGE VESSEL - CSTF TESTS AB1 AND AB2
}

This report was prepared as an account of work

sponsored by the United States Government. Neither the

United States nor the United States Department of

Energy, nor any of their employees, nor any of their

contractors, subcontractors, or their employees, makes

any warranty, express or implied, or assumes any legal

liability or responsibility for the accuracy, completeness

or usefulness of any information, apparatus, product or

process disclosed, or represents that its use would not

infringe privately owned rights.

This document is

PUBLICLY RELEASABLE

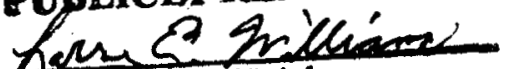
Authorrzing Official

Date: $03 / 10 / 2006$

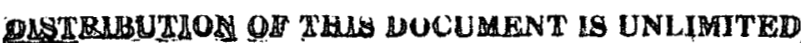
HANFORD ENGINEERING DEVELOPMENT LABORATORY Operated by Westinghouse Hanford Company P.0. Box 1970 Richland, WA 99352 A Subsidiary of Westinghouse Electric Corporation Prepared for the U.S. Department of Energy under Contract No. DE-AC14-76FF02170. 


\section{DISCLAIMER}

This report was prepared as an account of work sponsored by an agency of the United States Government. Neither the United States Government nor any agency Thereof, nor any of their employees, makes any warranty, express or implied, or assumes any legal liability or responsibility for the accuracy, completeness, or usefulness of any information, apparatus, product, or process disclosed, or represents that its use would not infringe privately owned rights. Reference herein to any specific commercial product, process, or service by trade name, trademark, manufacturer, or otherwise does not necessarily constitute or imply its endorsement, recommendation, or favoring by the United States Government or any agency thereof. The views and opinions of authors expressed herein do not necessarily state or reflect those of the United States Government or any agency thereof. 


\section{DISCLAIMER}

Portions of this document may be illegible in electronic image products. Images are produced from the best available original document. 
HEDL-TME 79-28

\title{
AEROSOL BEHAVIOR DURING SODIUM POOL FIRES IN A LARGE VESSEL CSTF TESTS ABT AND AB2 (FF287)
}

\author{
R. K. Hilliard \\ J. D. McCormack \\ A. K. Postma
}

\begin{abstract}
Two large-scale aerosol behavior tests, using sodium pool fires as the aerosol source, were performed in the Containment Systems Test Facility (CSTF). The tests were conducted to characterize the properties and behavior of sodivm aerosol particles formed and aged in a large containment vessel. The $20-m$ high, $850-\mathrm{m}^{3}$ CSTF containment vessel is approximately half the size of a commercial reactor containment building in regard to parameters that affect agglomeration and gravitational settling.

In both tests, sodium bumed for one hour in a $4.38-\mathrm{m}^{2}$ pool, and the only difference between them was that steam was injected during the second test, simulating the release of water vapor from heated concrete. In the first test ("dry" test ABI), the aerosol was a dry mixture of sodium peroxide, sodium hydroxide, and sodium carbonate; in the second test ("wet" test AB2), it was predominantly wet sodium hydroxide. The additional water vapor caused more rapid fallout during the aerosol release period and lower settling rates afterwards. The net effect was minor, and the time-integrated suspended aerosol concentration was comparable for the two tests.

While the tests were conducted primarily to obtain baseline data on aerosol parameters for use in follow-on air cleaning tests, the two runs also provided experimental information for the evaluation of existing aerosol codes. In both tests, aerosol particle sizes and airborne concentrations were in good agreement with predictions made with the HAA-3B computer code.

Air cleaning tests will be performed next in this facility to demonstrate the effectiveness of various types of scrubbers, filters, and novel devices for cleaning the very high mass concentration aerosol from the containment atmosphere.
\end{abstract}




\section{ACKNOWLEDGEMENTS}

A large part of the work reported herein was performed by the staff of the Safety Systems Development Group at the Hanford Engineering Development Laboratory (HEDL), and the authors wish to acknowledge their efforts. Of particular note were the contributions of L. D. Muhlestein, Manager, and R. M. Steele, Lead Technician. G. W. Oblisk assisted significantly in the detailed test preparations. Much of the chemical analysis was performed by R. F. Keough and D. L. Baldwin; electron microscopy was performed by B. Mastel; and pretest $H A A-3 B$ computer code analyses were performed by $\mathrm{J}$. A. Hassberger. HAARM-3 analyses were performed by J. A. Gieseke, Battelle Columbus Laboratory.

The work covered by this report was sponsored by the U.S. Department of Energy, Fast Reactor Safety Branch. A. C. Millunzi, Chief, and Carl Newton were especially helpful during planning stages. 


\section{CONTENTS}

$\begin{array}{lr} & \frac{\text { Page }}{\text { FIGURES }} \\ \text { TABLES } & \text { xix }\end{array}$

I. SUMMARY AND CONCLUSIONS 1

A. SUMMARY 1

B. CONCLUSIONS 1

II. INTRODUCTION 5

III. TEST OBJECTIVES 7

IV. EXPERIMENTAL FACILITY AND PROCEDURE 9

A. CSTF CONTAINMENT VESSEL 9

B. EXPERIMENTAL INSTRUMENTATION 12

1. Temperature Measurement 12

2. Pressure Measurement 12

3. Aerosol Sampling Instruments 13

4. Data Acquisition 22

C. EXPERIMENTAL PROCEDURE 22

D. CHEMICAL ANALYSIS 25

$\begin{array}{ll}\text { E. TEST CONDITIONS } & 26\end{array}$

$\begin{array}{ll}\text { V. EXPERIMENTAL RESULTS } & 27\end{array}$

A. VISUAL OBSERVATIONS 27

B. CONTAINMENT ATMOSPHERE RESPONSE 28

C. AEROSOL SOURCE TERM 30

D. AEROSOL CHEMICAL FORM 31

E. SUSPENDED MASS CONCENTRATION 33

F. AEROSOL PARTICLE SIZE DISTRIBUTION 36 
G. AEROSOL PHYSICAL PROPERTIES 43

1. Particle Shape and Density 43

2. Particle Electric Charge 44

3. Butk Density of Deposited Powder 46

H. SODIUM MASS BALANCE $\quad 47$

1. Burn Pan Residue Analysis 47

2. Analysis of Deposited Aerosol Mass 49

3. Distribution of Deposited Aerosol Mass 51

4. Overall Sodium Balance 55

I. ENERGY RELEASE AND SODIUM OXIDATION RATE 56

1. Thermal Energy Balance 56

2 Sodium Oxidation Rate 59

3. Oxygen Consumption 60

4. Atmospheric Gas Consumption 63

VI. COMPARISON OF SOFIRE-II CODE PREDICTIONS WITH 65 EXPERIMENT

A. PRETEST PREDICTIONS .. 65

B. POSTTEST PARAMETER FIT 67

VII. COMPARISON OF AEROSOL COMPUTER CODES WITH 71 EXPERIMENT

A. PRETEST PREDICTIONS 71

1. Airborne Mass Concentration 71

2. Mass Leaked From Vessel 74

B. POSTTEST PARAMETER FIT 76

1. Floor Area of Vessel 77

2. Initial Particle Size 78

3. Density Modification Factor and 83

4. Effect of Water Vapor Uptake on 84

C. COMPARISON BETWEEN PREDICTED AND MEASURED 94

PARAMETERS

1. Particle Size 94

2. Plated Mass 99 
Page

D. CONCLUSIONS REGARDING HAA-3B MODEL PREDICTIONS 101

VIII. EFFECT OF WATER VAPOR ON AEROSOL BEHAVIOR 103

$\begin{array}{lll}\text { IX. REFERENCES } & 105\end{array}$

APPENDICES:
A - TABLES OF FILTER SAMPLE DATA
B - CASCADE IMPACTOR DATA
C - DEPOSITION COUPON DATA
D - CODE INPUT PARAMETERS
E - INSTRUMENTATION
F - THERMAL DATA 


\section{FIGURES}

Page

1. External View of CSTF Containment Vessel.

2. CSTF Aerosol Behavior Test Arrangement Used for Tests AB1 and $A B 2$.

3. Bottom View of an In-Vessel Cluster Sampler.

4. Through-the-Wall Sampling Stations Used in CSTF Aerosol Tests.

5. Filter Holder Used With In-Vessel Samplers and in Through-theWal1 Sample Withdrawal.

6. Circular Jet Impactor.

7. Rectangular Jet Impactor.

8. Gravity Settling Sampler.

9. Particle Electrical Mobility Analyzer.

10. Exposure Slide Used to Obtain Particle Samples for Electron Microscopy.

11. View of Sodium Spilling Into ABI Burn Pan 10 Seconds After Start of Spill.

12. View of Vessel Interior Showing Deposited Aerosol - Test AB1

13. Visual Range in a Closed Vessel During a Sodium Pool Fire. 27

14. Containment Temperature and Pressure - Test AB1. 28

15. Containment Temperature and Pressure - Test AB2. 29

16. Mass Fraction of Sodium in Suspended Aerosol. 32

17. Suspended Mass Concentration - Test AB1. 33

18. Suspended Mass Concentration - Test AB2. 36

19. Typical Cascade Impactor Data Plot on Log-Normal Coordinates. 37

20. Aerodynamic Mass Median Diameter of Suspended Particles. 38

21. Geometric Standard Deviation of Suspended Particle Size. 39

22. Comparison of Aerodynamic Sett1ing Diameters From Cascade 40 Impactor and Airborne Depletion Data - Test AB1. 
23. Comparison of Aerodynamic Settling Diameter From Cascade Impactor and Airborne Depletion Data - Test AB2.

24. Comparison of Particle Size Inferred From Deposition Coupons With Other Size Measurements in Test ABT.

25. Comparison of Particle Size Inferred From Deposition Coupons With Other Size Measurements in Test AB2.

26. Electron Photomicrographs of Gravity-Settled Particles at Various Times in Test $A B 1$.

27. Sensible Heat of CSTF Vessel and Internals.

28. Oxygen Concentration During Sodium Fires.

29. 0xygen Consumption Based on Measured $\mathrm{O}_{2}$ Concentration and

30. Oxygen Consumption Based on Measured $\mathrm{O}_{2}$ Concentration and

31. Comparison of Measured Gas Temperature With Pretest SOFIRE-II Prediction.

32. Comparison of Measured Gas Pressure With Pretest SOFIRE-II Prediction.

33. Comparison of Measured Gas Temperatures With Posttest SOFIRE-II Prediction.

34. Comparison of Measured Gas Pressure With Posttest SOFIRE-II Prediction.

35. Comparison of Measured and Predicted Sodium Temperatures in Test $A B T$.

36. Pretest Predictions Made by the HAA-3B Code.

37. Pretest Prediction Made by the HAARM-3 Code.

38. Pretest Prediction of Leaked Mass Based on the HAA-3B Code. 75

39. Pretest Prediction of Leaked Mass Based on HAARM-3 Code. 76

40. Effect of Horizontal Area on Predicted Aerosol Concentration. 77

41. Predicted Effect of Horizontal Settling Area on Leaked Mass. 79 
42. Effect of Source Particle Size on Predicted Aerosol

Concentration.

43. Predicted Aerosol Concentration for 1- and 12-um Diameter

Particles.

44. Predicted Effect of a Twelvefold Increase in Source Particle Size on Leaked Mass.

45. Effect of $\alpha \varepsilon$ Product on Predicted Aerosol Concentration.

46. Effect of $\alpha \varepsilon$ Product on Predicted Leaked Mass for Test AB2.

47. Comparison of Measured and Predicted Aerosol Concentrations for Test $A B 1$.

48. Comparison of Measured and Predicted Airborne Concentrations in Test $A B 2$.

49. Comparison of Predicted and Measured Aerosol Mass Leaked for Test ABI When Water Vapor Uptake is Accounted for.

50. Comparison of Predicted and Measured Aerosol Mass Leaked for Test AB2 When Water Vapor Uptake is Accounted for.

51. Posttest Fit of HAARM-3 with Test $A B 1$.

52. Posttest Prediction of Leaked Mass by HAARM-3 for Test ABI.

53. Posttest Fit of HAARM-3 with Test AB2.

54. Posttest Prediction of Leaked Mass by HAARM-3 for Test AB2.

55. Measured and Predicted Particle Size in Test ABI.

56. Comparison of Measured and Predicted Settling Mean Particle Diameters in Test $A B 1$.

57. Comparison of Measured and Predicted Mean Particle Diameters in Test AB2.

58. Comparison of Measured and Predicted Settling Mean Particle Diameters in Test AB2. 


\section{$\underline{T A B L E S}$}

Page

1 Test Conditions for CSTF Tests ABI and AB2 11

2 Through-the-Wall Sampling Station Locations 16

3 Sodium Oxidation and Aerosol Release 30

4 Aerosol Chemical Analysis - Test AB1 31

5 Suspended Mass Concentration - Test AB1 34

6 Suspended Mass Concentration - Test AB2 35

7 Particle Charge Distribution $\quad 46$

8 Chemical Analysis of Burn Pan Residue - Test AB1 48

9 Chemical Analysis of Burn Pan Residue - Test AB2 49

10 Chemical Form of Reaction Products - Test ABT 50

11 Chemical Form of Reaction Products - Test AB2 51

12 Settled Mass Measured by Deposition Trays - Test AB1 52

13 Settled Mass Measured by Deposition Trays - Test AB2 53

14 Sodium Plated on Vertical Wall - Test AB? 54

15 Distribution of Deposited Sodium Within CV - Test ABI 54

16 Distribution of Deposited Sodium Within CV - Test AB2 55

17 Sodium Mass Balance 56

18 Sensible Heat Gains in CSTF Components for Test AB1 58

19 Sensible Heat Gains in CSTF Components for Test AB2 58

20 Sodium Burning Rate Variation With Time 60

21 Composition of Containment Atmosphere - Test AB1 63

22 Composition of Containment Atmosphere - Test AB2 64

23 Comparison of Posttest SOFIRE-II Code Predictions with 70 $A B 1$ Test Results 
$\underline{\text { Page }}$

24 Aerosol Generation Rate Calculated for 10\% Aerosolization

25 Effect of Source Particle Size on Leaked Mass

81

26 Time-Dependent Aerosol Source Rate Based on Measured Aerosolization and Water Vapor Availability

27 Comparison of Measured and Predicted Plateout in CSTF PoolFire Tests 


\section{SUMMARY AND CONCLUSIONS}

\section{A. SUMMARY}

Two aerosol behavior tests were carried out in the Containment Systems Test Facility (CSTF) to characterize the properties of sodium-compound aerosol particles formed and aged in a large containment vessel. In both tests the aerosol source was a $4.38-\mathrm{m}^{2}$ pool fire that burned for one hour. To ensure a fairly uniform aerosol source rate, a large surplus of sodium was used, and the pool lid was closed after one hour to stop the aerosol release.

One of the tests ("dry" test $A B 1$ ) used an ambient air atmosphere; the other test ("wet" test AB2) had added steam, simulating water released from heated concrete.

While the tests were primarily conducted to develop baseline data for followon air cleaning tests, the results of these large-scale tests also provided important data for the evaluation of available computer codes.

\section{B. CONCLUSIONS}

Results obtained from the two pool-fire tests support the following conclusions and summary statements:

- In both tests, aerosol mass concentration had increased to a maximum of: $\sim 30 \mathrm{~g} / \mathrm{m}^{3}$ by the end of the fire period.

- The containment atmosphere was well mixed, as evidenced by the uniformity of aerosol samples withdrawn simultaneously from 10 locations in the vessel atmosphere.

- The particle size distribution of the aerosol was approximated fairly well by a log-normal function. The aerodynamic mass median diameter (AMMD) attained a value of $5.5 \mu \mathrm{m}$ at $1000 \mathrm{~s}$ and remained nearly constant until the source was terminated. The geometric standard deviation, $\sigma_{g}$, was $\sim 2.7$ during the 
source-release period. After source termination, settling reduced the particle size until the AMMD was $\sim 2.0 \mu \mathrm{m}, \sigma_{\mathrm{g}} 2.7$ at $27 \mathrm{hr}$.

- Gravity settling was the dominant particle removal mechanism. Less than $10 \%$ of the aerosot plated on vertical vessel walls.

- The effect of added steam was minor. Although more rapid settling occurred during the source period in the wet test $(A B 2)$, it was less rapid after source termination. The timeintegrated airborne concentration indicated that a smaller fraction of aerosolized sodium leaked from the vessel in Test $A B 2$.

- In the normal air atmosphere or dry test ( $A B 1$ ), aerosolized sodium was present in the atmosphere as a mixture of sodium peroxide and sodium hydroxide. In the burn pan residue, the monoxide $\mathrm{Na}_{2} \mathrm{O}$ was the main reaction product. In Test $A B 2$, during which steam was added, aerosol consisted of sodium hydroxide with variable amounts of water of hydration and solution. The burn pan reaction product in this test contained approximately equal fractions of sodium monoxide and sodium hydroxide.

- The presence of steam apparently reduced the fraction of burned sodium that was aerosolized; fractions aerosolized were found to be 0.26 and 0.22 in Tests $A B 1$ and $A B 2$, respectively.

- Particle sizes measured with cascade impactors were in good agreement with sizes obtained from differential settiing measurements; therefore, particle fracturing in the impactor was minimal.

- The measured aerosol mass concentrations and particle sizes were in good agreement with predictions made with the HAA-3B code, using an alpha-epsilon $(\alpha \varepsilon)$ product of 0.2 . This $\alpha \varepsilon$ 
product is close to the value $(0.25)$ that was derived from smaller-scaled tests.

- Posttest predictions made with the HAA-3B code, using a source rate based on experimental measurements, were within 10\% agreement with test results in terms of aerosol leakage potential. The two pool-fire tests thus supported the validity of the HAA-3B code applications in dose evaluations of postulated sodium fire accidents.

- The HAARM-3 code gave predictions that agreed well with the experimental results and with the HAA-3B code.

- The SOFIRE-II code yielded predictions of burning rate, atmosphere temperature increase, and pressure increase that were somewhat higher than observed measurements; however, this code is sensitive to several input parameters--one of which is the sodium/oxygen mass ratio for the pool burning process. Using a smaller value of this parameter would have improved the fit with the experiments.

- Significant convection currents existed within the containment vessel during the pool-fire period. Anemometer measurements near the wall showed a maximum vertical velocity of $1.0 \pm 0.3 \mathrm{~m} / \mathrm{s}$. The vessel centerline velocity is estimated at ten times this value. These currents decreased after the pool fire was terminated but remained strong enough to keep the atmosphere well mixed throughout the 5-day test period, as shown by uniformity of particle size, particle suspended mass concentration, and oxygen concentration.

- Particle electric charge distribution measurements indicated that the dry particles in the normal atmosphere test ( $A B 1$ ) had a higher charge than the wet aerosol but that the net charge was close to zero in both tests. 
- The sodium oxidation rate averaged $\sim 38 \mathrm{~kg} \mathrm{Na} / \mathrm{hr} \mathrm{m}^{2}$, which is somewhat less than predicted by the SOFIRE-II code. 


\section{INTRODUCTION}

This report presents the results of two large-scale tests (ABI and AB2) of aerosol behavior related to sodium-cooled reactors. In both tests, sodium was burned in a $4.38-\mathrm{m}^{2}$ pool for one hour. Aerosol properties were measured during the fire period and for 50 hours following source termination. No engineered air cleaning features were employed, and aerosol depletion was caused solely by passive processes.

The aerosol likely to be formed during postulated accidents in sodium-cooled reactors has been the subject of considerable study at many laboratories throughout the world during the past decade. ${ }^{(1-10)}$ Reported work has encompassed theoretical treatments, computer modeling, and experimental measurements in vessels ranging in scale from small to intermediate. This report provides new information in two areas: vessel size and water vapor concentration.

Vessel height affects agglomeration time and probably the physical nature of the agglomerate particles. Prior data were limited to vessels $9 \mathrm{~m}$ or less in height, and the need for larger-scale experiments to clarify the effects of vessel size and shape on airborne concentration has been pointed out. (2) In addition, although many postulated accidents involve structures with concrete surfaces that release water vapor when heated, $(11,12)$ very few tests have been done with representative concentrations of water vapor. Water vapor adsorbed by aerosol particles may cause significant chemical and physical changes in the particles, thereby affecting their settling and leakage behavior.

The CSTF was originally constructed and operated to study containment and air cleaning systems under light water reactor (LWR) accident conditions, ${ }^{(13)}$ and is the largest test vessel available in the United States. The capability for generating sodium aerosols was added, and an experimental program is underway to develop and demonstrate air cleaning sytems under simulated conditions applicable to sodium-cooled reactors. (11) 
While the main purpose of the two pool-fire tests reported herein was to obtain baseline data applicable to future air cleaning tests, the test results also have provided an opportunity to assess the validity of existing aerosol codes. 


\section{TEST OBJECTIVES}

The primary objective of the test program was to characterize the properties and behavior of aerosol particles formed by sodium pool fires in a large containment vessel under dry and wet conditions where only passive transport processes (plateout and settling) operated. A secondary objective was to evaluate containment atmosphere temperature and pressure responses to large sodium pool fires. 


\section{EXPERIMENTAL FACILITY AND PROCEDURE}

\section{A. CSTF CONTAINMENT VESSEL}

The pool-fire tests described in this report were carried out in the CSTF containment vessel. This vessel, 20.4-m height and 7.62-m diameter, is pictured in Figure 1, which shows $250 \%$ of the vessel. The lower part of the CSTF is located within a concrete cell.

The test vessel was fabricated in accordance with ASME Section VIII Code (1962) with a design pressure of $0.517 \mathrm{MPa}$ at $160^{\circ} \mathrm{C}$. It is a carbon steel (SA-212-B) vessel with standard dished top and bottom heads. All interior surfaces are coated with modified phenolic paint. External surfaces are covered with a 25.4-mm layer of fiberglass insulation, which has a thermal conductivity of $0.0467 \mathrm{~W} / \mathrm{m}{ }^{\circ} \mathrm{C}$ at $100^{\circ} \mathrm{C}$. Additional construction details are provided in Table 1.

The test arrangement used in the pool-fire tests is shown schematically in Figure 2. As indicated, the vessel was equipped to contain a sodium pool fire of definite duration and provided various instrumentation and sampling equipment required to characterize the aerosol.

Prior to the test, sodium was heated to $600^{\circ} \mathrm{C}$ in a $1.7-\mathrm{m}^{3}$ vessel constructed of Type 304 stainless steel (SS). At time zero $\left(t_{0}\right)$ a valve was opened and argon pressure forced sodium through a $2-i n$. Schedule 40 pipe (52.5-mm ID) into a carbon steel pan centered near the bottom of the containment vessel. The burn pan, which was $0.36-\mathrm{m}$ deep and had a rectangular cross section $1.81 \mathrm{~m} \times 2.42 \mathrm{~m}$, rested on insulating firebrick and its sides were insulated. The pan's hinged, gasketed lid permitted termination of the aerosol source on command. 


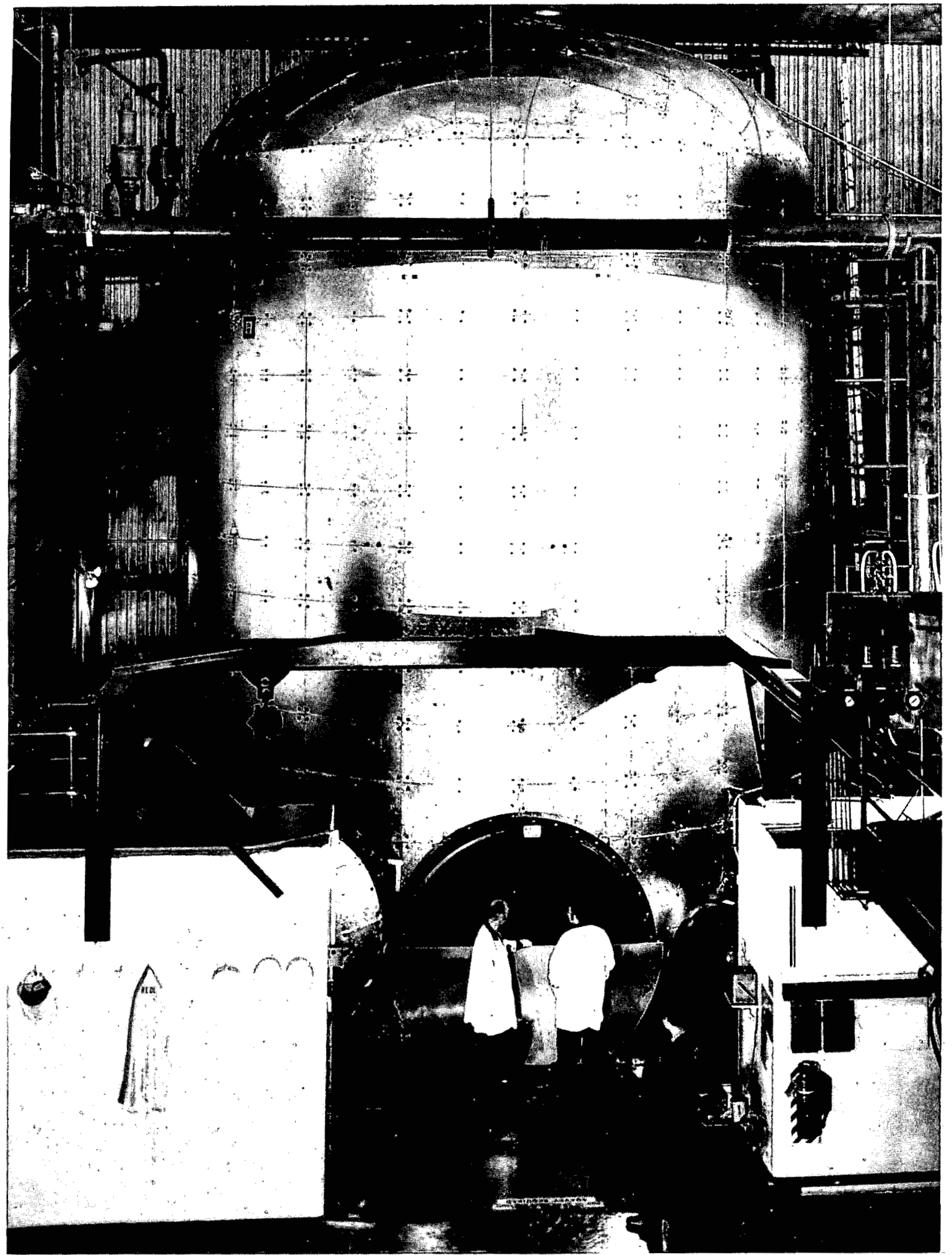

FIGURE 1. External View of CSTF Containment Vessel. (7610207-2CN) 
TABLE 1

H क

TEST CONDITIONS FOR CSTF TESTS AB1 AND AB2

CONTAINMENT VESSEL

Diameter ( $m$ )

Overall height $(\mathrm{m})$

Volume $\left(\mathrm{m}^{3}\right)$

Total horizontal surface $\left(\mathrm{m}^{2}\right)$

Shel1 surface $\left(\mathrm{m}^{2}\right)$

Total internal surface $\left(\mathrm{m}^{2}\right)$

Vesse 1 steel mass $(\mathrm{kg})$

Leakage rate (\% per day at 10 psig)

SODIUM SPILL

Mass sodium spilled $(\mathrm{kg})$

Sodium burn pan surface $\left(\mathrm{m}^{2}\right)$

Initial sodium temperature $\left({ }^{\circ} \mathrm{C}\right)$

Sodium fire duration (s)

Total sodium oxidized $(\mathrm{kg})$

STEAM ADDITION

Flow started (seconds after $t_{0}$ )

Flow stopped (seconds after $t_{0}$ )

Flow rate $(\mathrm{kg} / \mathrm{s})$

INITIAL CONTAINMENT ATMOSPHERE

Oxygen (vol\%)

Dew point $\left({ }^{\circ} \mathrm{C}\right)$

Temperature $\left({ }^{\circ} \mathrm{C}\right)$

Pressure (MPa, absolute)

CONTAINMENT ATMOSPHERE DURING TEST

Maximum temperature $\left({ }^{\circ} \mathrm{C}\right)$

Maximum pressure (MPa, absolute)

Final oxygen (vol\%)

Final dew point $\left({ }^{\circ} \mathrm{C}\right)$

\section{AEROSOL SOURCE}

Type

Source duration (s)

Average source rate - as sodium $(\mathrm{g} / \mathrm{s})$

Total aerosol release " as sodium (kg)

Fraction of oxidized sodium released
$A B 1$

$\begin{array}{cr}A B 1 & A B 2 \\ & \\ 7.62 & 7.62 \\ 20.3 & 20.3 \\ 850 & 850 \\ 88 & 88 \\ 520 & 520 \\ 1000 & 1000 \\ 103,000 & 103,000 \\ 2.0 & 2.6\end{array}$

410

4.4

600

3600

157

472

4.4

600

3600

175

- 960

- $\quad 4560$

$0 \quad 0.019$

19.8

10.0

26.5

0.125

20.9

7.6

20.5

0.128

91

0.142

96

14.7

$-40$

0.153

16.7

$-1.5$

$\mathrm{Na}$ Pool Fire $\mathrm{Na}$ Pool Fire 3600

11.1

39.9

0.255
3600

10.8

38.6

0.221 


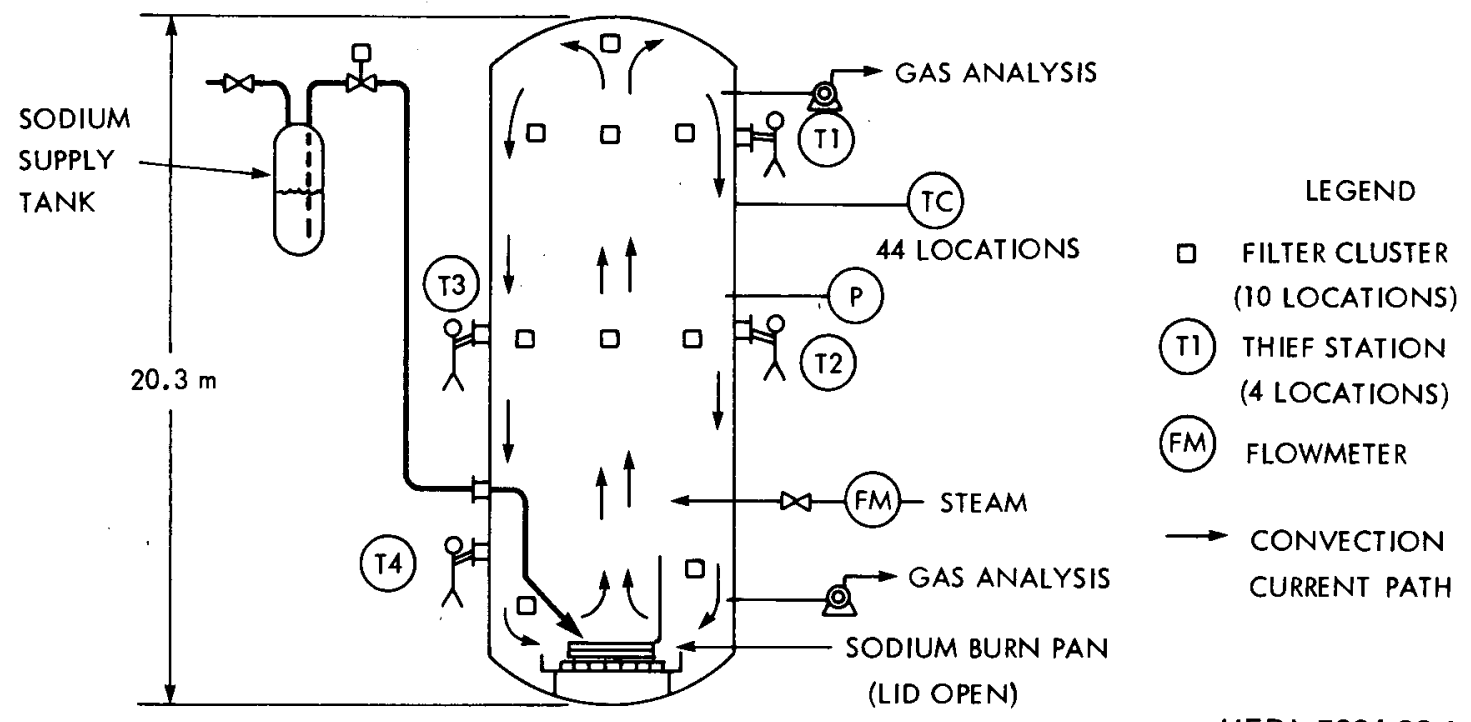

FIGURE 2. CSTF Aerosol Behavior Test Arrangement Used for Tests $A B 1$ and $A B 2$.

As indicated in Figure 2, aerosol samples were withdrawn from 10 internal positions and 4 wall air lock (thief station) locations. Temperature, pressure, oxygen, and hydrogen were monitored continuously, and grab samples of gas were taken for mass spectrometric analysis.

\section{B. EXPERIMENTAL INSTRUMENTATION}

\section{Temperature Measurement}

Temperature was measured at 44 locations both inside and outside the containment vessel. All thermocouples were chromel-alumel (Type K) with SS-sheathed leads--where exposed to the vessel atmosphere--and ungrounded junctions. Appendix E contains thermocouple locations.

\section{Pressure Measurement}

Gauge pressure within the vessel was measured continuously by a diaphragm-type transducer. Backup measurements were made by a Bourdon pressure gauge, which had a calibrated accuracy of $0.1 \%$ of full scale. 


\section{Aerosol Sampling Instruments}

A number of different sampling devices were used to determine the mass concentration and particle size distribution of aerosols in the two pool-fire tests.

\section{a. In-Vessel Cluster Samplers}

Filter samples were obtained at 10 locations in the CSTF vessel by means of clustered samplers, each of which contained 12 individual filter sample holders* separately connected to a vacuum 1 ine through 12 solenoid-operated valves. Figure 3 shows the bottom view of a cluster retrieved from the containment atmosphere following Test ABT.

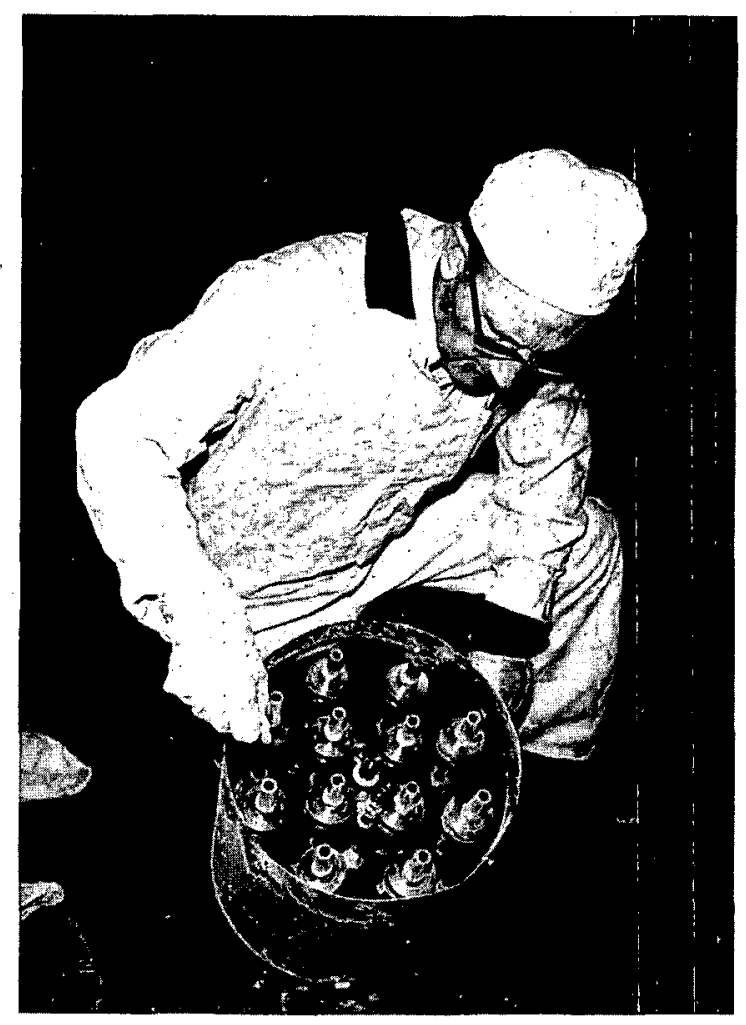

FIGURE 3. Bottom View of an In-Vessel Cluster Sampler.

(779932-9CN)

\footnotetext{
*Stainless steel holders with 47-mm diam filters, manufactured by Gelman Instrument Company, Catalog No. 2220, Ann Arbor, MI 48106.
} 
The cluster was suspended from a cable so that the inlet tube was pointing downward. This arrangement could give rise to a shadowing effect for large particles but the expected effect is sma11. Alternative orientations were considered but were rejected because of potential particle contamination under nonsampling periods.

At predetermined times, one solenoid valve in each of the 10 clusters was operated, thereby providing simultaneous samples at 10 spatial locations. Each cluster was attached to a tube that penetrated the containment vessel and led to a rotameter, manual flow control valve, and vacuum source. The samplers were located at various heights and radial positions, both of which are described in Appendix E.

One of the 12 samplers was used to obtain a background measurement for the clustered in-vessel samplers. Its controlling solenoid valve was not operated; otherwise, it was treated like the other 11 samplers.

The in-vessel filter samplers provided mass concentrations of airborne sodium at 10 vessel positions and 11 times.

\section{b. Through-the-wall Filter Samples}

In addition to the samples obtained from in-vessel samplers, filter samples were taken through air lock ports in the vessel wall. The air lock arrangement, pictured in Figure 4, permitted the filter samples to be inserted into the containment atmosphere without using a sample delivery line. Four locations on the vessel wall were equipped with air locks to permit sampler insertion and withdrawal. These stations are identified in Figure 2 as "thief" stations. Elevations and angular positions of these sampling stations are described in Table 2. 


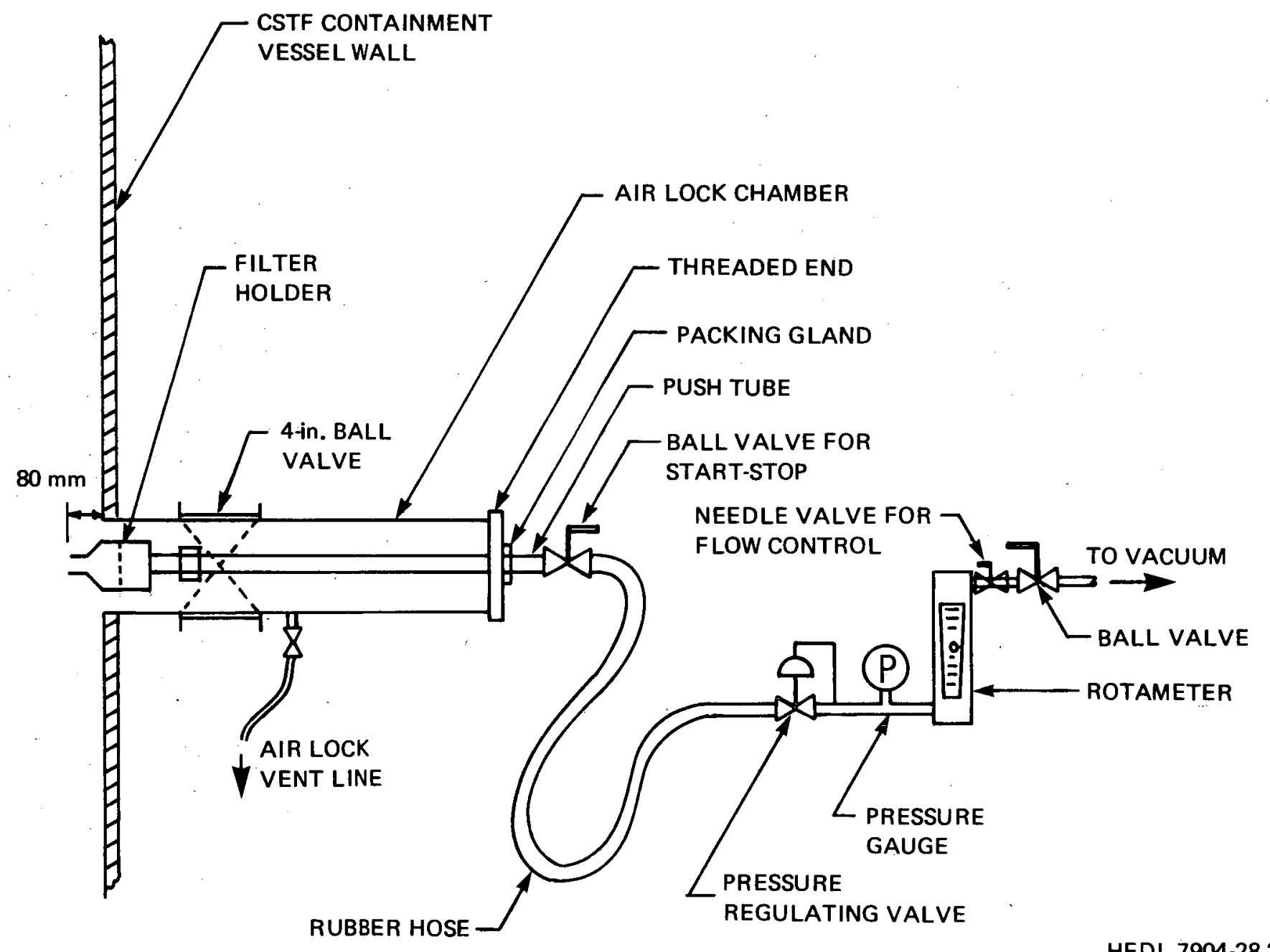

FIGURE 4. Through-the-Wall Sampling Stations Used in CSTF Aerosol Tests. 
TABLE 2

THROUGH-THE-WALL SAMPLING STATION LOCATIONS

\begin{tabular}{|c|c|c|}
\hline $\begin{array}{l}\text { Station } \\
\text { Number }\end{array}$ & $\begin{array}{c}\text { Elevation } \\
(\mathrm{m})\end{array}$ & $\begin{array}{l}\text { Azimuth }{ }^{(b)} \\
\text { (degrees) }\end{array}$ \\
\hline T-1 & +6.1 & 255 \\
\hline T-2 & +1.5 & 290 \\
\hline T-3 & +7.4 & 135 \\
\hline T-4 & -5.8 & 85 \\
\hline
\end{tabular}

(a) Elevation measured from lower edge of equipment door (bottom head of
vessel is at $-9.0 \mathrm{~m}$ ). (b) Angle measured clockwise from center of equipment door.

The filter holders inserted through the wall stations were identical to those used in the in-vessel samplers. Filter media were fiberglass (Gelman* Type $A / E)$ when the aerosol concentration was high. The fiberglass paper had a high loading capacity, which permitted reasonably long sampling periods, but contained $\sim 0.25 \mathrm{mg} \mathrm{Na}$, which reduced the accuracy of low concentration samples. When the airborne concentration was low, a membrane filter with a very low sodium background level (Gelman Acropor 3000) was used. A fluorocarbon fiber filter (Millipore** Mitex) was used to collect airborne particles for chemical analysis. A disassembled filter holder is pictured in Figure 5.

\section{c. Deposition Coupon Samples}

Differential deposition samples were obtained by inserting stainless steel coupons (51-mm diam) into the vessel atmosphere through the wall ports shown

*GeIman Instrument Company, Ann Arbor, MI 48106. **Millipore Filter Corporation, Bedford, MA. 


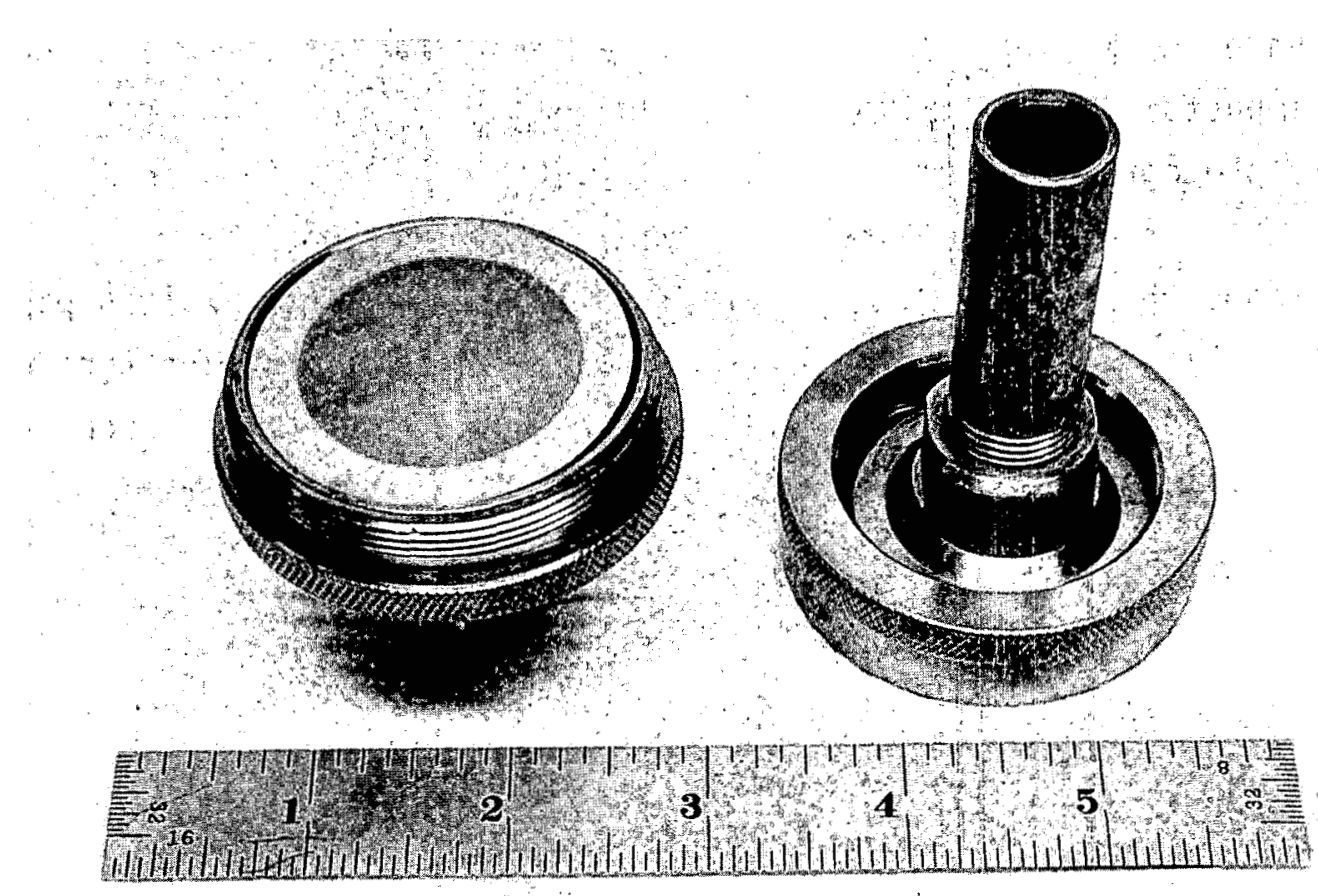

FIGURE 5. Filter Holder Used With In-Vessel Samplers and in Through-the-Wall Sample Withdrawal. (7803063-46)

in Figure 4. The rod used to insert the deposition coupons was long enough to expose their upper surfaces to the containment atmosphere at least $100 \mathrm{~mm}$ from the vessel wal1. Aerosol deposited on the upper surfaces of the coupons was subsequently removed with water and analyzed for sodium content. Based on exposure time and airborne sodium concentration, a deposition velocity (gravity settling velocity) could be calculated.

\section{d. Cascade Impactor Samplers}

Particle size distributions were obtained by cascade impactors inserted into the vessel atmosphere through wall stations $T-1$ and $T-4$. As indicated in Table 2, these two locations represented extremes in elevation and azimuth.

Two types of multi-jet impactors were used to help evaluate biases that might be associated with particular impactor designs. An 8-stage circular jet 
impactor (Andersen Mark III High Temperature Sampler*) and a 6-stage rectangular jet impactor (Sierra Model 226 Stack Sampler**) were both used. Figures 6 and 7 are photographs of these impactors, which are described in Appendix B.

The photographs show the stages individually covered with fiberglass paper. Samples taken with and without the glass fiber collection surface agreed very closely, hence the paper mat was used in all samples to minimize reentrainment and to simplify deposit analysis.

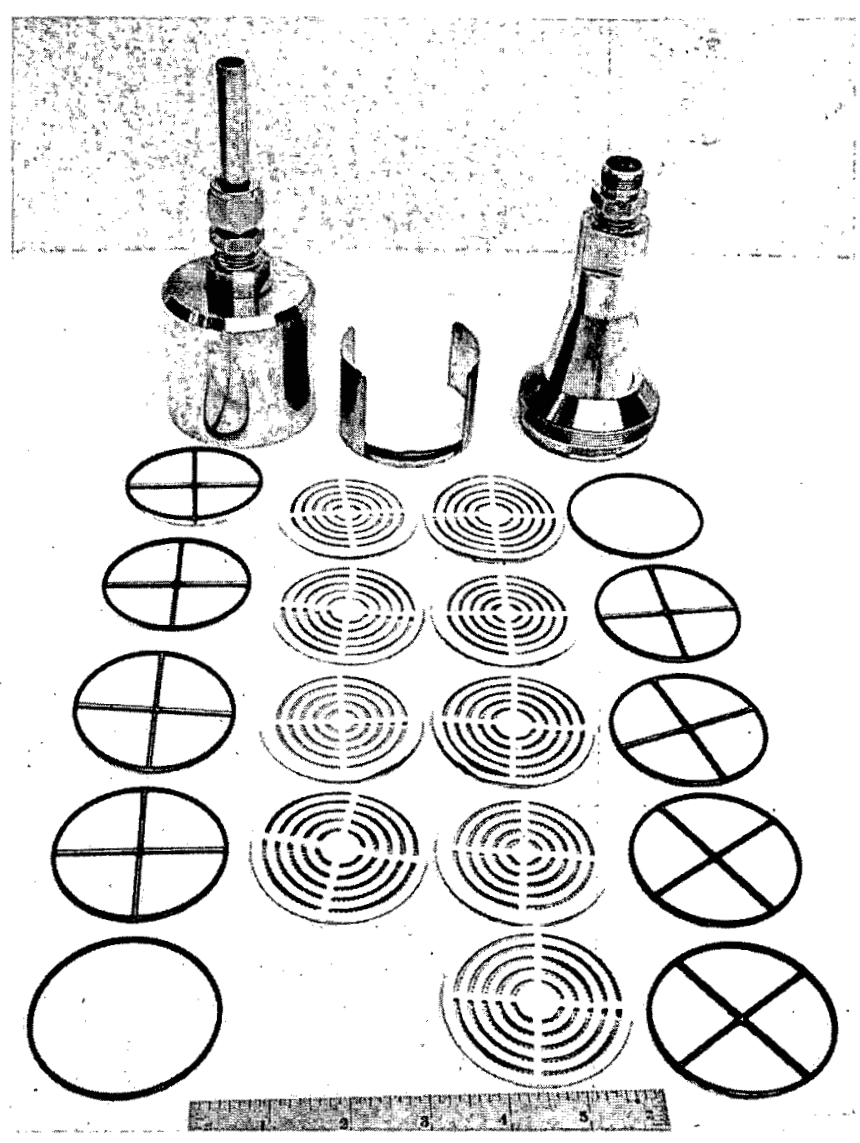

FIGURE 6. Circular Jet Impactor. (7803063-34)

*Manufactured by Adersen 2000, Inc., Atianta, GA.

**Manufactured by Sierra Instrument Company, Carmel Valley, CA. 


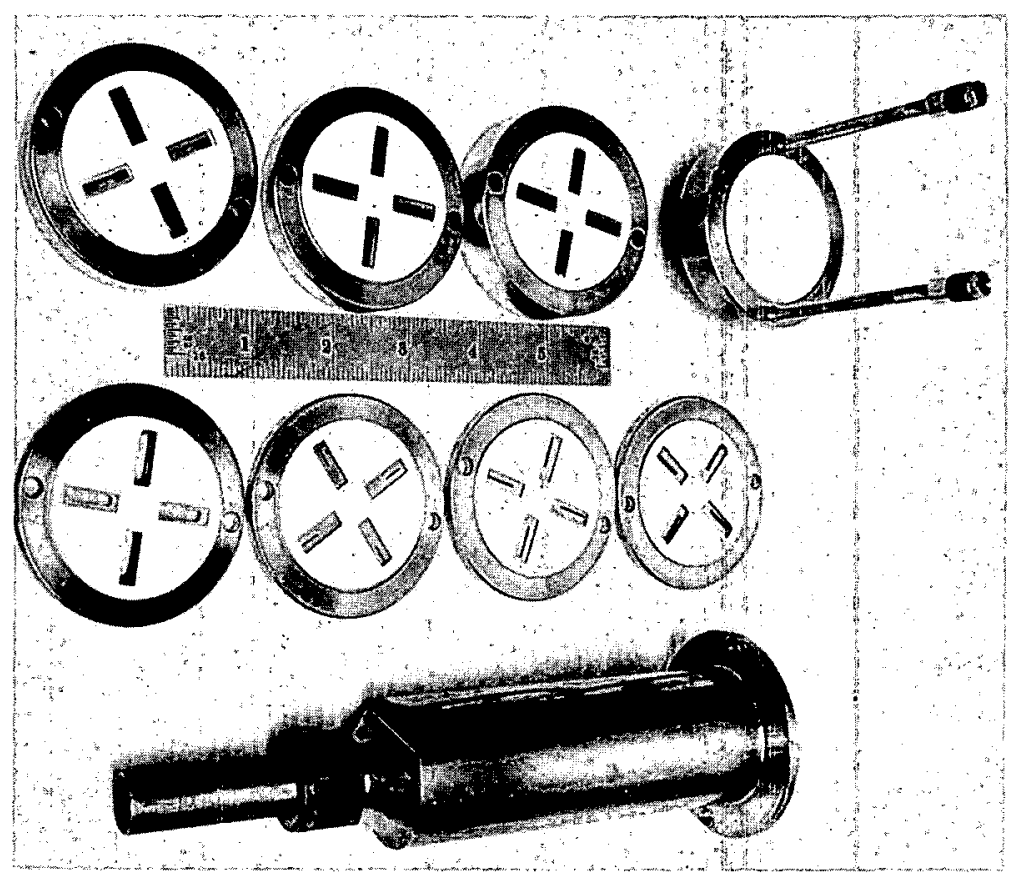

FIGURE 7. Rectangular Jet Impactor. (7803063-32)

When a sample was withdrawn from the containment atmosphere, the impactor was inserted into the vessel far enough so that the inlet was at least $100 \mathrm{~mm}$ from the vesse1 wal1. Samples were withdrawn from the high and low positions (T-1 and $\mathrm{T}-4$ ) simultaneously to permit comparisons on a spatial basis.

\section{e. Gravity Settling Sampler}

A gravity settling chamber was built to withdraw particles under low shear conditions. Large agglomerate particles could theoretically be fractured in the cascade impactors, and the horizontal elutriator was used to help evaluate whether particle breakup in the impactors was significant.

The sampler consisted of a vertical array of 16 rectangular flow channels, each of which was $2.49 \mathrm{~mm}$ high, $50.4 \mathrm{~mm}$ wide, and $203 \mathrm{~mm}$ long. The unit was backed up by a high efficiency filter so that the total mass of aerosol entering the sampler could be determined. The gravity settling sampler is pictured 


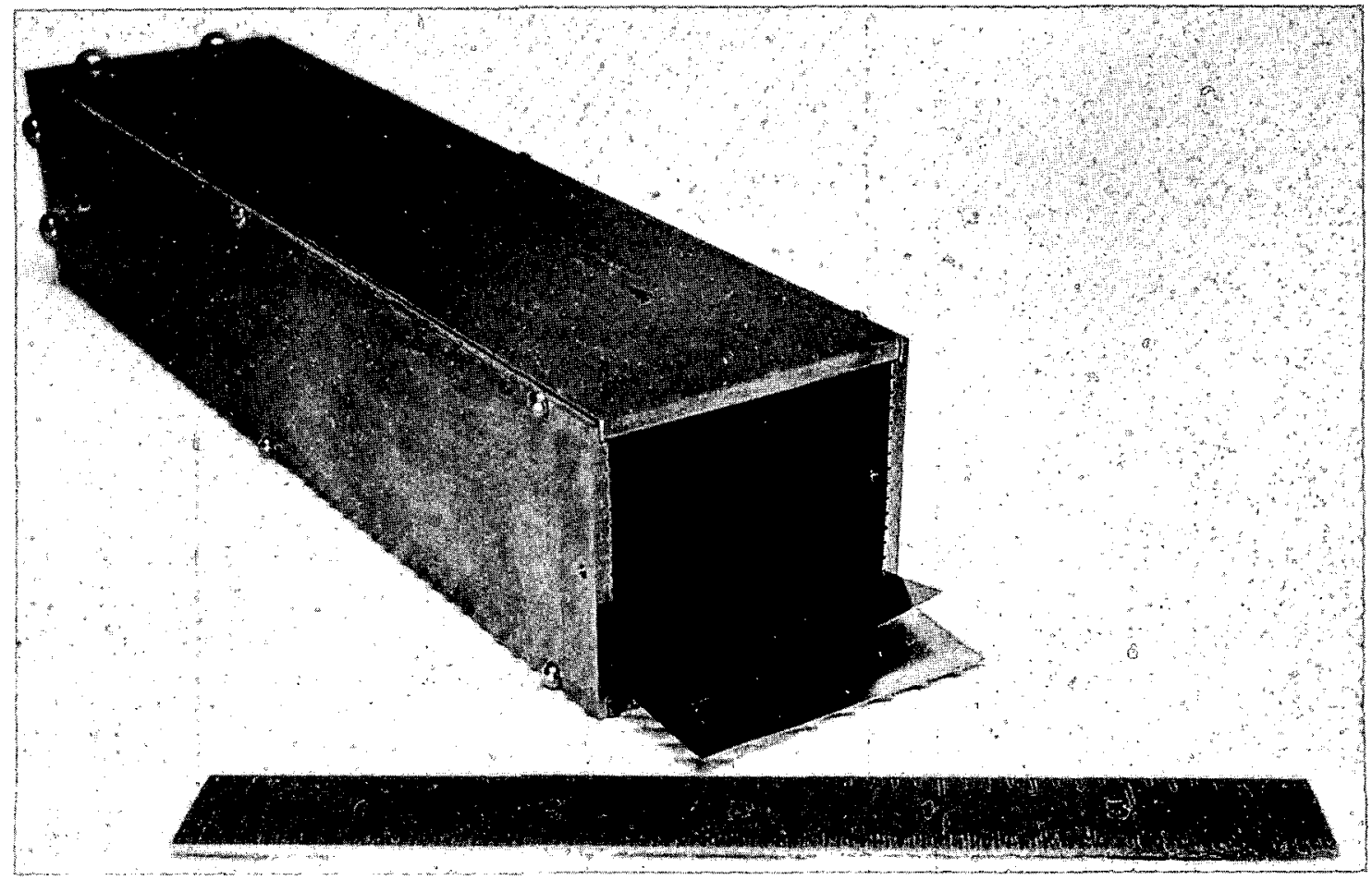

FIGURE 8. Gravity Settling Sampler. (7803063-4)

in Figure 8. As the photograph shows, the horizontal flow channels were formed from thin stainless steel sheets. After a sample was withdrawn, the sheets were cut into transverse segments and the deposit was removed in a water wash. Particle size distribution was computed by iteration until the observed deposition profile fit one computed on the basis of laminar flow.

\section{f. Electrical Mobility Analyzer}

The level of electrical charging of aerosol particles was measured by a parallel plate mobility analyzer. While the design of this apparatus was based on a paper by Gillespie and Langstroth, ${ }^{(14)}$ the device closely resembled one described by Megaw and Wells. (15)

Aerosol was introduced between aluminum plates as a thin rectangular stream; clean sheath air separated the introduced particles from the plates. As the 


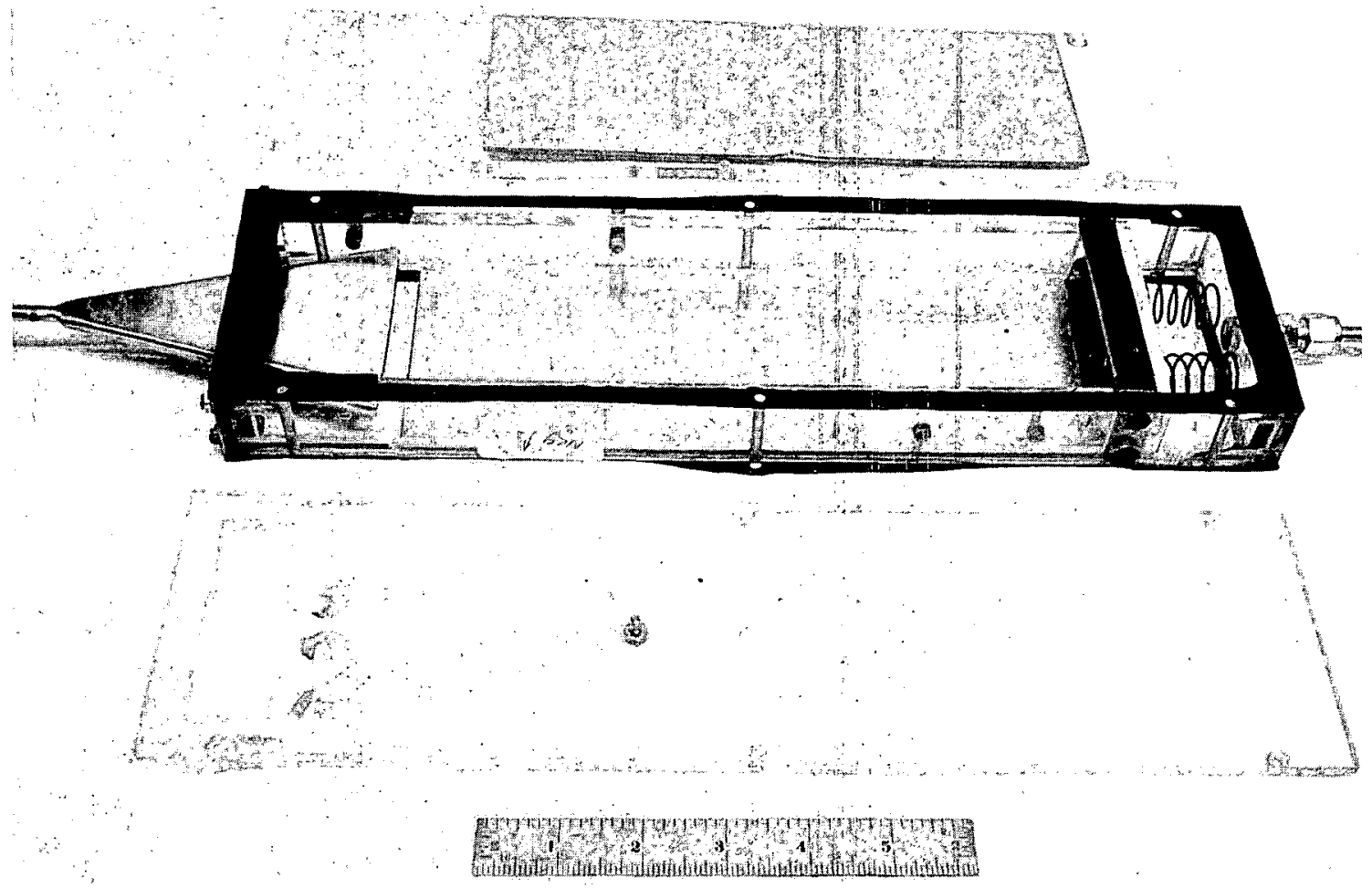

FIGURE 9. Particle Electrical Mobility Analyzer. (7803063-38)

aerosol flowed between the planes, particles were deflected toward the oppositely charged plate with a velocity dependent on mobility. The mobility spectrum was determined by a lengthwise analysis of collected particle mass. Particles not precipitated were collected on an outlet filter that was also analyzed for particle mass. The mobility analyzer is shown in Figure 9.

\section{g. Electron Microscope Grid Sampler}

Electron microscope grids covered with carbon film were used to collect particle samples by grayity settling. The grids were mounted on a rod that was inserted into the vessel through a sliding gland.

The grid support rod was encased in a tube and sealed by 0 -rings. The 0-ring seals permitted withdrawal of the grids from the vessel without exposing them 


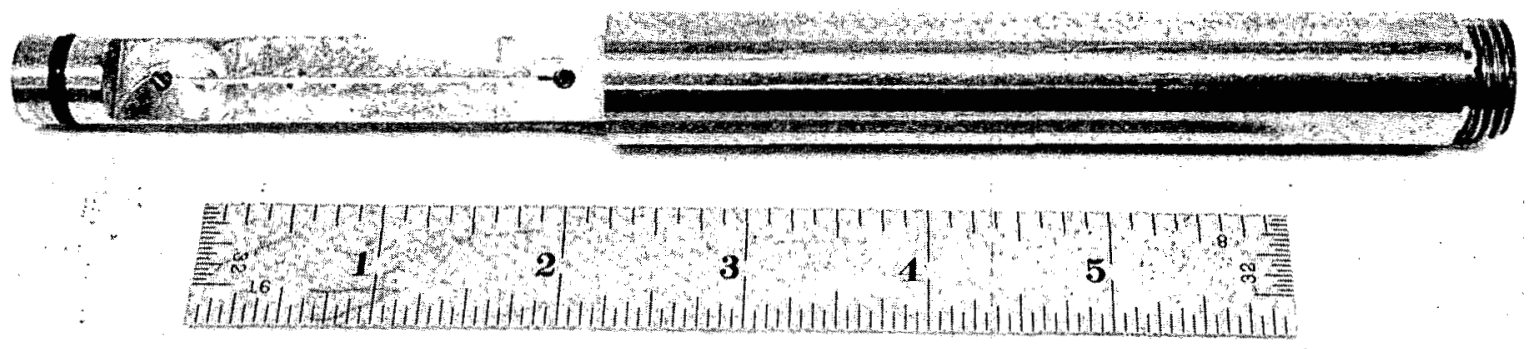

FIGURE 10. Exposure S1ide Used to Obtain Particle Samples for Electron Microscopy. (7803063-44)

to any other atmosphere. The 0-ring seal was not broken until the holder was placed within a controlled atmosphere glove box, thus avoiding changes in physical shape of the hygroscopic sodium oxide particles due to exposure to a humid atmosphere. Figure 10 shows the electron microscope grid holder.

\section{Data Acquisition}

Al1 on-line instruments with electronic outputs were connected in parallel to a 100-channel digital data logger and to strip-chart recorders. The data logger output was onto paper and magnetic tape.

Most of the aerosol sampling was performed manually by trained operators who recorded the appropriate data on log sheets.

\section{EXPERIMENTAL PROCEDURE}

In each of the tests the following procedure was used:

- Install and calibrate the equipment and instrumentation,

- Dry the vessel to a constant, normal humidity, 
- Seal the vessel so that it was essentially leak-tight, and

- Heat the sodium to $600^{\circ} \mathrm{C}$ in the auxiliary sodium tank.

At a time defined as time zero $\left(t_{0}\right)$ a valve was opened and the sodium flowed into the burn pan through the electrically heated delivery line. Figure 11 is a photograph taken through a viewing window near the bottom of the vessel. A dense plume of aerosol particles formed immediately and swirled upward until it was dispersed throughout the containment vessel. The sodium flow lasted 80 seconds; then the sodium supply system was isolated from the containment vessel.

The pool fire was allowed to burn for one hour; then the burn pan lid was lowered to extinguish the fire. This action terminated the aerosol source and allowed meaningful aerosol depletion measurements to be made beginning one hour after sodium spil1.

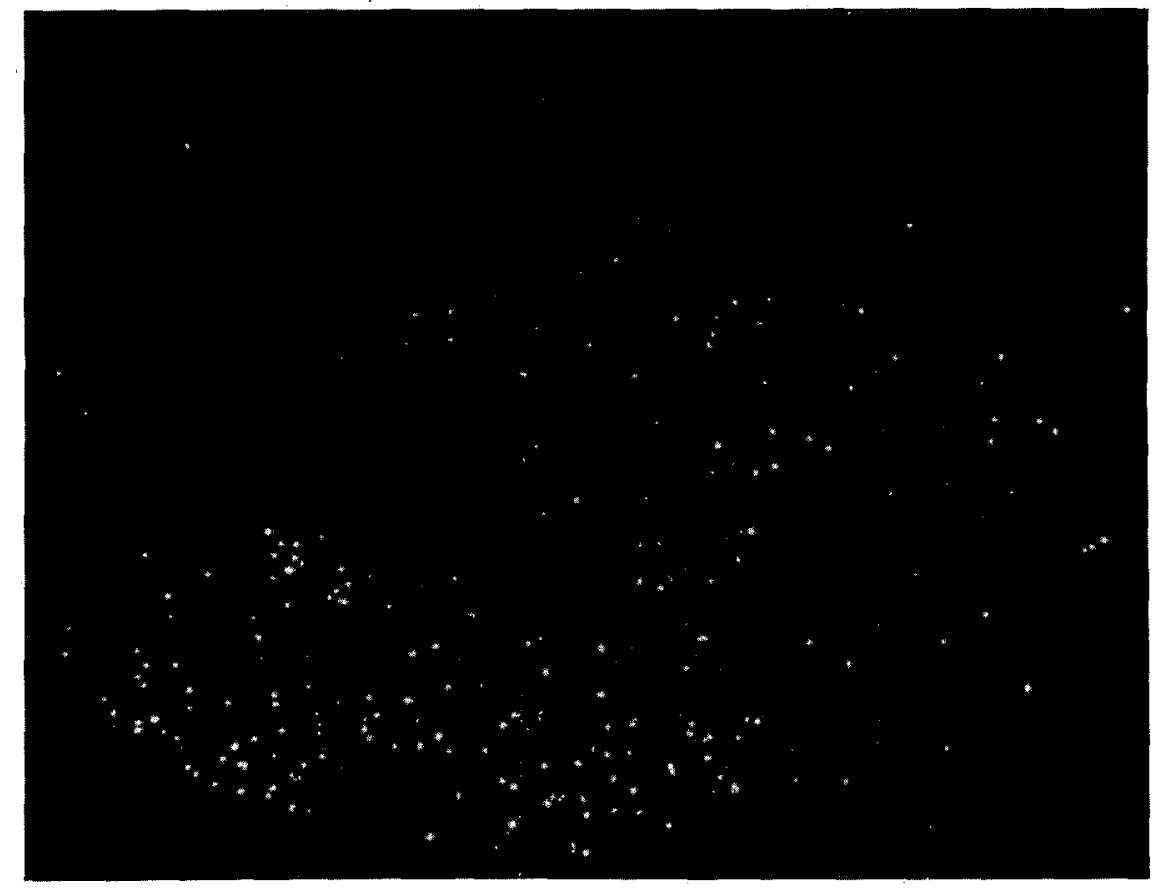

FIGURE 11. View of Sodium Spiliing Into ABT Burn Pan 10 Seconds After Start of Spi11. (781106-4CN) 
The experimental aerosol measurements were made with decreasing frequency over a 5-day period; then a ventilation fan was started to prepare for personnel entry, and the internal samplers and integral deposition trays were retrieved. (Figure 12 is a view of the vessel interior at the time of first entry during $A B 1$.$) The burn pan with the partially oxidized sodium was removed, weighed,$ and its contents sampled. A patch of vertical wall surface was decontaminated and the washings were analyzed for sodium content. The vessel was then washed by a series of water sprays, first the bottom head, next the vertical walls, and last the top head. Finally, steam was injected for several days to clean all crevices by condensation. The volume of each wash was measured and analyzed for sodium concentration to enable a sodium mass balance to be made.

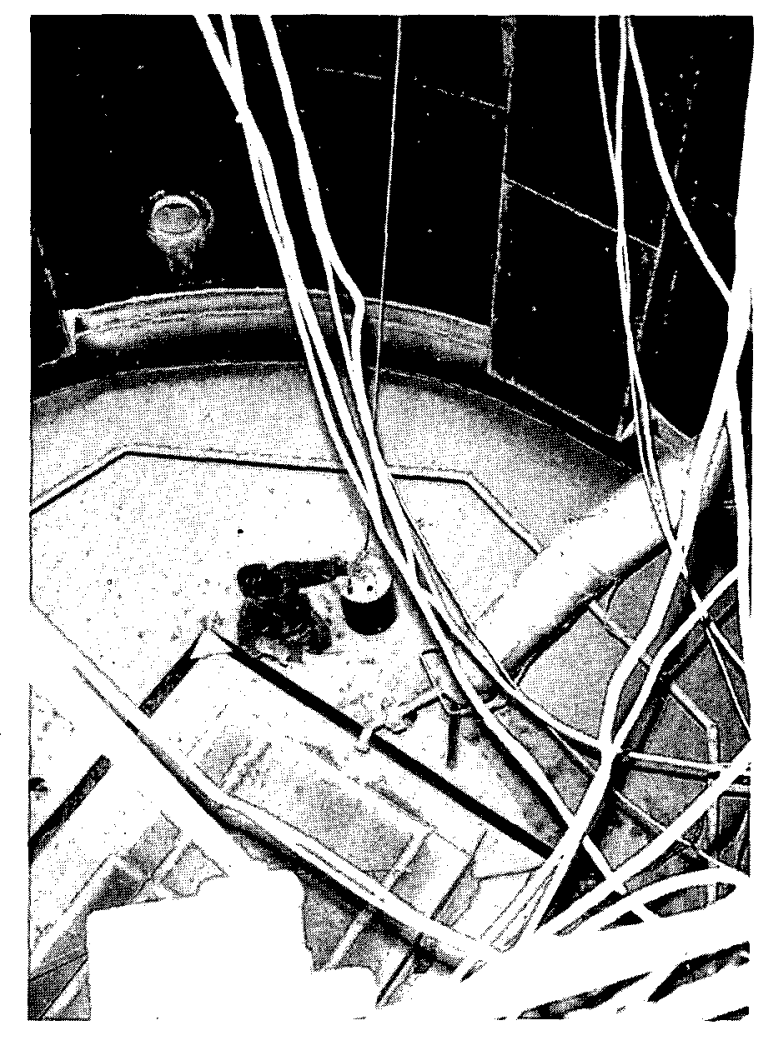

FIGURE 12. View of Vessel Interior Showing Deposited Aerosol - Test ABT. (779932-24CN) 


\section{CHEMICAL ANALYSIS}

The filter media from the aerosol samplers were leached with demineralized water and analyzed for sodium by acid titrimetry or emission spectrometry. The two methods were compared and found to agree within 5\%. Appropriate blank corrections were made to account for background sodium in the filter media and demineralized water. The blank corrections were negligible except for some of the cascade impactor stages where corrections up to $100 \%$ of the deposited sample were required.

The chemical forms of the suspended and deposited aerosol were analyzed by a combination of methods:

- X-ray diffraction provided information on crystalline forms $\left(\mathrm{Na}_{2} \mathrm{O}, \mathrm{NaOH}\right.$, and hydrates).

- Sodium peroxide was determined by reaction with iodide ions, giving free iodine which was then titrated with thiosulfate.

- Sodium carbonate was determined by potentiometric acid titration. Sodium carbonate gives inflections at known pHs. For samples with a small fraction of carbonate $(<5 \%)$, the $\mathrm{CO}_{2}$ was 7 iberated with acid and the quantity of $\mathrm{CO}_{2}$ released was measured by gas chromatography.

- Sodium hydride was determined by measuring the quantity of $\mathrm{H}_{2}$ released by gas chromatography when the sample was added to water. If metallic sodium was present, hydrogen was released from both sources.

- The total sodium content was determined by flame emission spectrometry of a water solution.

- A material balance was performed to account for all forms detected.

of course, it was essential to minimize chemical changes due to sampling and handling. It is believed that this was accomplished by collecting the aerosol 
on Teflon membrane filters, sealing the collecting sampler, and performing the analyses in an argon atmosphere glove box where necessary.

A17 cascade impactor collection papers were analyzed for sodium by emission spectrometry of water leaches.

\section{E. TEST CONDITIONS}

Tests $A B 1$ and $A B 2$ were performed with essentially the same initial conditions, but in test $A B 2$ steam was injected at a rate equivalent to the release of water vapor from $210-30 \mathrm{~m}^{2}$ of hot concrete. (12) A1though the aerosol and. steam release rates and duration were arbitrary, they are within the range of accident conditions postulated in Liquid Metal Fast Breeder Reactors (LMFBR) safety analyses.

The initial containment atmosphere was air at normal temperature and humidity. Other test conditions were listed in Table 1 (page 11). 


\section{EXPERIMENTAL RESULTS}

\section{A. VISUAL OBSERVATIONS}

The visibility within the vessel was estimated by observations of visual range made through two viewing windows. The results, shown in Figure 13, are in good agreement with those reported by Reist and Hinds ${ }^{(16)}$ for sodium burning in a $90-\mathrm{m}^{3}$ cell.

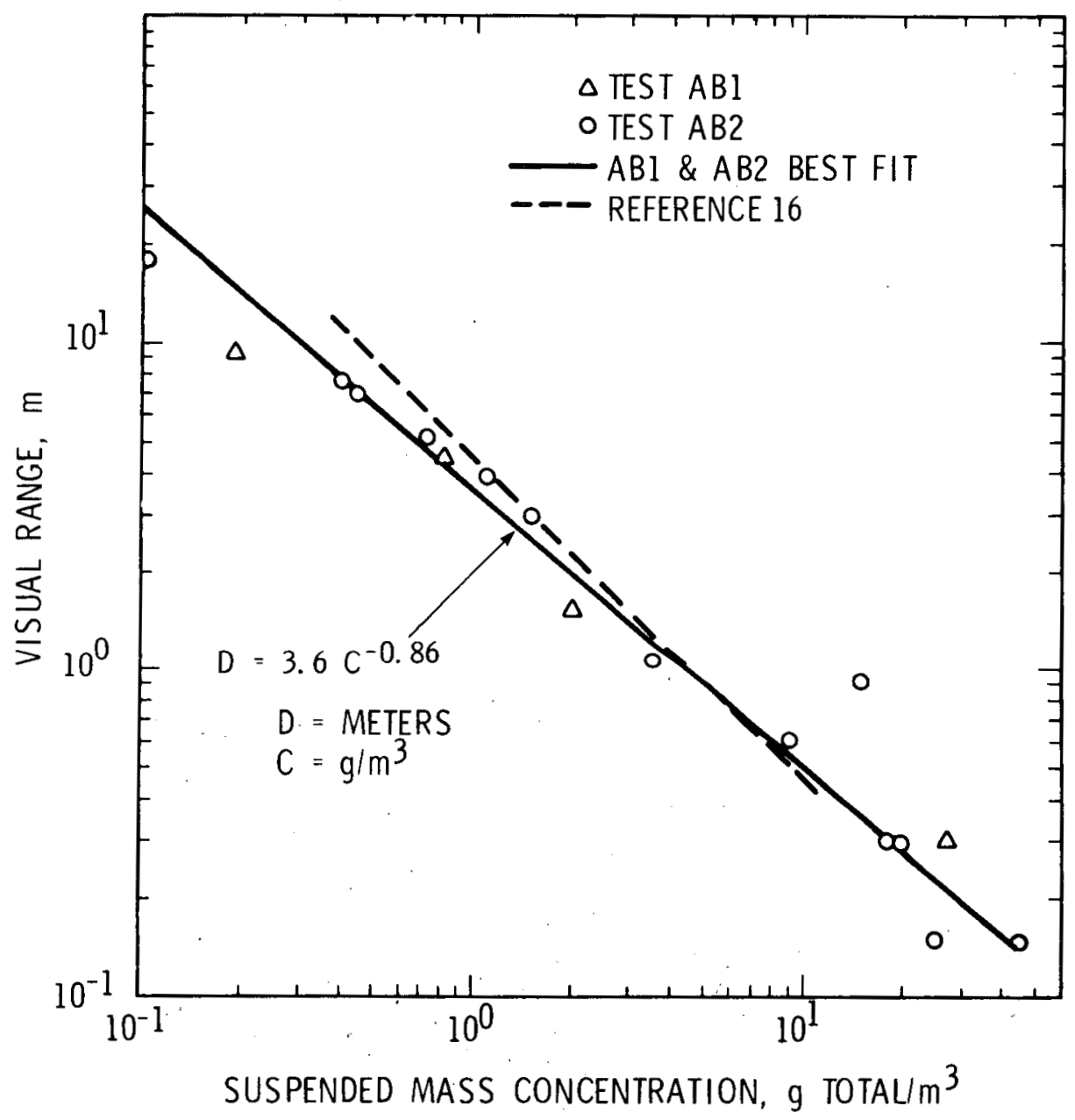

HEDL 7807-036.11

FIGURE 13. Visual Range in a Closed Vessel During a Sodium Pool Fire. 


\section{B. CONTAINMENT ATMOSPHERE RESPONSE}

The atmosphere within the containment vessel was reasonably well mixed at all times excluding, of course, the region near the surface of the sodium pool and in the plume where mixing occurred. This conclusion was reached by noting that the standard deviation from the mean bulk gas temperature was $<5 \%$ of the mean and that the suspended mass concentration at 10 locations agreed within $\pm 10 \%$ during the sodium fire period and within $\pm 40 \%$ at long times. The gas composition at two elevations $12 \mathrm{~m}$ apart also agreed closely. The oxygen concentration decreased by $5.1 \%$ in $A B 1$ and by $4.2 \%$ in $A B 2$. The containment temperature and pressure are plotted in Figures 14 and 15 for tests $A B 1$ and $A B 2$, respectively. Tabular data on temperature and pressure are presented in Appendix F.

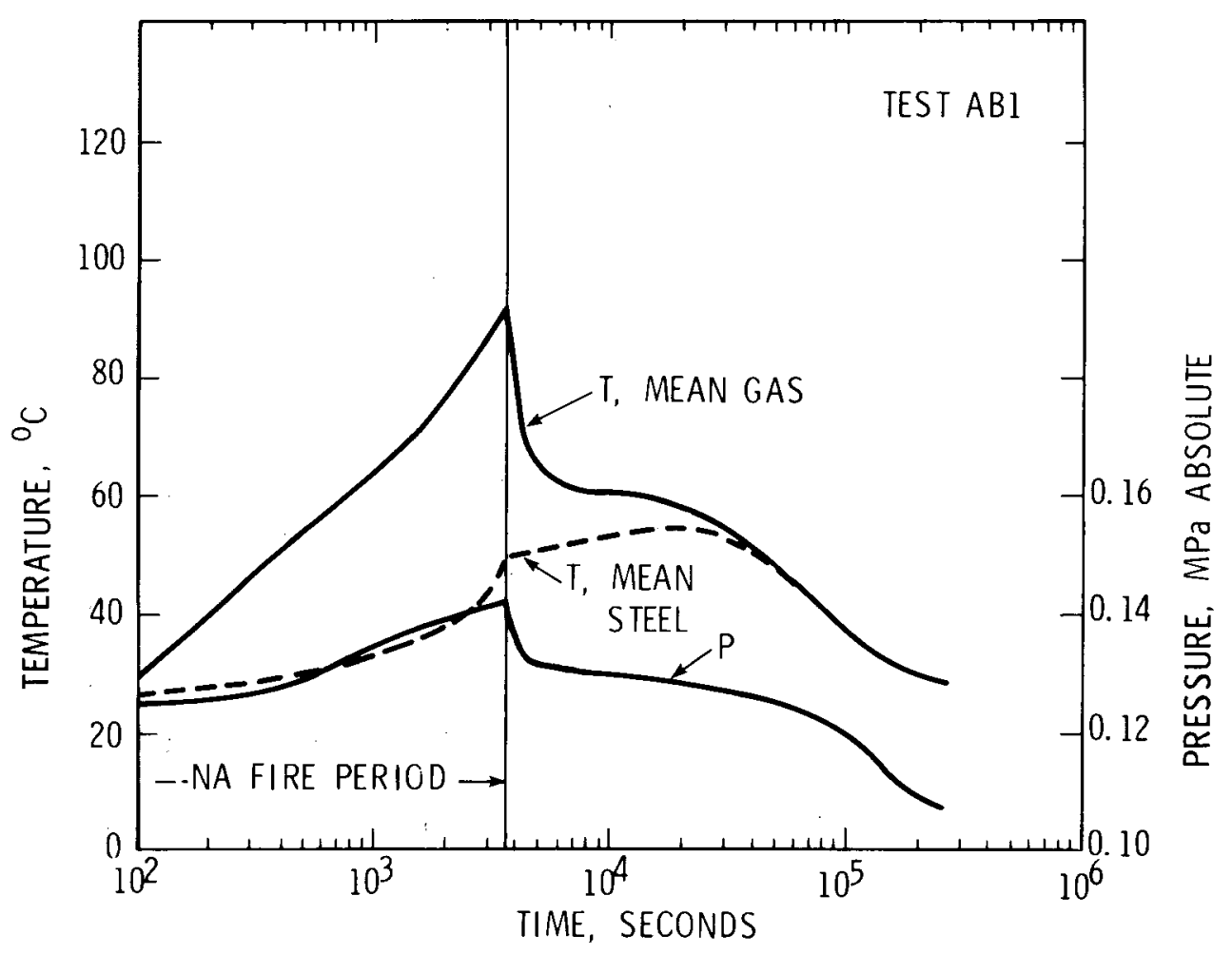

HEDL 7807-036.13

FIGURE 14. Containment Temperature and Pressure - Test AB1. 


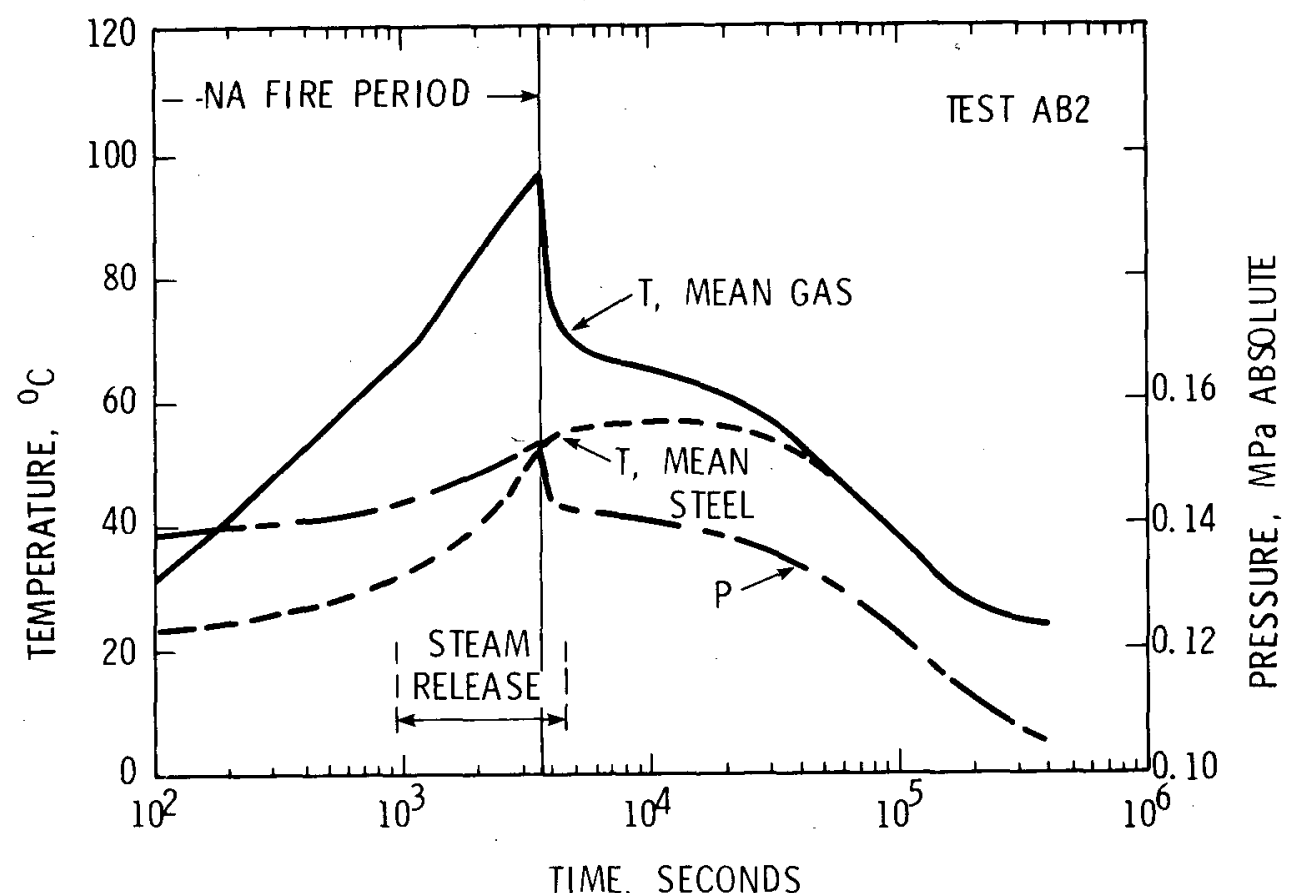

HEDL 7807-036.12

FIGURE 15. Containment Temperature and Pressure - Test AB2.

An attempt was made to measure the convection current velocity near the wall by means of a thermopile-type anemometer* inserted near the vessel midelevation. A maximum vertical velocity of $1.0 \pm 0.3 \mathrm{~m} / \mathrm{s}$ was measured in both tests at a distance of $20-50 \mathrm{~mm}$ from the wall. The highest velocities occurred 220 min after the spill in Test $A B 1$ and near the end of the sodium fire period during the steam release Test $A B 2$. Difficulty was experienced in making this measurement due to deposition of aerosol on the anemometer probe. Very frequent cleaning was required.

*Hastings Air-Meter, Model AB-27, manufactured by Hastings-Raydist, Hampton, VA. 


\section{AEROSOL SOURCE TERM}

The mass of sodium aerosolized was computed from analyses of water washes of vessel surfaces following the test. Results are presented in Table 3.

TABLE 3

SODIUM OXIDATION AND AEROSOL RELEASE

\begin{tabular}{|c|c|c|}
\hline & $\begin{array}{l}\text { Test } A B 1 \\
\text { (dry) }\end{array}$ & $\begin{array}{l}\text { Test } A B 2 \\
\text { (wet) }\end{array}$ \\
\hline Mass of sodium reacted $(\mathrm{kg})$ & 156.5 & 174.8 \\
\hline Average oxidation rate $\left(\mathrm{kg} \mathrm{Na} / \mathrm{hr} \mathrm{m}^{2}\right)$ & 35.7 & 39.9 \\
\hline Total aerosol mass released $(\mathrm{kg} \mathrm{Na})$ & 39.9 & 38.6 \\
\hline Average aerosol release rate $\left(\mathrm{kg} \mathrm{Na} / \mathrm{hr} \mathrm{m}^{2}\right)$ & 9.11 & 8.81 \\
\hline Average aerosol mass source $(\mathrm{kg} \mathrm{Na} / \mathrm{s})$ & 0.0111 & 0.0107 \\
\hline $\begin{array}{l}\text { Fraction of oxidized } \mathrm{Na} \text { released as } \\
\text { aerosol }\end{array}$ & 0.255 & 0.221 \\
\hline
\end{tabular}

The sodium oxidation rate was somewhat higher in the wet test than in the dry test $\left(39.9 \mathrm{~kg} \mathrm{Na} / \mathrm{hr} \mathrm{m}^{2}\right.$ versus $35.7 \mathrm{~kg} \mathrm{Na} / \mathrm{hr} \mathrm{m}^{2}$ ), suggesting that the presence of steam enhanced the burning rate. On the other hand, the mass of sodium aerosolized was quite similar for the two tests; thus, it appears that water vapor reacted with liquid sodium at the surface of the pool, leading to a faster overall combustion rate but without aerosolizing additional sodium.

Sodium recovery by selective posttest washing of the vessel surfaces showed that $\sim 7.3 \%$ of the aerosol deposited on vertical surfaces, while $92.7 \%$ settled on horizontal surfaces in each test. All horizontal surfaces were effective for collecting aerosol by settling, even surfaces sheltered by overhanding ledges and platforms. 


\section{AEROSOL CHEMICAL FORM}

Samples of the suspended aerosol were taken on fluorocarbon membrane filters and protected from laboratory air until analyzed for chemical composition as described in Section IV.D (page 25). The chemical form of the aerosol in Test $A B T$ is listed in Table 4 for several times during the test and for the composite floor deposit. The chemical composition changed continually during the test as reactions occurred with the $\mathrm{O}_{2}, \mathrm{H}_{2} \mathrm{O}$, and $\mathrm{CO}_{2}$ in the atmosphere. Shortly after the sodium spill, the aerosol was predominantiy $\mathrm{NaOH}$, formed by reaction of sodium oxide aerosol particles with the ambient humidity in the atmosphere. The initial $10^{\circ} \mathrm{C}$ dew point atmosphere in Test $A B 1$ contained 9.0 $\mathrm{kg}$ of water vapor--sufficient to convert half of the released sodium to $\mathrm{NaOH}$. In Test $A B 2$ the aerosol was completely converted to $\mathrm{NaOH}$ with excess water of hydration and solution. The average composition of the $A B 2$ aerosol was equivalent to a $60 \mathrm{wt} \%$ solution of $\mathrm{NaOH}$.

\section{TABLE 4}

AEROSOL CHEMICAL ANALYSIS - TEST AB1

\begin{tabular}{|c|c|c|c|c|c|c|c|c|c|}
\hline & \multicolumn{9}{|c|}{ Mass Fraction } \\
\hline & \multicolumn{9}{|c|}{ Suspended Aerosol $(a)$} \\
\hline & $\mathrm{Na}_{2} \mathrm{O}_{2}$ & $\mathrm{Na}_{2} \mathrm{CO}_{3}$ & $\mathrm{NaH}$ & $\mathrm{NaOH}$ & $\mathrm{H}_{2} \mathrm{O}$ & Total & Total $\mathrm{Na}$ & Total $\mathrm{H}$ & Total C \\
\hline $\begin{array}{l}\text { Sample } S 1 \\
t=16 \mathrm{~min}\end{array}$ & 0.150 & 0.029 & 0.0001 & 0.821 & 0.0 & 1.0000 & 0.573 & 0.0205 & 0.0033 \\
\hline $\begin{array}{l}\text { Sample s2 } \\
t=46 \text { min }\end{array}$ & 0.560 & 0.004 & 0.007 & 0.429 & 0.0 & 1.0000 & 0.585 & 0.011 & 0.0005 \\
\hline $\begin{array}{l}\text { Sample S3 } \\
t=190 \mathrm{~min}\end{array}$ & 0.430 & 0.018 & 0.0011 & 0.479 & 0.072 & 1.0000 & 0.538 & 0.020 & 0.0021 \\
\hline $\begin{array}{l}\text { Sample S4 } \\
t=610 \mathrm{~min}\end{array}$ & 0.350 & 0.061 & 0.011 & 0.421 & 0.097 & 1.0000 & 0.519 & 0.023 & 0.0069 \\
\hline $\begin{array}{l}\text { Composite } \\
\text { Sample }{ }^{(b)} \\
t=5 \text { days }\end{array}$ & 0.273 & 0.009 & 0.0008 & 0.670 & 0.047 & 1.0000 & 0.551 & 0.022 & 0.0011 \\
\hline
\end{tabular}


Approximately 75 filter papers taken from four locations during each test were protected from laboratory air until weighed to obtain total mass. The samples were then analyzed for sodium content and the mass fraction of sodium in the suspended aerosol was calculated and plotted as a funtion of time (see Figure 16). The effect of reactions with the atmosphere is displayed clearly. Analysis for only sodium could lead to significant errors in total mass.

A 2-g sample of the composite settled dry aerosol was exposed to the laboratory air (35\% relative humidity) and its weight and volume were measured as a function of time. Within about 30 hours the weight had doubled and gas bubbles had formed. The color changed from yellow-tan to white. The bulk volume increased by a factor of 215 due to the presence of the gas bubbles. Continued exposure to room air caused the sample to lose weight and form a hard crust of sodium carbonate.

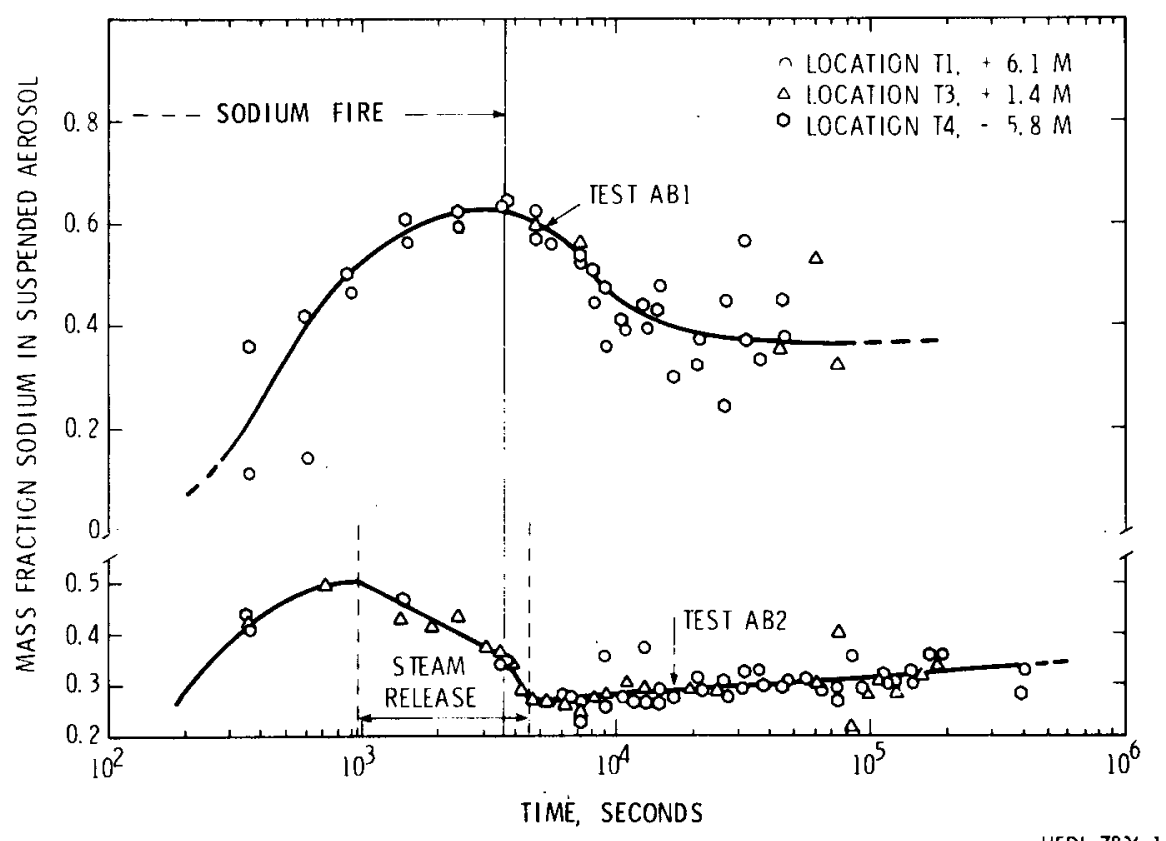

HEDL $78006-14.6$

FIGURE 16. Mass Fraction of Sodium in Suspended Aerosol. 


\section{E. SUSPENDED MASS CONCENTRATION}

The concentrations of suspended mass at various times are listed in Tables 5 and 6 for Tests $A B 1$ and $A B 2$, respectively. The figures in the tables are mean values of samples taken concurrently at four locations from high, low, and central regions in the containment atmosphere. The standard deviation from the mean is also shown. Individual measurements are believed accurate to within $\pm 15 \%$. The concentrations are reported in two ways: as total mass and as sodium. The data of Tables 5 and 6 are plotted as functions of time in Figure 17 and 18 for total mass. The maximum concentrations of suspended sodium were 15 and $12 \mathrm{~g} / \mathrm{m}^{3}$ for Tests $A B 1$ and $A B 2$, respectively. The maximum concentrations of total mass were 22 and $34 \mathrm{~g} / \mathrm{m}^{3}$.

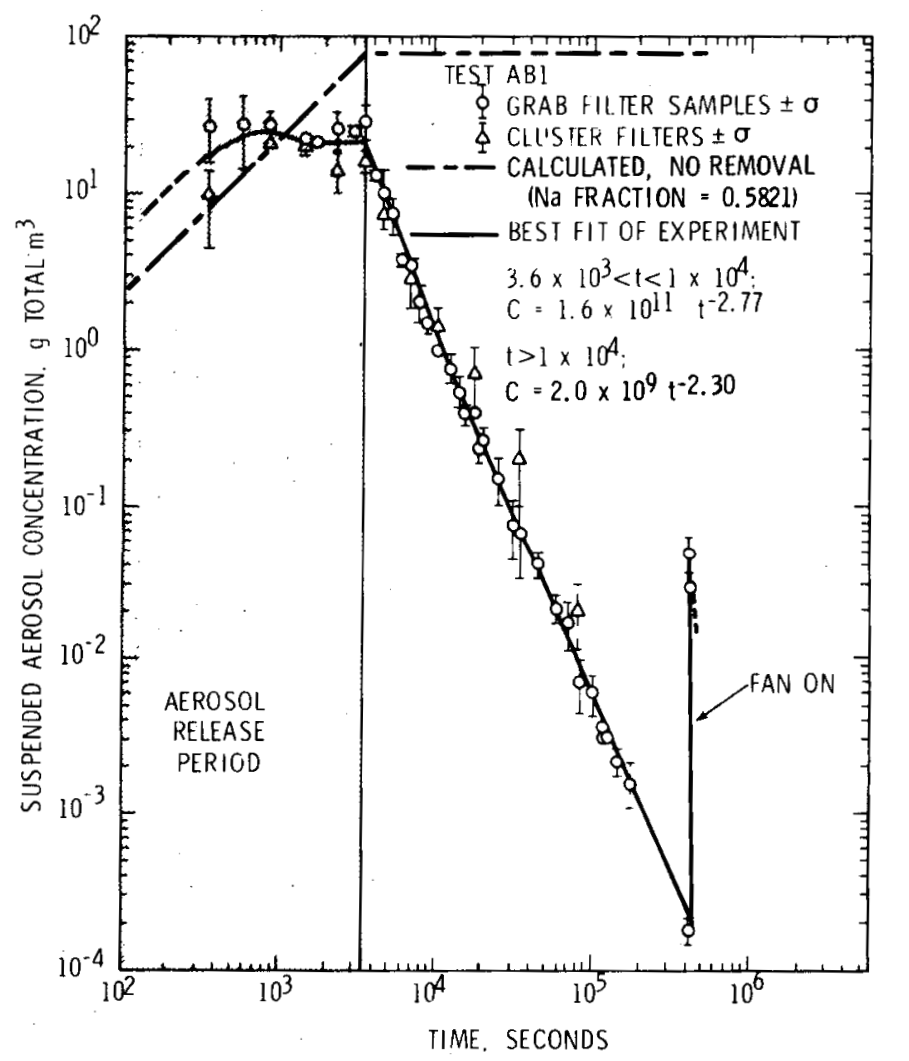

HEDL 7806-14.8

FIGURE 17. Suspended Mass Concentration - Test ABT. 
TABLE 5

\section{SUSPENDED MASS CONCENTRATION - TEST ABI}

\begin{tabular}{l} 
Time (a) \\
\hline $3.6(2)$ \\
$6.0(2)$ \\
$9.0(2)$ \\
$1.5(3)$ \\
$1.8(3)$ \\
$2.4(3)$ \\
$3.1(3)$ \\
$3.6(3)$ \\
$4.2(3)$ \\
$4.8(3)$ \\
$5.4(3)$ \\
$6.3(3)$ \\
$7.2(3)$ \\
$8.1(3)$ \\
$9.0(3)$ \\
$1.1(4)$ \\
$1.3(4)$ \\
$1.5(4)$ \\
$1.6(4)$ \\
$1.75(4)$ \\
$1.93(4)$ \\
$2.09(4)$ \\
$2.60(4)$ \\
$3.20(4)$ \\
$3.80(4)$ \\
$4.60(4)$ \\
$6.09(4)$ \\
$7.38(4)$ \\
$8.70(4)$ \\
$1.03(5)$ \\
$1.08(5)$ \\
$1.19(5)$ \\
$1.27(5)$ \\
$1.35(5)$ \\
$1.49(5)$ \\
$1.82(5)$ \\
$4.17(5)$ \\
$4.27(5)$ \\
$4.42(5)(\mathrm{c})$ \\
\end{tabular}

\begin{tabular}{|c|c|c|c|}
\hline \multicolumn{4}{|c|}{$\begin{array}{c}\text { Suspended Mass Concentration (b) } \\
\left(\mathrm{g} / \mathrm{m}^{3}\right)\end{array}$} \\
\hline \multicolumn{2}{|c|}{ Sodium } & \multicolumn{2}{|c|}{ Total Mass } \\
\hline $\begin{array}{l}5.62(0) \\
1.12(1) \\
1.42(1) \\
1.32(1) \\
1.30(1)\end{array}$ & $\begin{array}{l} \pm 9.0(-1) \\
\pm 5.0(0) \\
\pm 8.3(-1) \\
\pm 2.1(0) \\
\pm 2.2(-1)\end{array}$ & $\begin{array}{l}2.7(1) \\
2.8(1) \\
2.8(1) \\
2.3(1) \\
2.2(1)\end{array}$ & $\begin{array}{l} \pm 1.3(1) \\
\pm 1.4(1) \\
\pm 3.5(0) \\
\pm 4.0(0) \\
\pm 1.5(0)\end{array}$ \\
\hline $\begin{array}{l}1.60(1) \\
1.54(1) \\
1.82(1) \\
8.25(0) \\
6.35(0)\end{array}$ & $\begin{array}{l} \pm 4.5(0) \\
\pm 8.4(-1) \\
\pm 4.4(0) \\
\pm 2.7(-1) \\
\pm 1.8(0)\end{array}$ & $\begin{array}{l}2.6(1) \\
2.5(1) \\
2.9(1) \\
1.3(1) \\
1.0(1)\end{array}$ & $\begin{array}{l} \pm 7.5(0) \\
\pm 2.1(0) \\
\pm 7.3(0) \\
\pm 1.0(0) \\
\pm 2.9(0)\end{array}$ \\
\hline $\begin{array}{l}4.30(0) \\
2.09(0) \\
1.80(0) \\
1.02(0) \\
7.16(-1)\end{array}$ & $\begin{array}{l} \pm 1.1(0) \\
\pm 1.3(-1) \\
\pm 5.1(-1) \\
\pm 2.7(-1) \\
\pm 1.4(-1)\end{array}$ & $\begin{array}{l}7.4(0) \\
3.7(0) \\
3.4(0) \\
2.0(0) \\
1.5(0)\end{array}$ & $\begin{array}{l} \pm 2.0(0) \\
\pm 3.5(-1) \\
\pm 1.0(0) \\
\pm 5.7(-1) \\
\pm 3.3(-1)\end{array}$ \\
\hline $\begin{array}{ll}4.54 & (-1) \\
3.17 & (-1) \\
2.17 & (-1) \\
1.52 & (-1) \\
1.55 & (-1)\end{array}$ & $\begin{array}{l} \pm 5.9(-2) \\
\pm 3.6(-2) \\
\pm 4.8(-2) \\
\pm 1.2(-2) \\
\pm 5.0(-3)\end{array}$ & $\begin{array}{ll}1.0 & (0) \\
7.5(-1) \\
5.3(-1) \\
3.8(-1) \\
4.0(-1)\end{array}$ & $\begin{array}{l} \pm 1.7(-1) \\
\pm 1.5(-1) \\
\pm 1.4(-1) \\
\pm 6.4(-2) \\
\pm 7.3(-2)\end{array}$ \\
\hline $\begin{array}{ll}8.95 & (-2) \\
9.89 & (-2) \\
5.60 & (-2) \\
2.78 & (-2) \\
2.48 & (-2)\end{array}$ & $\begin{array}{l} \pm 7.4(-3) \\
\pm 4.9(-4) \\
\pm 7.7(-2) \\
\pm 7.7(-2) \\
\pm 4.7(-3)\end{array}$ & $\begin{array}{ll}2.3 & (-1) \\
2.6 & (-1) \\
1.5 & (-1) \\
7.5 & (-2) \\
6.7 & (-2)\end{array}$ & $\begin{array}{l} \pm 4.5(-2) \\
\pm 4.8(-2) \\
\pm 5.3(-2) \\
\pm 3.3(-2) \\
\pm 3.5(-2)\end{array}$ \\
\hline $\begin{array}{ll}1.50 & (-2) \\
7.46 & (-3) \\
5.97 & (-3) \\
2.52 & (-3) \\
2.19 & (-3)\end{array}$ & $\begin{array}{l} \pm 9.8(-4) \\
\pm 7.0(-4) \\
\pm 7.8(-3) \\
\pm 8.5(-4) \\
\pm 3.6(-4)\end{array}$ & $\begin{array}{ll}4.0 & (-2) \\
2.1 & (-2) \\
1.7 & (-2) \\
7.0 & (-3) \\
6.1 & (-3)\end{array}$ & $\begin{array}{l} \pm 8.0(-3) \\
\pm 4.1(-3) \\
\pm 6.7(-3) \\
\pm 2.7(-3) \\
\pm 7.6(-3)\end{array}$ \\
\hline $\begin{array}{ll}1.55 & (-3) \\
1.33 & (-3) \\
1.14 & (-3) \\
.11 & (-3) \\
.74 & (-4)\end{array}$ & $\begin{array}{l} \pm 1.4(-5) \\
\pm 3.5(-5) \\
\pm 2.1(-4) \\
\pm 2.0(-4) \\
\pm 5.8(-5)\end{array}$ & $\begin{array}{ll}4.3 & (-3) \\
3.7 & (-3) \\
3.2 & (-3) \\
3.7 & (-3) \\
2.2 & (-3)\end{array}$ & $\begin{array}{l} \pm 8.4(-4) \\
\pm 6.5(-4) \\
\pm 8.5(-4) \\
\pm 8.2(-4) \\
\pm 4.6(-4)\end{array}$ \\
\hline 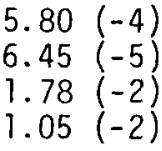 & $\begin{array}{l} \pm 1.5(-4) \\
\pm 2.1(-6) \\
\pm 3.5(-3) \\
\pm 3.0(-3)\end{array}$ & $\begin{array}{ll}1.6 & (-3) \\
1.8 & (-4) \\
4.9 & (-2) \\
2.9 & (-2)\end{array}$ & $\begin{array}{l} \pm 5.2(-4) \\
\pm 3.3(-5) \\
\pm 1.4(-2) \\
\pm 7.0(-2)\end{array}$ \\
\hline
\end{tabular}

(a) Numbers in parentheses are exponents of base 10 ; e.g., read $1.05(-2)$ as $1.05 \times 10^{-2}$.

(b) Mean of four sampling locations.

(c) Ventilation fan started at 4.25 (5) seconds. 
TABLE 6

SUSPENDED MASS CONCENTRATION - TEST AB2

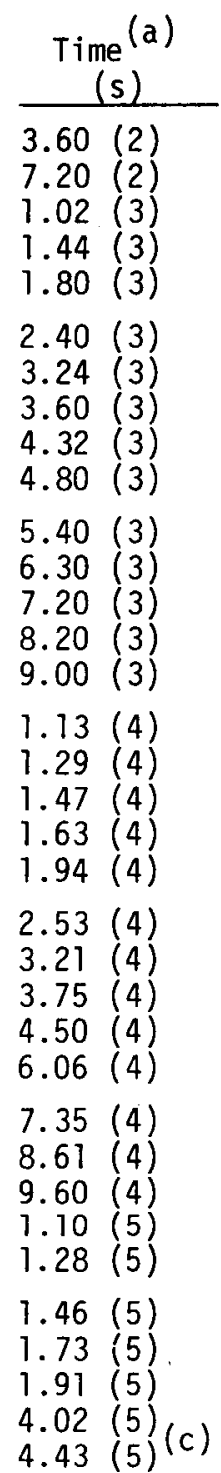

Suspended Mass Concentration (b) $\left(\mathrm{g} / \mathrm{m}^{3}\right)$

\begin{tabular}{|c|c|c|c|}
\hline \multicolumn{2}{|c|}{ Sodium } & \multicolumn{2}{|c|}{ Total Mass } \\
\hline $\begin{array}{l}7.32(0) \\
1.09(1) \\
7.30(0) \\
9.83(0) \\
8.97(0)\end{array}$ & $\begin{array}{l} \pm 4.3(0) \\
\pm 1.5(0) \\
\pm 1.5(0) \\
\pm 1.3(0) \\
\pm 1.5(0)\end{array}$ & $\begin{array}{l}1.74(1) \\
2.22(1) \\
1.49(1) \\
2.18(1) \\
2.22(1)\end{array}$ & $\begin{array}{l} \pm 1.0(1) \\
\pm 3.6(0) \\
\pm 3.3(0) \\
\pm 3.5(0) \\
\pm 4.2(0)\end{array}$ \\
\hline $\begin{array}{l}1.09(1) \\
1.11(1) \\
1.26(1) \\
9.11(0) \\
6.22(0)\end{array}$ & $\begin{array}{l} \pm 2.9(0) \\
\pm 1.8(0) \\
\pm 2.5(0) \\
\pm 2.5(0) \\
\pm 1.1(0)\end{array}$ & $\begin{array}{l}2.73(1) \\
2.85(1) \\
3.60(1) \\
3.14(1) \\
2.30(1)\end{array}$ & $\begin{array}{l} \pm 7.8(0) \\
\pm 5.5(0) \\
\pm 8.2(0) \\
\pm 3.4(0) \\
\pm 4.8(0)\end{array}$ \\
\hline $\begin{array}{l}4.29(0) \\
3.26(0) \\
2.24(0) \\
9.92(0) \\
1.61(0)\end{array}$ & $\begin{array}{l} \pm 9.1(-1) \\
\pm 6.1(-1) \\
\pm 2.5(-1) \\
\pm 5.9(-1) \\
\pm 6.0(-1)\end{array}$ & $\begin{array}{l}1.59(1) \\
1.21(1) \\
8.00(0) \\
6.86(0) \\
5.75(0)\end{array}$ & $\begin{array}{l} \pm 3.8(0) \\
\pm 2.6(0) \\
\pm 1.4(0) \\
\pm 2.3(0) \\
\pm 2.3(0)\end{array}$ \\
\hline $\begin{array}{l}6.58(-1) \\
3.03(-1) \\
2.86(-1) \\
2.53(-1) \\
1.88(-1)\end{array}$ & $\begin{array}{l} \pm 2.3(-1) \\
\pm 3.0(-2) \\
\pm 7.2(-2) \\
\pm 9.0(-3) \\
\pm 2.2(-2)\end{array}$ & $\begin{array}{l}2.35(0) \\
1.08(0) \\
1.02(0) \\
9.05(-1) \\
6.48(-1)\end{array}$ & $\begin{array}{l} \pm 8.9(-1) \\
\pm 1.9(-1) \\
\pm 3.0(-1) \\
\pm 1.3(-1) \\
\pm 1.2(-1)\end{array}$ \\
\hline $\begin{array}{l}1.20(-1) \\
7.07(-2) \\
4.90(-2) \\
3.28(-2) \\
2.05(-2)\end{array}$ & $\begin{array}{l} \pm 1.1(-2) \\
\pm 2.5(-3) \\
\pm 5.6(-3) \\
\pm 3.6(-3) \\
\pm 2.1(-3)\end{array}$ & $\begin{array}{l}4.00(-1) \\
2.35(-1) \\
1.63(-1) \\
1.09(-1) \\
6.61(-2)\end{array}$ & $\begin{array}{l} \pm 6.5(-2) \\
\pm 3.2(-2) \\
\pm 2.9(-2) \\
\pm 1.9(-2) \\
\pm 1.1(-2)\end{array}$ \\
\hline $\begin{array}{l}1.57(-2) \\
1.08(-2) \\
7.63(-3) \\
6.05(-3) \\
4.95(-3)\end{array}$ & $\begin{array}{l} \pm 1.2(-3) \\
\pm 9.1(-4) \\
\pm 2.2(-3) \\
\pm 5.1(-4) \\
\pm 1.1(-3)\end{array}$ & $\begin{array}{l}5.06(-2) \\
3.48(-2) \\
2.38(-2) \\
1.89(-2) \\
1.55(-2)\end{array}$ & $\begin{array}{l} \pm 9.0(-3) \\
\pm 6.3(-3) \\
\pm 7.8(-3) \\
\pm 3.3(-3) \\
\pm 4.2(-3)\end{array}$ \\
\hline $\begin{array}{ll}3.17 & (-3) \\
2.15 & (-3) \\
1.50 & (-3) \\
1.72 & (-4) \\
<3.0 & (-5)\end{array}$ & $\begin{array}{l} \pm 2.9(-4) \\
\pm 3.9(-4) \\
\pm 1.4(-4) \\
\pm 1.1(-5)\end{array}$ & $\begin{array}{l}1.02(-2) \\
6.72(-3) \\
4.69(-3) \\
5.06(-4) \\
<8.8(-5)\end{array}$ & $\begin{array}{l} \pm 1.8(-3) \\
\pm 1.6(-3) \\
\pm 8.6(-4) \\
\pm 8.0(-5)\end{array}$ \\
\hline
\end{tabular}

\footnotetext{
(a) Numbers in parentheses are exponents of base 10 .

(b) Mean of four sampling locations.

(c) Ventilation fan started at 4.42 (5) seconds.
} 


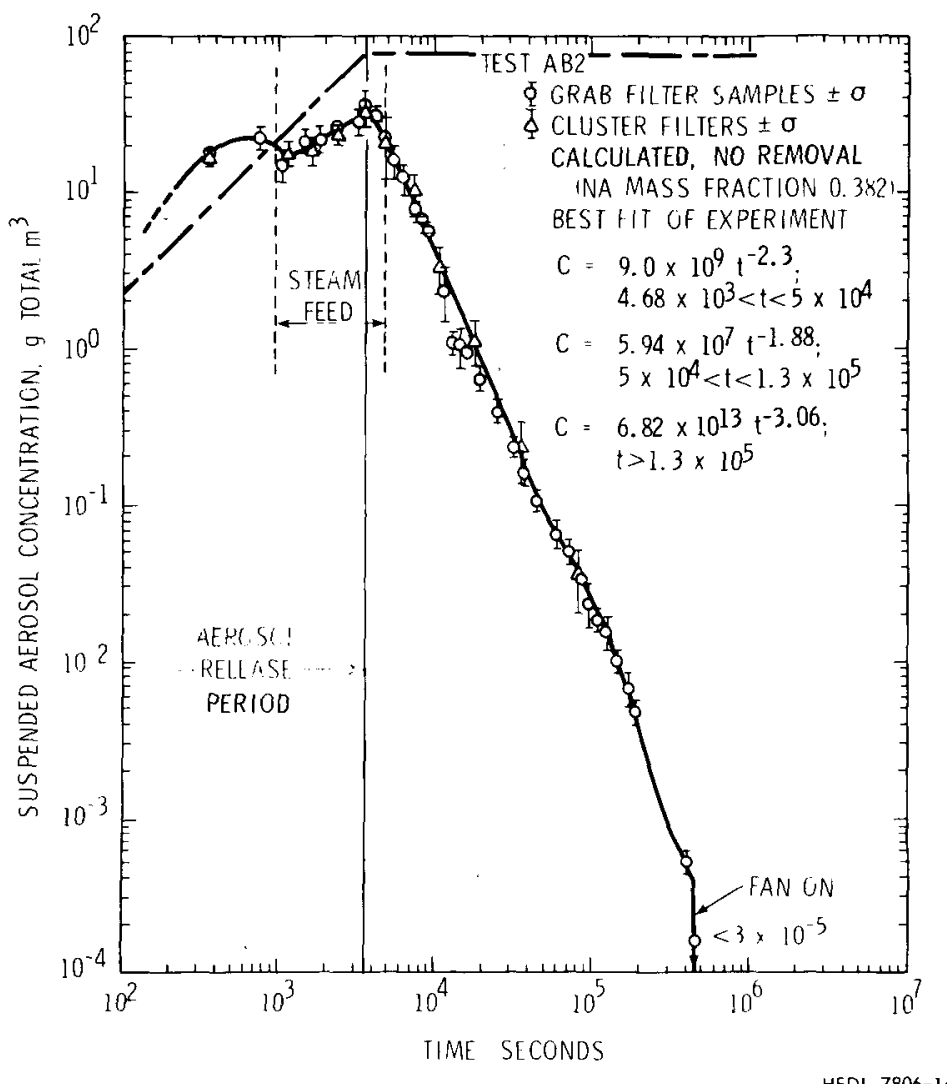

FIGURE 18. Suspended Mass Concentration - Test AB2.

As soon as the burn pan lid was closed, stopping the aerosol release, the concentrations decreased rapidly with ever-increasing half times. The concentration of dry aerosol in Test $A B 1$ decreased more rapidly than the wet $A B 2$ aerosol after the source was terminated, but the wet aerosol was removed more rapidly during the source period. The overall result was that the attenuation factor for suspended aerosol mass was higher in $A B 2$ and in $A B 1$.

Detailed data for filter samples are presented in Appendix A.

\section{F. AEROSOL PARTICLE SIZE DISTRIBUTION}

The aerodynamic size distribution of the suspended aerosol mass was measured by inserting two types of cascade impactors directly into the containment 
atmosphere in a horizontal position. Although there was no inlet tube, some deposition did occur in the nose sections upstream of the first stages. This material was neglected in analyzing the data. A typical example of the data plotted on log-normal coordinates as the stage cutoff diameter versus the mass fraction penetrating that stage is shown in Figure 19. If the particle distribution is log-normal, a straight line should be obtained and the two major parameters of particle size distribution can be obtained: the aerodynamic mass median diameter (AMMD) and the geometric standard deviation $\left(\sigma_{g}\right)$. Most of the 44 cascade impactor samples taken in these tests gave good straightline approximations on log-normal coordinates, through a few showed significant deviations. The method of treating the cascade impactor data and detailed results are provided in Appendix B.

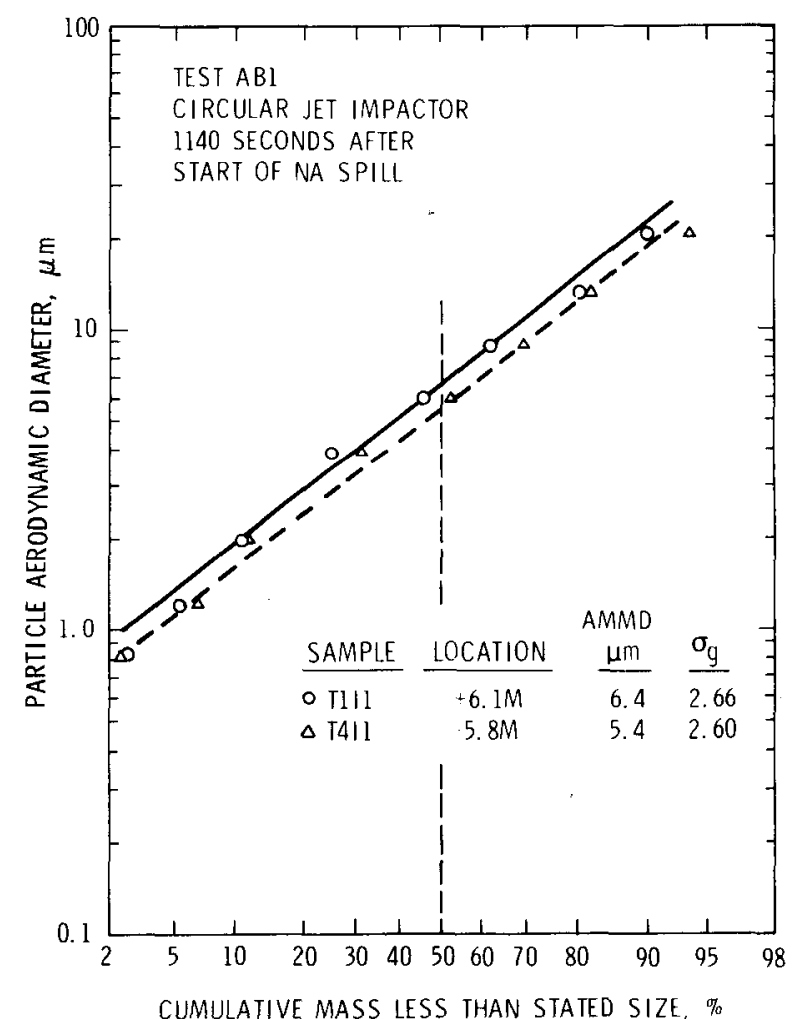

HEDL $7806-14.2$

FIGURE 19. Typical Cascade Impactor Data Plot on Log-Normal Coordinates. 
Samples were taken simultaneously from high and low containment locations. No consistent difference was found for the two locations, which supports the conclusion made earlier that the gas space was well mixed. The results for the upper and lower samples were averaged and plotted as functions of time (see Figures 20 and 21 ) for the AMMD and $\sigma_{g}$, respectively.

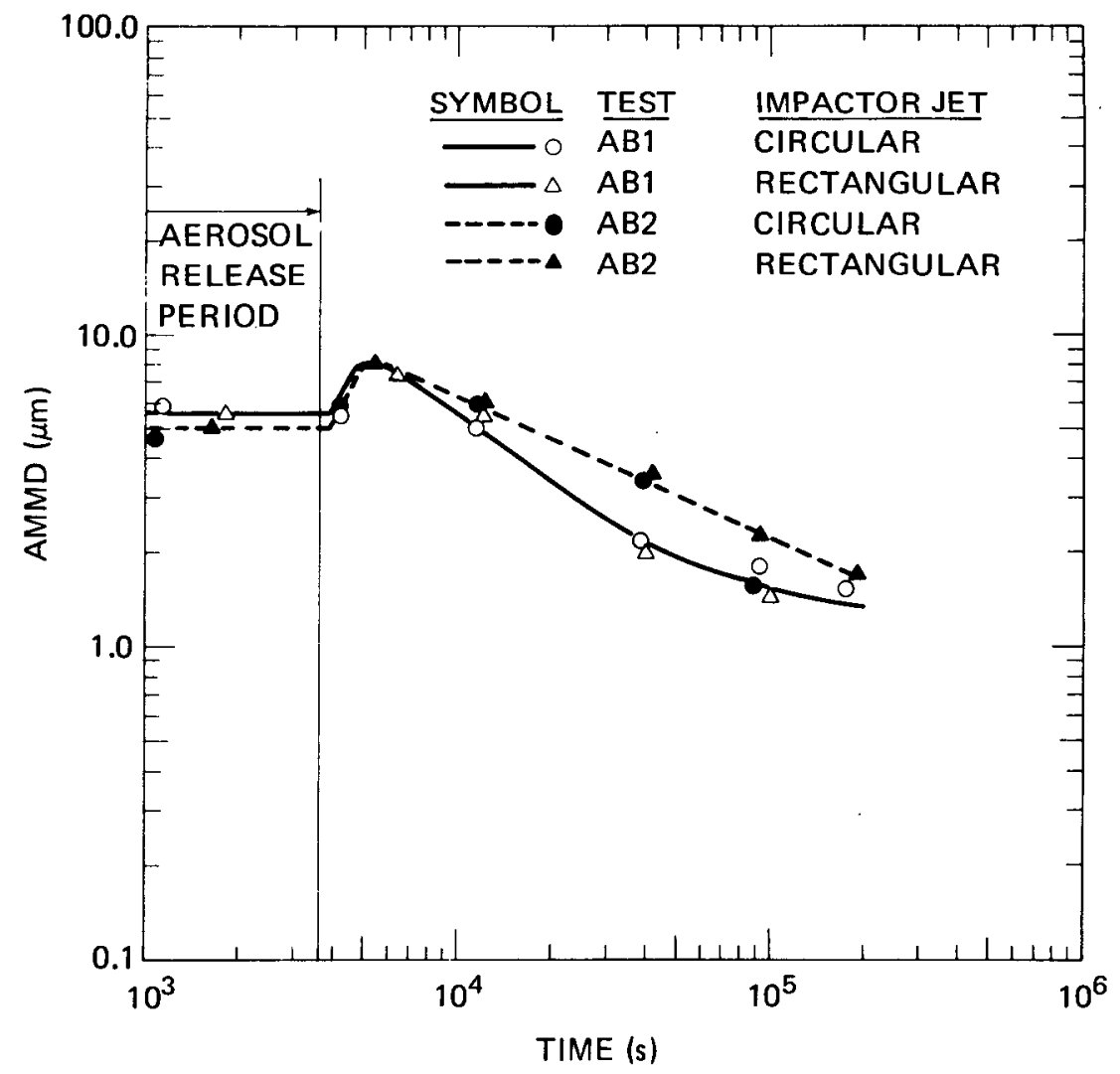

HEDL 7904-28.3

FIGURE 20. Aerodynamic Mass Median Diameter of Suspended Particles. 


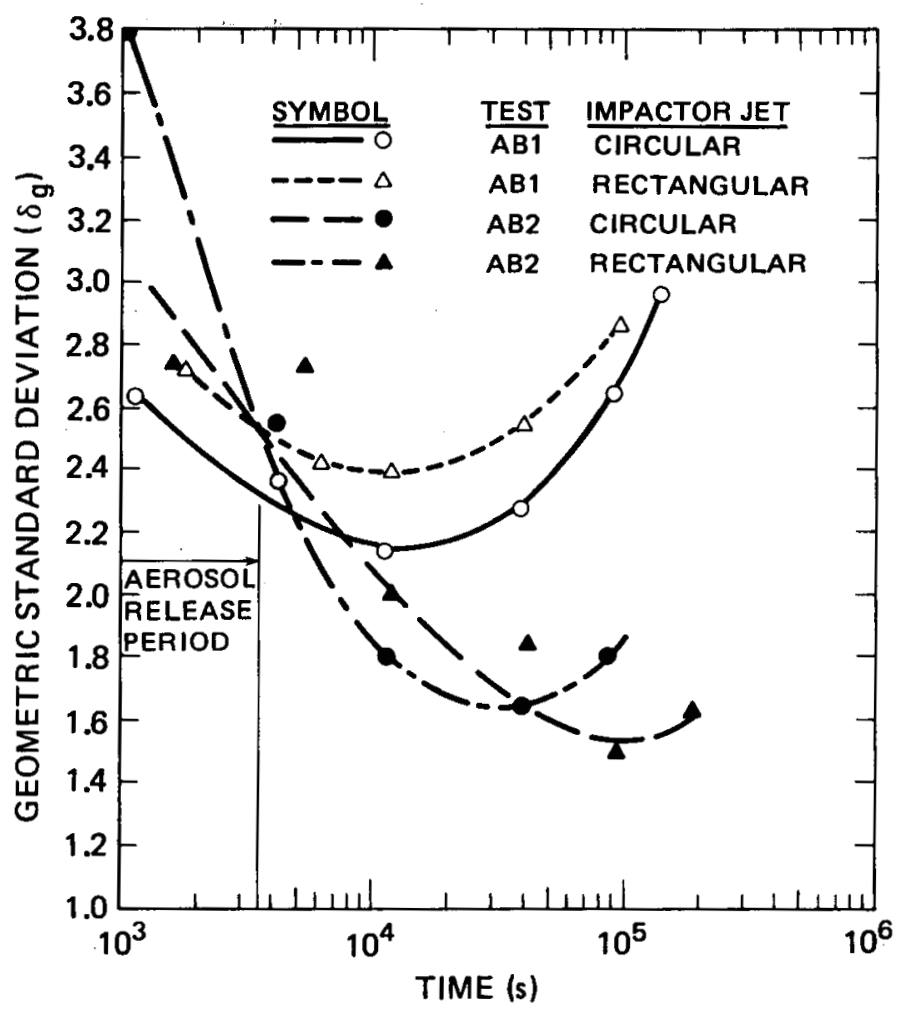

HEDL 7904-28.4

FIGURE 21. Geometric Standard Deviation of Suspended Particle Size.

A comparison of the cascade impactor results with the settling diameter $d_{s}$, calculated from the rate of depletion of airborne concentration, is given in Figures 22 and 23 . If the distribution is log-normal, the aerodynamic settling diameter can be calculated from the cascade impactor AMMD by equation (1).

$$
d_{s}=A M M D \exp \left(3 n^{2} \sigma_{g}\right)
$$

The aerodynamic settling diameters were calculated from the airborne concentration curves (Figures 17 and 18) by differentiating the curves and equating with the Stokes settling removal term. This neglects wall plateout, which is reasonable in view of the fact that $93 \%$ of the mass settled and only $7 \%$ plated. Thus,

$$
\frac{d C}{d t}=\frac{u_{t} A_{s} C}{V}
$$




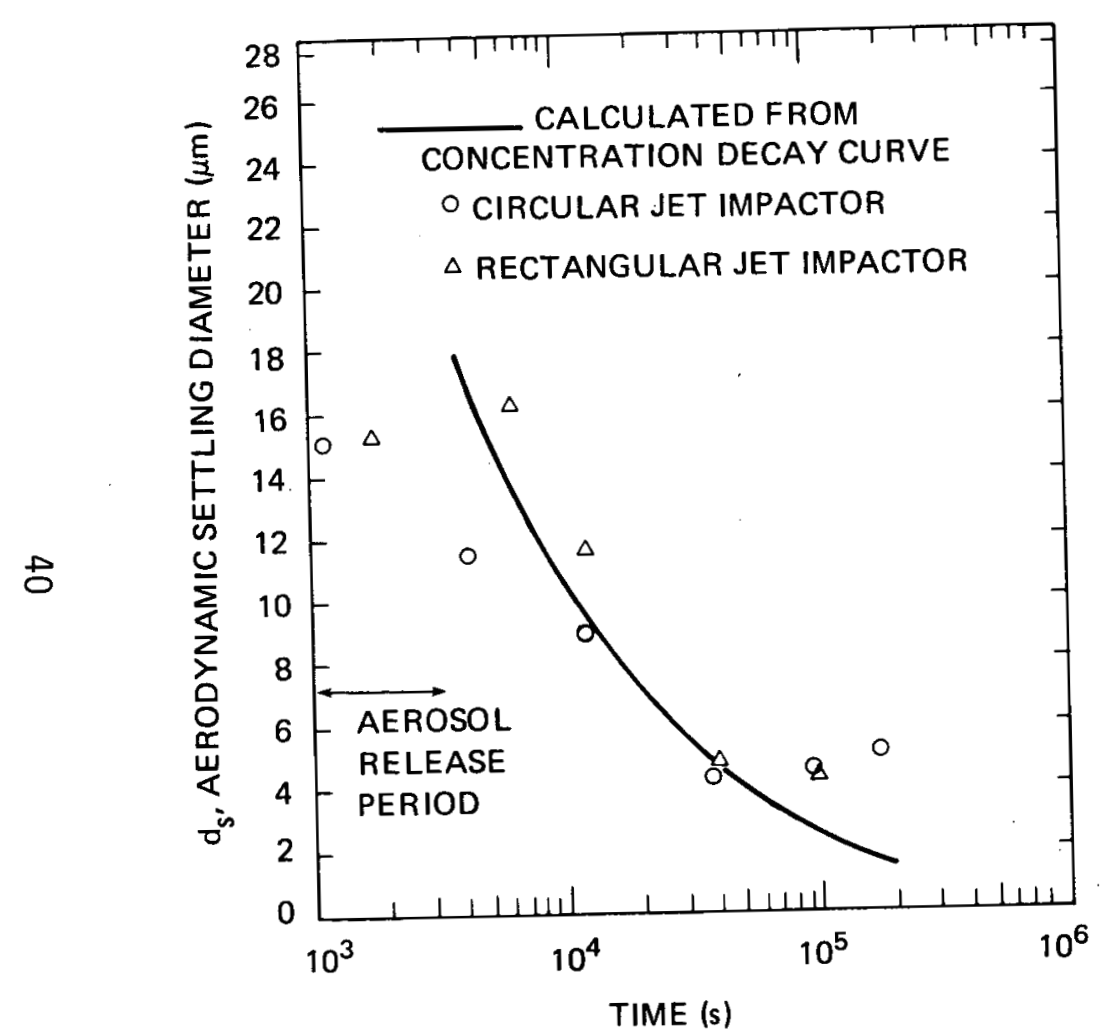

HEDL 7904-28.5

FIGURE 22. Comparison of Aerodynamic Settling Diameters From Cascade Impactor and Airborne Depletion Data - Test ABI.

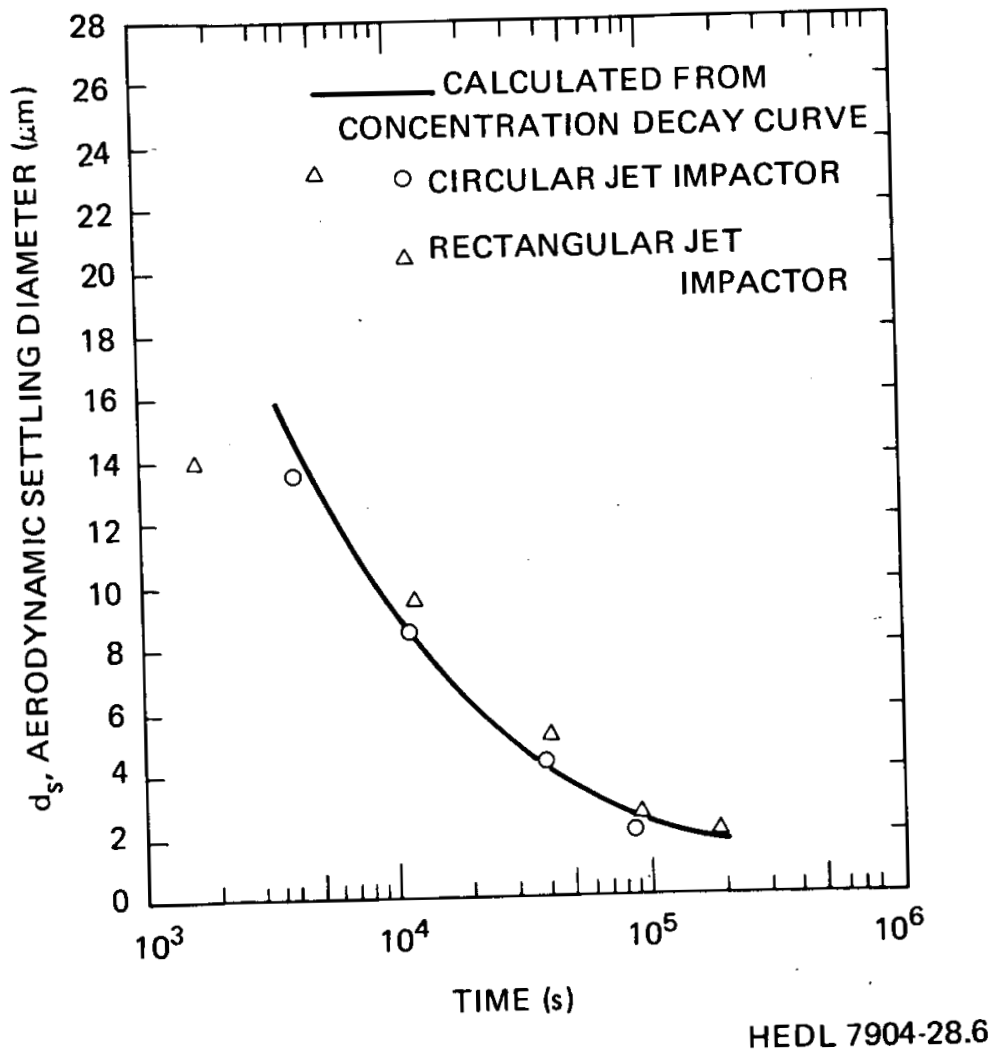

FIGURE 23. Comparison of Aerodynamic Settling Diameters From Cascade Impactor and Airborne Depletion Data - Test AB2. 
Where:

$C=$ Time dependent suspended mass concentration,

$u_{t}=$ Terminal settling velocity,

$A_{s}=$ Horizontal surface area, and

$\mathrm{V}=$ Gas volume.

The settling velocity $u_{t}$ was calculated by equation (2) and the settling diameter calculated from Stoke's law:

$$
d_{s}=\left[\frac{18 \mu_{f} u_{t}}{g \rho_{p}}\right]^{0.5}
$$

Where:

$$
\begin{aligned}
\mu_{f} & =\text { Fluid viscosity } \\
g & =\text { Acceleration due to gravity, and } \\
\rho_{p} & =\text { Effective particle density. }
\end{aligned}
$$

In using equation (3), the particles were assumed to be sperical with unit density in order to compare with the similar assumption used for the cascade impactor data. Figures 22 and 23 show that fairly good agreement was obtained.

Particle deposition rates were also obtained by means of deposition coupons inserted through the air lock sampling stations. Particles deposited onto the upper surfaces of the circular steel discs $(5.11-\mathrm{cm}$ diam) were dissolved in water and analyzed for sodium. A deposition velocity can be computed by dividing the deposited mass by exposure time and gas phase concentration:

$$
u_{t}=\frac{\text { Mass of Na per area }}{\text { (exposure time)(mass concentration of } \mathrm{Na})}
$$

A settling diameter can be computed from the deposition velocity $u_{t}$ and Stokes law as indicated in equation (3).

Deposition coupon samples were withdrawn simultaneously from as many as four sampling stations. Deposition velocities for the several locations were averaged to determine a settling diameter. Results obtained for Test $A B 1$ are 
shown in Figure 24, and results for Test $A B 2$ are presented in Figure 25. Detailed numerical data are given in Appendix $C$.

The settling mean particle sizes obtained by the deposition coupons are in good agreement with sizes obtained from the cascade impactors. The settling mean from coupon data also agrees well with the size computed from the concentration decay curve and with the one measurement ( $A B 2$ ) made with the gravity settling sampler.

Agreement in the particle sizes obtained by the several methods supports the validity of the size measurements and indicates that the particles were not broken into smaller sizes within the impactors. Prior to the tests there were misgivings about cascade impactors because of possible fracturing of the agglomerates formed by sodium oxide aerosol.

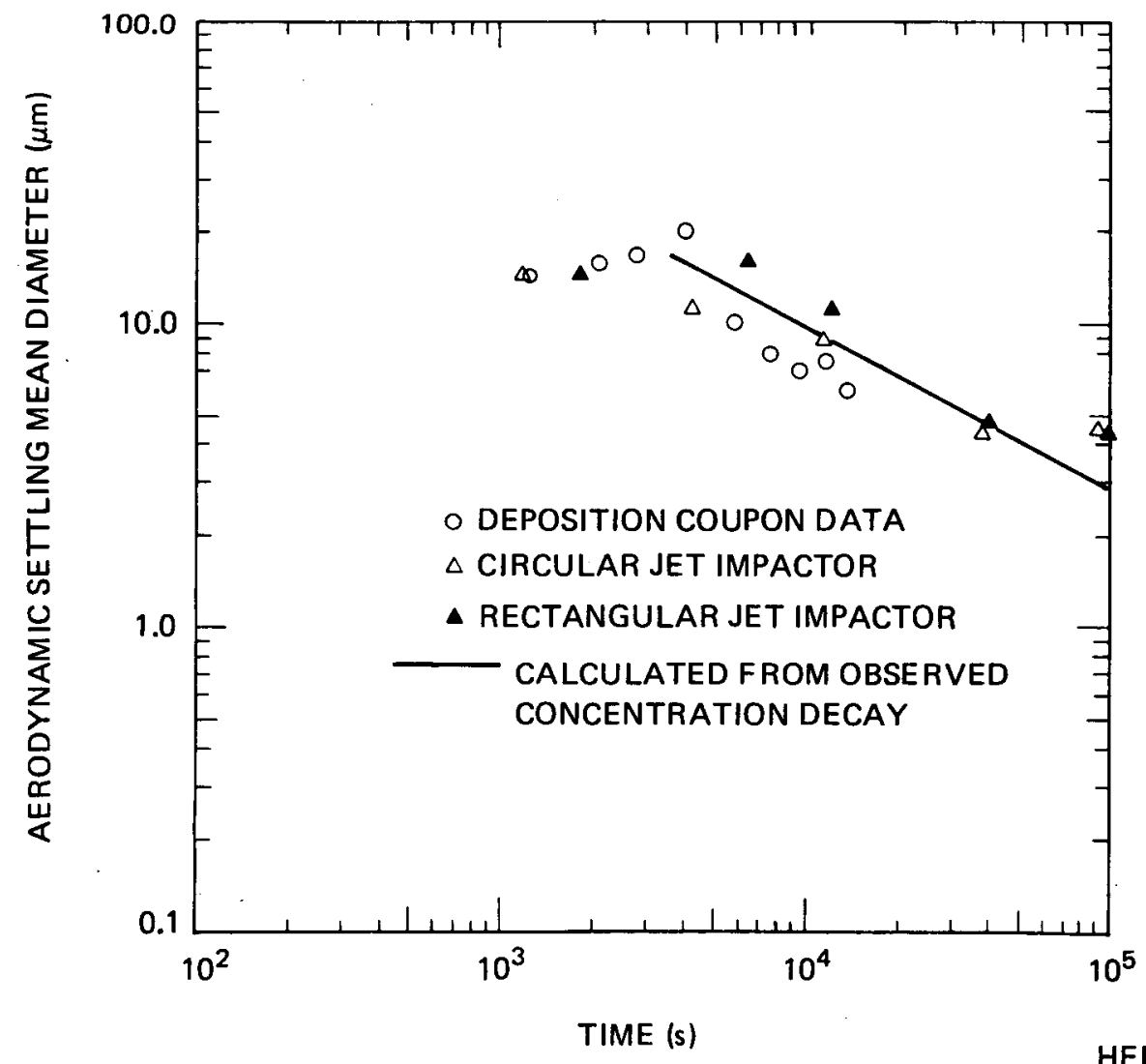

HEDL 7904-28.7

FIGURE 24. Comparison of Particle Size Inferred From Deposition Coupons With Other Size Measurements in Test AB1. 


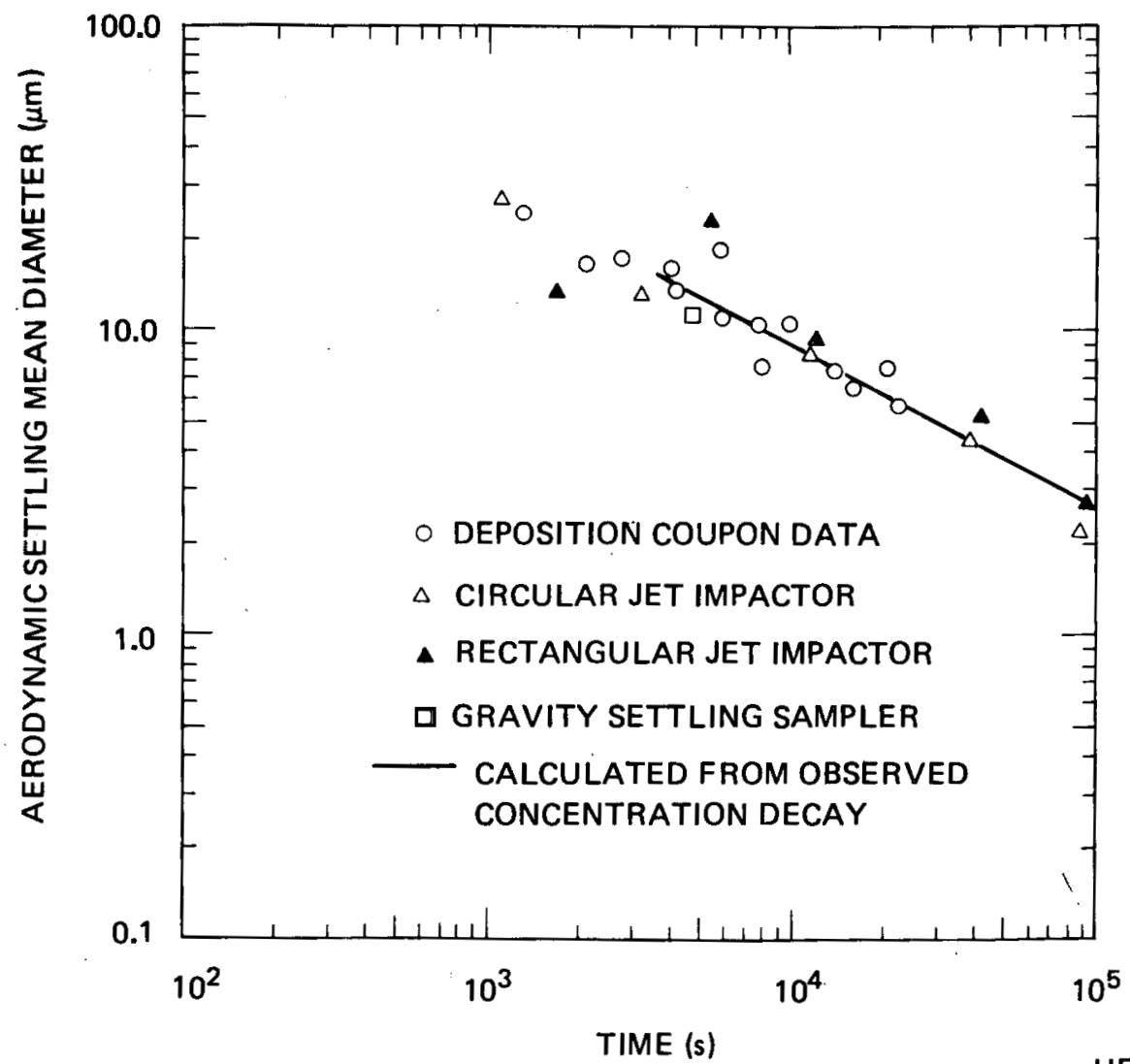

HEDL 7904-28.8

FIGURE 25. Comparison of Particle Size Inferred From Deposition Coupons With Other Size Measurements in Test AB2.

\section{G. AEROSOL PHYSICAL PROPERTIES}

\section{Particle Shape and Density}

The bulk density of the composite deposited aerosol materials recovered from the floor after Test $A B 1$ was determined by weight and volume measurements to be $0.33 \pm 0.03 \mathrm{~g} / \mathrm{cm}^{3}$. This agrees well with the value of 0.32 reported by First and Yusa. (17) After tapping 100 times in a graduated cylinder, the bulk density increased to $0.60 \pm 0.10 \mathrm{~g} / \mathrm{cm}^{3}$. The material density of the $A B 1$ material was not determined, but a similar sample with the same nominal composition (Test AB3) was found to have a material density of $2.3 \pm 0.3 \mathrm{~g} / \mathrm{cm}^{3}$ by immersion in acetone. The handbook value, based on the analysis of sample S5 in Table 4 was $2.30 \mathrm{~g} / \mathrm{cm}^{3}$. 
No density measurements were made of the aerosol material in Test AB2, but it was believed to have been liquid during most of the test. At the end of the test 13.4 \& of $65 \mathrm{wt} \% \mathrm{NaOH}$ solution was drained from the vesse1; however, portions of the vessel surface had a deposit of solid material. The agglomerated aerosol particles probably contained some void space due to oxygen gas emitted by the reaction of $\mathrm{Na}_{2} \mathrm{O}_{2}$ and water and to the insolubility of the small amounts of sodium carbonate that formed. No direct measurements were made of the particle density.

Electron microscope grids were exposed briefly to the containment atmosphere at various times. They were protected from exposure to ambient air by withdrawing the holder into an 0-ring sealed protector before removing it from the containment vessel. Figure 26 shows some typical photomicrographs of samples taken at four times during Test $A B 1$. The indices shown in the figure are set at $10 \mu \mathrm{m}$. The projected diameters of the primary particles ranged from 0.1 to $0.5 \mathrm{\mu m}$. The settled agglomerates were irregular shapes of 21 - to 5-um diameter at $8 \mathrm{~min}$. They had grown to 1 - to $30-\mu \mathrm{m}$ diameter spheres by the end of the sodium fire. The larger particles appeared to contain voids. Shadowing techniques were not used, but stereoscopic examination showed the particles to be approximately sphericál.

\section{Particle Electric Charge}

Particle charge distributions were measured by the use of a parallel plate charge analyzer of the type described by Megaw and Wells. (15) For both tests the sample flow was started 30 minutes after the sodium spill and lasted for 10 minutes. Filtered sheath air flow at $11 \mathrm{~cm}^{3} / \mathrm{s}$ was recirculated by a small diaphragm pump, and a net sample flow of $2 \mathrm{~cm}^{3} / \mathrm{s}$ was bled through the analyzer and its backup filter. The apparatus was operated at 10,000 $\mathrm{V}$ for $\mathrm{AB} 1$ and $4000 \mathrm{~V}$ for Test $\mathrm{AB} 2$. Any particle with a mobility greater than $7.7 \times 10^{-6}$ and $1.9 \times 10^{-5} \mathrm{~cm}^{2} / \mathrm{V}$, respectively, would be collected on the plates. These limiting mobilites are equivalent to a $1-\mu \mathrm{m}$ particle carrying one and three electronic charges, respectively. 


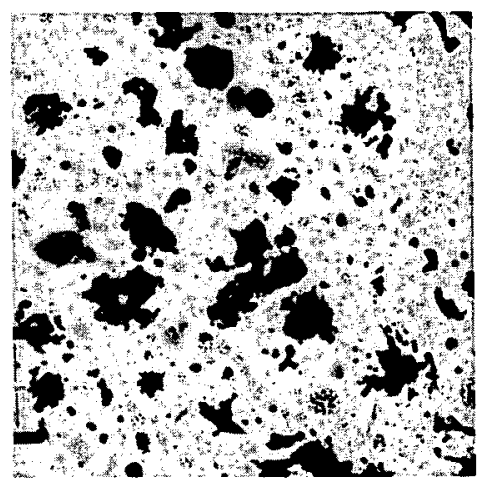

A. Time: 8 min. (7710649-1)

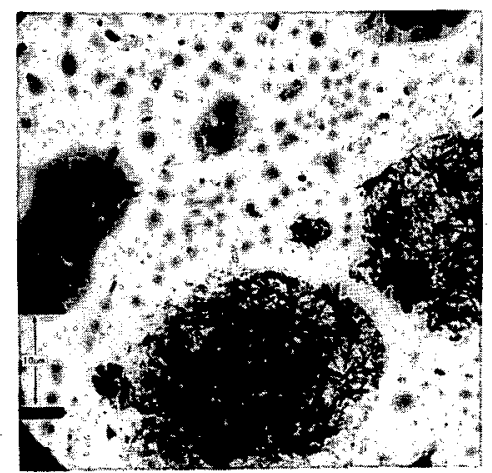

C. Time: 190 min. (7710649-2)

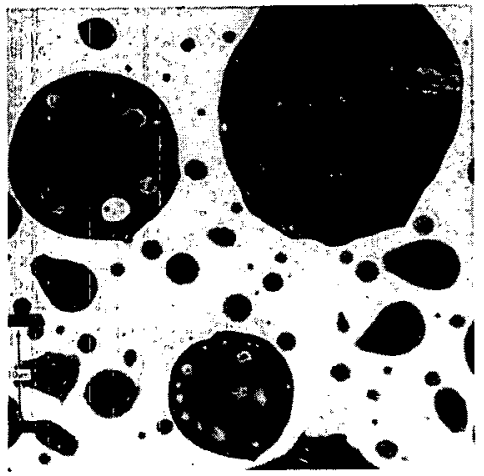

B. Time: 56 min. (7710649-4)

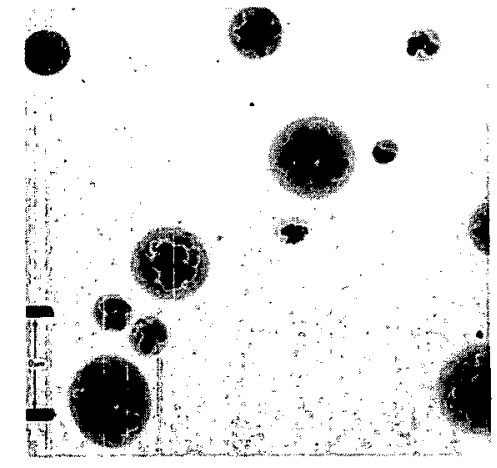

FIGURE 26. Electron Photomicrographs of Gravity-Settled Particles at Various Times in Test $A B 1$. 
Table 7 gives the particle charge distribution, and the data indicate that the dry particles in Test $A B I$ had a higher charge than the wet aerosol but that the net charge was close to zero in both tests.

TABLE 7

PARTICLE CHARGE DISTRIBUTION

$\begin{array}{lccc} & \mathrm{AB} 1 & \mathrm{AB} 2 \\ \text { Mass Fraction on Positive Plate } & 0.46 & 0.07 \\ \text { Mass Fraction on Negative Plate } & 0.45 & 0.07 \\ \text { Mass Fraction on Backup Filter } & 0.09 & 0.86 \\ \text { Limiting Mobility }\left(\mathrm{cm}^{2} / \mathrm{v}-5\right)(\mathrm{a}) & 7.7 \times 10^{-6} & 1.9 \times 10^{-5}\end{array}$

(a) The limiting mobility is defined as that for which the particle would just be captured at the end of the plates. Particles with lower mobilities would be captured on the outlet filter.

\section{BuTk Density of Deposited Powder}

The bulk density of the aerosol material recovered from the cell floor after Test $A B 1$ was $0.33 \pm 0.03 \mathrm{~g} / \mathrm{cm}^{3}$. After vibrating by tapping 100 times in a graduated cylinder, the density of the powder increased to $0.60 \pm 0.10 \mathrm{~g} / \mathrm{cm}^{3}$. These densities are $14 \%$ and $25 \%$ of the estimated material density of 2.42 $\mathrm{g} / \mathrm{cm}^{3}$ for this test.

In Test AB2, the added steam converted aerosols to a viscous liquid; thus, no dry powder was present at the end of the test and no density measurements were made. 


\section{H. SODIUM MASS BALANCE}

After each test, burn pan residues and aerosol deposited on vessel surfaces were analyzed to determine the chemical species present and their respective masses.

\section{Burn Pan Residue Analysis}

After the test was completed, the burn pan was 1 ifted from the vessel, the lid was opened, and samples were removed from several locations. Both metallic sodium and oxide phases were found in layer form. The oxide layer was above the metallic layer in Test $A B 1$ while the reverse was true in Test $A B 2$. Samples were taken from both layers and the volumes and densities of each were estimated. In addition, the total weight of the burn pan was measured on a scale.

The metallic layer was analyzed for metallic and total sodium. Metallic sodium was separated out using an extraction with mercury. Combined sodium was obtained by the difference between total sodium and metallic sodium and was assumed to be in the form of $\mathrm{Na}_{2} \mathrm{O}$ since other oxide forms would be unstable in hot sodium metal.

In the oxide layer, analyses were performed to determine the fractional abundances of $\mathrm{Na}, \mathrm{Na}_{2} \mathrm{O}, \mathrm{Na}_{2} \mathrm{O}_{2}, \mathrm{NaOH}$, and $\mathrm{Na}_{2} \mathrm{CO}_{3}$.

- $\quad \mathrm{Na}$ was separated out by vacuum distillation at $350^{\circ} \mathrm{C}$.

- $\mathrm{Na}_{2} \mathrm{O}_{2}$ was measured by reaction with iodide ion to give free jodine, which was in turn titrated with thiosulfate.

- $\mathrm{Na}_{2} \mathrm{CO}_{3}$ was determined by treating with acid and measuring $\mathrm{CO}_{2}$ by gas chromatography.

- $\quad \mathrm{Na}_{2} \mathrm{O}$ and $\mathrm{NaOH}$ were determined by difference and a material balance. 
TABLE 8

CHEMICAL ANALYSIS OF BURN PAN RESIDUE - TEST ABT

\begin{tabular}{|c|c|c|c|c|c|c|}
\hline \multirow[b]{2}{*}{ Sample Number } & \multicolumn{5}{|c|}{ Weight Percent } & \multirow{2}{*}{$\begin{array}{l}\text { Total } \\
\text { Mass } \\
\text { (kg) }\end{array}$} \\
\hline & $\begin{array}{c}\text { Total } \\
\mathrm{Na} \\
\end{array}$ & $\begin{array}{l}\text { Metallic } \\
\mathrm{Na} \\
\end{array}$ & $\underline{\mathrm{Na}}_{2} \mathrm{O}^{(\mathrm{a})}$ & $\underline{\mathrm{Na}_{2} \mathrm{O}_{2}}$ & $\underline{\mathrm{Na}_{2} \mathrm{CO}_{3}}$ & \\
\hline \multicolumn{7}{|l|}{ OXIDE LAYER } \\
\hline RI & 65.5 & $<0.5$ & 90.0 & 9.5 & 0.5 & \\
\hline $\mathrm{R} 2$ & 68.8 & $<0.5$ & 93.8 & 5.2 & 1.0 & \\
\hline R3 & 67.1 & $<0.5$ & 91.5 & 8.3 & 0.2 & \\
\hline R4 & 86.9 & $<0.5$ & 92.0 & 7.7 & 0.3 & \\
\hline R5 & 73.8 & $<0.5$ & 96.8 & 2.9 & 0.3 & \\
\hline R10 & 72.0 & $<0.5$ & 90.0 & 3.5 & 6.5 & \\
\hline R11 & 67.4 & $\leq 0.5$ & 90.4 & 8.5 & 1.1 & \\
\hline AVERAGE & 71.6 & $<0.5$ & 92.0 & 6.5 & 1.4 & $140^{(b)}$ \\
\hline \multicolumn{7}{|l|}{ METALLIC LAYER } \\
\hline $\mathrm{R} 6$ & - & 99.4 & 0.4 & - & - & \\
\hline R7 & - & 99.3 & 0.7 & - & - & \\
\hline R8 & - & 92.3 & 7.7 & - & - & \\
\hline R9 & $z$ & 80.8 & 19.2 & - & - & \\
\hline AVERAGE & - & 93.0 & 7.0 & - & - & $275^{(b)}$ \\
\hline \multicolumn{7}{|l|}{ TOTAL BURN PAN } \\
\hline AVERAGE & & 61.5 & 35.8 & 2.2 & 0.5 & $415^{(c)}$ \\
\hline $\begin{array}{l}\text { (a) Calculated by } \\
\text { present. } \\
\text { (b) Estimated fror } \\
\text { weight made b } \\
\text { (c) Measured by s }\end{array}$ & $\begin{array}{l}\text { differe } \\
\text { m volume } \\
\text { y scale. } \\
\text { cale. }\end{array}$ & ence. & 111 amount & of $\mathrm{NaOH}$ & to match & $\begin{array}{l}\text { e been } \\
\text { total }\end{array}$ \\
\hline
\end{tabular}

The chemical analyses of burn pan residues are summarized in Table 8 for Test $A B 1$ and in Table 9 for Test AB2. Results for both tests show:

- Less than $50 \%$ of the metal reacted with oxygen during the 1-hr burn;

- The dominant oxide form was $\mathrm{Na}_{2} \mathrm{O}$, and

- When water vapor is present, appreciable amounts of $\mathrm{NaOH}$ may form. 
TABLE 9

CHEMICAL ANALYSIS OF BURN PAN RESIDUE - TEST AB2

\begin{tabular}{|c|c|c|c|c|c|c|c|}
\hline \multirow[b]{2}{*}{ Sample Number } & \multicolumn{6}{|c|}{ Weight Percent } & \multirow{2}{*}{$\begin{array}{l}\text { Total } \\
\text { Mass } \\
(\mathrm{kg}) \\
\end{array}$} \\
\hline & $\begin{array}{l}\text { Total } \\
\mathrm{Na} \\
\end{array}$ & $\begin{array}{l}\text { Metallic } \\
\mathrm{Na} \\
\end{array}$ & $\mathrm{Na}_{2} \mathrm{O}^{(a)}$ & $\mathrm{NaOH}^{(\mathrm{a})}$ & $\underline{\mathrm{Na}_{2} \mathrm{O}_{2}}$ & $\underline{\mathrm{Na}_{2} \mathrm{CO}_{3}}$ & \\
\hline \multicolumn{8}{|l|}{ OXIDE LAYER } \\
\hline $\mathrm{R} 2$ & 62.5 & 2.6 & - & - & 4.3 & 0.3 & \\
\hline R4 & 62.6 & 10.6 & - & - & 3.0 & 0.3 & \\
\hline R5 & 67.5 & 0.44 & - & - & 15.8 & 0.1 & \\
\hline R6 & 65.0 & 0.09 & - & - & 15.0 & 0.2 & \\
\hline AVERAGE & 64.4 & 3.43 & 31.3 & 55.6 & 9.52 & 0.23 & $153^{(b)}$ \\
\hline \multicolumn{8}{|l|}{ METALLIC LAYER } \\
\hline $\mathrm{RT}$ & 93.8 & - & - & - & 2.4 & - & \\
\hline R3 & 95.8 & - & - & - & 6.1 & - & \\
\hline AVERAGE & 94.8 & 82.5 & 13.3 & - & 4.2 & - & $349^{(b)}$ \\
\hline \multicolumn{8}{|l|}{ TOTAL BURN PAN } \\
\hline AVERAGE & 85.5 & 58.4 & 18.8 & 16.9 & 5.8 & 0.1 & $502^{(c)}$ \\
\hline $\begin{array}{l}\text { (a) Calculated b } \\
\text { value determ } \\
\text { (b) Estimated fr } \\
\text { made by scal } \\
\text { (c) Measured by }\end{array}$ & $\begin{array}{l}\text { differ } \\
\text { ned by } \\
\text { volum } \\
\text { cale. }\end{array}$ & $\begin{array}{l}\text { ence and } \\
\text { analysis. } \\
\text { and dens }\end{array}$ & $\begin{array}{l}\text { equiremen } \\
\text { ity and a }\end{array}$ & $\begin{array}{l}t \text { that } t \\
\text { djusted }\end{array}$ & a) $\mathrm{Na}$ & nust ec & $\begin{array}{l}\text { the } \\
\text { ght }\end{array}$ \\
\hline
\end{tabular}

\section{Analysis of Deposited Aerosol Mass}

Samples of oxide deposited on horizontal surfaces were taken from several locations in the vessel. Care was exercised to prevent exposure of the deposit to ambient air. Results obtained for Test $A B 1$ are 1 isted in Table 10, which also gives the results of the burn pan analysis. A breakdown to elemental masses is provided for burn pan residue, aerosol material (material deposited outside the burn pan), and the sum of the reaction products inside and outside the burn pan.

Perhaps the most striking feature of the analytical results presented in Table 10 is the difference in oxide forms found in the aerosol as opposed to forms in the burn pan. Virtually no $\mathrm{Na}_{2} \mathrm{O}$ was found outside the burn pan, suggesting that the source aerosol consisted of $\mathrm{Na}_{2} \mathrm{O}_{2}$ particles. The $\mathrm{Na}_{2} \mathrm{O}_{2}$ particles formed in the flame region, then reacted in the containment atmosphere with 
TABLE 10

\section{CHEMICAL FORM OF REACTION PRODUCTS - TEST ABT}

\begin{tabular}{|c|c|c|c|c|c|c|c|c|c|c|}
\hline Burn Pan & \multicolumn{2}{|c|}{$\frac{\text { Total Mass }}{(\mathrm{kg})}$} & \multicolumn{2}{|c|}{$\frac{\text { Equivalent } \mathrm{Na}}{(\mathrm{kg})} \frac{(\%)}{(\%)}$} & \multicolumn{2}{|c|}{$\frac{\text { Equivalent } 0}{(\mathrm{~kg})}$} & \multicolumn{2}{|c|}{$\frac{\text { Equivalent } \mathrm{H}}{(\mathrm{kg}) \quad(\%)}$} & \multicolumn{2}{|c|}{$\frac{\text { Equivalent } C}{(\mathrm{~kg})}$} \\
\hline Na Metal & 255.2 & 61.5 & 255.2 & 68.6 & 0.0 & 0.0 & 0.0 & - & 0.0 & 0 \\
\hline $\mathrm{Na}_{2} \mathrm{O}$ & 148.7 & 35.8 & 110.3 & .29 .7 & 38.4 & 89.2 & 0.0 & - & 0.0 & 0 \\
\hline $\mathrm{Na}_{2} \mathrm{O}_{2}$ & 9.1 & 2.2 & 5.4 & 1.5 & 3.73 & 8.7 & 0.0 & - & 0.0 & 0 \\
\hline $\mathrm{NaOH}$ & 0.0 & 0.0 & 0.0 & 0.0 & 0.0 & 0.0 & 0.0 & - & 0.0 & 0 \\
\hline $\mathrm{Na}_{2} \mathrm{CO}_{3}$ & 2.0 & 0.5 & 0.9 & 0.2 & 0.91 & 2.1 & 0.0 & - & 0.23 & 100.0 \\
\hline $\mathrm{H}_{2} \mathrm{O}$ & 0.0 & 0.0 & 0.0 & 0.0 & $\underline{0.0}$ & 0.0 & 0.0 & - & 0.0 & 0 \\
\hline TOTAL & 415.0 & 100.0 & 371.8 & 100.0 & 43.04 & 100.0 & 0.0 & - & 0.23 & 100.0 \\
\hline$\frac{\text { Aerosol }}{\text { (Outside Burn Pan) }}$ & & & & & & & & & & \\
\hline $\mathrm{Na}$ Metal & 0.0 & 0 & 0.0 & 0 & 0.0 & 0.0 & 0.0 & 0 & 0.0 & 0 \\
\hline $\mathrm{Na}_{2} \mathrm{O}$ & 0.0 & 0 & 0.0 & 0 & 0.0 & 0.0 & 0.0 & 0 & 0.0 & 0 \\
\hline $\mathrm{Na}_{2} \mathrm{O}_{2}$ & 19.4 & 26.8 & 11.4 & 28.5 & 8.0 & 26.0 & 0.0 & 0 & 0.0 & 0 \\
\hline $\mathrm{NaOH}$ & 48.8 & 67.5 & 28.1 & 70.4 & 19.5 & 63.5 & 1.22 & 77.7 & 0.0 & 0 \\
\hline $\mathrm{Na}_{2} \mathrm{CO}_{3}$ & 0.95 & 1.3 & 0.41 & 1.1 & 0.43 & 1.4 & 0.0 & 0 & 0.11 & 100.0 \\
\hline $\mathrm{H}_{2} \mathrm{O}$ & 3.15 & 4.4 & 0.0 & 0 & 2.80 & 9.1 & 0.35 & 22.3 & 0.0 & 0 \\
\hline TOTAL & 72.3 & 100.0 & 39.9 & 100.0 & 30.73 & 100.0 & 1.57 & 100.0 & 0.11 & 100.0 \\
\hline $\begin{array}{l}\text { Combined Total } \\
\text { Reaction Product } \\
\end{array}$ & & & & & & & & & & \\
\hline $\mathrm{Na}_{2} \mathrm{O}$ & 148.7 & 64.0 & 110.3 & 70.4 & 38.4 & 52.1 & 0.0 & 0 & 0.0 & 0 \\
\hline $\mathrm{Na}_{2} \mathrm{O}_{2}$ & 28.5 & 12.3 & 16.8 & 10.7 & 11.73 & 15.9 & 0.0 & 0 & 0.0 & 0 \\
\hline $\mathrm{NaOH}$ & 48.8 & 21.0 & 28.1 & 18.1 & 19.5 & 26.4 & 1.22 & 78.7 & 0.0 & 0 \\
\hline $\mathrm{Na}_{2} \mathrm{CO}_{3}$ & 2.95 & 1.3 & 1.31 & 0.8 & 1.34 & 1.8 & 0.0 & 0 & 0.34 & 100.0 \\
\hline $\mathrm{H}_{2} \mathrm{O}$ & 3.15 & 1.4 & 0.0 & 0.0 & 2.80 & 3.8 & 0.35 & 21.3 & 0.0 & 0 \\
\hline TOTAL & 232.1 & 100.0 & 156.51 & 100.0 & 73.77 & 100.0 & 1.55 & 100.0 & 0.34 & 100.0 \\
\hline
\end{tabular}

water vapor to form $\mathrm{NaOH}$. The observed chemical forms in the burn pan are consistent with known reactions between sodium metal and hydroxide and peroxide. $(18,19)$ In both cases the solid product is $\mathrm{Na}_{2} \mathrm{O}$.

Results of chemical analyses of deposited material for Test AB2 are given in Table 11. As expected, the steam added to the vessel atmosphere completely converted oxides to a sodium hydroxide solution; otherwise, the results of the two tests are quite comparable. 
TABLE 11

CHEMICAL FORM OF REACTION PRODUCTS - TEST AB2

\begin{tabular}{|c|c|c|c|c|c|c|c|c|c|c|}
\hline \multirow{2}{*}{ Burn Pan } & \multirow{2}{*}{$\frac{\text { Tota } 1}{(\mathrm{~kg})}$} & \multirow{2}{*}{$\frac{\text { Mass }}{(\%)}$} & \multicolumn{2}{|c|}{ Equivalent $\mathrm{Na}$} & \multicolumn{2}{|c|}{ Equivalent 0} & \multicolumn{2}{|c|}{ Equivalent $H$} & \multicolumn{2}{|c|}{ Equivalent $C$} \\
\hline & & & $(\mathrm{kg})$ & $(\%)$ & $(\mathrm{kg})$ & $(\%)$ & & $(\%)$ & & \\
\hline $\mathrm{Na}$ Metal & 293.2 & 58.4 & 293.2 & 68.3 & 0.0 & 0.0 & 0.0 & 0 & 0.0 & 0 \\
\hline $\mathrm{Na}_{2} \mathrm{O}$ & 94.4 & 18.8 & 70.0 & 16.3 & 24.4 & 34.7 & 0.0 & 0 & 0.0 & 0 \\
\hline $\mathrm{Na}_{2} \mathrm{O}_{2}$ & 29.1 & 5.8 & 17.2 & 4.0 & 11.9 & 16.9 & 0.0 & 0 & 0.0 & 0 \\
\hline $\mathrm{NaOH}$ & 84.8 & 16.9 & 48.8 & 11.4 & 33.9 & 48.1 & 2.1 & 100.0 & 0.0 & 0 \\
\hline $\mathrm{Na}_{2} \mathrm{CO}_{3}$ & 0.5 & 0.1 & 0.2 & 0.05 & 0.23 & 0.3 & 0.0 & 0 & 0.06 & 100.0 \\
\hline $\mathrm{H}_{2} \mathrm{O}$ & 0.0 & 0.0 & 0.0 & 0.0 & 0.0 & 0.0 & 0.0 & 0 & 0.0 & 0 \\
\hline TOTAL & 502.0 & 100.0 & 429.4 & 100.05 & 70.43 & 100.0 & 2.1 & 100.0 & 0.06 & 100.0 \\
\hline \multicolumn{11}{|l|}{ Aerosol } \\
\hline Na Metal & 0.0 & 0 & 0.0 & 0.0 & 0 & 0 & 0 & 0 & 0 & 0 \\
\hline $\mathrm{Na}_{2} \mathrm{O}$ & 0.0 & $\dot{0}$ & 0.0 & 0.0 & 0 & 0 & 0 & 0 & 0 & 0 \\
\hline $\mathrm{Na}_{2} \mathrm{O}_{2}$ & 0.0 & 0 & 0.0 & 0.0 & 0 & 0 & 0 & 0 & 0 & 0 \\
\hline $\mathrm{NaOH}$ & 66.4 & 59.3 & 38.2 & 99.0 & 26.6 & 40.0 & 1.66 & 25.1 & 0 & 0 \\
\hline $\mathrm{Na}_{2} \mathrm{CO}_{3}$ & 0.92 & 0.8 & 0.4 & 1.0 & 0.42 & 0.6 & 0.0 & 0 & 0.10 & 100.0 \\
\hline $\mathrm{H}_{2} \mathrm{O}$ & 44.6 & 39.9 & 0.0 & 0.0 & $\underline{39.6}$ & 59.4 & 4.96 & 74.9 & 0 & 0 \\
\hline TOTAL & 111.9 & 100.0 & 38.6 & 100.0 & 66.6 & 100.0 & 6.62 & 100.0 & 0.10 & 100.0 \\
\hline \multicolumn{11}{|l|}{$\begin{array}{c}\text { Combined Total } \\
\text { Reaction Product }\end{array}$} \\
\hline $\mathrm{Na}_{2} \mathrm{O}$ & 94.4 & 29.4 & 70.0 & 40.0 & 24.4 & 17.8 & 0.0 & 0 & 0.0 & 0 \\
\hline $\mathrm{Na}_{2} \mathrm{O}_{2}$ & 29.1 & $9: 1$ & 17.2 & 9.8 & 11.9 & 8.7 & 0.0 & 0 & 0.0 & 0 \\
\hline $\mathrm{NaOH}$ & 151.2 & 47.2 & 87.0 & 49.8 & 60.5 & 44.1 & 3.76 & 43.1 & 0.0 & 0 \\
\hline $\mathrm{Na}_{2} \mathrm{CO}_{3}$ & 1.42 & 0.44 & 0.6 & 0.34 & 0.65 & 0.5 & 0.0 & 0 & 0.16 & 100.0 \\
\hline $\mathrm{H}_{2} \mathrm{O}$ & 44.6 & 13.9 & 0.0 & 0 & 39.6 & 28.9 & 4.96 & 56.9 & 0.0 & 0 \\
\hline TOTAL & 320.7 & 100.04 & 174.8 & 99.94 & $137.05^{(a)}$ & 100.0 & $8.72^{b}$ & $\longdiv { 7 0 0 . 0 }$ & 0.16 & 100.0 \\
\hline
\end{tabular}

\section{Distribution of Deposited Aerosol Mass}

The distribution of deposited aerosol mass within the vessel was determined from analyses of settling trays and wall and horizontal surface washings. Settled masses measured by deposition trays at various locations in the vessel are presented in Table 12. Unshadowed surfaces collected $413 \pm 37.1 \mathrm{~g} / \mathrm{m}^{2}$ of sodium compared to $290 \pm 7.8 \mathrm{~g} / \mathrm{m}^{2}$ for shadowed surfaces. The shadowed collectors were located beneath the burn pan support plate on the vessel floor. 
TABLE 12

SETTLED MASS MEASURED BY DEPOSITION TRAYS - TEST AB1

\begin{tabular}{|c|c|c|c|c|}
\hline \multirow{2}{*}{$\begin{array}{l}\text { Tray (a) } \\
\text { Number }\end{array}$} & \multicolumn{2}{|c|}{ Unshadowed Surfaces } & \multicolumn{2}{|c|}{ Shadowed Surfaces } \\
\hline & $(\mathrm{g} \mathrm{Na}$ & $\left(\mathrm{g} \mathrm{Na/m^{2 } )}\right.$ & $(\mathrm{g} \mathrm{Na}$ & $\left(\mathrm{g} \mathrm{Na} / \mathrm{m}^{2}\right)$ \\
\hline D50 & 11.7 & 410 & & \\
\hline D51 & 10.9 & 382 & & \\
\hline D52 & 13.1 & 460 & & \\
\hline D53 & 11.8 & 414 & & \\
\hline D54 & 12.4 & 435 & & \\
\hline D55 & 13.2 & 463 & . & \\
\hline D56 & 10.4 & 365 & & \\
\hline D57 & 10.8 & 379 & & \\
\hline D58 & - & - & 8.42 & 295 \\
\hline D59 & - & $=$ & 8.08 & 284 \\
\hline MEAN & & 413 & & 290 \\
\hline$\sigma$ & & 37.7 & & 7.8 \\
\hline & & $( \pm 9.0 \%)$ & & $( \pm 2.7 \%)$ \\
\hline
\end{tabular}

$\overline{(a)} 275 \mathrm{~cm}^{2}$ of upward-facing horizontal surface.

They were located $0.61 \mathrm{~m}$ below an overhanging plate that protruded $25.4 \mathrm{~cm}$ beyond the outer rim of the collector tray. The fact that the shadowed collector accumulated nearly as much deposit as the unobstructed one shows that the gas phase was effectively mixed and that all horizontal surfaces collect particles by gravity settling. The masses of sodium collected by horizontal trays in Test $A B 2$ are listed in Table 13. The results for Test $A B 2$ are quite similar to those obtained in Test $A B 1$, as expected.

Aerosol mass plated on vertical wall surfaces was estimated on the basis of sodium dissolved from a representative area. Prior to the tests, it was hoped that the entire wall could be washed by spray after aerosol deposit had been washed from the vessel floor. Visual examination showed, however, that 
TABLE 13

SETTLED MASS MEASURED BY DEPOSITION TRAYS - TEST AB2

\begin{tabular}{|c|c|c|c|c|}
\hline $\begin{array}{l}\text { Tray (a) } \\
\text { Number }\end{array}$ & $\frac{\text { Unshado }}{(\mathrm{g} \mathrm{Na})}$ & $\frac{\text { Surfaces }}{\left(\mathrm{g} \mathrm{Na} / \mathrm{m}^{2}\right)}$ & $\begin{array}{l}\text { Shadowe } \\
(\mathrm{g} N \mathrm{Na})\end{array}$ & $\begin{array}{l}\text { Surfaces } \\
\left(\mathrm{g} \mathrm{Na} / \mathrm{m}^{2}\right)\end{array}$ \\
\hline D50 & 11.1 & 404 & & \\
\hline D51 & 7.20 & 262 & & \\
\hline D52 & 13.7 & 498 & & \\
\hline D53 & 24.4 & 887 & & \\
\hline D54 & 12.0 & 436 & & \\
\hline D55 & 10.2 & 371 & & \\
\hline D56 & 9.9 & 360 & & \\
\hline D57 & 15.0 & 545 & & \\
\hline D58 & - & - & 8.53 & 310 \\
\hline D59 & - & - & 8.78 & 319 \\
\hline MEAN & & 470 & & 315 \\
\hline$\sigma$ & & 189 & & 6.36 \\
\hline & & $( \pm 40 \%)$ & & $( \pm 2.0 \%)$ \\
\hline
\end{tabular}

$\sqrt{(a)} 275 \mathrm{~cm}^{2}$ of upward-facing horizontal surface.

this procedure would not yield satisfactory results because some horizontal surfaces would be washed by wall 1iquid. Because each horizontal surface was covered with surface densities 100 to 1000 times higher than the vertical surfaces, even a small horizontal surface would dominate compared to the washed vertical surface; therefore, removal of plated mass from a representative surface area had to be relied upon.

Sodium removed from a vertical patch is described in Table 14 . The most significant result evident in Table 14 is that the surface density of deposited sodium is less than $1 \%$ of the value for horizontal surfaces. 
TABLE 14

SODIUM PLATED ON VERTICAL WALL - TEST ABI

$\begin{array}{ll}\text { Area Decontaminated }\left(\mathrm{m}^{2}\right) & 0.042 \\ \text { Na Recovered }(\mathrm{g}) & 0.138 \\ \text { Density }\left(\mathrm{g} \mathrm{Na} / \mathrm{m}^{2}\right) & 3.3\end{array}$

The fractional distribution of sodium compounds on the various surfaces in the vesse 1 is presented in Table 15 for Test $A B 1$ and in Table 16 for Test AB2. As indicated, more than $90 \%$ of the aerosol was collected by horizontal surfaces even though such surfaces accounted for less than 10\% of the total exposed surface. Results for the two runs were quite similar.

TABLE 15

\section{DISTRIBUTION OF DEPOSITED SODIUM WITHIN CV - TEST ABT}

Horizontal Surface

CV Floor (horizontal projection) Safety Catch Pan and Personnel Deck A11 Other Horizonta] Surfaces TOTAL HORIZONTAL SURFACE

Vertical and Top Head Surface

Top Head

Vertical Wall

All Other Vertical Surfaces

TOTAL VERTICAL AND TOP HEAD SURFACE

TOTAL CONTAINMENT VESSEL
Recovered by Water Washes

\begin{tabular}{|c|c|c|c|}
\hline$\left(m^{2}\right)$ & $(\mathrm{kg} \mathrm{Na})$ & $(\%)$ & $\left(\mathrm{kg} \mathrm{Na} / \mathrm{m}^{2}\right)$ \\
\hline 37.2 & $17.6^{(a)}$ & & 0.473 \\
\hline 14.9 & $6.8^{(a)}$ & & 0.456 \\
\hline 35.9 & $12.5^{(b)}$ & & 0.348 \\
\hline 88.0 & $\overline{36.9^{(b)}}$ & 92.5 & 0.419 \\
\hline
\end{tabular}

\begin{tabular}{|c|c|c|c|}
\hline 60 & $0.20^{(c)}$ & & $0.0033^{(d)}$ \\
\hline 400 & $1.32^{(c)}$ & & $0.0033^{(\mathrm{e})}$ \\
\hline 450 & $1.49^{(c)}$ & & $0.0033^{(d)}$ \\
\hline 910 & 3.01 (c) & 7.5 & \\
\hline & $39.9^{(a)}$ & 100.0 & \\
\hline
\end{tabular}

\footnotetext{
(a) Measured by water wash volume and $\mathrm{Na}$ concentration.

(b) Calculated by difference.

(c) Calculated.

(d) Assumed to be same as for vertical wall.

(e) Measured by decontaminating known area of wall.
} 
TABLE 16

DISTRIBUTION OF DEPOSITED SODIUM WITHIN CV - TEST AB2

Horizontal Surface

CV Floor (horizontal projection)

Safety Catch Pan and Personnel Deck

A11 0ther Horizontal Surfaces

TOTAL HORIZONTAL SURFACE

Vertical and Top Head Surface

Top Head

Vertical Wall

Al1 Other Vertical Surfaces

TOTAL VERTICAL AND TOP HEAD SURFACE

TOTAL CONTAINMENT VESSEL

\begin{tabular}{cccc}
\multicolumn{4}{c}{ Recovered by Water Washes } \\
\hline$\frac{\left.(\mathrm{m})^{2}\right)}{37.2}$ & $\frac{(\mathrm{kg} \mathrm{Na})}{18.8^{(\mathrm{a})}}$ & $\underline{(\%)}$ & $\frac{\left(\mathrm{kg} \mathrm{Na} / \mathrm{m}^{2}\right)}{0.505}$ \\
14.9 & $4.4^{(\mathrm{a})}$ & & 0.295 \\
$\underline{35.9}$ & $\frac{12.7^{(\mathrm{b})}}{38.9^{(\mathrm{b})}}$ & & $\underline{0.354}$ \\
88.0 & 35.0 & 0.408
\end{tabular}

$\begin{array}{rrrr}60 & 0.18 & & 0.003^{(c)} \\ 400 & 1.20 & & 0.003^{(c)} \\ \frac{450}{910} & \frac{1.35}{2.73} & & 0.003^{(c)} \\ & \frac{7.0}{38.6^{(a)}} & \frac{700.0}{100.0}\end{array}$

(a) Measured by water wash volume and $\mathrm{Na}$ concentration.

(b) Calculated by difference.

(c) Assumed, based on visual observation and $A B 1$ result.

\section{Overall Sodium Balance}

An overall sodium mass balance was made to compare the mass of sodium delivered to the vessel with that accounted for in unburned sodium and in combustion products. Results for both tests are listed in Table 17. As indicated in this table, most of the sodium remained in the burn pan. The recovered sodium fully accounted for that delivered to the vessel. 
SODIUM INJECTION

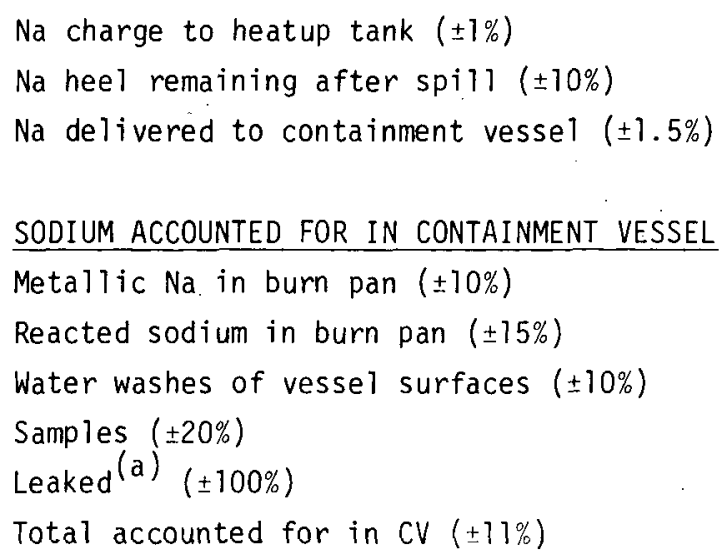

(a) Estimated. Chiefly due to sampling procedure.
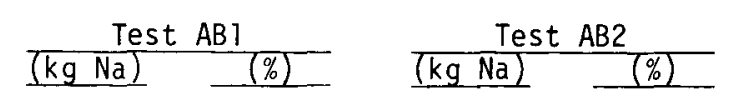

\begin{tabular}{|c|c|c|c|}
\hline 255 & 62.0 & 293 & 62.6 \\
\hline 117 & 28.3 & 136 & 29.1 \\
\hline 39.9 & 9.64 & 38.6 & 8.25 \\
\hline 0.2 & 0.05 & 0.2 & 0.043 \\
\hline 0.02 & 0.005 & 0.02 & 0.004 \\
\hline 412.12 & 99.995 & 467.82 & 99.997 \\
\hline
\end{tabular}

\section{ENERGY RELEASE AND SODIUM OXIDATION RATE}

\section{Thermal Energy Balance}

An energy balance was made by computing the sensible heat increase in

- the burn pan and its contents,

- the contained atmosphere, and

- the steel walls and internal structures of the vessel.

Because heat losses from the vessel exterior would be minor (estimated at <5\%) during the first 60 minutes; the energy released by the one-hour pool fire would be closely approximated by the sensible heat increases described above. 
Energy absorbed by the gas was computed from measured temperatures, an assumed heat capacity of $1000 \mathrm{~J} / \mathrm{kg} \mathrm{K}$, and a mass of air computed from the ideal gas law using measured values of temperature and pressure along with the known vessel volume. The average gas temperature was computed from readings of eight thermocouple located at several elevations in the vessel.

Steel ladders and other vessel internal structures exposed to the atmosphere were assumed to have the same average temperature as the atmosphere. The mass of steel in thermal equilibrium with the atmosphere was estimated to be $11,000 \mathrm{~kg}$.

Energy in the vessel outer wall was computed from the average temperature indicated by 11 thermocouples placed on the wall at various elevations. The steel mass was taken as $102,000 \mathrm{~kg}$, and the heat capacity of steel was assigned a value of $460 \mathrm{~J} / \mathrm{kg} \mathrm{K}$. Likewise, sensible energy in the sodium pool and burn pan were computed from measured temperatures, using a heat capacity of $1.26 \times 10^{3} \mathrm{~J} / \mathrm{kg} \mathrm{K}$ for sodium. The sodium mass was taken as that which was spilled.

Results of the sensible heat calculations for Test $A B 1$ are summarized in Table 18 and for Test $A B 2$ in Table 19. Figure 27 is a plot of total heat gained as a function of time.

The very rapid increase in sensible heat during the first minute suggests that burning was augmented by splashing during sodium delivery. For the remainder of the one-hour burn the heat addition rate gradually slowed, reflecting the reduced burning rate caused by oxygen depletion and crust formation and perhaps heat loss from the vessel walls.

As is shown by the curves of Figure 27, more energy evolved in Test $A B 2$. This increase may be attributed to the steam added during AB2. The steam apparently enhanced the burning rate so that slightly more sodium was reacted in Test $A B 2$ than in Test $A B 1$. 
TABLE 18

\section{SENSIBLE HEAT GAINS IN CSTF COMPONENTS} FOR TEST ABT

\begin{tabular}{|c|c|c|c|c|c|}
\hline & $\begin{array}{l}\text { Time From } \\
\mathrm{Na} \text { Spill1 } \\
\text { (min) }\end{array}$ & $\begin{array}{l}\text { Average Gas } \\
\text { Temperature } \\
\text { (K) }\end{array}$ & $\begin{array}{c}\text { Average Wa 1? } \\
\text { Temperature } \\
\text { (K) }\end{array}$ & $\begin{array}{c}\text { Average Na } \\
\text { Temperature } \\
\text { (K) }\end{array}$ & $\begin{array}{c}\text { Total Sensible } \\
\text { Heat Gain } \\
(\mathrm{J})\end{array}$ \\
\hline & 0 & 299.6 & 299.1 & 699.9 & 0 \\
\hline & 1.0 & 323.6 & 299.8 & 727.7 & $2.03(8)^{(a)}$ \\
\hline & 3.0 & 321.5 & 300.7 & 829.9 & $3.01 \quad(8)$ \\
\hline & 5.0 & 322.1 & 301.3 & 871.5 & $3.59(8)$ \\
\hline & 7.0 & 325.1 & 301.8 & 896.5 & $4.21 \quad(8)$ \\
\hline & 13.0 & 335.0 & 304.1 & 948.2 & $6.28(8)$ \\
\hline & 23.0 & 343.1 & 308.2 & 984.9 & $8.98(8)$ \\
\hline & 31.0 & 348.5 & 311.5 & 998.8 & $1.10(9)$ \\
\hline & 41.0 & 353.8 & 315.7 & 1011.5 & $1.34(9)$ \\
\hline & 60.0 & 364.1 & 323.9 & 1018.2 & $1.80(9)$ \\
\hline & 90.3 & 336.7 & 326.1 & 962.1 & $1.71(9)$ \\
\hline & 120.3 & 334.4 & 326.9 & 886.0 & 1.68 (9) \\
\hline & 156.2 & 331.1 & 327.4 & 810.4 & $1.64(9)$ \\
\hline & 180.15 & 332.8 & 327.5 & 762.1 & $1.60(9)$ \\
\hline & 240.1 & 331.6 & 327.8 & 701.5 & $1.55(9)$ \\
\hline
\end{tabular}

(a) Numbers in parentheses are exponents of base 10 ; i.e., read $2.03(8)$ as $2.03 \times 10^{8}$
TABLE 19

\section{SENSIBLE HEAT GAINS IN CSTF COMPONENTS} FOR TEST AB2

\begin{tabular}{|c|c|c|c|c|}
\hline $\begin{array}{l}\text { Time From } \\
\text { Na Spil1 } \\
\text { (min) }\end{array}$ & $\begin{array}{l}\text { Average Gas } \\
\text { Temperature } \\
\text { (K) }\end{array}$ & $\begin{array}{c}\text { Average Wall } \\
\text { Temperature } \\
\text { (K) }\end{array}$ & $\begin{array}{c}\text { Average } \mathrm{Na} \\
\text { Temperature } \\
\text { (K) } \\
\end{array}$ & $\begin{array}{c}\text { Total Sensible } \\
\text { Heat Gain } \\
\text { (J) }\end{array}$ \\
\hline 0 & 293.5 & 295.7 & 861.0 & 0 \\
\hline 1.5 & 331.0 & 299.1 & 888.8 & $4.21 \cdot(8)$ \\
\hline 7.5 & 333.1 & 301.3 & 946.0 & $5.83(8)$ \\
\hline 15.5 & 339.2 & 304.6 & 978.5 & $8.04(8)$ \\
\hline 25.5 & 347.6 & 309.5 & 998.5 & $1.11(9)$ \\
\hline 39.5 & 361.4 & 316.1 & 1004.7 & $1.50(9)$ \\
\hline 49.5 & 364.9 & 320.9 & 1006.5 & $1.75(9)$ \\
\hline 60.0 & 369.0 & 325.4 & 1006.9 & $2.00(9)$ \\
\hline 66.0 & 350.0 & 327.0 & 996.6 & $1.96(9)$ \\
\hline 71.0 & 346.1 & 327.4 & 979.8 & $1.94(9)$ \\
\hline 80.0 & 343.7 & 328.4 & 957.8 & $1.94(9)$ \\
\hline 90.0 & 341.0 & 328.6 & 942.0 & $1.92(9)$ \\
\hline 104.0 & 339.8 & 328.8 & 908.8 & $1.90(9)$ \\
\hline 120.0 & 338.9 & 329.1 & 870.4 & $1.88(9)$ \\
\hline 150.0 & 338.5 & 329.5 & 799.3 & $1.84(9)$ \\
\hline 180.0 & 337.3 & 329.8 & .745 .4 & $1.79(9)$ \\
\hline 240.0 & 335.7 & 329.9 & 662.6 & $1.72(9)$ \\
\hline
\end{tabular}




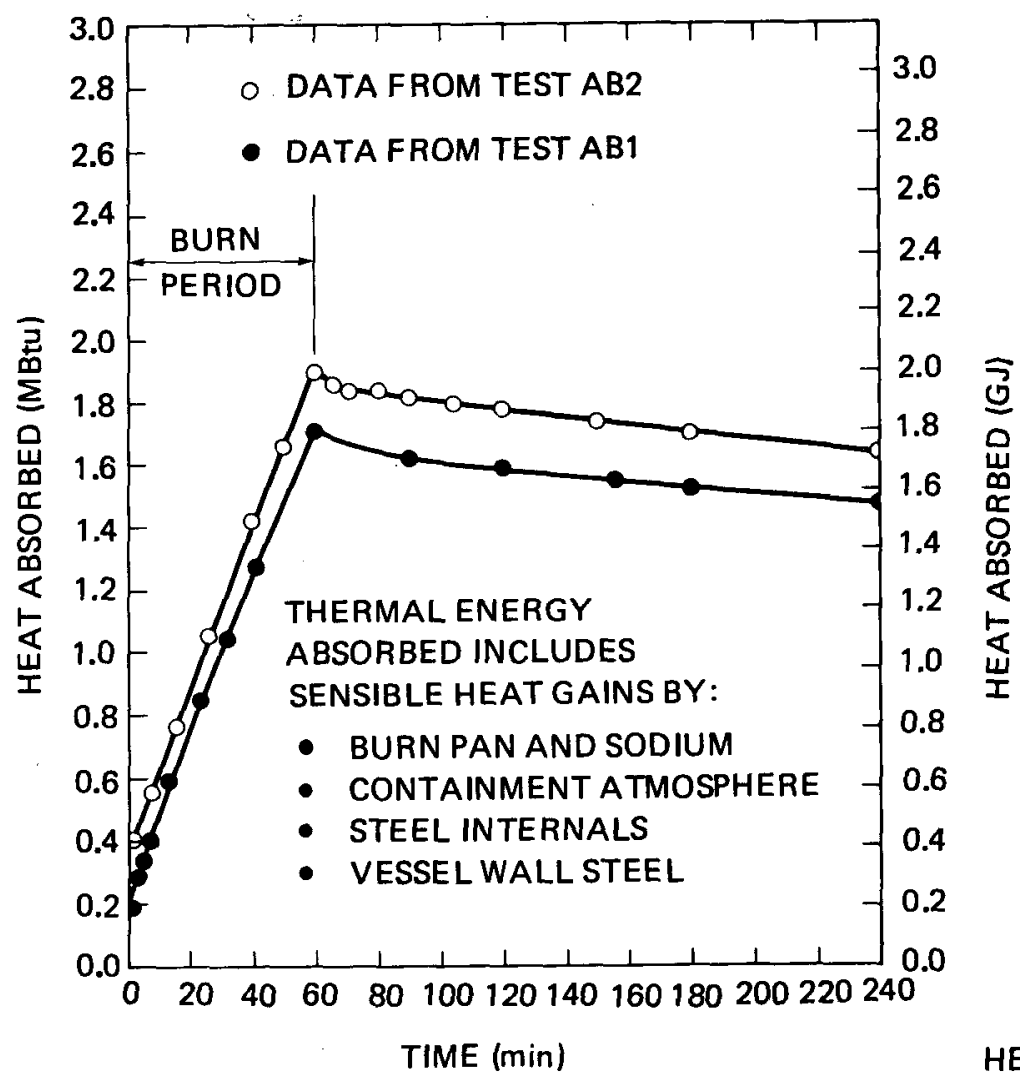

HEDL 7904-28.9

FIGURE 27. Sensible Heat of CSTF Vessel and Internals.

The heat energy evolved per unit mass of sodium combusted was calculated from the sensible heat gain at 60 minutes to be $11.5 \mathrm{MJ} / \mathrm{kg}$ in Test $A B 1$ and 11.5 $\mathrm{MJ} / \mathrm{kg}$ in Test $\mathrm{AB2}$. These energy releases agree well with estimated of 10.4 $\mathrm{MJ} / \mathrm{kg}$ and $13.2 \mathrm{MJ} / \mathrm{kg}$ based on thermochemical data ${ }^{(20)}$ and the material balances shown in Tables 10 and 11 (pages 50 and 51).

\section{Sodium Oxidation Rate}

The mean oxidation rate of sodium may be obtained by dividing the mass of sodium burned by the time period $(1 \mathrm{hr}$ ). If the oxidation rate is divided by the pool surface area $\left(4.38 \mathrm{~m}^{2}\right)$, the specific burning rate can be obtained. For $A B 1$, the mean burning rate was $35.7 \mathrm{~kg} \mathrm{Na} / \mathrm{hr} \mathrm{m}^{2}$ and for $A B 2$ it was 39.9 $\mathrm{kg} \mathrm{Na} / \mathrm{hr} \mathrm{m}^{2}$. 
The variation in burning rate with time can be computed from the energy release curves shown in Figure 27 if it is assumed that the heat given off per unit mass of sodium oxidized is constant. Burning rates computed on this basis are listed in Table 20 .

TABLE 20

SODIUM BURNING RATE VARIATION WITH TIME

\begin{tabular}{c}
$\frac{T}{(\min )}$ \\
\hline $0-10$ \\
$10-20$ \\
$20-30$ \\
$30-40$ \\
$40-50$ \\
$50-60$
\end{tabular}

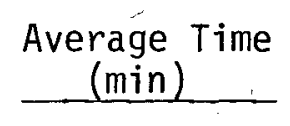

5

15

25

35

45

55
Burning Rate

\begin{tabular}{cc}
$\frac{\left(\mathrm{kg} / \mathrm{hr} \mathrm{m}^{2}\right)}{\mathrm{AB1}}$ & \multicolumn{1}{c}{$\mathrm{AB2}$} \\
\hline 60.2 & 79.4 \\
33.8 & 33.4 \\
33.2 & 33.4 \\
29.5 & 32.8 \\
28.9 & 31.5 \\
$\underline{28.9}$ & $\underline{29.0}$ \\
\hline 35.7 & 39.9
\end{tabular}

As indicated in Table 20, the initial burning rate was appreciably higher than the average rate. As oxygen became depleted, the burning rate fell as expected.

One expected influence of the high initial burning rate would be to give an early aerosol concentration appreciably higher than predicted on the basis of a linear release.

\section{Oxygen Consumption}

Oxygen consumption during the fire period was calculable from measured oxygen concentration in the containment atmosphere and the inventory of gas within the vessel. The latter was computed from temperature and pressure measurements, using the ideal gas law. 
Oxygen concentration was measured continuousiy by two identical monitors* that sampled atmosphere from two elevations in the containment vessel. Aerosol particles were removed by a filter in the sample line.

Oxygen concentrations measured during the pool fires are shown in Figure 28. As indicated on the figure, the average of two indicated readings is plotted as a function of time. Grab samples were withdrawn from sampling stations located high and low on the vessel wall, and these were analyzed by mass spectrometry. Grab sample results agreed well with the oxygen analyzer readings. Also, the samples obtained at the two elevations gave nearly identical results, showing that the containment atmosphere was well mixed.
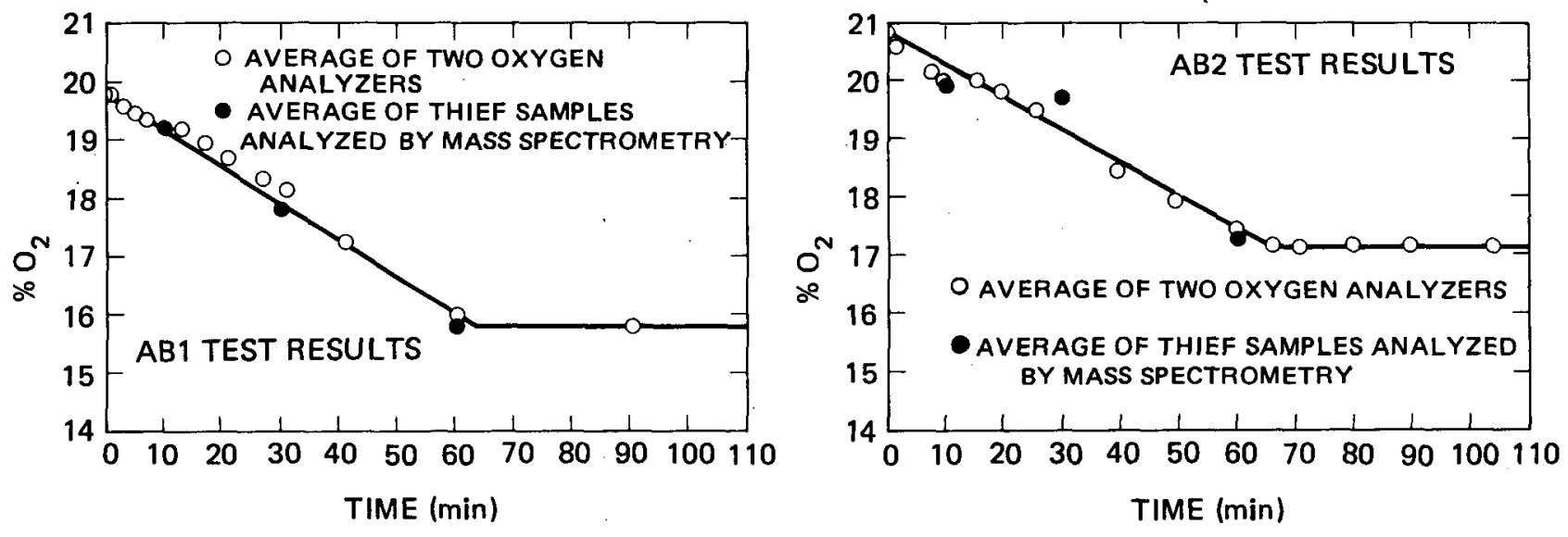

HEDL 7904-28.10

FIGURE 28. 0xygen Concentration During Sodium Fires.

The calculated mass of oxygen consumed by the pool fire in Test ABI is shown as a function of time in Figure 29. 0xygen consumption appears to be at maximum early (initial $4 \mathrm{~min}$ ) and then remains nearly linear with time for the remainder of the burn period. At the end of the burn period, the indicated oxygen consumption is $63.6 \mathrm{~kg}$, which compares well with the $60.3 \mathrm{~kg}$ based on the analysis of sodium combustion products shown in Table 10 (page 50).

ॠBeckman Instrument Corporation, Mode1 No. 7003, Fullerton, CA 92634. 


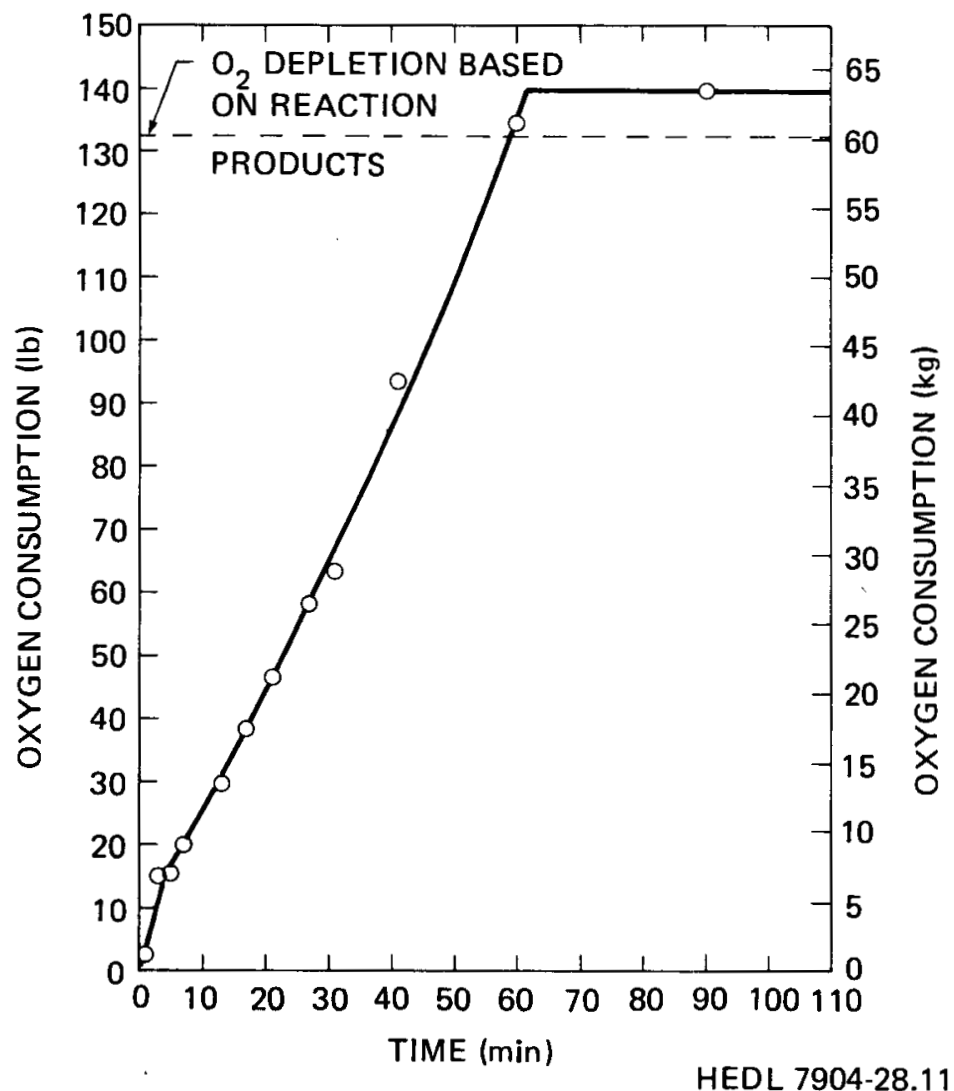

FIGURE 29. Oxygen Consumption Based on Measured $\mathrm{O}_{2}$ Concentration and Total Gas Mols in Test $A B 1$.

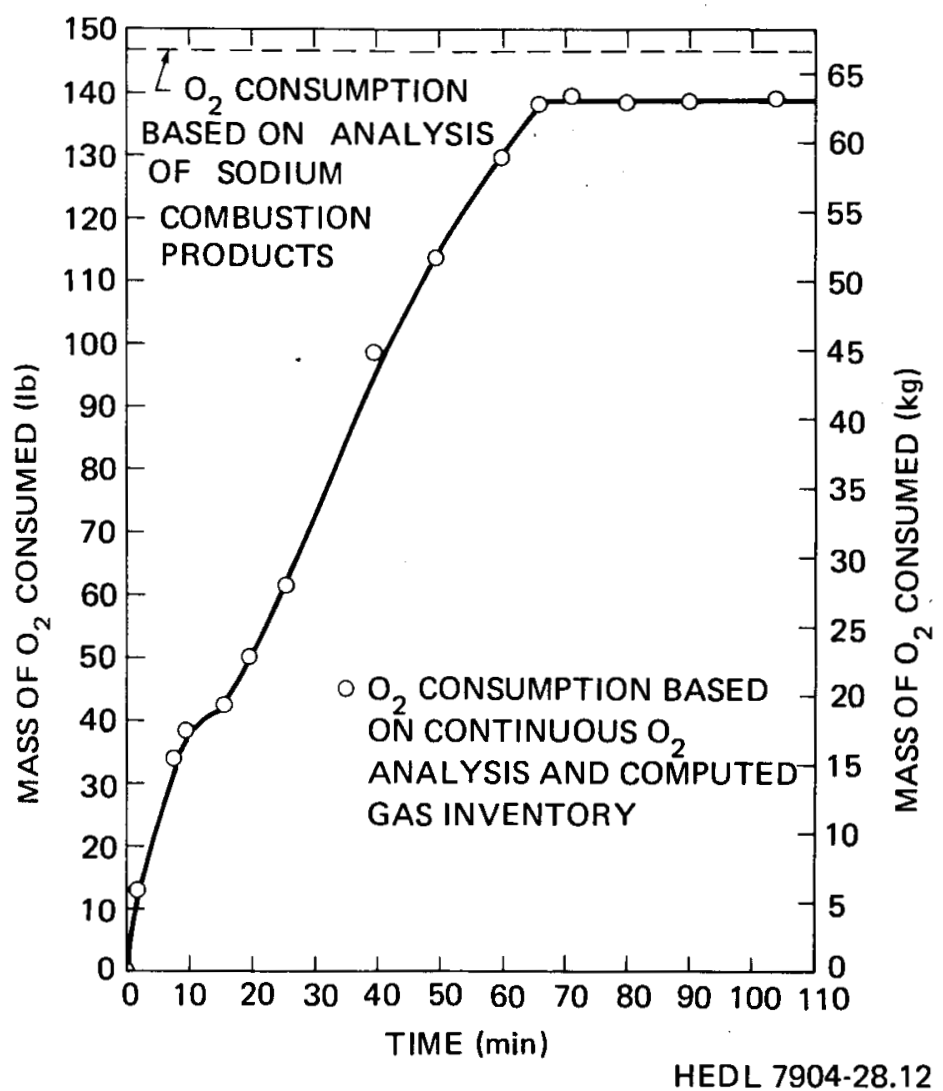

FIGURE 30. Oxygen Consumption Based on Measured $\mathrm{O}_{2}$ Concentration and Total Gas Mols in Test AB2. 
0xygen consumption in Test $A B 2$ is plotted versus time in Figure 30 . Results are similar to those for $A B 1$ except for an inflection point at about 15 minutes. The reduced slope of the curve may be caused by the introduction of steam, which would liberate oxygen from sodium peroxide aerosol. The final mass of oxygen consumed in AB2 was computed to be $63.05 \mathrm{~kg}$, which compares well with the $66.9 \mathrm{~kg}$ based on the analysis of sodium combustion products shown in Table 11 (page 51).

\section{Atmospheric Gas Composition}

During both tests, samples of the contained gases were withdrawn periodically and subjected to mass spectrometry analysis. Results are presented in Tables 21 and 22 for Tests $A B 1$ and $A B 2$, respectively. As expected, the results show the reduction in oxygen concentration, the increase in nitrogen and argon, and the negligible concentrations of $\mathrm{CO}, \mathrm{H}_{2}$, $\mathrm{He}$, and $\mathrm{CH}_{4}$.

TABLE 2$]$

COMPOSITION OF CONTAINMENT ATMOSPHERE - TEST ABT

\begin{tabular}{|c|c|c|c|c|c|c|c|c|c|c|}
\hline \multirow{2}{*}{$\begin{array}{c}\text { Time } \\
(\mathrm{s})\end{array}$} & \multirow{2}{*}{$\begin{array}{l}\text { Sample } \\
\text { Number }\end{array}$} & \multirow[b]{2}{*}{ Location (a) } & \multicolumn{8}{|c|}{ Mole Percent } \\
\hline & & & $\underline{O_{2}}$ & $\mathrm{~N}_{2}$ & $\mathrm{Ar}$ & $\mathrm{CO}_{2}$ & $\mathrm{CO}$ & $\mathrm{H}_{2}$ & He & $\mathrm{CH}_{4}$ \\
\hline$-7.80(3)^{(b)}$ & MSO & 2 & 19.8 & 79.2 & 0.89 & 0.05 & $<0.1$ & $<0,01$ & $<0.01$ & $<0.01$ \\
\hline $6.00(2)$ & MS1 & 1 & 19.2 & 79.8 & 0.94 & 0.03 & & & & \\
\hline $6.00(2)$ & MS2 & 2 & 19.1 & 79.9 & 0.94 & 0.03 & & & & \\
\hline $1.80(3)$ & MS3 & 1 & 17.8 & 81.3 & 0.95 & 0.03 & & & & \\
\hline $1.80(3)$ & MS4 & 2 & 17.8 & 87.2 & 0.95 & 0.03 & & & & \\
\hline $3.60(3)$ & MS5 & 1 & 15.7 & 83.2 & 0.97 & 0.02 & & & & \\
\hline $3.60 \quad(3)$ & MS6 & 2 & 15.8 & 83.2 & 0.98 & 0.02 & & & & \\
\hline $7.20(3)$ & MS7 & 1 & 16.5 & 82.1 & 1.41 & 0.04 & & & & \\
\hline $2.88(4)$ & MS9 & 1 & 15.2 & 82.8 & 1.98 & 0.03 & & & & \\
\hline $8.16(4)$ & MS10 & 2 & 14.8 & 83.1 & 2.05 & 0.02 & & & & \\
\hline $8.16(4)$ & MS11 & 1 & 14.7 & 83.2 & 2.04 & 0.02 & & & & \\
\hline $1.73(5)$ & MS 12 & 1 & 14.7 & 83.2 & 2.04 & 0.02 & $\downarrow$ & $\downarrow$ & $\downarrow$ & 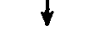 \\
\hline
\end{tabular}

(a) Location 1 is at elevation $+6.0 \mathrm{~m}$; location 2 is at elevation $-6.7 \mathrm{~m}$.

(b) Numbers in parentheses are exponents of base 10. 
TABLE 22

COMPOSITION OF CONTAINMENT ATMOSPHERE - TEST AB2

\begin{tabular}{|c|c|c|c|c|c|c|c|c|c|c|}
\hline \multirow{2}{*}{$\begin{array}{l}\text { Time } \\
(s) \\
\end{array}$} & \multirow{2}{*}{$\begin{array}{l}\text { Sample } \\
\text { Number } \\
\end{array}$} & \multirow{2}{*}{ Location (a) } & \multicolumn{8}{|c|}{ Mole Percent } \\
\hline & & & $\overline{0_{2}}$ & $\mathrm{~N}_{2}$ & $\mathrm{Ar}$ & $\mathrm{CO}_{2}$ & $\mathrm{CO}$ & $\mathrm{H}_{2}$ & $\mathrm{He}$ & $\mathrm{CH}_{4}$ \\
\hline$-1.80(3)^{(b)}$ & MSO & 2 & 20.9 & 78.1 & 0.93 & 0.06 & $<0.1$ & $<0.01$ & $<0.01$ & $<0.01$ \\
\hline $6.00(2)$ & MS ] & 1 & 19.7 & 79.7 & 1.16 & 0.02 & & & & \\
\hline $6.00 \quad(2)$ & MS2 & 2 & 20.0 & 78.9 & 1.74 & 0.03 & & & & \\
\hline $1.80(3)$ & MS3 & 1 & 18.7 & 80.1 & 1.17 & 0.02 & & & & \\
\hline $1.80(3)$ & MS4 & 2 & 20.7 & 78.3 & 0.98 & 0.05 & & & & \\
\hline $3.60(3)$ & MS5 & 1 & 17.2 & 81.6 & 1.20 & 0.03 & & & & \\
\hline $3.60(3)$ & MS6 & 2 & 17.4 & 81.4 & 1.19 & 0.02 & & & & \\
\hline $7.20(3)$ & MS7 & 1 & 16.9 & 81.8 & 1.19 & 0.02 & & & & \\
\hline $8.64(4)$ & MSIO & 2 & 16.6 & 82.1 & 1.20 & 0.03 & & & & \\
\hline $8.64(4)$ & MSII & 1 & 16.7 & 82.0 & 1.19 & 0.03 & & $t$ & $\downarrow$ & $\downarrow$ \\
\hline
\end{tabular}

(a) Location 1 is at elevation $+6.0 \mathrm{~m}$; location 2 is at elevation $-6.7 \mathrm{~m}$.

(b) Numbers in parentheses are exponents of base 10 . 


\section{COMPARISON OF SOFIRE-II CODE PREDICTIONS WITH EXPERIMENT}

The SOFIRE-II Code ${ }^{(21)}$ computes thermal conditions in a two-cell containment volume as a result of a sodium pool fire and other specified energy inputs. Test $A B 1$ was carried out under conditions where only one gas cell existed and where al1 thermal energy was derived from the fire. In Test AB2, steam was added and provided reaction energies and gas pressures not incorporated in SOFIRE-II; therefore, the comparisons presented in this section relate to Test $A B 1$ only.

\section{A. PRETEST PREDICTIONS}

A pretest run was made with the SOFIRE-II code to obtain estimates of the sodium burning rate, gas pressures, and temperatures inside the CSTF vessel. Pretest predictions of gas temperature in the CSTF are compared to experimental measurements in Figure 31.

The SOFIRE-II code overpredicted the gas temperature appreciably: The predicted temperature increase, $88 \mathrm{~K}$, is 1.34 times higher than the measured temperature increase of $66 \mathrm{~K}$.

Gas pressure predicted prior to the test is compared to measurements in Figure 32. The predicted pressure rise during the fire, $23.9 \mathrm{kPa}$, was 1.17 times greater than the measured pressure increase of $20.4 \mathrm{kPa}$.

The most notable discrepancy between the SOFIRE-II prediction and the test is the prediction of a pressure maximum at 0.6 hour; no maximum was observed in the test. The predicted maximum results from the competition between increasing pressure due to temperature rise and decreasing pressure due to oxygen consumption. Input parameters used for the pretest prediction are listed in Appendix D. 

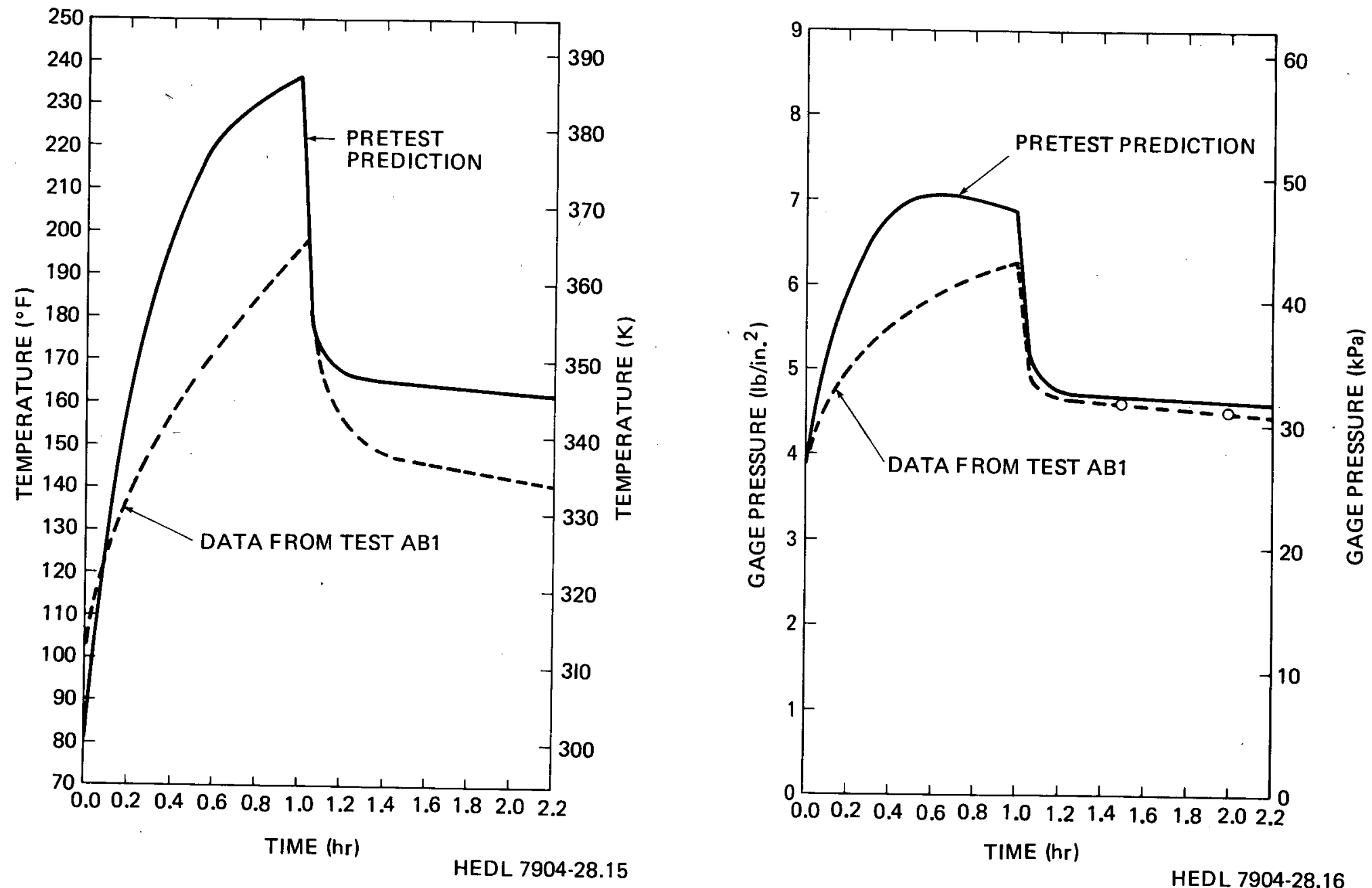

FIGURE 31. Comparison of Measured Gas Temperature With Pretest SOFIRE-II Prediction.

FIGURE 32. Comparison of Measured Gas Pressure With Pretest SOFIRE-II Prediction. 


\section{B. POSTTEST PARAMETER FIT}

The pretest prediction overestimated temperature and pressure in the containment vessel. This suggests that either the heat generation rate was overpredicted or that the heat losses or heat capacities were underpredicted. A careful examination of input parameters and vessel configuration brought to light that the original estimate of heat absorbing mass was low. Two other parameters that could be assigned more realistic values after the test were:

- Sodium/oxygen mass ratio and

- Heat of reaction.

These two parameters can be assigned values on the basis of the combustion product forms actually formed. Based on the combined reaction product forms listed in Table 10 (page 50), it was estimated that the sodium/oxygen mass ratio (ANA) was 2.12 and the heat of reaction (QC) was $10.4 \mathrm{MJ} / \mathrm{kg}$ of sodium. The posttest SOFIRE-II runs were made with these values of ANA and QC and the larger heat-absorbing mass of steel internal structure. Each input parameter used in the posttest SOFIRE-II run is given in Appendix D.

Gas temperatures predicted by the posttest SOFIRE-II run are compared with experimental measurements in Figure 33. It is apparent that the code appreciably overpredicted the contained gas temperature. In fact, the posttest prediction overpredicted gas temperatures by a greater margin than the pretest prediction.

Containment gas pressures predicted by the posttest SOFIRE-II run are compared with experimental measurements in Figure 34 . The predicted pressure increase is higher than measured, which is a reflection of the higher-than-predicted temperatures shown in Figure 33. The predicted maximum pressure at $0.5 \mathrm{hr}$ was not observed experimentally.

Several additional SOFIRE-II runs were made to help evaluate the reasons for the overprediction of containment temperature and pressure. Results from these supplementary runs showed that the input parameter ANA (sodium/oxygen 


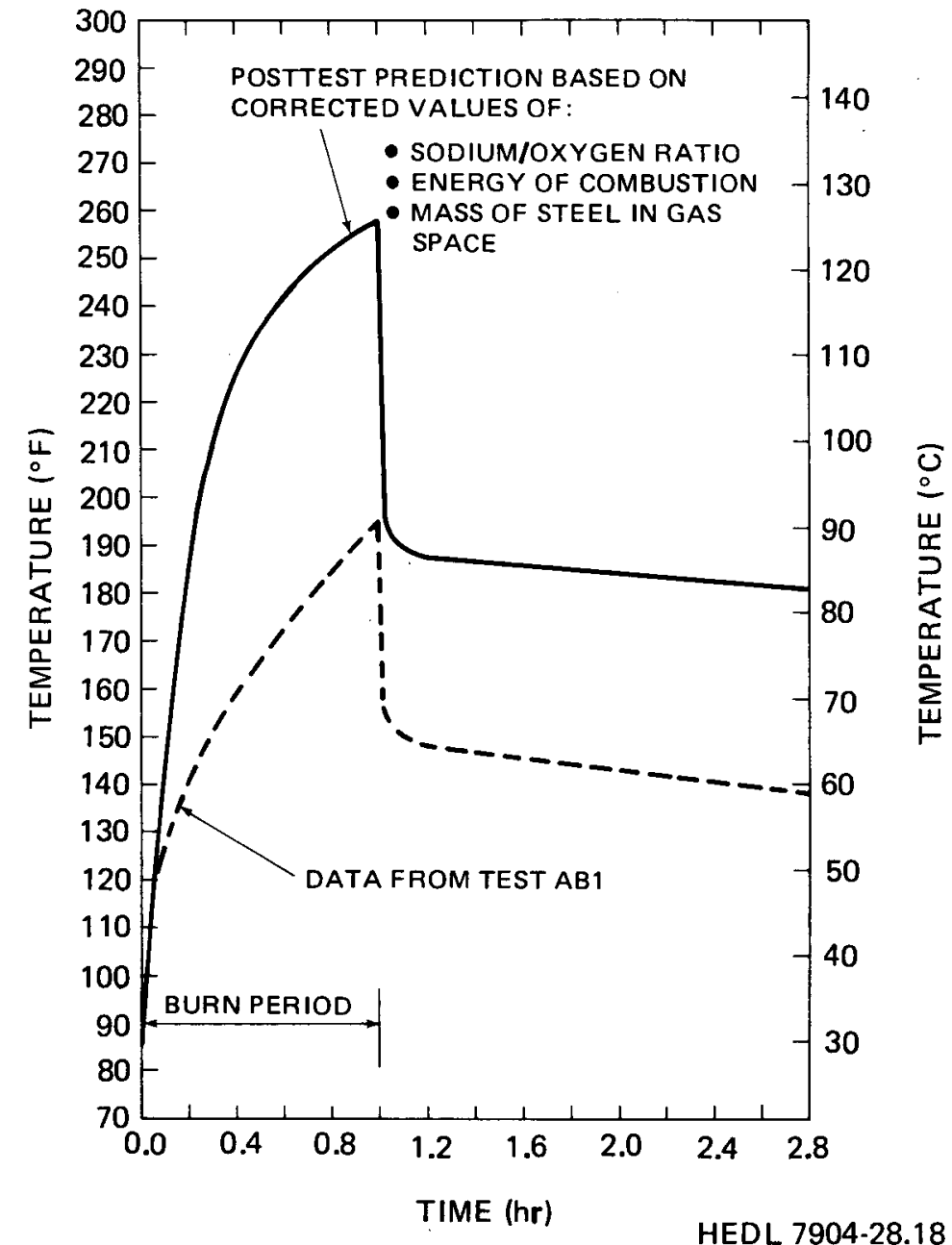

FIGURE 33. Comparison of Measured Gas Temperature With Posttest SOFIRE-II Predictions.

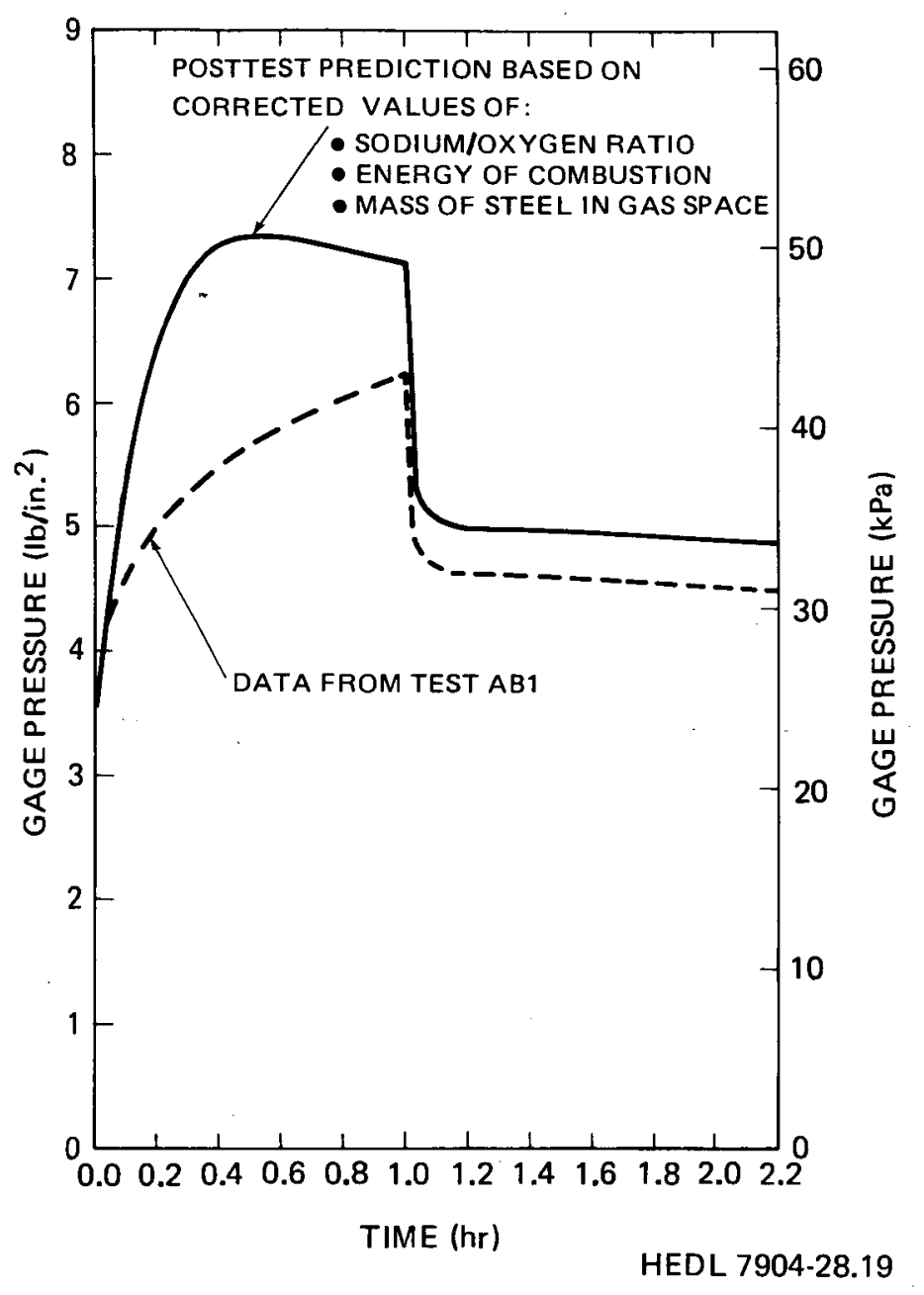

FIGURE 34. Comparison of Measured Gas Pressures With Posttest SOFIRE-II Predictions. 
mass ratio) was very important. The code calculational scheme is based on a burning rate limited by gas phase mass transfer of oxygen to the pool surface; therefore, the sodium combustion rate and, consequently, the energy release rate are almost linearly related to ANA. Smaller values of ANA would have led to a better fit of experiment and code predictions.

In addition to the atmosphere temperatures and pressures, a number of other predicted and measured quantities were compared to show how well the posttest SOFIRE-II run agreed with test results. Measured and predicted temperatures of the burn pan and sodium are plotted in Figure 35.

As expected, the burn pan and sodium were predicted to have similar temperatures. This followed from the high thermal conductivity of sodium and the relatively thin steel thickness $(4.8 \mathrm{~mm})$. The measured burn pan temperatures

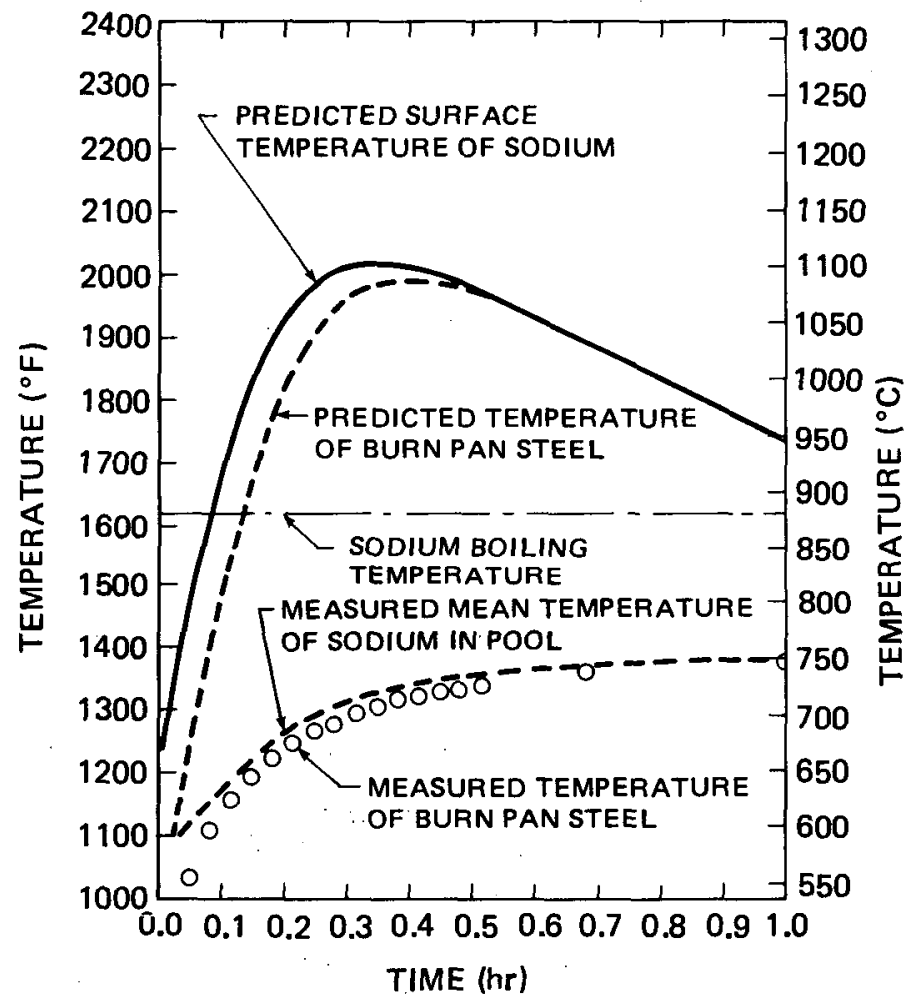

HEDL 7904-28.20

FIGURE 35. Comparison of Measured and Predicted Sodium Temperatures in Test $A B 1$. 
were significantly lower than the predicted temperatures; indeed, sodium temperatures predicted by the SOFIRE-II code rose well above the boiling point of sodium, revealing an obvious anomaly in the code.

Several important sodium fire parameters are listed in Table 23 along with predicted and measured values. Predicted values of sodium reacted and oxygen consumed are roughly 1.5 times greater than measured. Smaller values of input parameter ANA would have improved the fit between theory and experiment.

TABLE 23

COMPARISON OF POSTTEST SOFIRE-II CODE PREDICTIONS

WITH ABI TEST RESULTS

Parameter

Sodium reacted $(\mathrm{kg})$

Oxygen consumed $(\mathrm{kg})$

Sodium oxide aerosol produced $(\mathrm{kg})$

Fraction of burned sodium aerosolized

Maximum pressure increase in CSTF atmosphere ( $\mathrm{kPa}$ )

Temperature increase in CSTF atmosphere (K)
SOFIRE-II Experiment 154

73.5

0.19

27.2

100.4
0.26

20.4

65.8

The mass of aerosol produced in the test agreed quite well with the posttest prediction, but this may have been fortuitous. If smaller values of ANA had been used, the mass of sodium reacted would have been decreased and the predicted aerosol mass would have likewise decreased.

Much more work needs to be done to improve the fit between the SOFIRE-II predictions and the large-scale pool fire test results. Areas needing improvement are

- Heat transfer from pool surface to gas,

- Phase change at sodium boiling point,

- Secondary reactions with $\mathrm{O}_{2}$ and $\mathrm{H}_{2} \mathrm{O}$ vapor, and

- ANA (the sodium/oxygen mass ratio). 


\section{COMPARISON OF AEROSOL COMPUTER CODES WITH EXPERIMENT}

\section{A. PRETEST PREDICTIONS}

Pretest predictions of aerosol behavior were made using the $\mathrm{HAA}-3 \mathrm{~B}{ }^{(22)}$ and HAARM-3 ${ }^{(23)}$ computer codes. Predictions of test results were useful in planning the sampling schedule. Predictions are also more suitable for critically evaluating the codes than are posttest data fits because selection of code input parameters may strongly influence the predictions.

The aerosol generation rate is an input parameter in the HAA-3B and HAARM-3 codes. Pretest estimates of the aerosol generation rate were made by assuming that a constant fraction of the burned sodium evolved as an aerosol. Sodium burning rates were predicted by the SOFIRE-II code.

\section{Airborne Mass Concentration}

Airborne mass concentration predicted by the HAA-3B code prior to test completion is exhibited in Figure 36. As indicated, the fraction of burned sodium emitted as an aerosol was treated as a parameter and was varied from 10 to $40 \%$. Sodium burning rates calculated from the SOFIRE-II code, multiplied by a 10\% aerosolization factor, are 1isted in Table 24. The aerosol source rates corresponding to the four curves of Figure 36 are multiples $(1,2,3$, and 4 ) of the source rate 1 isted in Table 24 .

Based on data from earlier sodium fire tests, (24) it was anticipated that somewhere between 20 and $30 \%$ of burned sodium would be released from the pool as an aerosol.

From the comparison of predicted and measured concentrations shown in Figure 36, generally good agreement is apparent. At early times $(<1000 \mathrm{~s})$ the code underpredicted the concentration. This discrepancy can be attributed mainly to uptake of water vapor by particles of $\mathrm{Na}_{2} \mathrm{O}_{2}$. Test $A B 2$ results fall above the predictions after the aerosol source was terminated. Water vapor uptake 


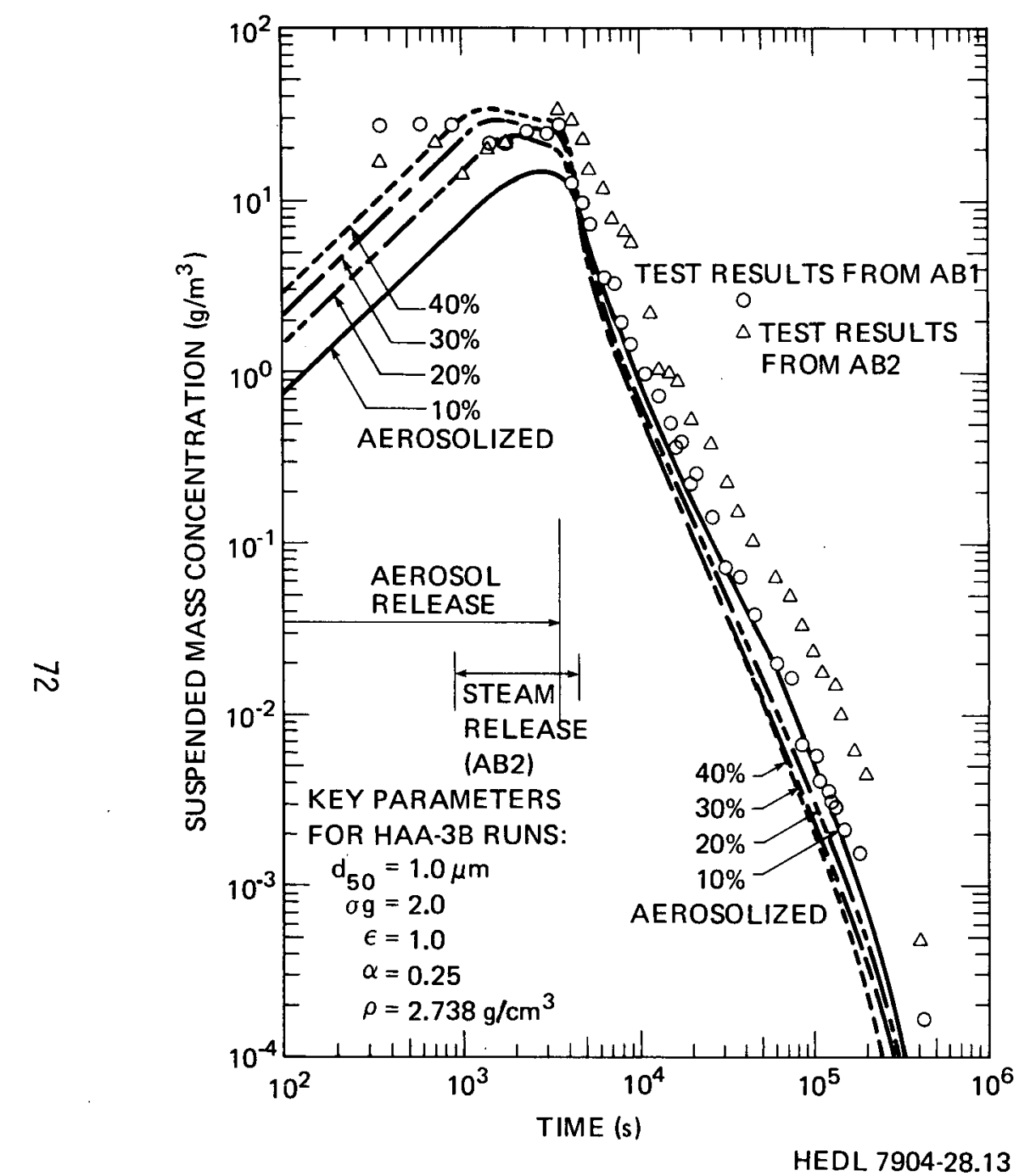

FIGURE 36. Pretest Predictions Made by the HAA-3B Code.

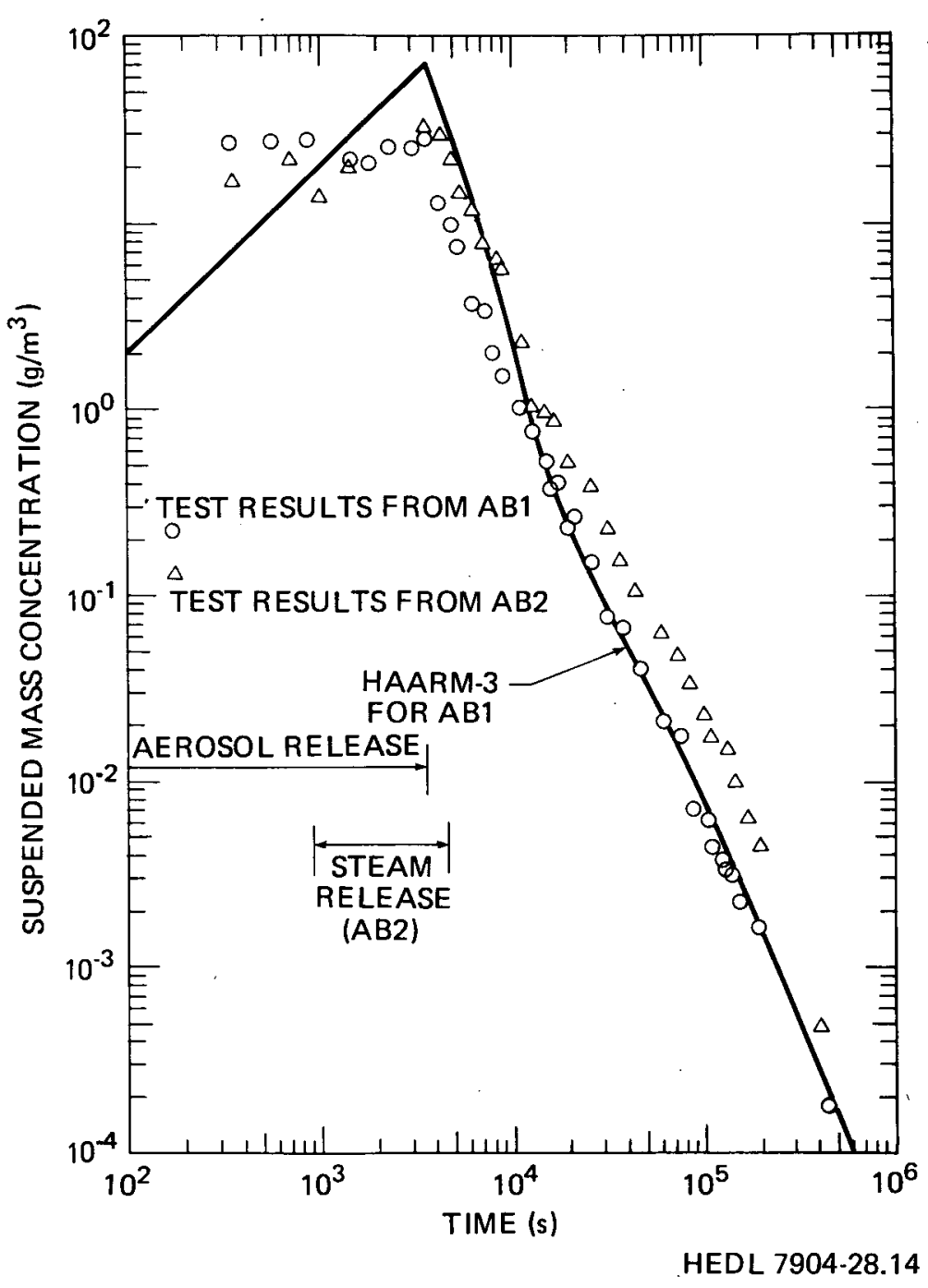

FIGURE 37. Pretest Predictions Made by the HAARM-3 Code. 


\section{AEROSOL GENERATION RATE CALCULATED} FOR $10 \%$ AEROSOLIZATION

\begin{tabular}{cc}
$\begin{array}{r}\text { Time } \\
(\mathrm{s})\end{array}$ & $\begin{array}{c}\text { Aerosol Generation Rate } \\
(\mathrm{g} / \mathrm{s})\end{array}$ \\
\hline 0 & 6.36 \\
180 & 6.70 \\
360 & 7.74 \\
540 & 7.40 \\
720 & 7.47 \\
900 & 7.41 \\
1080 & 7.26 \\
1440 & 6.81 \\
1800 & 6.30 \\
3600 & 4.13
\end{tabular}

caused a more rapid fallout during the fire period and, based on sodium released as an aerosol, a slightly higher attenuation factor was achieved by settling in $A B 2$ than' in $A B 1$.

Input parameters used for the pretest predictions made with the HAA-3B code are Tisted in Appendix D.

Predicted mass concentrations based on the HAARM-3 code are compared to test results in Figure 37 . The predicted curve is quite similar to the HAA-3B predictions shown in Figure 36. Overa17, the predicted and measured concentrations are in good agreement. The code underpredicts mass concentration at time periods shorter than 1000 seconds. Also, the code overpredicts the maximum concentration attained at the end of the fire.

After the aerosol source was terminated, HAARM-3 predictions agreed well with $A B 1$ test results. For times longer than $10^{4}$ seconds, the airborne concentrations measured in Test AB2 were higher than predicted. Most of the discrepancy between theory and experiment can be attributed to water vapor uptake. 


\section{Mass Leaked From Vessel}

The most important function of an aerosol behavior model is prediction of the mass of material that could leak from a vessel over a specified time period; therefore, the most sensitive test of code adequacy is its ability to correctly predict leaked mass. Leaked mass was computed from the measured concentrations in both tests using

$$
\text { Mass Leaked }={ }_{0} \int^{t} \mathrm{QC}_{g} d t
$$

Where:

$$
\begin{aligned}
Q & =\text { Leak flow rate }\left(\mathrm{m}^{3} / \mathrm{s}\right), \\
C_{g} & =\text { Airborne mass concentration }\left(\mathrm{g} / \mathrm{m}^{3}\right), \text { and } \\
\mathrm{t} & =\text { Time }(\mathrm{s}) .
\end{aligned}
$$

Leak flow rate $Q$ was arbitrarily assigned a value of $0.1 \%$ of contained gas volume per day, and decontamination within the leak path was neglected in the calculations of leaked mass presented herein. Equation (5) was numerically evaluated from smoothed data represented by the curves shown in Figure 17 and 18 (pages 33 and 36).

In Figure 38, leaked mass computed from test results is compared with predictions from the HAA-3B code. Good agreement between code predictions and test results is apparent.

When compared on the basis of total aerosol mass, leaked mass was calculated to be as much as 1.6 times higher in Test $A B 2$ than in $A B 1$; however, when compared on a sodium mass basis, leaked mass in Test $A B 2$ was computed to be 25\% lower than in $A B 1$. Thus, the added water in Test $A B 2$ enhanced the removal rate for aerosolized sodium even though the total leaked mass was higher in the wet test. 


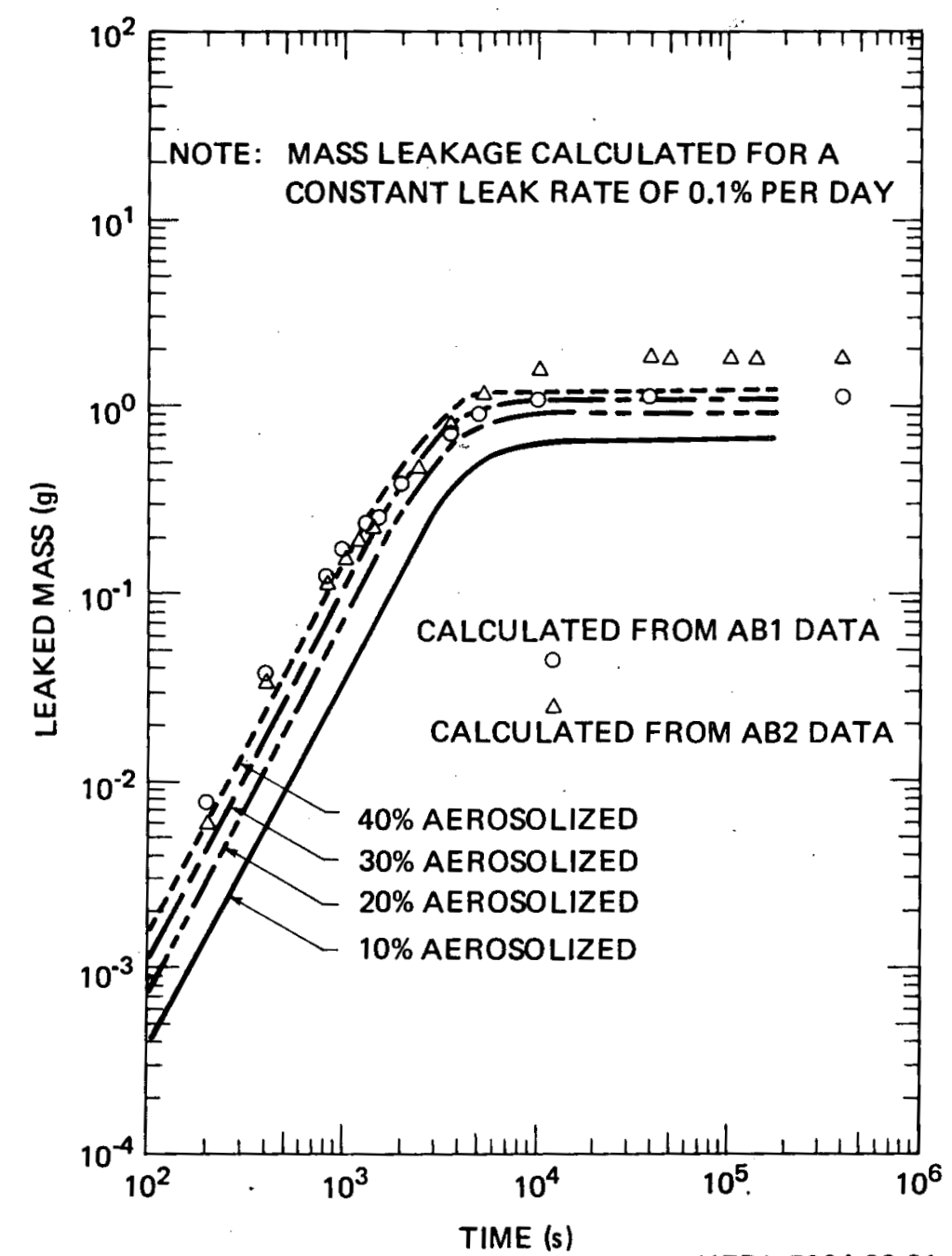

HEDL 7904-28.21

FIGURE 38. Pretest Prediction of Leaked Mass Based on the HAA-3B Code.

HAARM-3 predictions of leaked mass are compared with experiment data in Figure 39. For time periods greater than one hour, the code prediction is conservative when compared with the experiments. For long time periods, the predicted mass leaked is 1.6 times higher than $A B 2$ results and 2.7 times higher than indicated by $A B 1$ data. The overprediction of the HAARM- 3 code reflects the peak in the predicted concentration curve (exhibited in Figure 37, page 76), which is 2.5 times higher than the measured concentration peak. 


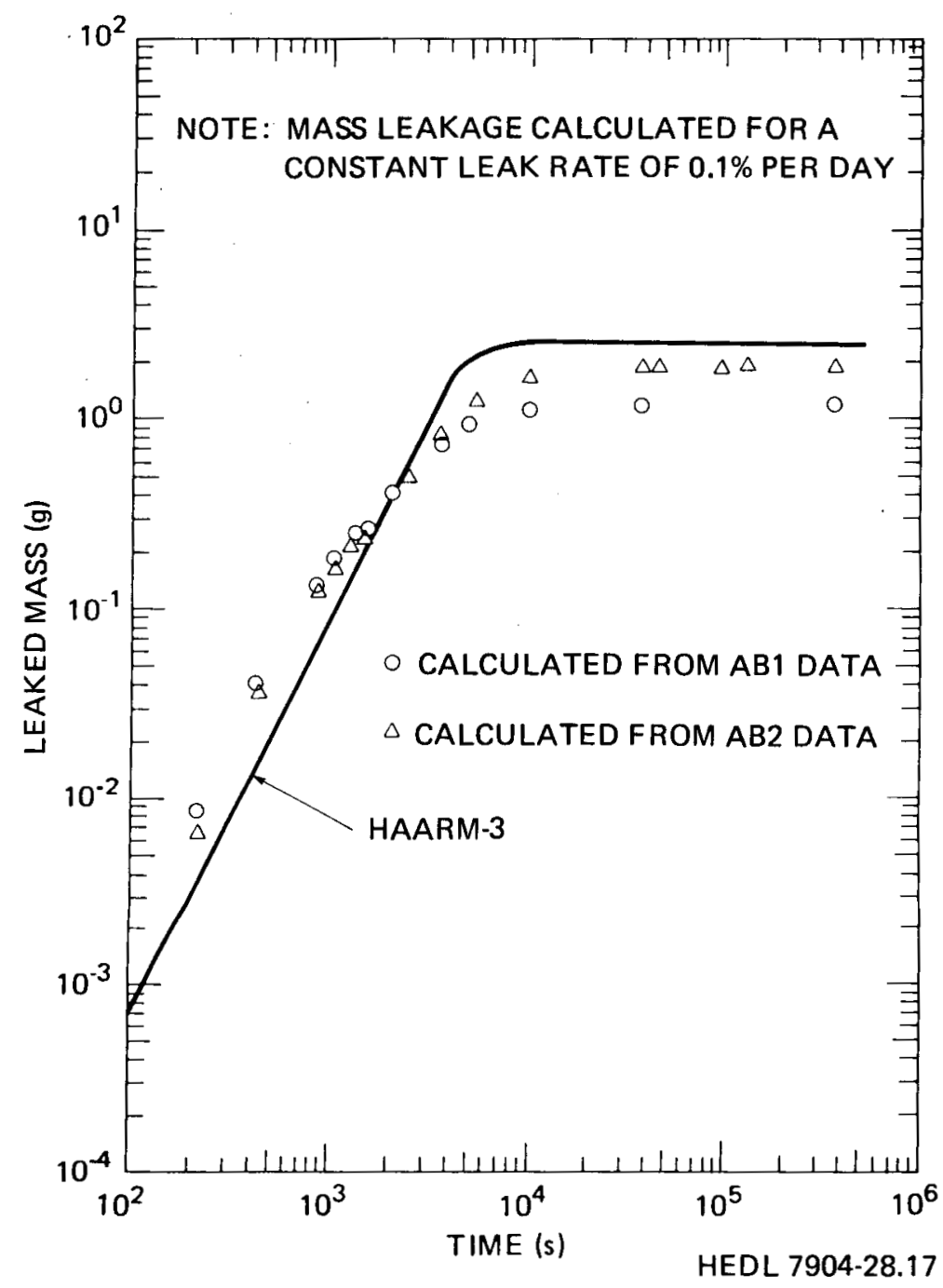

FIGURE 39. Pretest Prediction of Leaked Mass Based on HAARM-3 Code.

It is concluded that both the HAA-3 and HAARM-3 codes yielded good predictions of aerosol behavior in the large-scale pool-fire tests. Discrepancies can be mainly attributed to uptake of water vapor and to errors in pretest estimates of the aerosol generation rate.

\section{B. POSTTEST PARAMETER FIT}

Following completion of the two tests, a number of parametric runs were made with the HAA-3B code to determine what values of input parameters would optimize agreement between the code and large-scale test results. 


\section{Floor Area of Vessel}

The projected area of the CSTF vessel is the minimum floor area that would collect particles by gravity settling. Projected floor area has often been used in containment calculations, with other horizontal surfaces being neglected. Numerically, extraneous horizontal surface areas may not be small compared to the projected area; for example, the horizontal projection of equipment (1adders, walkways, etc.) in CSTF was estimated to be $42.3 \mathrm{~m}^{2}$, which is comparable to the vessel area of $45.7 \mathrm{~m}^{2}$.

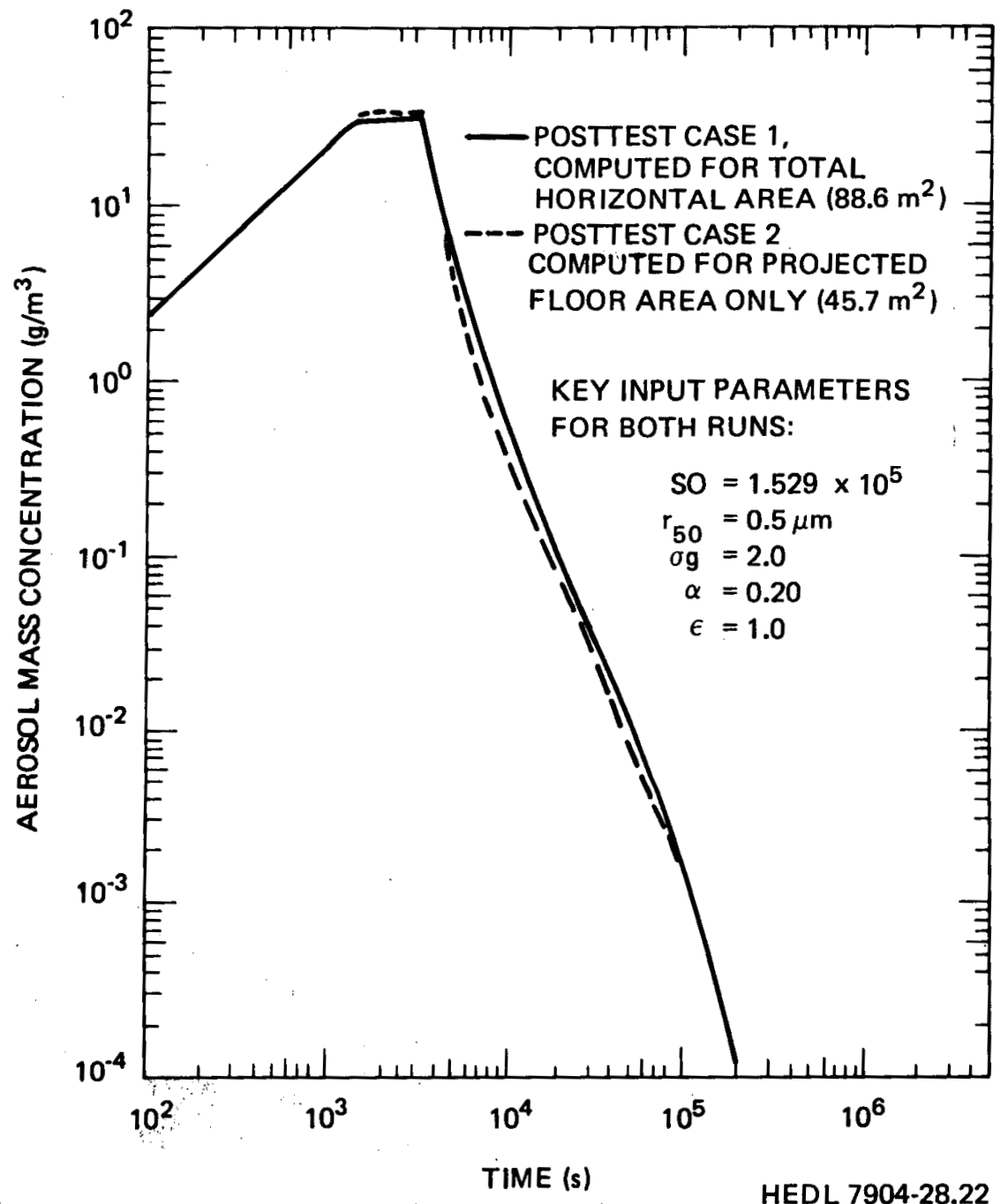

FIGURE 40. Effect of Horizontal Area on Predicted Aerosol Concentration. 
Because gravity settling is a dominant aerosol removal process in the $\mathrm{HAA}-3 \mathrm{~B}$ code, horizontal surface area was thought to be an important input variable. HAA-3B runs were carried out using both the projected area and the total areas. Predicted concentrations are presented in Figure 40. Surprisingly, since the floor area varied from 45.7 to $88.6 \mathrm{~m}^{2}$, the predicted concentration varied only slightly. In the case that used the smaller area, the maximum concentration reached a slightly higher value, but after the source terminated the concentration fell below the value for the larger surface area.

A plot of leaked mass for these two cases, presented in Figure 41, confirms the predicted negligible effect of floor area for the conditions tested. For times near the peak in airborne concentration, leaked mass was slightly higher for the smaller floor area case. Within a few hours of the peak, leaked mass became equal for the two cases. For accidents involving a long-term source release, the difference in leaked mass would be greater.

For the CSTF pool-fire cases, it was concluded that the floor area was not a sensitive parameter; however, because all horizontal surfaces collected particles, the total surface area was used in subsequent HAA-3B runs and is recommended for use by other analysts.

Input parameters used for 271 posttest $H A A-3 B$ runs are 1 isted in Appendix $D$. Case numbers are identified with each run to aid the reader in matching listed input parameters with plots presented in this report section.

\section{Initial Particle Size}

The size of particles emitted from the burning surface is an input parameter in both the HAA-3B and HAARM-3 codes. Earlier tests of aerosol behavior at Atomics International (22) showed that predictions and experiments were in good agreement when the source size was characterized by a 1-um mass median diameter and a log-normal standard deviation of 2.0 . 


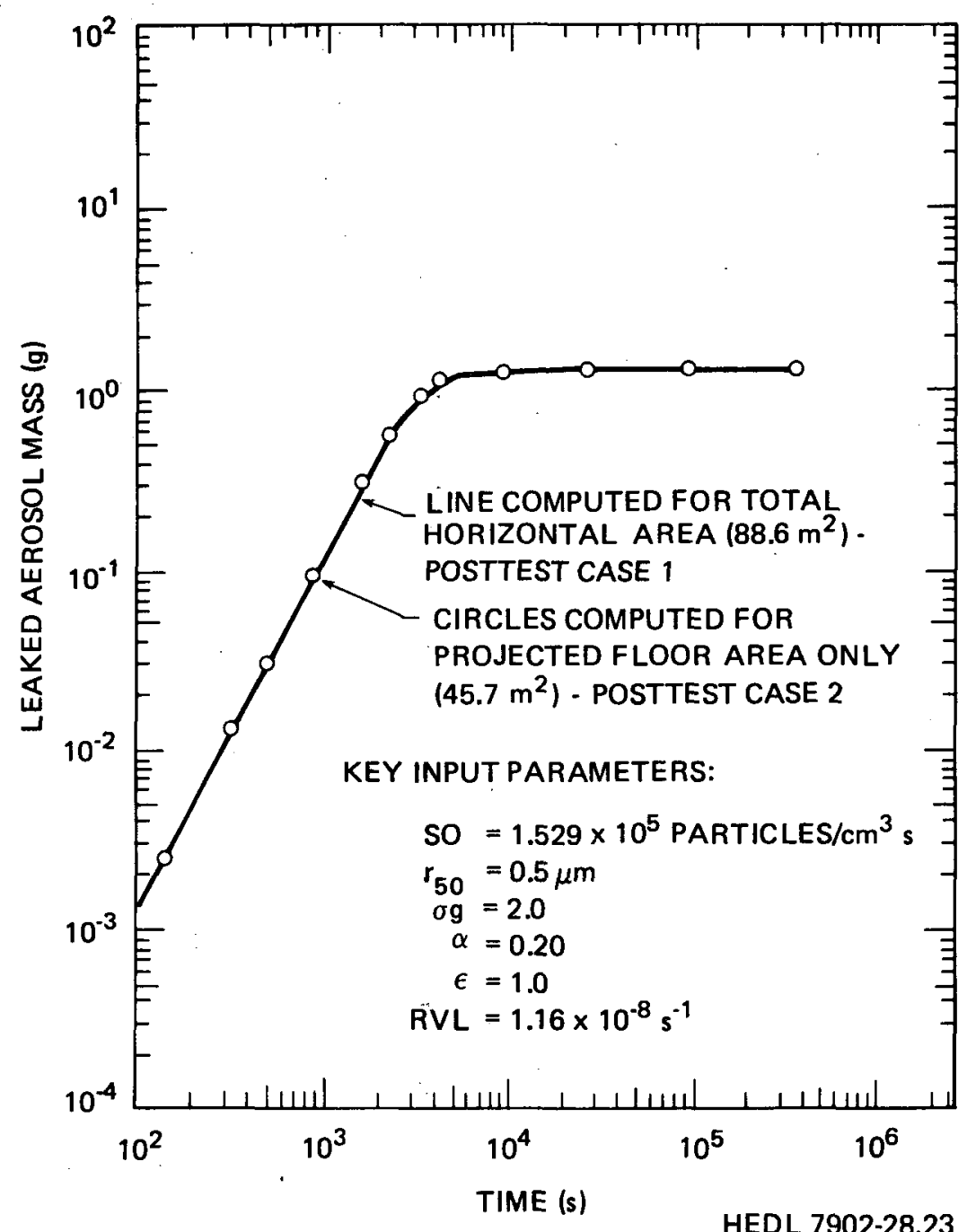

FIGURE 41. Predicted Effect of Horizontal Settling Area on Leaked Mass.

Available aerosol codes are based on an assumption of perfect mixing in the gas phase. Thus, primary particles from the source are presumed to be equally distributed within each cubic centimeter of gas in the vessel. This approach neglects the presence of high concentration regions over the burning surface and a thermally generated plume that rises from the burn pan. Agglomeration of particles in this high concentration region is thus neglected.

Several parametric runs were carried out with the HAA-3B code to determine how important the initial particle size was for CSTF pool-fire predictions. Results of runs made for $A B I$ conditions for source particle diameters of 0.5 , 
1.0, and $2.0 \mu \mathrm{m}$ are shown in Figure 42. It is apparent that slightly higher peak concentrations are calculated for smaller source particles; however, after the source is terminated predicted concentrations for the three cases merge.

For all three cases shown in Figure 42, leaked masses reached their upper asymptote after about $10^{4}$ seconds. Predicted aerosol masses leaked for the three cases are listed in Table 25.

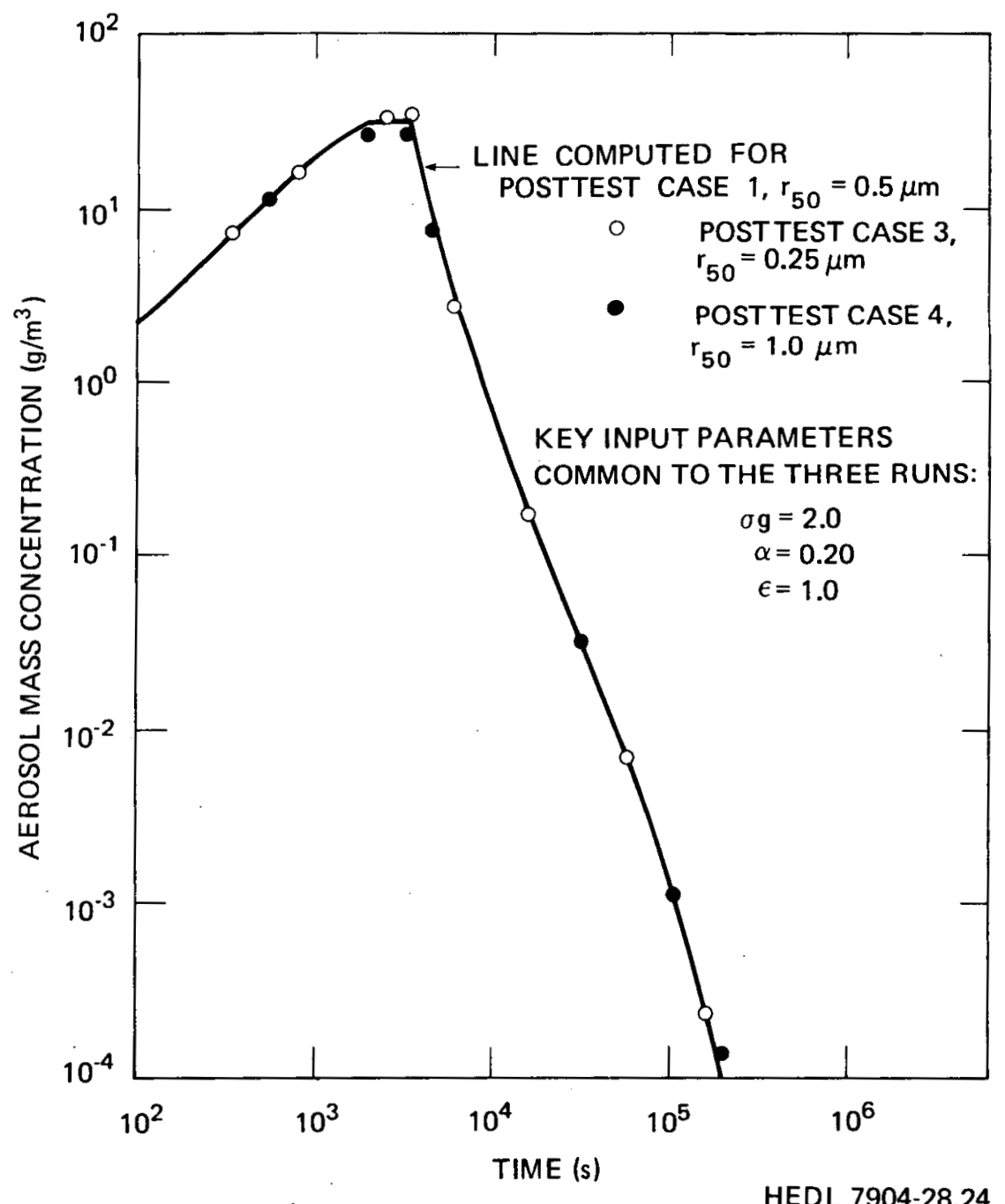

FIGURE 42. Effect of Source Particle Size on Predicted Aerosol Concentration. 
TABLE 25

EFFECT OF SOURCE PARTICLE SIZE ON LEAKED MASS

Source Diameter

$(\mu \mathrm{m})$

0.5

1.0

2.0
Leaked Aerosol Mass

(g)

1.30

1.27

1.16

Increasing the source particle size by a factor of 4 decreased the leaked mass by only $11 \%$. Thus, for CSFT pool-fire conditions at least, precise knowledge of source particle size is not required to predict the concentration of particles suspended in the vessel atmosphere.

The predicted effect of a twelvefold change in source particle size on airborne mass concentration is shown in Figure 43. As indicated, the peak concentration is reduced by a factor of 2 for the larger particles but overal1 behavior is not drastically affected.

Masses of aerosol leaked from the vessel for these two cases are shown as functions of time in Figure 44. As expected, the higher airborne concentrations achieved for 1-um diameter particles leads to higher leaked masses. The difference is less than a factor of 2 , showing that even a large difference in source particle size (a factor of 12) has only a modest effect on leaked mass.

This brief evaluation of the effect of source particle size shows that for CSTF pool-fire conditions, predicted aerosol behavior is rather insensitive to assumed source particle size; therefore, the accuracy of predicted behavior is not heavily dependent on inputting the correct source size. This finding is in agreement with the work of Gieseke et a1: (2) who performed sensitivity analyses with the HAA-3 code for hypothetical containment buildings. 


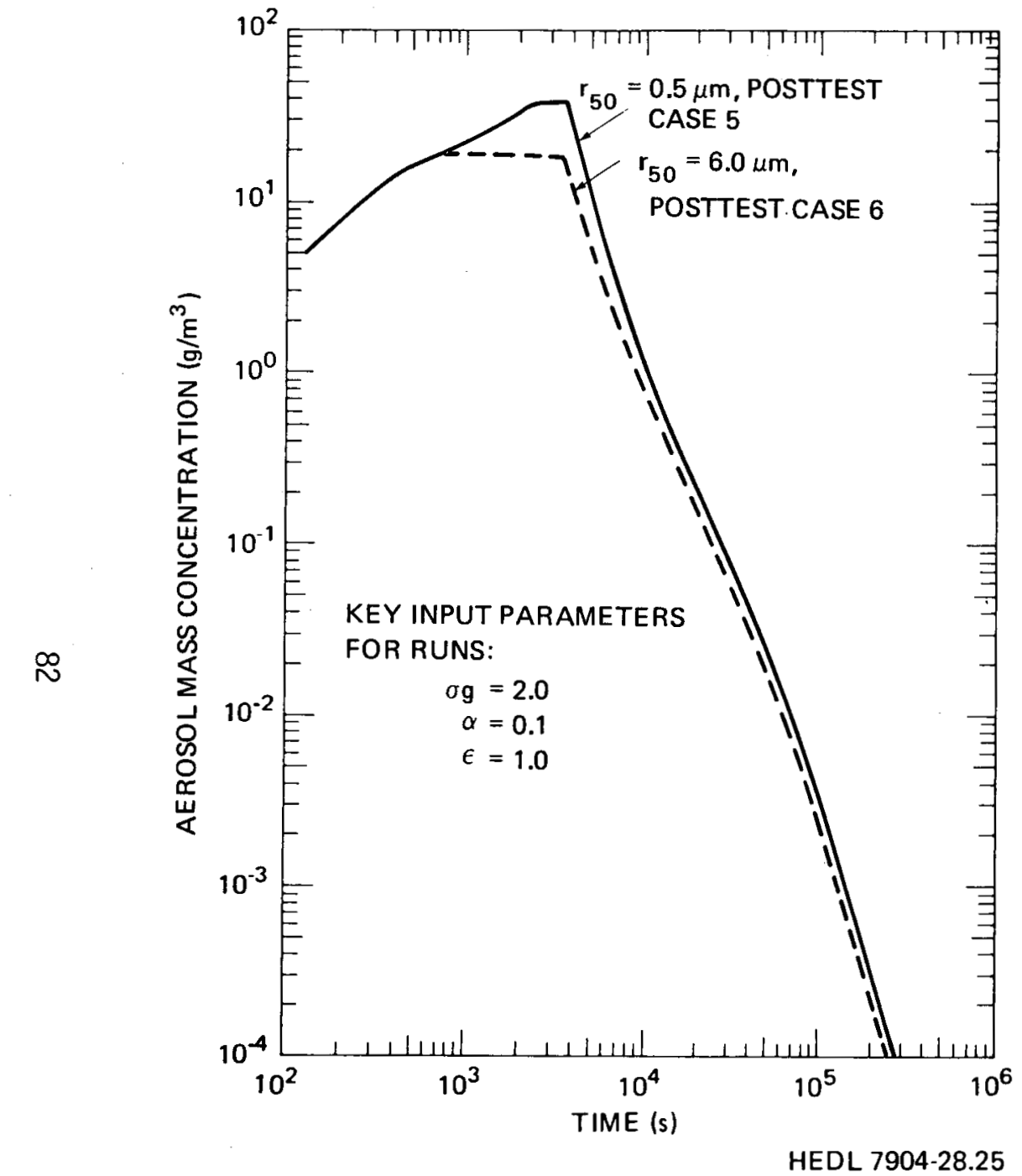

FIGURE 43. Predicted Aerosol Concentration for 1- and 12-um Diameter Particles.

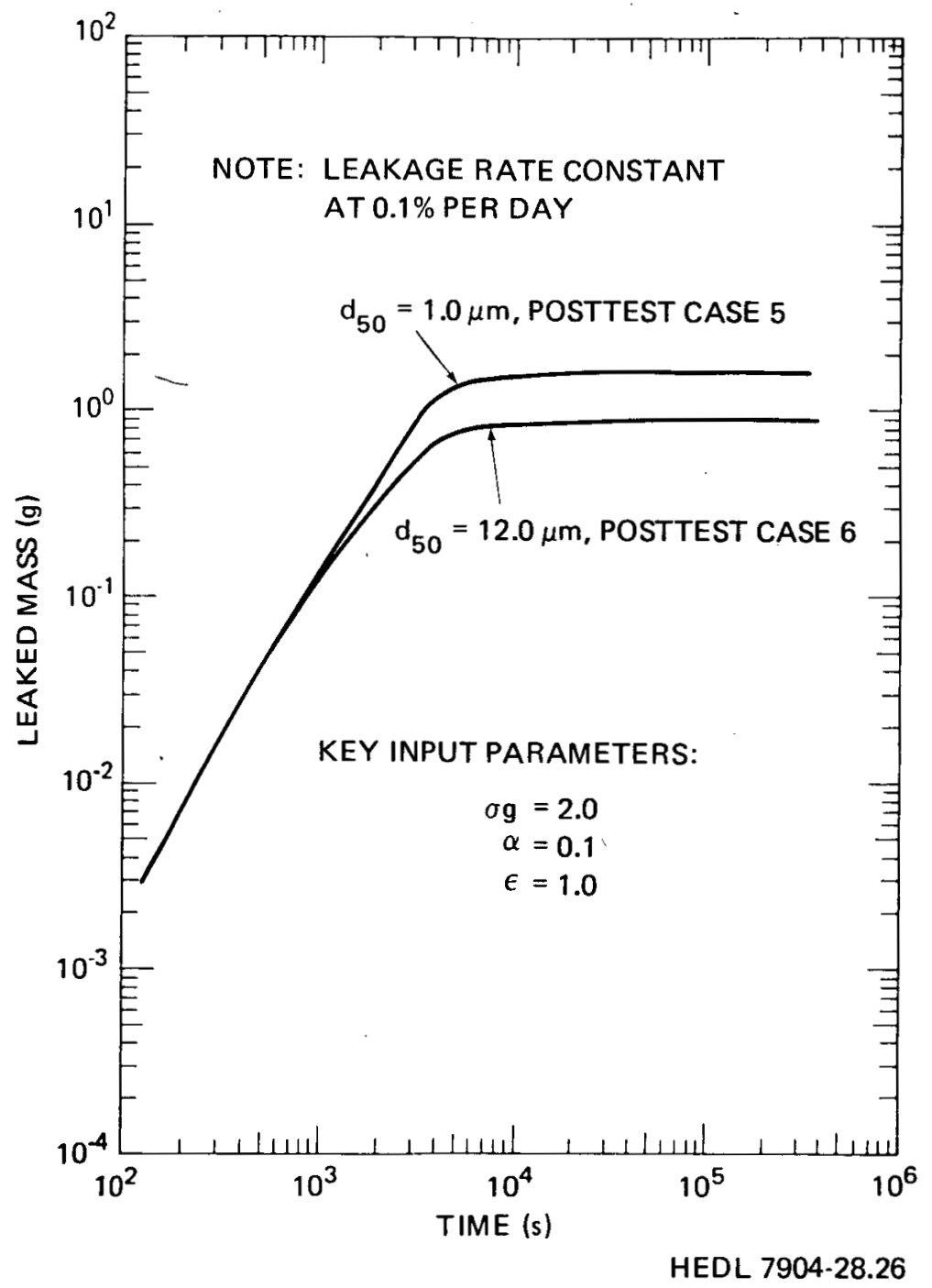

FIGURE 44. Predicted Effect of a Twelvefold Increase in Source Particle Size on Leaked Mass. 


\section{Density Modification Factor and Collision Efficiency}

Two important input parameters that affect the coagulation and fallout rate of aerosols in the HAA-3 code are density modification factor $(\alpha)$ and collision efficiency $(\varepsilon)$. The factor a originates from the modified form of Stokes' law for moving particles:

$$
F=\frac{6 \pi u r V}{\alpha}
$$

Where:

$F=$ Drag force on particle,

$\nu=$ Fluid viscosity,

$r=$ Particle radius,

$V=$ Relative velocity of particle, and

$\alpha=$ Correction factor that depends on particle shape (equal to unity for spheres).

The factor $\alpha$ is used as a multiplier of particle density $\rho_{m}$ in settling velocity calculations.

The gravity agglomeration efficiency, $\varepsilon$, is a multiplier of volume swept by falling particles in computing the gravity agglomeration rate. Thus, $\varepsilon$ is intended to correct for two effects: (22)

- The change in target area due to the nonspherical shapes of particles, and

- The change in collision rate attributed to bending of the particle trajectories by aerodynamic forces.

For a particle of aerodynamic diameter $d_{a}$, the product of cross-sectional area and settling velocity is proportional to $d_{a}^{4} / \rho$. Since the agglomeration rate is proportional to volume swept, the agglomeration rate for a particle with $\rho=\rho_{\mathrm{m}} \alpha$, divided by the agglomeration rate for a particle with $\alpha=1$ is 


$$
\frac{\text { Coagulation Rate }}{\text { Coagulation for } \alpha=1}=\alpha
$$

The result of this heuristic argument indicates that the coagulation rate, including $\varepsilon$ as a multiplier of swept volume, would be proportional to the $\alpha \varepsilon$ product. A number of parametric runs for pool-fire conditions in CSTF have verified that it is the $\alpha \varepsilon$ product, rather than individual values of $\alpha$ and $\varepsilon$, that affects the predicted aerosol behavior.

The effect of $\alpha \varepsilon$ product on predicted aerosol behavior for pool-fire conditions in CSTF was explored by making a number of computer runs in which $\alpha \varepsilon$ was a. parameter. Typical results are presented in Figure 45.

As indicated, smaller values of $\alpha \varepsilon$ lead to slower agglomeration and, therefore, higher aerosol concentrations. The experimental results appear to be explained by a values in the range of 0.5-0.1 during the burn period. After the source was terminated, smaller values of $\alpha \varepsilon$ appeared to be required to match the experiment.

Predicted leaked mass is shown as a function of $\alpha \varepsilon$ product in Figure 46 . For comparison, data calculated from AB2 measurements are also shown. The asymptotic value of mass leaked varied by a factor of 5 as $\alpha \varepsilon$ product varied by a factor of 25. Thus, the predicted leaked mass varies only as the square root of $\alpha \varepsilon$ product. The test results are consistent with an $\alpha \varepsilon$ product falling in the range of 0.5 to 0.1 .

In the computer runs made to explore ae product influence, source rate was taken as constant and water sorption was largely ignored; therefore, an optimum value of $\alpha \varepsilon$ cannot be defined from these particular computer runs.

\section{Effect of Water Vapor Uptake on Aerosol Concentration}

Sodium oxide particles generated by the burning of sodium wil1 react with available water vapor to form $\mathrm{NaOH} \bullet \times \mathrm{H}_{2} \mathrm{O}$. The extent of the reaction depends 


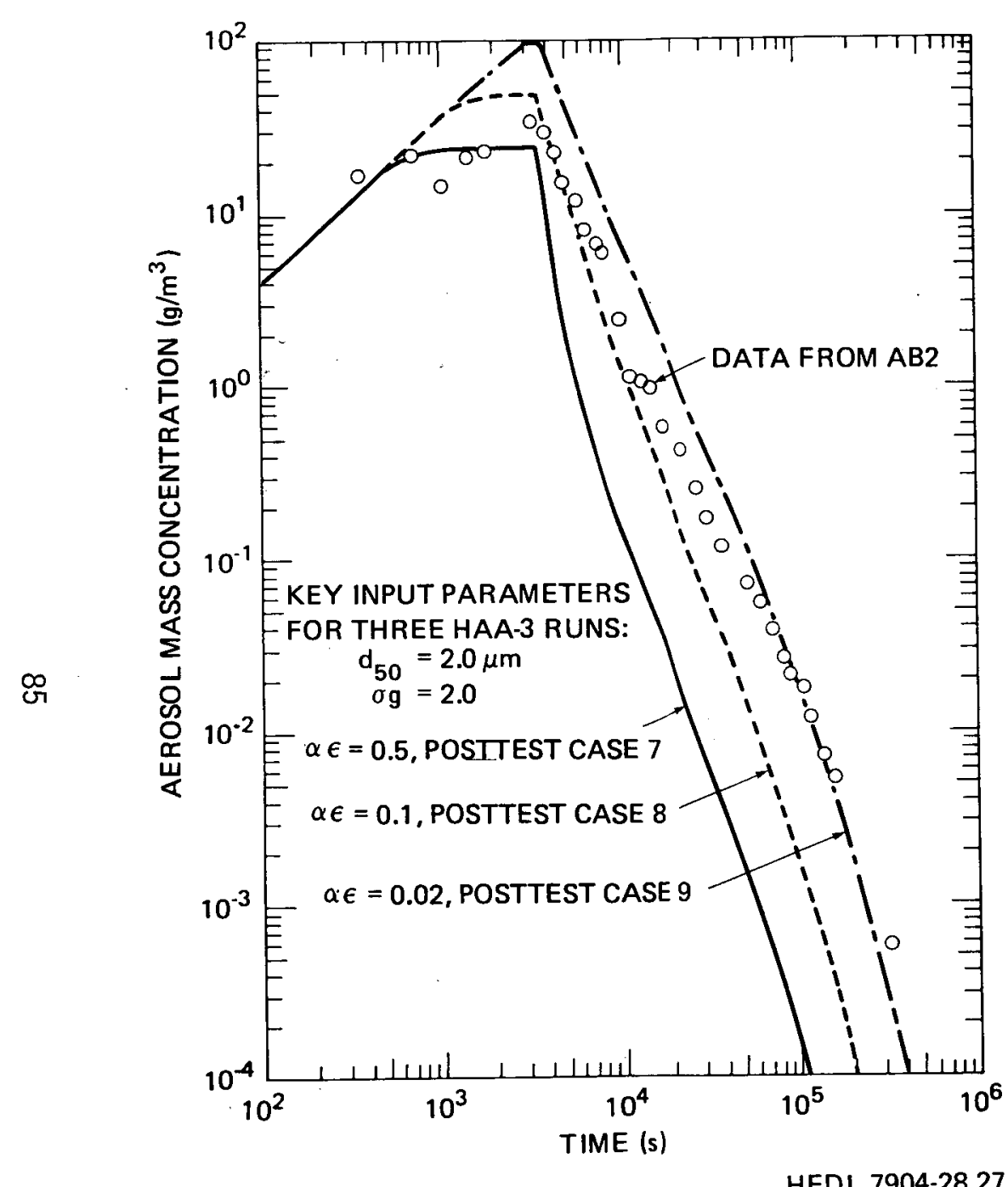

FIGURE 45. Effect of $\alpha \varepsilon$ Product on Predicted Aerosol Concentrations.

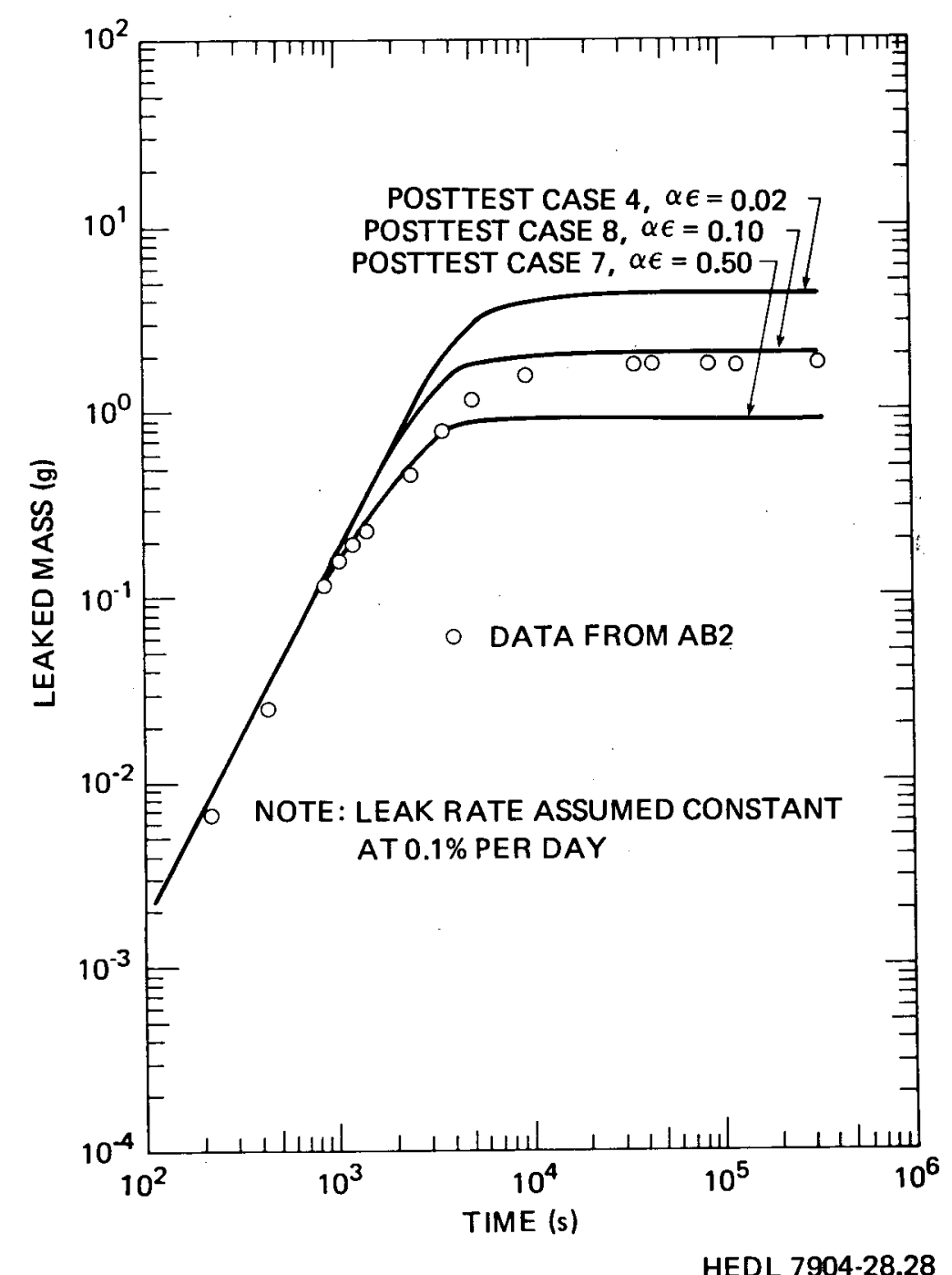

FIGURE 46. Effect of $\alpha \varepsilon$ Product on Predicted Leak Mass for Test AB2. 
on the relative amounts of the two materials present. The mass of individual particles would thus increase by a mechanism not accounted for in the HAA-3 code. The following potential effects of water vapor uptake are evident:

- Particle shape, size, and density could change if a dry particle sorbed enough water to convert it to a solution drop, and

- Suspended aerosol mass would increase or decrease, depending on the relative humidity.

Neither of these effects is directly accounted for in the HAA-3 code; however, water sorption, which increases aerosol mass, can be accounted for in terms of a pseudo aerosol generation rate.

To obtain the best fit between the HAA-3 code and CSTF experiments, a timedependent aerosol. source generation rate was computed. The following plausible assumptions were used to compute the source rate:

- The mass of sodium aerosolized was obtained from test results,

- Sodium aerosol production rate was assumed to be proportional to oxygen concentration,

- Aerosol particles were assumed to be in equilibrium with available water vapor, (25) and

- Water vapor uptake was counted as an aerosol source.

The source rates computed on the basis of these assumptions are summarized in Table 26.

For both tests, an initial peak in generation rate occurred because of sorption of water vapor initially present in the vessel. Aerosol production ceased in $A B T$ at one hour but continued until one hour 16 minutes in $A B 2$ due to steam addition. The sodium/total mass ratio based on the total aerosol added was computed to be 0.580 for $A B 1$ and 0.362 for $A B 2$. 
TABLE 26

TIME-DEPENDENT AEROSOL SOURCE RATE BASED ON

MEASURED AEROSOLIZATION AND WATER VAPOR AVAILABILITY

\begin{tabular}{|c|}
\hline $\begin{array}{c}\text { Time Interval } \\
(\mathrm{s})\end{array}$ \\
\hline $0-360$ \\
\hline $360-720$ \\
\hline $720-1080$ \\
\hline $1080-1440$ \\
\hline $1440-1800$ \\
\hline $1800-2160$ \\
\hline $2160-2520$ \\
\hline $2520-2880$ \\
\hline $2880-3240$ \\
\hline $3240-3600$ \\
\hline $3600-3960$ \\
\hline $3960-4320$ \\
\hline $4320-4560$ \\
\hline
\end{tabular}

\begin{tabular}{c}
$\begin{array}{c}\text { Source Rat } \\
(\mathrm{g} / \mathrm{s})\end{array}$ \\
\hline 37.69 \\
16.52 \\
16.08 \\
15.63 \\
17.50 \\
18.56 \\
18.00 \\
17.44 \\
16.88 \\
16.32 \\
0 \\
0 \\
0
\end{tabular}

AVERAGE
Test $A B 1$

Sodium/Total

Mass Ratio

0.334

0.742

0.742

0.742

0.644

0.590

0.590

0.590

0.590

0.590

0.580

\begin{tabular}{ccc}
$\begin{array}{c}\text { Tource Rate } \\
(\mathrm{g} / \mathrm{s})\end{array}$ & $\begin{array}{c}\text { Sodium/Total } \\
\text { Mass Ratio }\end{array}$ \\
\cline { 1 - 1 } 35.30 & & 0.336 \\
15.65 & & 0.461 \\
21.66 & & 0.480 \\
34.04 & & 0.431 \\
31.84 & & 0.411 \\
29.50 & & 0.402 \\
29.91 & & 0.394 \\
30.36 & & 0.386 \\
28.75 & & 0.381 \\
28.14 & & 0.378 \\
7.79 & 0.368 \\
1.55 & 0.366 \\
4.82 & 0.362 \\
& 0.362
\end{tabular}

To achieve consistency between predictions and experimental measurements, the same sodium/total mass ratio must be employed in the source rate and in converting sodium mass to total aerosol mass in obtaining experimental values of total aerosol mass.

Comparisons between experiment and theory for $A B 1$ are made in Figure 47 . $A$ very good fit is obtained when $\alpha \varepsilon$ is assigned a value of 0.20 . Predictions based on an $\alpha \varepsilon$ product of 0.10 fall above the experimental data.

Predicted and measured airborne mass concentrations for Test $A B 2$ are compared in Figure 48. The prediction based on an $\alpha \varepsilon$ product of 0.20 agrees best with the measured concentrations near the maximum. When $\alpha \varepsilon$ is assigned a value of 0.10 , the maximum concentration is overpredicted. 


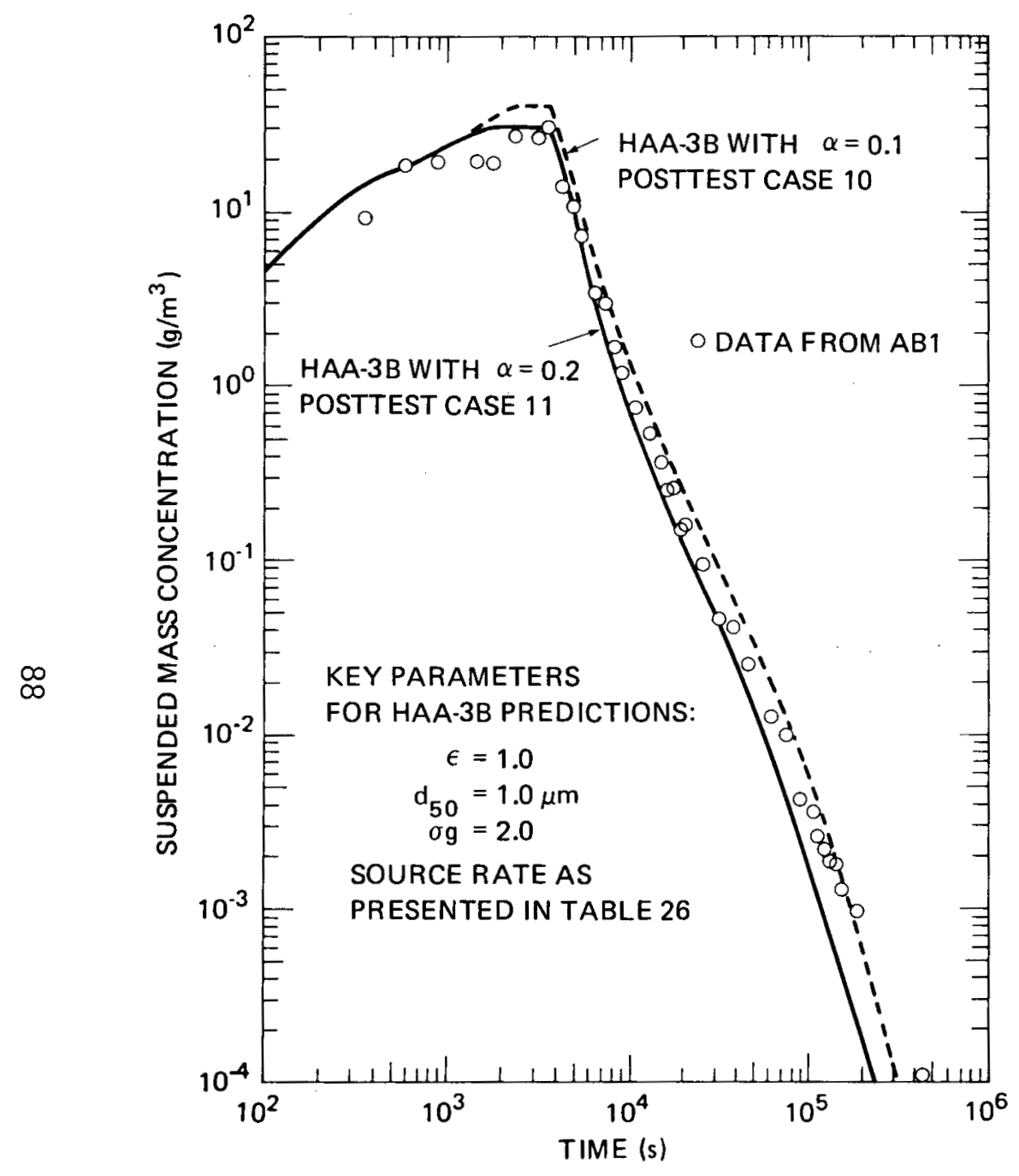

HEDL 7904-28.29

FIGURE 47. Comparison of Measured and Predicted Aerosol Concentrations for Test ABI.

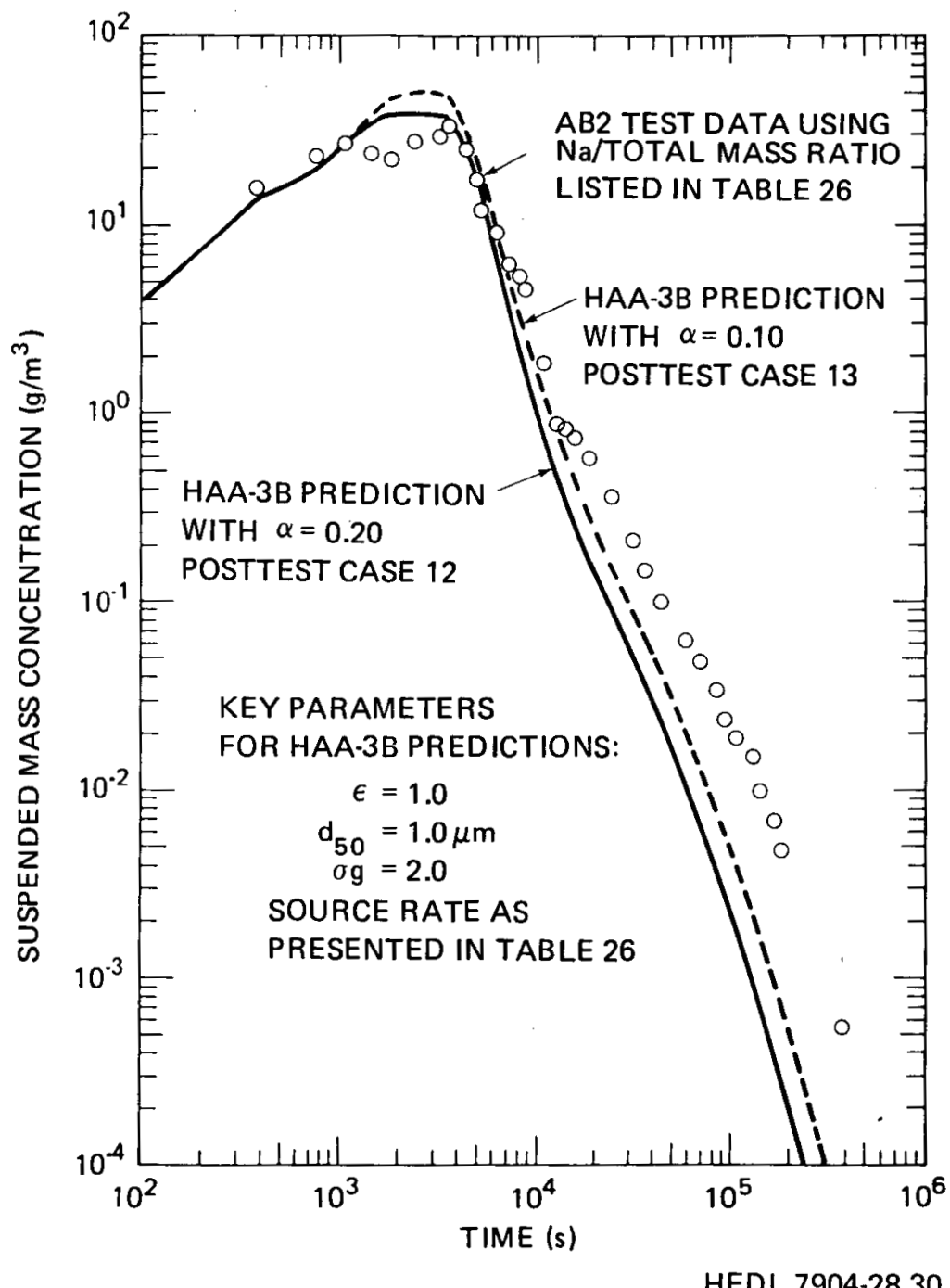

FIGURE 48. Comparison of Measured and Predicted Airborne Concentrations in Test AB2. 
For Test AB2, both predictive curves fell slightly below the measured concentrations during the longer-term aerosol depletion phase. This minor discrepancy was not evident in Test $A B 1$ and, therefore, appears to result from steam addition. The cause for the slightly slower fallout in $A B 2$ has not been identified, but as shown in the following leakage calculations, the minor discrepancy does not significantly affect the aerosol mass leaked.

Calculated values of mass leaked are presented in Figure 49 for Test $A B 1$. Predictions based on an $\alpha \varepsilon$ product of 0.2 and the time-dependent source rate listed in Table 26 (page 87) are in near-perfect agreement with test results. When ar is assigned a value of 0.1 , test results are overpredicted for times longer than 3000 seconds.

Leaked masses for Test $A B 2$ are shown in Figure 50. As was the case for Test $A B 1$, predictions agree with experiment when $\alpha \varepsilon$ is assigned a value of 0.20 and the source rate is computed to account for water vapor sorption. The goodness of fit between predictions and experiment is better for leaked mass (Figure 50) than for the suspended concentrations (Figure 48) because the deviations evident in Figure 48 occur at low mass concentrations and, therefore, contribute little to leaked mass.

The very good agreement achieved between experiment and theory when the aerosol source rate is formulated to account for water vapor sorption demonstrates that the HAA-3B code is fully adequate in predicting aerosol behavior under CSTF pool-fire conditions, provided the aerosol source rate is known.

Posttest predictions were made with the HAARM-3 code by workers at Battelle, Columbus Laboratory. Pretest input parameters were modified to match the mass of aerosol created by the sodium fire. Also, the settling area was increased to account for the horizontal projection of structures and equipment inside the vesse1. 


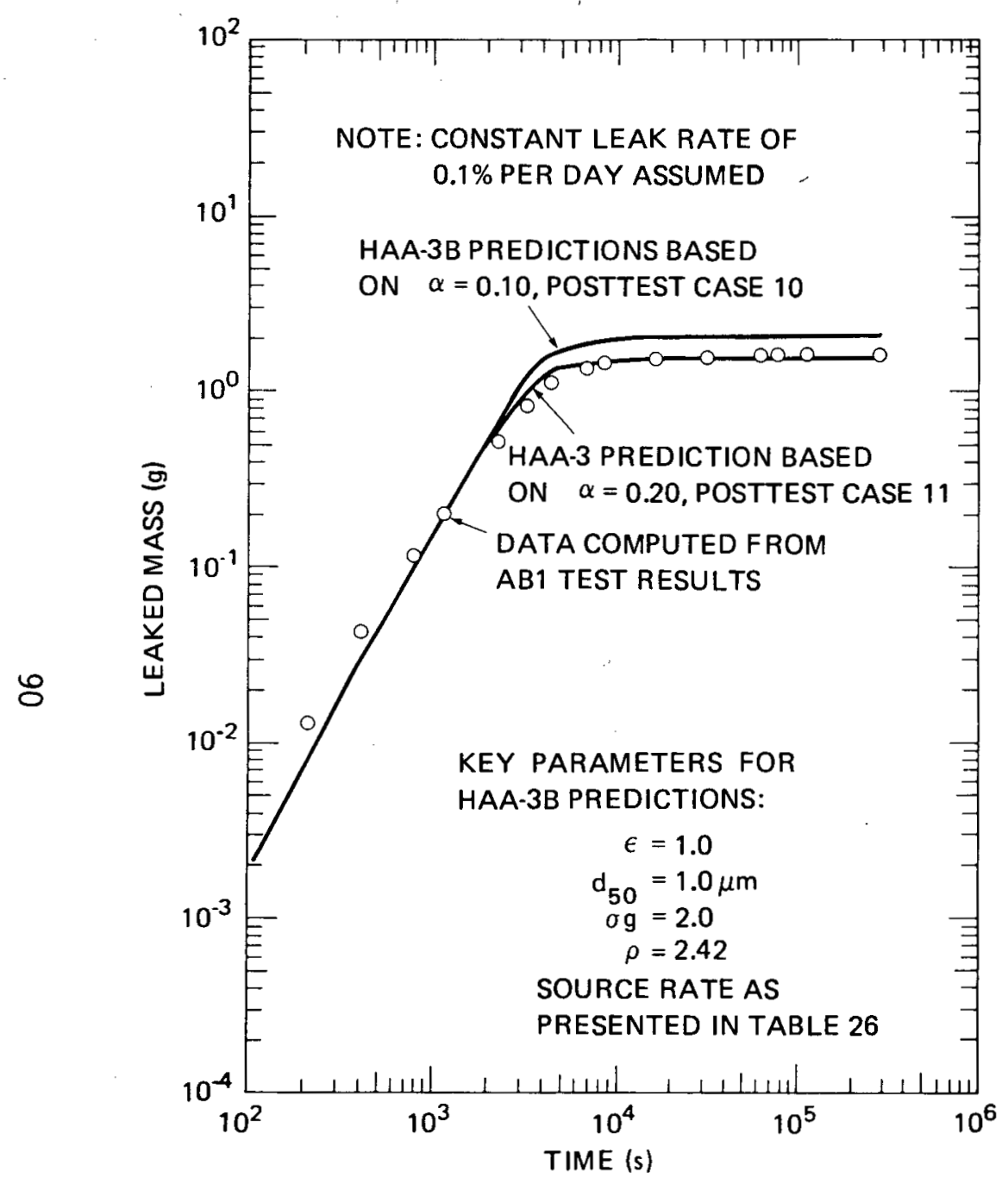

HEDL 7904-28.31

FIGURE 49. Comparison of Predicted and Measured Aerosol Mass Leaked for Test ABI When Water Vapor Uptake is Accounted for.

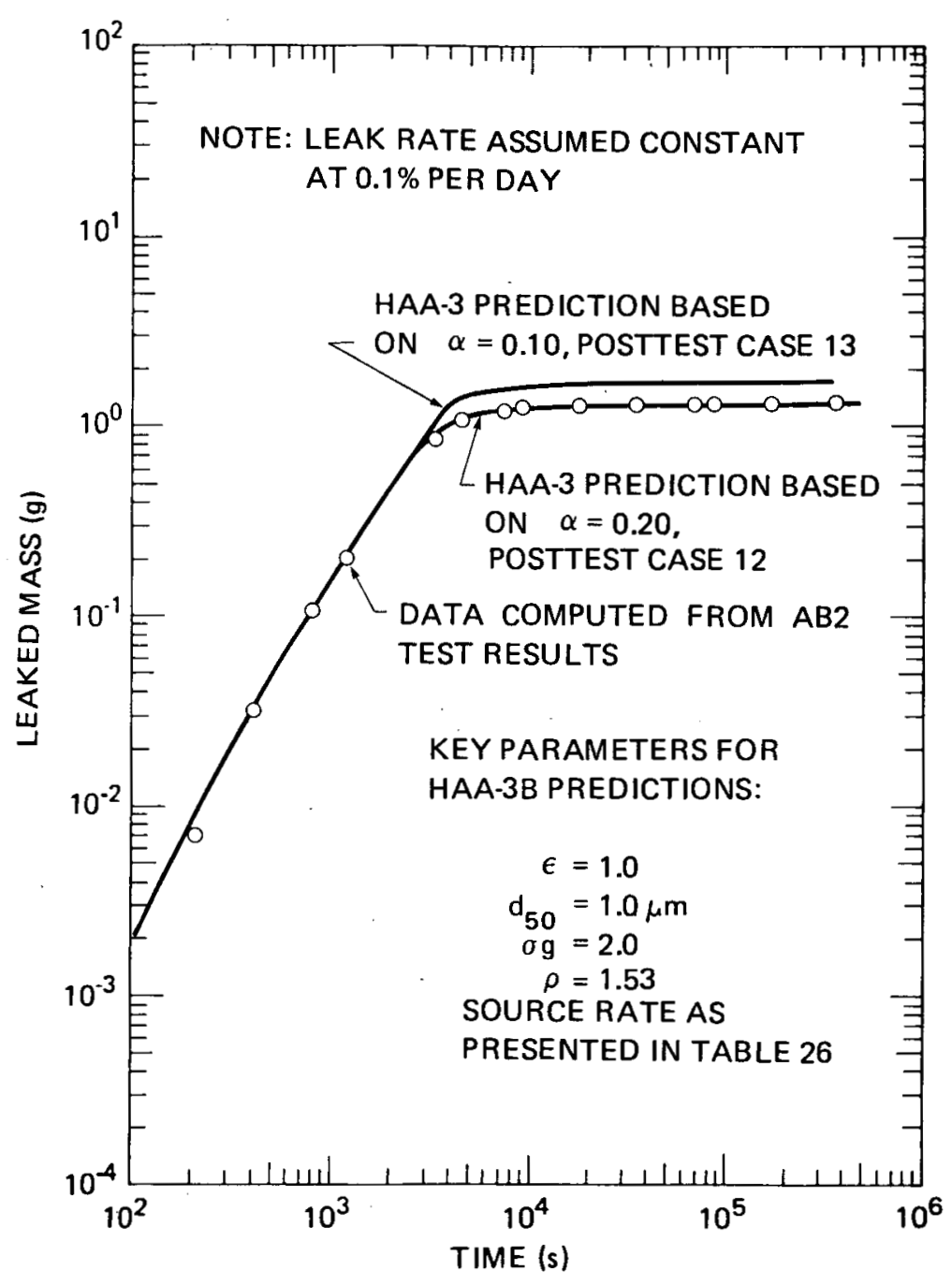

HEDL 7904-28.32

FIGURE 50. Comparison of Predicted and Measured Aerosol Mass Leaked for Test AB2 When Water Vapor Uptake is Accounted for. 
Posttest predictions of airborne mass concentration made by HAARM-3 for Test $A B 1$ are compared to experimental data in Figure 51. Note that the experimentally derived mass concentration was based on the sodium/total mass ratios listed in Table 26 (page 87).

The goodness of fit is similar to that obtained in the pretest prediction (shown in Figure 37, page 72). The code overpredicted the maximum concentration obtained at the end of the burn (at $3600 \mathrm{~s}$ ) by a factor of 2; however, for earlier and later times the fit between the code and test results is very good.

The fit between posttest HAARM- 3 predictions and Test $A B 1$ results when compared on a mass leakage potential basis is shown in Figure 52 . The model overpredicts the asymptotic value of mass leaked by a factor of 1.5 . The HAARM-3 prediction for Test $A B 1$ agrees well with the HAA-3B prediction, which used an $\alpha \varepsilon$ product of 0.10 . As shown on Figure 49 (page 90), the HAA-3B prediction based on an $\alpha \varepsilon$ product of 0.20 was in near-perfect agreement with the leaked mass data of Test $A B 1$.

A posttest prediction for Test AB2 based on HAARM-3 is compared to experimenta] data in Figure 53. This prediction is improved compared to the pretest prediction by HAARM-3 exhibited in Figure 37 (page 72). Water vapor, added as steam in Test AB2, was accounted for in the aerosol source term used in the posttest prediction, and the corrected source term improved the fit with the experiment.

The HAARM-3 code overpredicted the maximum concentration reached at $3600 \mathrm{~s}$. For times longer than $2 \times 10^{4}$ seconds, the prediction falls slightly below the data.

HAARM-3 predictions of leaked mass are shown in Figure 54 . The asymptotic leaked mass predicted by the code is 1.5 times higher than the measured value. Interestingly, this is the same degree of conservatism that was obtained for Test $A B 1$. 


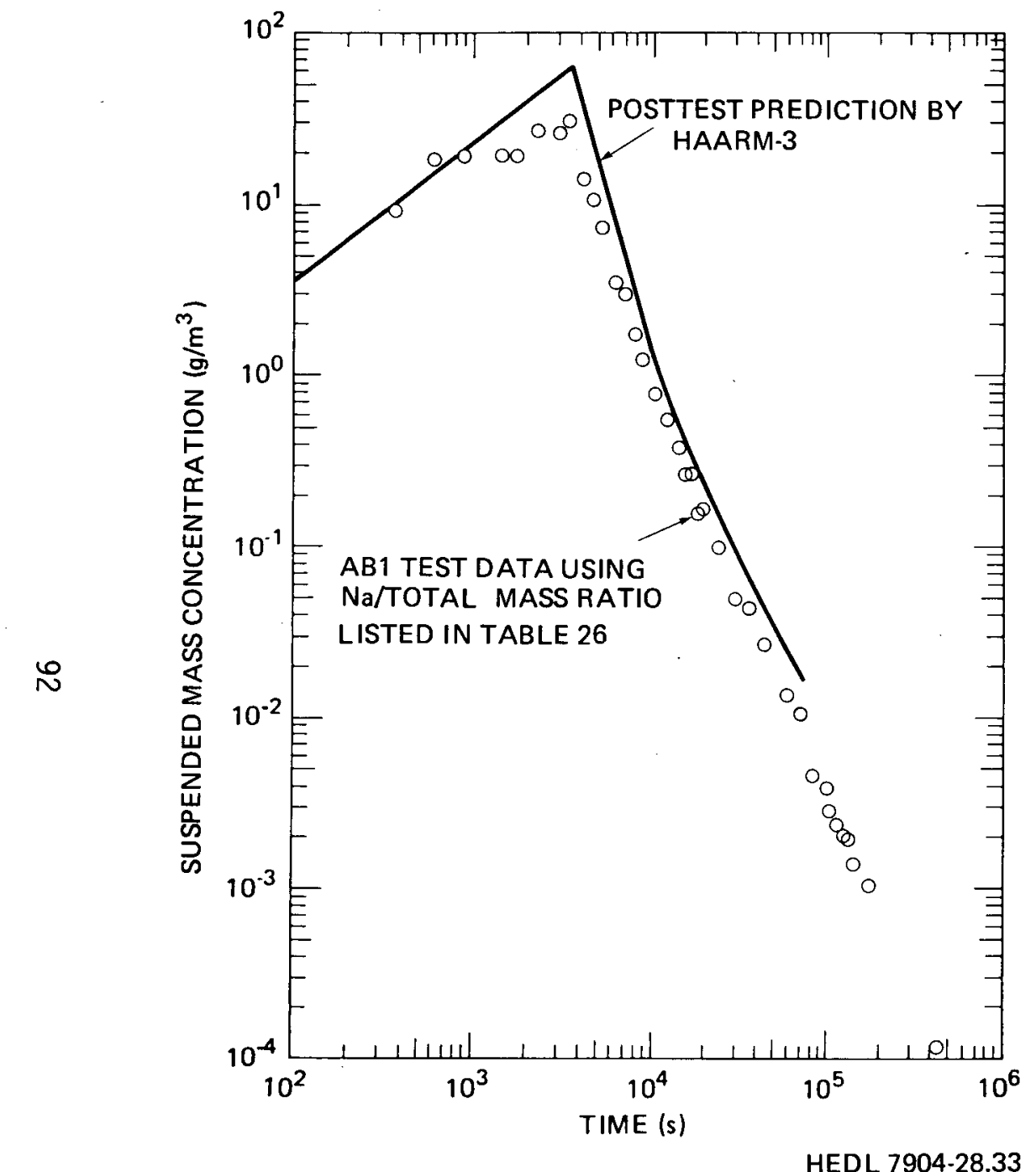

FIGURE 51. Posttest Fit of HAARM-3 With Test $A B 1$.

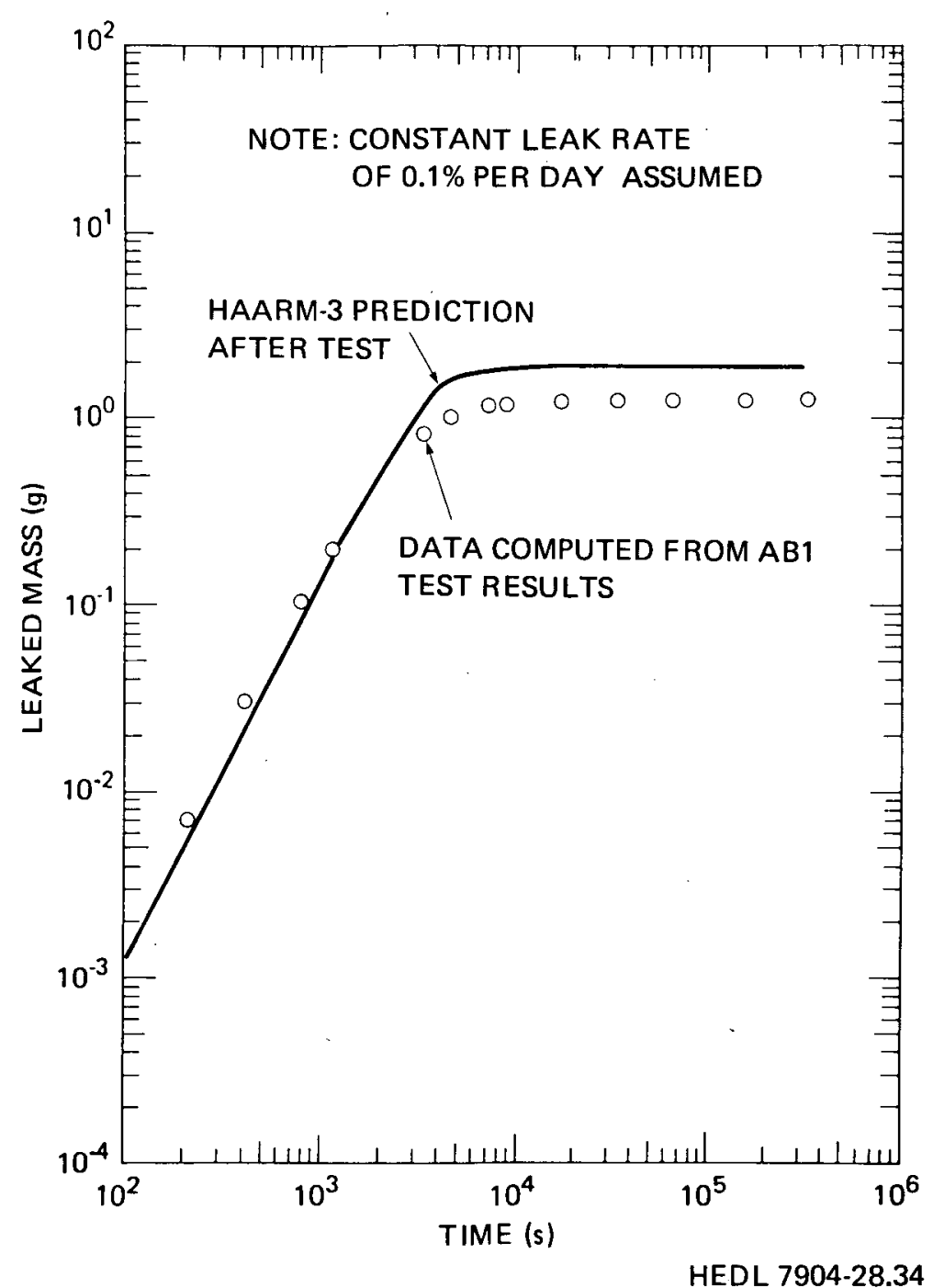

FIGURE 52. Posttest Prediction of Leaked Mass by HAARM-3 for Test AB1. 

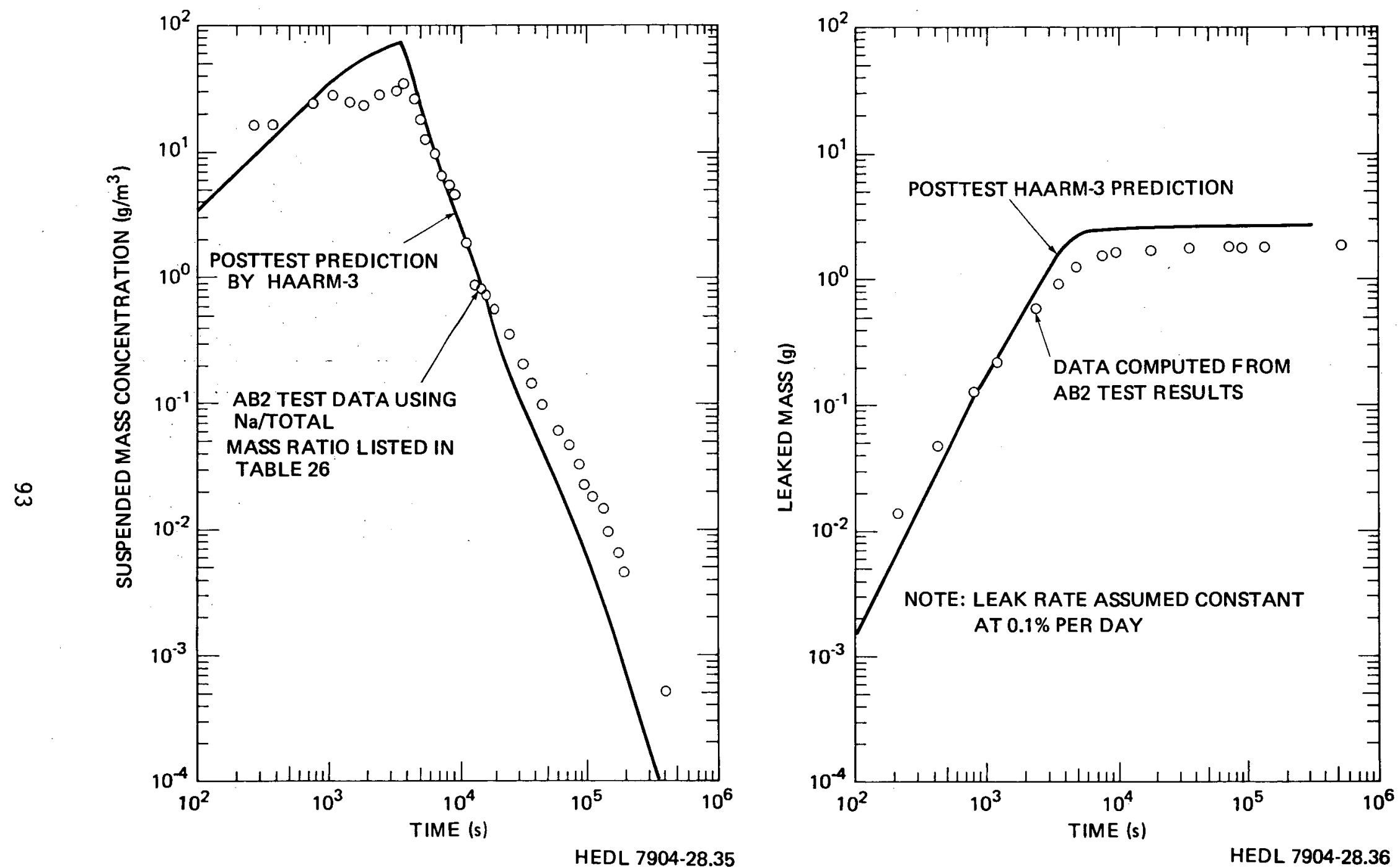

FIGURE 53. Posttest Fit of HAARM- 3 With Test AB2.

FIGURE 54. Posttest Prediction of Leaked Mass by HAARM-3 for Test AB2. 
While the HAARM- 3 fit of leaked mass for Test $A B 2$ is less accurate than the $H A A-3 B$ prediction made with an $\alpha \varepsilon$ product of 0.20 , it is considered to be very good.

This brief comparison of the two aerosol codes with the CSTF pool-fire tests has led to the following conclusions:

- $\quad H A A-3 B$ and HAARM-3 predictions are quite similar.

- The HAA-3B code predictions agreed very well with results from the two experiments when an $\alpha \varepsilon$ product of 0.20 was employed.

- HAARM-3 appears to overpredict the peak in aerosol concentration attained at the end of a 3600-s sodium fire. This overprediction of concentration leads to an overprediction in leaked mass by a factor of 1.5. Overal1, HAARM-3 predictions are in good agreement with test results.

- $\quad$ Pretest and posttest predictions of aerosol behavior differed by small factors (<2). The main change in code inputs were made to obtain a mass source rate that was consistent with the mass of aerosol determined from the experiments.

\section{COMPARISONS BETWEEN PREDICTED AND MEASURED PARAMETERS}

Predictions based on optimum HAA-3B runs are compared with experimental measurements in this section.

\section{Particle Size}

Predicted and measured particle sizes for Test $A B 1$ are compared in Figure 55. The particle diameter shown, aerodynamic mass median diameter, was computed from $H A A-3 B$ output using equation (7).

$$
\text { AMMD }=2 R_{50}(\rho \alpha)^{0.5}
$$




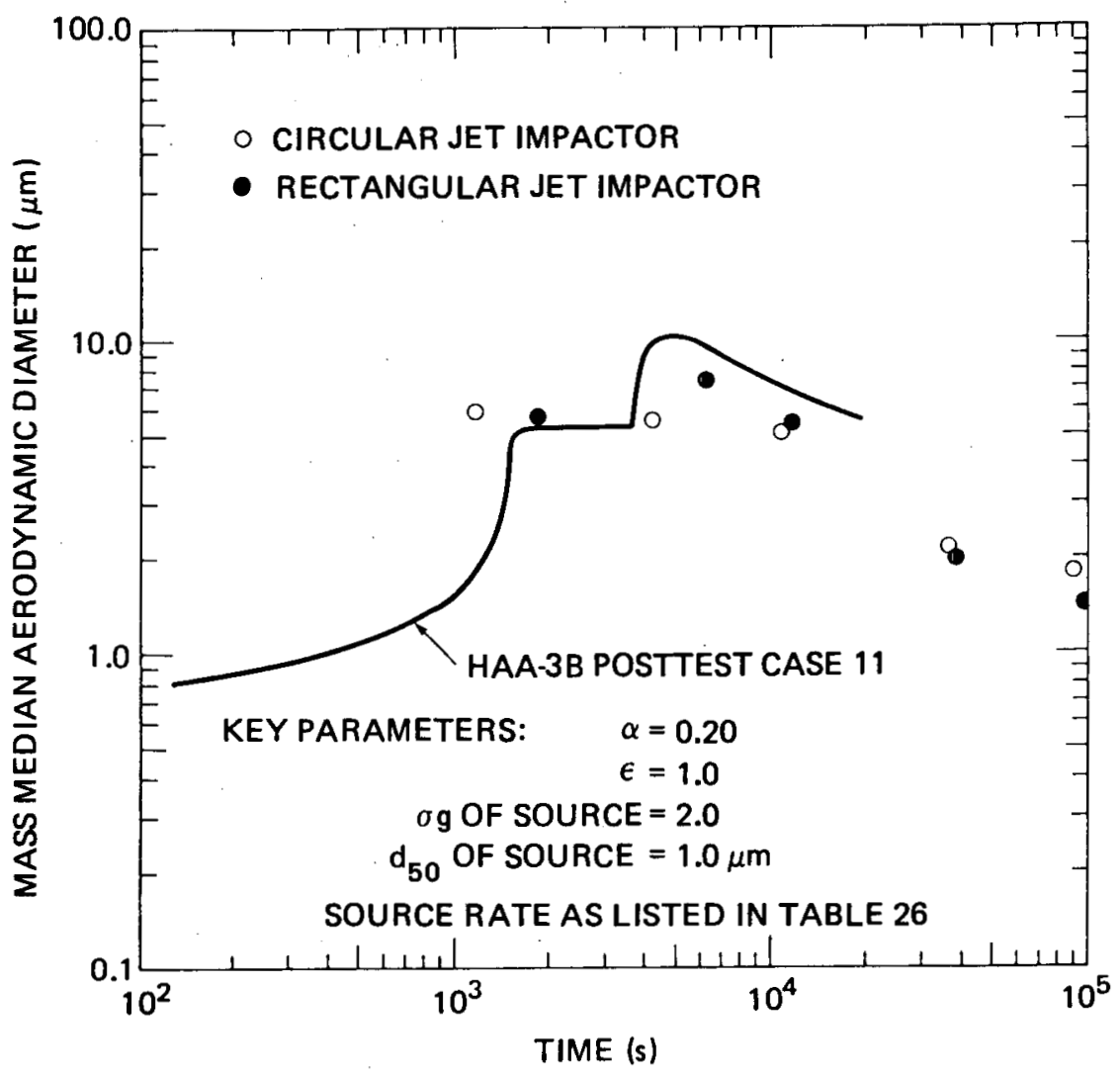

HEDL 7904-28.37

FIGURE 55. Measured and Predicted Particle Size in Test AB1.

Where:

$$
\begin{aligned}
\text { AMMD } & =\text { Aerodynamic mass median diameter } \\
\mathrm{R}_{50} & =\text { Mass median particle radius, } \\
\rho & =\text { Aerosol material density, and } \\
\alpha & =\text { Density modification factor. }
\end{aligned}
$$

For $A B 1,(\rho \alpha)^{0.5}$ had a value of $[(2.42)(0.2)]^{0.5}=0.696$.

As shown by the results in Figure 55, the cascade impactor measurements agreed well with the HAA-3 predictions except for the earliest sample, which was taken at 11,40 seconds. The measured mean particle diameter, $6 \mu \mathrm{m}$, was appreciably larger than the 2-um diameter predicted by the code. Agglomeration occurring in the burning zone and in the plume above the burn pan may well account for the larger measured particle size. 
The effective settling diameter, which characterizes the mass settling rate, is related to the mass median particle diameter by equation (1).

$$
\left(d_{s}\right)_{a}=\text { AMMD exp }\left(1 n^{2} \sigma_{g}\right)
$$

Where:

$\left(d_{s}\right)_{a}=$ Aerodynamic settling mean diameter,

AMMD = Aerodynamic mass median diameter, and

$\sigma_{g}=$ Geometric standard deviation.

Settling mean diameters computed from cascade impactor data and settling measurements are compared with HAA-3B code predictions for Test $A B T$ in Figure 56. Very good agreement is apparent except for the earliest sample. Again, agglomeration in the sodium burning zone and in the plume apparently caused significant particle growth.

A settling mean particle diameter was computed from the concentration decay curve measured after the aerosol source was terminated. The variation in settling mean diameter calculated in this way is shown on Figure 56 as a dashed line. Very good agreement with the line calculated from the HAA-3B code is apparent.

Measured and predicted mass median particle diameters for Test AB2 are compared in Figure 57. Very good agreement was found except for the sample withdrawn at 1060 seconds. Whereas the HAA-3B code indicated that little particle growth would be achieved at 1060 seconds, the cascade impactor sample showed that airborne particles were $4.8 \mu \mathrm{m}$ AMMD.

In addition to cascade impactors, a gravity settling sampler was used to measure particle size. The sampler consisted of an array of horizontal channels, and the particle size distribution was computed from lengthiwise analyses of the particle deposit. This sampler was constructed to provide a size spectrometer that would not subject the particles to high shear stresses and, 

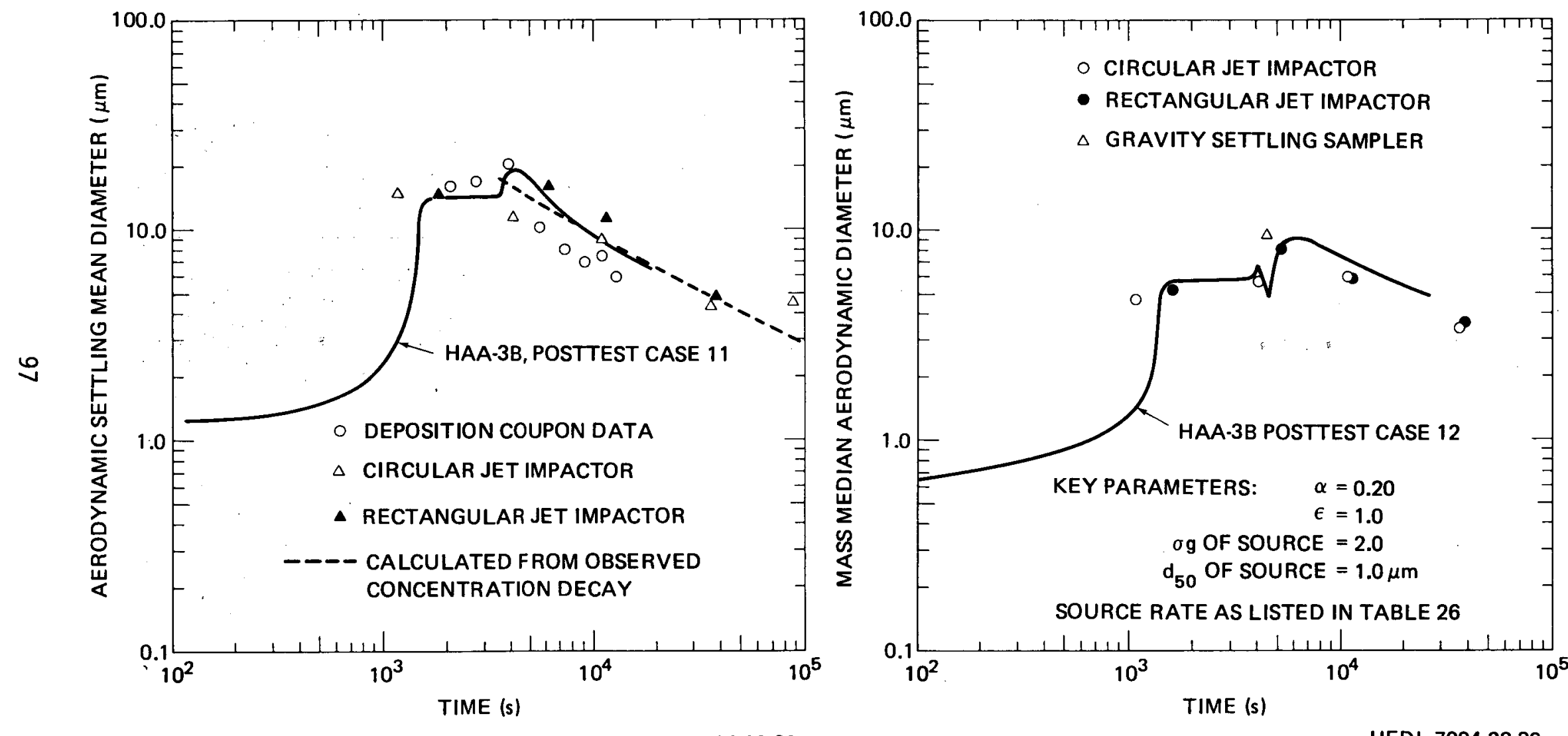

FIGURE 56. Comparison of Measured and Predicted Settling Mean Particle Diameters in Test $A B 1$.

FIGURE 57. Comparison of Measured and Predicted Mean Particle Diameters in Test AB2. 
therefore, would not raise questions about the breakup of fragile agglomerates. As indicated, the size measured by the gravity sampler is in good agreement with the impactor results, suggesting that particle breakup was not important.

Aerodynamic settling diameters that were computed from $A B 2$ test results are shown in Figure 58. Particle diameters computed from cascade impactor data agree quite well with HAA-3B predictions except for the early sample. The circular jet impactor sample withdrawn at 1080 seconds indicated a particle diameter of $27.6 \mu \mathrm{m}$. The large diameter calculated from the first impactor sample reflected an unusually large standard deviation (3.8) obtained from a graphic plot of stage mass accumulations. This large standard deviation was singularly high and may be erroneous. On the other hand, the deposition coupon data agreed quite well with the cascade impactor for this early sample.

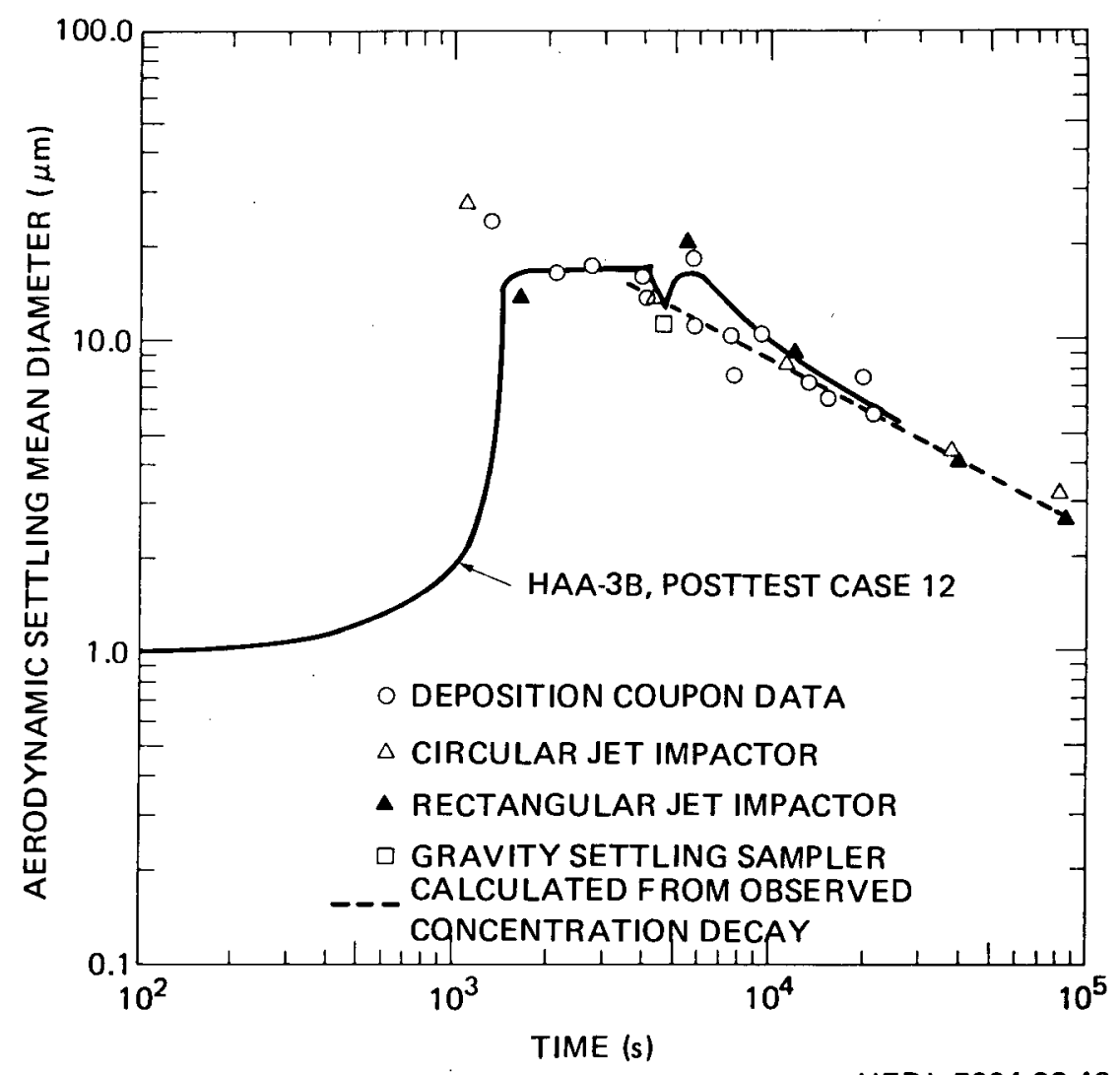

FIGURE 58. Comparison of Measured and Predicted Settling Mean Particle Diameters in Test AB2. 
The settling mean diameter computed from the gravity settling sampler result agreed well with the HAA-3B prediction. Likewise, the settling mean diameter computed from deposition coupons and the concentration decay curve (shown as a dashed line on Figure 58) agreed well with the HAA-3B predictions.

In summary, the particle size distributions predicted by the $H A A-3 B$ code were in good agreement with the experimental measurements made in both Test $A B 1$ and Test $A B 2$.

\section{Plated Mass}

Wall deposition of particles is computed in $H A A-3 B$ as though the plateout rate were controlled by diffusion across a boundary layer of thickness $\triangle$ :

$$
\text { Plateout Rate }=\frac{\left(C_{g}-C_{w}\right) D A_{w}}{\Delta}
$$

Where:

$c_{g}=$ Particle concentration in bulk gas,

$C_{w}=$ Particle concentration in gas at surface, assumed to be zero,

$D=$ Particle diffusivity,

$A_{W}=$ Wall area for plateout, and

$\Delta=$ Thickness of boundary layer.

In the $H A A-3 B$ runs made for Tests $A B 1$ and $A B 2$, the boundary layer thickness was assigned a value of $1 \times 10^{-5} \mathrm{~cm}$ and the wall area, accounting for internal structures, was assigned a value of $1000 \mathrm{~m}^{2}$. This area is 1.92 times the area of the outer vessel wall $\left(520 \mathrm{~m}^{2}\right)$. Because the plateout rate is proportional to the $A_{W} / \Delta$ ratio, one would have to use a $\Delta$ of $10^{-5} / 1.92=0.52 \times 10^{-5} \mathrm{~cm}$ if the wall area were taken as the outer vessel wall alone and one wanted to obtain a similar plateout fraction. 
Plateout fractions measured in Tests $A B 1$ and $A B 2$ are compared to $H A A-3 B$ predictions in Table 27. The measured plateout fractions are smaller but of the same order of magnitude as the predicted fractions. Better agreement could have been obtained by adjusting the value of $\Delta$ to $1.6 \times 10^{-5} \mathrm{~cm}$, but this was not done.

TABLE 27

COMPARISON OF MEASURED AND PREDICTED PLATEOUT

IN CSTF POOL-FIRE TESTS

\begin{tabular}{ccc} 
Test Number & \multicolumn{2}{c}{ Fraction of Aerosol Mass Plated } \\
\cline { 2 - 2 } & $\frac{\text { Predicted }(a)}{A B 2}$ & Measured \\
AB2 & 0.15 & 0.084 \\
0.10 & 0.069
\end{tabular}

(a) Using $A_{W} / V=1.176(-2) \mathrm{cm}^{-1}, \Delta=1.0(-5) \mathrm{cm}$.

Visual observations of the wall deposit suggested that most deposition occurred by a process other than diffusion. Vertical walls were covered with a very thin layer of fine oxide particles plus larger spotty deposits of oxide several millimeters in diameter, which protruded outward by as much as several millimeters and were spaced about $10 \mathrm{~mm}$ apart. Some larger spots, 10 to $20 \mathrm{~mm}$ in diameter, protruding as much as $6 \mathrm{~mm}$ from the wall, were also present. The density of the wall deposit was strongly affected by outward projections and wall roughness. These observations suggested that wall deposits formed mainly by two processes: 1) smal1 roughness projections captured moving particles by impaction, and 2) particles were deposited by turbulent deposition when the boundary layer was disturbed by a surface irregularity.

In summary, wall plateout was predicted within a factor of 2 using a $\Delta$ of $10^{-5}$ $\mathrm{cm}$; however, the visual appearance of the wall deposit suggested that interception and turbulent deposition were the dominant transport processes. 
Because wall plateout is a minor factor in aerosol removal, inaccuracies in predictions of wall plateout have little impact on calculations of leaked mass and settling.

\section{CONCLUSIONS REGARDING HAA-3B MODEL PREDICTIONS}

The comparisons between the large-scale pool-fire aerosol tests and HAA-3B predictions have shown the code to be a good predictor of the most important aspects of aerosol behavior. Although similar conclusions probably apply to the HAARM-3 code, the few cases run with this code do not warrant final conclusions. The following conclusions and summary statements apply to the HAA-3B code.

- Airborne mass concentration and leaked mass were accurately predicted by the code when the correct aerosol source was employed.

- Optimum agreement between theory and experiment was obtained when the $\alpha \varepsilon$ product was assigned a value of 0.20 . This value is close to values obtained from smaller-scale experiments at Atomics International ${ }^{(22)}$ and from single-particle measurements made at Battelle, Columbus Laboratory. (26)

- Predicted values of airborne mass concentration and leaked mass were quite insensitive to input parameters such as source particle size distribution and floor area.

- For times longer than $\sim 1000 \mathrm{~s}$, the predicted and measured particle size distribution agreed very well; at shorter times, the code underpredicted particle size. This discrepancy is thought to have resulted from agglomeration of particles in the burning zone and in the plume above the pool, which is not fully accounted for by the model.

- Plated mass would agree with the predicted value if a $\Delta$ of $01.6 \times 10^{-5} \mathrm{~cm}$ were used. This boundary layer thickness appears to be unrealistically small. Visual observations 
of the spotty wall deposit suggested that mechanisms other than diffusion-controlled wall deposition; however, wall deposition is a minor removal mechanism in large containment vessels, so imprecise predictions of this quantity have little impact on controlling aspects of aerosol behavior for full-scale reactor plants. 


\section{EFFECT OF WATER VAPOR ON AEROSOL BEHAVIOR}

As discussed earlier in this report, water vapor in appreciable concentration may be released along with sodium aerosols under accident conditions. Because of its likely presence, it is important to know how water vapor uptake influences aerosol behavior. Test AB2 was designed to uncover any major effects of water vapor on aerosol behavior.

The following phenomena are possible as a result of water vapor sorption:

- Conversion of oxide aerosol to hydroxide,

- Fluctuation of particle mass, depending on the relative humidity in the atmosphere,

- Conversion of solid aerosol particles to liquid particles in cases of high relative humidity, and

- Formation of gas bubbles within the agglomerate particles as a result of the reaction of water with sodium peroxide and the release of oxygen for cases of intermediate relative humidity.

The main questions that are raised by these phenomena are:

- Do spherical solution drops behave differently than nonspherical solid particles?

- How does the mass uptake of water affect aerosol behavior?

The increase in aerosol mass caused by water vapor sorption was modeled by considering the total aerosol mass generation to be the sum of the oxide production rate plus the water vapor sorption rate. While this approach is not rigorous when viewed on a microscopic scale, it was shown to be valid for Test AB2. The good agreement between predicted and measured aerosol behavior and particle properties evident in Figures $48,50,57$, and 58 (pages 88, 90, 97, and 98) show that the modeling approach is satisfactory. 
Some differences in aerosol fallout between the wet and dry tests were observed--as is evident from the two data sets presented in Figure 36 (page 72). These differences can also be seen by comparing the fits between code and experiment for the two tests (see Figures 47 and 48, page 88). Whereas in Test $A B 1$ the predicted curve based on $\alpha \varepsilon=0.1$ was conservative for the entire fallout period, data obtained in the wet test fell above the predicted line for concentrations below $10 \mathrm{~g} / \mathrm{m}^{3}$.

Al though it was not possible to pinpoint the cause for this discrepancy, it can be stated that its effect was minor. Slower fallout after the source was terminated was offset by a more rapid fallout during the fire. Leaked mass for the wet test agreed very well with predictions (as shown in Figure 50, page 90 ).

The conclusion was that water vapor uptake could be adequately handled by the HAA-3B code by including it in the source rate. No other significant effects of water vapor sorption were evident. 


\section{REFERENCES}

1. M. A. Greenfield, R. L. Koontz, and D. F. Hausknecht, "Characterization of Aerosols Produced by Sodium Fires, Vol II, Comparisons of Experiments With a General Equation for the Coagulation of Heterogeneous Aerosols," AI-AEC-12878, Atomics International, October 1969.

2. J. A. Gieseke et al. "Analytic Studies of Aerosol Behavior Predictions for Fast Reactor Studies," BMI-1932, Battelle, Columbus Laboratories, March 18, 1975.

3. F. L. Horn and A. W. Castleman, Jr., "PuO $\mathrm{O}_{2}-\mathrm{UO}_{2}-\mathrm{Na}$ Aerosols Produced by Vaporization of Fast Reactor Core Materials," BNL-12757, Brookhaven National Laboratory, August 1968.

4. W. C. Hinds, E. F. Mallove, and M. W. First, "Evaluation of In-Vessel Emergency Air Cleaning Systems for an LMFBR," CONF-760882, 14th ERDA Air Cleaning Conference, August 1976, p. 927.

5. R. E. Adams, T. S. Kress, and L. F. Parsly, Jr., "Sodium Oxide Aerosol Study: NSPP Runs 101-105, Data Record Report," ORNL/NUREG/TM-179, Oak Ridge National Laboratory, April 1978.

6. H. J. Ettinger, W. D. Moss, and H. Busey, "Characteristics of the Aerosol Produced From Burning Sodium and Plutonium," Nuc. Sc. \& Eng., 30, 1967, pp. 1-13.

7. W. 0. Schikarski, "The Aerosol Behavior in LMFBR Accidents: Results of TUNA Experimental Program and Comparison with PARDISEKO Code," Karlsruhe Nuclear Research Center, CONF-760882, 14th ERDA Air Cleaning Conference, August 1976, p. 885.

8. Y. Fruchard et al. "Sodium Fire Studies in France, Safety Tests and Applications on an LMFBR," CEA, Cadarache, CONF-7601001, Proceedings of International Meeting on Fast Reactor Safety and Related Physics, October 7976 , p. 1945.

9. S. Kitani et al. "Behavior of Sodium Oxide Aerosol in a Closed Chamber," J. Nuc. Sc. \& Tech., 10, September 1973, pp. 566-573.

10. J. F. van de Vate et a1. "Deposition of Aerosols Formed by HCDA Due to Decay Heat Transport in LMFBR Inner Containment Atmospheres," Netherlands Energy Research Foundation, CONF-761001, Proceedings of International Meeting on Fast Reactor Safety and Related Physics, October 1976, p. 1915.

11. R. K. Hilliard, J. D. McCormack, and A. K. Postma, "Evaluation of Air Cleaning System Concepts for Emergency Use in LMFBR Plants," HEDL-TME 76-41, Hanford Engineering Development Laboratory, December 1976. 
12. J. D. McCormack, A. K. Postma, and J. A. Schur, "Water Evolution From Heated Concrete," HEDL-TME 78-87, Hanford Engineering Development Laboratory, December 1978.

13. A. K. Postma and B. M. Johnson, "Containment Systems Experiment Final Program Summary," BNWL-1592, Batte11e, Pacific Northwest Laboratory, July 1971.

14. T. Gillespie and G. 0. Langstroth, Can. J. Chem., 30, 1952, p. 1056.

15. W. J. Megaw and A. C. Wel1s, "A High Resolution Charge and Mobility Spectrometer for Radioactive Submicrometric Aerosols," J. Sci. Instr., 2, 1969, pp. 1013-1020.

16. P. C. Reist and W. C. Hinds, "Optical Properties of Sodium Aerosols," CONF-700816, Proceedings of the 11th AEC Air Cleaning Conference, August 1970 , p. 425.

17. M. W. First and H. Yusa, "Heat Transfer of Sodium Compounds Deposited on Surfaces From Aerosols," CONF-700816, Proceedings of the 11th AEC Air Cleaning Conference, August 1970, p. 423.

18. R. N. Newman and C. A. Smith, "Sodium/Water Combustion and the Chemistry of Wastage at Sodium/Water Leak Sites," J. Nucl. Mat., 52, 1974, pp. 173-183.

19. R. N. Newman and C. A. Smith, "The Ignition of Sodium Metal, Sodium Peroxide Mixtures," J. Brit. Nucl. Energy Soc., 12(1), 1973, pp. 117-120.

20. Liquid Metals Handbook, 2nd ed., Atomic Energy Commission, Department of the Navy, Washington, DC, June 1952.

21. P. Beiriger et a1. "SOFIRE-II User Report," AI-AEC-13055, Atomics International, March 30, 1973.

22. R. S. Hubner et a1. "HAA-3 User Report," AI-AEC-13088, Atomics International, March 30, 1973.

23. L. D. Reed and J. A. Gieseke, "HAARM-3 Users Manual," BMI-X-665, Batte11e, Columbus Laboratories, October 31, 1975.

24. R. K. Hilliard, "Summary of HEDL Sodium Fire Tests," HEDL-SA 1669, Hanford Engineering Development Laboratory, November 1978. Paper presented at IAEA/IWGFR Specialists' Meeting on Sodium Fires and Prevention, Cadarache, France, November 20-24, 1978.

25. Chemical Engineer's Handbook, J. H. Perry (ed.), 3rd ed., McGraw-Hill Book Co., NY, 1950, p. 173.

26. J. A. Gieseke et al. "Characteristics of Agglomerates of Sodium Oxide Aerosol Particles," BMI-NUREG-1977, Batte11e, Columbus Laboratories, August 1977. 
APPENDIX A 
In this appendix, the suspended mass concentrations measured by each sample are presented for Tests $A B T$ and $A B 2$.

Aerosol concentrations measured from the four thief sampling stations ( $T-1$, $T-2, T-3$, and $T-4)$ are listed in Table $A-1$ for Test $A B 1$ and in Table $A-2$ for Test AB2. The masses are expressed in terms of sodium content alone. The concentration is expressed in terms of actual containment volume.

Aerosol concentrations, expressed as grams of sodium per actual cubic meter of contained gas, measured by 10 in-containment filter clusters, are listed in Table A-3 for Test $A B 1$; similar data for Test $A B 2$ are given in Table $A-4$. The in-vessel samplers gave results comparable to those obtained by the thief samples.

Total mass concentrations of aerosol, based on spatial average sodium concentrations and the sodium/total ratios plotted in Figure 16, are listed in Tables $A-5$ and $A-6$ for Tests $A B 1$ and $A B 2$, respectively. 
TABLE $A-1$

SUSPENDED SODIUM MASS CONCENTRATION MEASURED

BY THIEF FILTER SAMPLES - ABI

\begin{tabular}{|c|c|c|c|c|c|c|c|}
\hline \multirow[b]{2}{*}{$\operatorname{Time}_{(\mathrm{s})}^{(\mathrm{a})}$} & \multicolumn{6}{|c|}{$\begin{array}{c}\text { Concentration } \\
\left(\mathrm{g} \mathrm{Na} / \mathrm{m}^{3}\right)\end{array}$} & \multirow{2}{*}{$\begin{array}{c}\text { Standard } \\
\text { Deviation } \\
(\%)\end{array}$} \\
\hline & $\mathrm{Tl}^{(\mathrm{b})}$ & $\mathrm{T} 2$ & T3 & T4 & Mean & $\begin{array}{l}\text { Standard } \\
\text { Deviation }\end{array}$ & \\
\hline $\begin{array}{l}3.60(2) \\
6.00(2) \\
9.00(2) \\
1.50(3) \\
1.80(3)\end{array}$ & $\begin{array}{l}5.60(0) \\
6.00(0) \\
1.47(1) \\
1.11(1) \\
\text { (c) }\end{array}$ & $\begin{array}{l}5.76(0) \\
9.87(0) \\
1.34(1) \\
1.17(1) \\
1.28(1)\end{array}$ & $\begin{array}{l}6.65(0) \\
1.08(1) \\
(\mathrm{c}) \\
1.48(1) \\
1.31(1)\end{array}$ & $\begin{array}{l}4.46(0) \\
1.80(1) \\
1.49(1) \\
1.52(1) \\
\text { (c) }\end{array}$ & $\begin{array}{l}5.62(0) \\
1.12(1) \\
1.43(1) \\
1.32(1) \\
1.30(1)\end{array}$ & $\begin{array}{l}9.0(-1) \\
5.0(0) \\
8.3(-1) \\
2.1(0) \\
2.2(-1)\end{array}$ & $\begin{array}{l}16 \\
45 \\
5.6 \\
16 \\
1.7\end{array}$ \\
\hline $\begin{array}{l}2.40(3) \\
3.12(3) \\
3.60(3) \\
4.20(3) \\
4.80(3)\end{array}$ & $\begin{array}{l}2.27(1) \\
(c) \\
2.46(1) \\
(c) \\
9.05(0)\end{array}$ & $\begin{array}{l}1.37(1) \\
1.45(1) \\
1.50(1) \\
8.44(0) \\
5.16(0)\end{array}$ & $\begin{array}{l}1.31(1) \\
1.60(1) \\
1.60(1) \\
8.06(0) \\
5.39(0)\end{array}$ & $\begin{array}{l}1.45(1) \\
1.59(1) \\
1.72(1) \\
(\mathrm{c}) \\
5.83(0)\end{array}$ & $\begin{array}{l}1.60(1) \\
1.54(1) \\
1.82(1) \\
8.25(0) \\
6.36(0)\end{array}$ & $\begin{array}{l}4.5(0) \\
8.4(-1) \\
4.4(0) \\
2.7(-1) \\
1.8(0)\end{array}$ & $\begin{array}{l}28 \\
5.4 \\
24 \\
3.2 \\
28\end{array}$ \\
\hline $\begin{array}{l}5.40(3) \\
6.30(3) \\
7.20(3) \\
8.10(3) \\
9.00(3)\end{array}$ & $\begin{array}{l}5.93(0) \\
(c) \\
2.55(0) \\
1.42(0) \\
9.02(-1)\end{array}$ & $\begin{array}{l}3.62(0) \\
2.00(0) \\
1.44(0) \\
9.17(-1) \\
6.54(-1)\end{array}$ & $\begin{array}{l}3.76(0) \\
2.18(0) \\
1.55(0) \\
8.27(-1) \\
7.22(-1)\end{array}$ & $\begin{array}{l}3.87(0) \\
(c) \\
1.68(0) \\
9.34(-1) \\
5.86(-1)\end{array}$ & $\begin{array}{l}4.30(0) \\
2.09(0) \\
1.80(0) \\
1.02(0) \\
7.16(-1)\end{array}$ & $\begin{array}{ll}1.1 & (0) \\
1.3 & (-1) \\
5.1 & (-1) \\
2.7 & (-1) \\
1.4 & (-1)\end{array}$ & $\begin{array}{c}25 \\
6.1 \\
28 \\
26 \\
19\end{array}$ \\
\hline $\begin{array}{l}1.08(4) \\
1.29(4) \\
1.48(4) \\
1.62(4) \\
1.72(4)\end{array}$ & $\begin{array}{l}5.30(-1) \\
3.71(-1) \\
2.51(-1) \\
(c) \\
\text { (c) }\end{array}$ & $\begin{array}{l}4.40(-1) \\
3.03(-1) \\
(c) \\
1.60(-1) \\
(c)\end{array}$ & $\begin{array}{l}4.59(-1) \\
2.91(-1) \\
(c) \\
1.43(-1) \\
(c)\end{array}$ & $\begin{array}{l}3.87(-1) \\
3.03(-1) \\
1.83(-1) \\
(c) \\
1.52(-1)\end{array}$ & $\begin{array}{l}4.54(-1) \\
3.17(-1) \\
2.17(-1) \\
1.52(-1) \\
1.52(-1)\end{array}$ & $\begin{array}{ll}5.9 & (-2) \\
3.6 & (-2) \\
4.8 & (-2) \\
1.2 & (-2) \\
- & \end{array}$ & $\begin{array}{c}13 \\
12 \\
22 \\
7.9 \\
-\end{array}$ \\
\hline $\begin{array}{l}1.77(4) \\
1.93(4) \\
2.09(4) \\
2.60(4) \\
3.20(4)\end{array}$ & $\begin{array}{l}1.59(-1) \\
(c) \\
9.92(-2) \\
6.92(-2) \\
3.76(-2)\end{array}$ & $\begin{array}{l}(c) \\
8.42(-2) \\
(c) \\
6.16(-2) \\
1.65(-2)\end{array}$ & $\begin{array}{l}(c) \\
9.47(-2) \\
(c) \\
5: 14(-2) \\
(c)\end{array}$ & $\begin{array}{c}(c) \\
(c) \\
9.85(-2) \\
3.16(-2) \\
2.93(-2)\end{array}$ & $\begin{array}{l}1.59(-1) \\
8.95(-2) \\
9.89(-2) \\
5.60(-2) \\
2.78(-2)\end{array}$ & $\begin{array}{ll}- & \\
7.4 & (-3) \\
4.9 & (-4) \\
1.7 & (-2) \\
1.1 & (-2)\end{array}$ & $\begin{array}{l}- \\
8.3 \\
0.5 \\
30 \\
38\end{array}$ \\
\hline $\begin{array}{ll}3.80 & (4) \\
4.00 & (4) \\
4.60 & (4) \\
6.09 & (4) \\
7.38 & (4)\end{array}$ & $\begin{array}{r}2.93(-2) \\
(c) \\
1.62(-2) \\
7.52(-3) \\
8.02(-3)\end{array}$ & $\begin{array}{ll}2.11 & (-2) \\
2.03 & (-2) \\
1.47 & (-2) \\
7.50 & (-3) \\
4.51 & (-3)\end{array}$ & $\begin{array}{l}(c) \\
(c) \\
1.54(-2) \\
(c) \\
(c)\end{array}$ & $\begin{array}{l}2.41(-2) \\
(c) \\
1.39(-2) \\
7.33(-3) \\
5.39(-3)\end{array}$ & $\begin{array}{l}2.48(-2) \\
2.03(-2) \\
1.50(-2) \\
7.46(-3) \\
5.97(-3)\end{array}$ & $\begin{array}{cc}4.1 & (-3) \\
- & \\
9.8 & (-4) \\
1.0 & (-4) \\
1.8 & (-3)\end{array}$ & $\begin{array}{r}17 \\
6.5 \\
1.4 \\
31\end{array}$ \\
\hline $\begin{array}{l}8.70(4) \\
1.03(5) \\
1.08(5) \\
1.19(5) \\
1.27(5)\end{array}$ & $\begin{array}{l}1.29(-3) \\
2.72(-3) \\
(c) \\
1.31(-3) \\
9.42(-4)\end{array}$ & $\begin{array}{l}3.20(-3) \\
2.00(-3) \\
1.56(-3) \\
(c) \\
1.06(-3)\end{array}$ & $\begin{array}{l}2.88(-3) \\
2.02(-3) \\
1.54(-3) \\
(\mathrm{c}) \\
1.43(-3)\end{array}$ & $\begin{array}{r}2.71(-3) \\
2.00(-3) \\
(c) \\
1.36(-3) \\
1.11(-3)\end{array}$ & $\begin{array}{l}2.52(-3) \\
2.19(-3) \\
1.55(-3) \\
1.33(-3) \\
1.14(-3)\end{array}$ & $\begin{array}{ll}8.5 & (-4) \\
3.6 & (-4) \\
1.4 & (-5) \\
3.5 & (-5) \\
2.1 & (-4)\end{array}$ & $\begin{array}{l}33 \\
16 \\
0.9 \\
2.7 \\
18\end{array}$ \\
\hline $\begin{array}{l}1.35(5) \\
1.49(5) \\
1.82(5) \\
4.17(5) \\
4.27(5)\end{array}$ & $\begin{array}{l}(c) \\
7.07(-4) \\
(c) \\
6.6(-5) \\
(c)\end{array}$ & $\begin{array}{l}(c) \\
(c) \\
6.8(-4) \\
(c) \\
(c)\end{array}$ & $\begin{array}{l}1.11(-3) \\
8.08(-4) \\
4.7(-4) \\
\quad(c) \\
\quad(c)\end{array}$ & $\begin{array}{l}(c) \\
8.08(-4) \\
(c) \\
6.3(-5) \\
1.78(-2)\end{array}$ & $\begin{array}{l}1.11(-3) \\
7.74(-4) \\
5.8(-4) \\
6.45(-5) \\
1.78(-2)\end{array}$ & $\begin{array}{ll}- & \\
5.8 & (-5) \\
1.5 & (-4) \\
2.1 & (-6) \\
- & \end{array}$ & $\begin{array}{c}7.5 \\
26 \\
3.3 \\
-\end{array}$ \\
\hline $4.42(5)$ & $1.05(-2)$ & $(c)$ & (c) & (c) & $1.05(-2)$ & - & - \\
\hline
\end{tabular}

(a) Numbers in parentheses are exponents of base 10 .

(b) Location $\mathrm{Tl}$ is at elevation $+6.1 \mathrm{~m}$; T2 is at $+1.5 \mathrm{~m}$; T3 is at $+7.4 \mathrm{~m}$; and T4 is at $-5.8 \mathrm{~m}$. (c) No sample. 
TABLE A-2

SUSPENDED SODIUM MASS CONCENTRATION MEASURED BY THIEF FILTER SAMPLES - AB2

\begin{tabular}{|c|c|c|c|c|c|c|}
\hline \multirow[b]{2}{*}{$\begin{array}{c}\text { Time } \\
(\mathrm{s}) \\
\end{array}$} & \multicolumn{6}{|c|}{$\left(\mathrm{g} \mathrm{Na} / \mathrm{m}^{3}\right)^{2}$} \\
\hline & $T^{(b)}$ & $\mathrm{T} 2$ & $\mathrm{~T} 3$ & T4 & Mean & $\begin{array}{l}\text { Standard } \\
\text { Deviation }\end{array}$ \\
\hline $\begin{array}{l}3.60(2) \\
7.20(2) \\
1.02(3) \\
1.44(3) \\
1.80(3)\end{array}$ & $\begin{array}{l}\text { (c) } \\
(c) \\
(c) \\
(c) \\
(c)\end{array}$ & $\begin{array}{l}3.86(0) \\
9.76(0) \\
7.30(0) \\
1.12(1) \\
(\mathrm{c})\end{array}$ & $\begin{array}{l}5.91(0) \\
1.19(1) \\
(c) \\
8.78(0) \\
8.97(0)\end{array}$ & $\begin{array}{l}1.22(1) \\
(c) \\
(c) \\
9.48(0) \\
(c)\end{array}$ & $\begin{array}{l}7.32(0) \\
1.09(1) \\
7.30(0) \\
9.83(0) \\
8.97(0)\end{array}$ & $\begin{array}{l}4.34(0) \\
1.54(0) \\
- \\
1.26(0) \\
-\end{array}$ \\
\hline $\begin{array}{l}2.40(3) \\
3.24(3) \\
3.60(3) \\
4.32(3)\end{array}$ & $\begin{array}{l}(c) \\
(c) \\
(c) \\
(c)\end{array}$ & $\begin{array}{ll}7.72(0) \\
9.79(0) \\
9.82(0) \\
8.93(0)\end{array}$ & $\begin{array}{l}1.18(1) \\
1.24(1) \\
1.38(1) \\
9.29(0)\end{array}$ & $\begin{array}{c}1.32(1) \\
(c) \\
1.43(1) \\
(c)\end{array}$ & $\begin{array}{ll}1.09 & (1) \\
1.11 & (1) \\
1.26 & (1) \\
9.11 & (0)\end{array}$ & $\begin{array}{ll}2.86 & (0) \\
1.84 & (0) \\
2.45(0) \\
2.50(-1)\end{array}$ \\
\hline $\begin{array}{l}4.80(3) \\
5.40(3) \\
6.30(3) \\
7.20(3) \\
8.20(3)\end{array}$ & $\begin{array}{l}(c) \\
(c) \\
3.74(0) \\
2.50(0) \\
(c)\end{array}$ & $\begin{array}{l}5.42(0) \\
3.64 \\
2.37(0) \\
2.01 \\
2.010) \\
2.34(0)\end{array}$ & $\begin{array}{l}7.02(0) \\
4.93(0) \\
3.42(0) \\
2.04(0) \\
1.56(0)\end{array}$ & $\begin{array}{l}(c) \\
(c) \\
3.51(0) \\
2.42(0) \\
(c)\end{array}$ & $\begin{array}{l}6.22(0) \\
4.29(0) \\
3.26(0) \\
2.24(0) \\
1.92(0)\end{array}$ & $\begin{array}{ll}1.13 & (0) \\
9.10 & (-1) \\
6.08 & (-1) \\
2.54 & (-1) \\
5.90 & (-1)\end{array}$ \\
\hline $\begin{array}{l}9.00(3) \\
1.13(4) \\
1.29(4) \\
1.47(4) \\
1.63(4)\end{array}$ & $\begin{array}{l}1.45(0) \\
9.43(-1) \\
3.29(-1) \\
2.35(-1) \\
\text { (c) }\end{array}$ & $\begin{array}{l}2.50(0) \\
4.79(-1) \\
3.06(-1) \\
(c) \\
2.44(-1)\end{array}$ & $\begin{array}{l}1.24(0) \\
7.30(-1) \\
2.60(-1) \\
(c) \\
2.62(-1)\end{array}$ & $\begin{array}{l}1.25(0) \\
4.82(-1) \\
3.16(-1) \\
3.37(-1) \\
2.53(-1)\end{array}$ & $\begin{array}{ll}1.61 & (0) \\
6.58(-1) \\
3.03(-1) \\
2.86(-1) \\
2.53(-1)\end{array}$ & $\begin{array}{l}6.01(-1) \\
2.28(-1) \\
3.00(-2) \\
7.20(-2) \\
9.0(-3)\end{array}$ \\
\hline $\begin{array}{l}1.94(4) \\
2.53(4) \\
3.21(4) \\
3.75(4) \\
4.50(4)\end{array}$ & $\begin{array}{l}1.63(-1) \\
1.06(-1) \\
7.30(-2) \\
5.4(-2) \\
3.0(-2)\end{array}$ & $\begin{array}{l}2.11(-1) \\
1.25(-1) \\
7.1(-2) \\
4.3(-2) \\
3.2(-2)\end{array}$ & $\begin{array}{l}2.01(-1) \\
1.32(-1) \\
(c) \\
(c) \\
3.8(-2)\end{array}$ & $\begin{array}{l}1.77(-1) \\
1.17(-1) \\
6.8(-2) \\
5.0(-2) \\
3.1(-2)\end{array}$ & $\begin{array}{l}1.88(-1) \\
1.20(-1) \\
7.07(-2) \\
4.9(-2) \\
3.28(-2)\end{array}$ & $\begin{array}{l}2.19(-2) \\
1.11(-2) \\
2.52(-3) \\
5.57(-3) \\
3.60(-3)\end{array}$ \\
\hline $\begin{array}{l}6.06(4) \\
7.35(4) \\
8.61(4) \\
9.60(4) \\
1.10(5)\end{array}$ & $\begin{array}{l}2.08(-2) \\
1.7(-2) \\
1.0(-2) \\
4.6(-3) \\
5.7(-3)\end{array}$ & $\begin{array}{ll}2.0 & (-2) \\
1.4 & (-2) \\
1.1 & (-2) \\
9.6 & (-3) \\
5.9 & (-3)\end{array}$ & $\begin{array}{ll}2.3 & (-2) \\
1.6 & (-2) \\
1.0 & (-2) \\
7.5 & (-3) \\
5.8 & (-3)\end{array}$ & $\begin{array}{l}1.8(-2) \\
1.6(-2) \\
1.2(-2) \\
8.8(-3) \\
6.8(-3)\end{array}$ & $\begin{array}{l}2.05(-2) \\
1.57(-2) \\
1.08(-2) \\
7.63(-3) \\
6.05(-3)\end{array}$ & $\begin{array}{ll}2.07 & (-3) \\
1.25(-3) \\
9.1(-4) \\
2.2(-3) \\
5.1(-4)\end{array}$ \\
\hline $\begin{array}{l}1.28(5) \\
1.46(5) \\
1.73(5) \\
1.91(5) \\
4.02(5)\end{array}$ & $\begin{array}{l}4.4(-3) \\
3.0(-3) \\
2.0(-3) \\
(c) \\
1.65(-4)\end{array}$ & $\begin{array}{l}6.5(-3) \\
(c)^{(-3)} \\
1.8(-3) \\
1.4(-3) \\
(c)^{(3)}\end{array}$ & $\begin{array}{c}4.2(-3) \\
3.0(-3) \\
2.1(-3) \\
1.6(-3) \\
(c)\end{array}$ & $\begin{array}{l}4.7(-3) \\
3.5(-3) \\
2.7(-3) \\
(c) \\
1.8(-4)\end{array}$ & $\begin{array}{l}4.95(-3) \\
3.17(-3) \\
2.15(-3) \\
1.5(-3) \\
1.72(-4)\end{array}$ & $\begin{array}{l}1.05(-3) \\
2.9(-4) \\
3.9(-4) \\
1.4(-4) \\
1.1(-5)\end{array}$ \\
\hline $4.43(5)$ & $<2.0(-5)$ & $<2.3(-5)$ & $<3.0(-5)$ & $<2.0(-5)$ & $<3.0(-5)$ & - \\
\hline
\end{tabular}




\section{TABLE A-3}

\section{SUSPENDED SODIUM MASS CONCENTRATION MEASURED BY CLUSTER FILTERS - ABI}

\begin{tabular}{|c|c|c|c|c|c|c|c|c|c|c|c|}
\hline \multirow{2}{*}{$\begin{array}{c}\text { Cluster (a) } \\
\text { Number }\end{array}$} & \multicolumn{11}{|c|}{ Concentration $\left(\mathrm{g} \mathrm{Na} / \mathrm{m}^{3}\right)$ at Specified Time $(\mathrm{s})$} \\
\hline & $3.60(2) \mathrm{s}$ & $9.00(2) \mathrm{s}$ & $1.50(3) s$ & $2.40(3) \mathrm{s}$ & $3.60(3) s$ & $4.80(3) \mathrm{s}$ & $7.20(3) \mathrm{s}$ & $1.08(4) \mathrm{s}$ & $1.83(4) \cdot \mathrm{s}$ & $3.81(4) \mathrm{s}$ & $8.43(4) s$ \\
\hline $\mathrm{Cl}$ & $1.71(0)^{(b)}$ & $1.13(1)$ & $1.25(1)$ & $8.23(0)$ & $9.56(0)$ & (c) & $1.41(0)$ & $4.77(-1)$ & $1.89(-1)$ & $4.44(-2)$ & $7.61(-3)$ \\
\hline $\mathrm{C} 2$ & $1.80(0)$ & $1.18(1)$ & $1.28(1)$ & $7.80(0)$ & $9.59(0)$ & $5.04(0)$ & $1.39(0)$ & $7.91(-1)$ & $4.14(-1)$ & $1.13(-1)$ & (c) \\
\hline $\mathrm{C} 3$ & $2.25(0)$ & 1.04 (1) & $1.25(1)$ & $8.05(0)$ & $1.17(1)$ & $5.62(0)$ & $1.63(0)$ & $9.48(-1)$ & (c) & $1.22(-1)$ & $6.27(-3)$ \\
\hline$C 4$ & $1.89(0)$ & $1.07(1)$ & $9.42(0)$ & $8.58(0)$ & $9.56(0)$ & $4.24(0)$ & $3.26(0)$ & $7.28(-1)$ & $4.03(-1)$ & $8.38(-2)$ & $8.78(-3)$ \\
\hline$C 5$ & $2.61 \quad(0)$ & 1.07 (1) & $1.10(1)$ & $1.02(1)$ & $1.24(1)$ & $5.69(0)$ & $2.86(0)$ & (c) & (c) & (c) & (c) \\
\hline c6 & $1.89(1)$ & $1.07(1)$ & $1.19(1)$ & $7.88(0)$ & $1.06(1)$ & $4.07(0)$ & $1.50(0)$ & $7.72(-1)$ & $3.40(-1)$ & $7.82 \cdot(-2)$ & $1.10(-2)$ \\
\hline$C 7$ & $3.33(0)$ & $1.04(1)$ & $1.08(1)$ & $9.11(0)$ & $1.11(1)$ & $4.93(0)$ & $1.79(0)$ & $6.40(-1)$ & $3.68(-1)$ & $8.45(-2)$ & $1.14(-2)$ \\
\hline$C 8$ & $2.48(0)$ & $1.04(1)$ & $9.42(0)$ & $7.88(0)$ & $8.89(1)$ & $3.48(0)$ & $1.06(0)$ & $4.39(-1)$ & $1.15(-1)$ & $2.89(-2)$ & $3.59(-3)$ \\
\hline 69 & $2.07(0)$ & $1.14(1)$ & $1.19(1)$ & $8.94(0)$ & $7.10(1)$ & $3.73(0)$ & $1.15(0)$ & $4.90(-1)$ & $1.37(-1)$ & $4.01(-2)$ & $3.85(-3)$ \\
\hline $\mathrm{ClO}$ & $2.07(0)$ & 1.04 (1) & $1.17(1)$ & $8.94(0)$ & $8.86(1)$ & $3.21(0)$ & $9.93(-1)$ & $4.39(-1)$ & $1.97(-1)$ & $6.27(-2)$ & $5.27(-3)$ \\
\hline MEAN & $2.21(0)$ & $1.08(1)$ & $1.14(1)$ & $8.53(0)$ & $9.94(0)$ & $4.45(0)$ & $1.50(0)$ & $6.34(-1)$ & $2.70(-1)$ & $7.31 \quad(-2)$ & $7.21(-3)$ \\
\hline $\begin{array}{l}\text { STANDARD } \\
\text { DEVIATION }\end{array}$ & $\begin{array}{c}4.8(-1) \\
(22 \%)\end{array}$ & $\begin{array}{c}4.8(-1) \\
(4.4 \%)\end{array}$ & $\begin{array}{c}1.22(0) \\
(11 \%)\end{array}$ & $\begin{array}{c}7.9(-1) \\
(9.3 \%)\end{array}$ & $\begin{array}{c}1.54(0) \\
(15 \%)\end{array}$ & $\frac{9.1(-1)}{(20 \%)}$ & $\begin{array}{c}5.4(-1) \\
(36 \%)\end{array}$ & $\frac{1.84(-1)}{(29 \%)}$ & $\begin{array}{l}1.23(-1) \\
(46 \%)\end{array}$ & $\begin{array}{c}2.95(-2) \\
(44 \%)\end{array}$ & $\begin{array}{c}3.0(-3) \\
(42 \%)\end{array}$ \\
\hline
\end{tabular}

Ta) See Figure E-1 for coordinates.

(b) Numbers in parentheses are exponents of base 10 .

(c) Sample lost. 
TABLE $A-4$

\section{SUSPENDED SODIUM MASS CONCENTRATION MEASURED BY CLUSTER FILTERS - AB2}

\begin{tabular}{|c|c|c|c|c|c|c|c|c|c|c|c|}
\hline \multirow{2}{*}{$\begin{array}{c}\text { Cluster }(\mathrm{a}) \\
\text { Number }\end{array}$} & \multicolumn{11}{|c|}{ Concentration $\left(\mathrm{g} \mathrm{Na} / \mathrm{m}^{3}\right)$ at Specified Time $(\mathrm{s})$} \\
\hline & 3.60 (2) $\mathrm{s}$ & $1.14(3) \mathrm{s}$ & $1.62(3) \mathrm{s}$ & $2.40(3) \mathrm{s}$ & $3.60(3) \mathrm{s}$ & $4.80(3) \mathrm{s}$ & $7.20(3) \mathrm{s}$ & $1.08(4) \mathrm{s}$ & $1.80(4) \mathrm{s}$ & 3.60 (4) $\mathrm{s}$ & $8.37(4) \mathrm{s}$ \\
\hline $\mathrm{Cl}$ & $7.40(0)^{(\mathrm{D})}$ & $8.24(0)$ & (c) & $9.71(0)$ & $1.09(1)$ & $4.26(0)$ & $3.60(0)$ & $9.34(-1)$ & $3.18(-1)$ & $4.67(-2)$ & $1.77(-2)$ \\
\hline $\mathrm{C} 2$ & $7.23(0)$ & $8.64(0)$ & $7.17(0)$ & $8.30(0)$ & (c) & $3.13(0)$ & $4.10(0)$ & $1.10(0)$ & $4.67(-1)$ & $7.74(-2)$ & $9.20(-3)$ \\
\hline $\mathrm{C3}$ & $7.18(0)$ & $1.03(1)$ & $1.03(1)$ & $1.15(1)$ & $1.15(1)$ & $5.84(0)$ & $2.19(0)$ & $1.77(0)$ & (c) & $1.19(-1)$ & $1.57(-2)$ \\
\hline $\mathrm{C4}$ & $.7 .71 \quad(0)$ & $1.04(1)$ & $8.77(0)$ & $1.01(1)$ & $1.19(1)$ & $5.92(0)$ & $3.70(0)$ & $9.70(-1)$ & $3.39(-1)$ & $1.06(-1)$ & $1.01(-2)$ \\
\hline$C 5$ & (c) & $8.36(0)$ & $7.29(0)$ & $8.44(0)$ & $9.29(0)$ & $2.91(0)$ & $2.70(0)$ & $1.01(0)$ & $2.11(-1)$ & $4.90(-2)$ & $8.49(-3)$ \\
\hline C6 & $7.05(0)$ & $7.92(0)$ & $7.07(0)$ & $8.63(0)$ & $1.13(1)$ & $1.00(1)$ & (c) & $5: 88(-1)$ & $3.73(-1)$ & $4.83(-2)$ & $6.19(-3)$ \\
\hline$C 7$ & $6.66(0)$ & $7.93(0)$ & $8.77(0)$ & $1.02(1)$ & $1.44(1)$ & $6.36(0)$ & $2.71(0)$ & $1.00(0)$ & $3.02(-1)$ & $8.50(-2)$ & $8.85(-3)$ \\
\hline$C 8 \therefore$ & $5.80 \ldots(0)$ & $6.11-(0)$ & $\ldots 6 . .49(0)$ & $7.84(0)$ & $9.46(0)$ & (c) & (c) & $4.78(-1)$ & $1.89(-1)$ & $4.75(-2)$ & $8.85(-3)$ \\
\hline C9 & $6.41(0)$ & $7.70(0)$ & $6.88(0)$ & $7.84(0)$ & $8.93(0)$ & (c) & $1.84(0)$ & (c) & $4.22(-1)$ & $5.44(-2)$ & $8.49(-3)$ \\
\hline $\mathrm{C} 10$ & $6.90(0)$ & $1.02(1)$ & $1.16(1)$ & $1.01(1)$ & $1.32(1)$ & $\underline{6.43(0)}$ & $2.77(0)$ & $1.38(0)$ & (c) & (c) & $1.84(-2)$ \\
\hline MEAN & $6.92(0)$ & $8.59(0)$ & $8.26(0)$ & $9.28(0)$ & $1.12(1)$ & $5.62(0)$ & $2.84(0)$ & $9.56(-1)$ & $3.27(-1)$ & $7.04(-2)$ & $1.12(-2)$ \\
\hline $\begin{array}{l}\text { STANDARD } \\
\text { DEVIATION }\end{array}$ & $\begin{array}{c}5.74(-1) \\
(8.3 \%)\end{array}$ & $\begin{array}{c}1.37-(0) \\
(16 \%)\end{array}$ & $\begin{array}{l}1.74(0) \\
(21 \%)\end{array}$ & $\begin{array}{l}1.24(0) \\
(13 \%)\end{array}$ & $\begin{array}{c}1.82(0) \\
(16 \%)\end{array}$ & $\begin{array}{c}2.28(0) \\
(40 \%)\end{array}$ & $\begin{array}{c}7.96(-1) \\
(28 \%)\end{array}$ & $\frac{2.79(-1)}{(29 \%)}$ & $\begin{array}{c}9.59(-2) \\
(29 \%)\end{array}$ & $\begin{array}{l}2.78(-2) \\
(40 \%)\end{array}$ & ${ }^{4.36(39 \%)}(-3)$ \\
\hline
\end{tabular}

(a) See Figure E-1 for coordinates.

(b) Numbers in parentheses are exponents of base 10 .

(c) Sample lost. 
TABLE A-5

SUSPENDED TOTAL MASS CONCENTRATION - TEST AB1

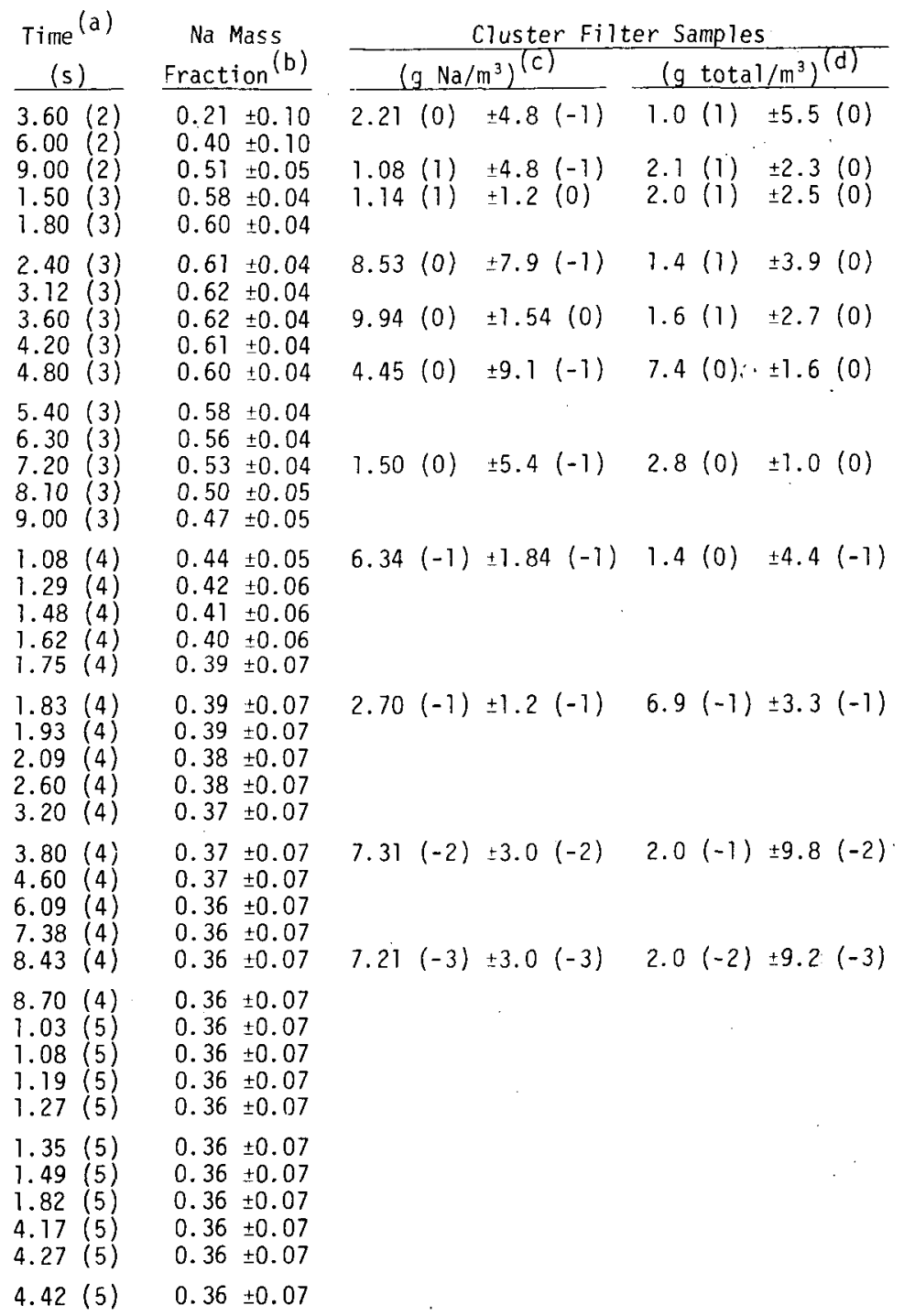

\begin{tabular}{|c|c|c|c|}
\hline \multicolumn{2}{|c|}{$\left(\mathrm{g} \mathrm{Na} / \mathrm{m}^{3}\right)^{(\mathrm{c})}$} & \multicolumn{2}{|c|}{$\left(g \text { total } / \mathrm{m}^{3}\right)^{(\mathrm{d})}$} \\
\hline $\begin{array}{l}5.62(0) \\
1.12(1) \\
1.43(1) \\
1.32(1) \\
1.30(1)\end{array}$ & $\begin{array}{l} \pm 9.0(-1) \\
\pm 5.0(0) \\
\pm 8.3(-1) \\
\pm 2.1(0) \\
\pm 2.2(-1)\end{array}$ & $\begin{array}{l}2.7(1) \\
2.8(1) \\
2.8(1) \\
2.3(1) \\
2.2(1)\end{array}$ & $\begin{array}{l} \pm 1.3(1) \\
\pm 1.4(1) \\
\pm 3.5(0) \\
\pm 4.0(0) \\
\pm 1.5(0)\end{array}$ \\
\hline $\begin{array}{l}60(1) \\
54(1) \\
82(1) \\
25(0) \\
36(0)\end{array}$ & $\begin{array}{l} \pm 4.5(0) \\
\pm 8.4(-1) \\
\pm 4.4(0) \\
\pm 2.7(-1) \\
\pm 1.8(0)\end{array}$ & $\begin{array}{l}2.6(1) \\
2.5(1) \\
2.9(1) \\
1.3(1) \\
1.0(1)\end{array}$ & $\begin{array}{l} \pm 7.5(0) \\
\pm 2.1(0) \\
\pm 7.3(0) \\
\pm 1.0(0) \\
\pm 2.9(0)\end{array}$ \\
\hline $\begin{array}{l}.30(0) \\
.09(0) \\
.80(0) \\
.02(0) \\
.16(-1)\end{array}$ & $\begin{array}{l} \pm 1.7(0) \\
\pm 1.3(-1) \\
\pm 5.7(-1) \\
\pm 2.7(-1) \\
\pm 7.4(-1)\end{array}$ & $\begin{array}{l}7.4(0) \\
3.7(0) \\
3.4(0) \\
2.0(0) \\
1.5(0)\end{array}$ & $\begin{array}{l} \pm 2.0(0) \\
\pm 3.5(-1 \\
\pm 1.0(0) \\
\pm 5.7(-7 \\
\pm 3.3(-1\end{array}$ \\
\hline $\begin{array}{l}2.17(-1) \\
1.52(-1) \\
1.55(-1)\end{array}$ & $\begin{array}{l} \pm 5.9(-2) \\
\pm 3.6(-2) \\
\pm 4.8(-2) \\
\pm 1.2(-2) \\
\pm 5.0(-3)\end{array}$ & $\begin{array}{l}1.0(0) \\
7.5(-1) \\
5.3(-1) \\
3.8(-1) \\
4.0(-1)\end{array}$ & $\begin{array}{l} \pm 1.51- \\
\pm 1.4(- \\
\pm 6.4(- \\
\pm 7.3\end{array}$ \\
\hline
\end{tabular}

$8.95(-2) \pm 7.4(-3)$

$2.3(-1) \pm 4.5(-2)$

$9.89(-2) \pm 4.9(-4)$

$5.60(-2) \pm 1.7(-2)$

$2.78(-2) \pm 1.7(-2)$

$2.6(-1) \pm 4.8(-2)$

$1.5(-1) \pm 5.3(-2)$

$7.5(-2) \pm 3.3(-2)$

$2.48(-2) \pm 4.1(-3)$

$6.7(-2) \pm 3.5(-2)$

$1.50(-2) \pm 9.8(-4) \quad 4.0(-2) \pm 8.0(-3)$

$7.46(-3) \pm 1.0(-4) \quad 2.1(-2) \pm 4.1(-3)$

$2.52(-3) \pm 8.5(-4)$

$2.19(-3) \pm 3.6(-4)$

$1.55(-3) \pm 1.4(-5)$
$1.33(-3) \pm 3.5(-5)$

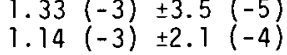

$1.11(-3) \pm 2.0(-4)$

$7.74(-4) \pm 5.8(-5)$

$5.8(-4) \pm 1.5(-4)$

$6.45(-5) \pm 2.7(-6)$

$1.78(-2) \pm 3.5(-3)$

$1.7(-2) \pm 6.1(-3)$

$1.05(-2) \pm 3.0(-3)$

$7.0(-3) \pm 2.7(-3)$

$6.1(-3) \pm 1.6(-3)$

$4.3(-3) \pm 8.4(-4)$

$3.7(-3)+ \pm 6.5(-4)$

$3.2(-3) \pm 8.5(-4)$

$3.1(-3) \pm 8.2(-4)$

$2.2(-3) \pm 4.6(-4)$

$1.6(-3) \pm 5.2(-4)$

$1.8(-4) \pm 3.3(-5)$

$4.9(-2) \pm 7.4(-2)$

$2.9(-2) \pm 1.0(-2)$

(a) Numbers in parentheses are exponents of base 10 .

(b) Taken from Figure 16.

(c) Taken from Tables A-1 and A-3.

(d) Total mass concentration = sodium mass concentration $\div$ sodium mass fraction. 
TABLE $A-6$

\section{SUSPENDED TOTAL MASS CONCENTRATION - TEST AB2}

\begin{tabular}{|c|c|c|c|c|c|}
\hline \multirow{2}{*}{$\begin{array}{c}\operatorname{Time}^{(a)} \\
(\mathrm{s})\end{array}$} & \multirow[b]{2}{*}{ Fraction $^{(b)}$} & \multicolumn{4}{|c|}{ Cluster Filter Samples } \\
\hline & & (g Na & $\left(m^{3}\right)^{(c)}$ & (g tot & $\left.a 1 / m^{3}\right)(d)$ \\
\hline $\begin{array}{ll}3.60 & (2) \\
7.20 & (2) \\
1.02 & (3) \\
1.14 & (3) \\
1.44 & (3)\end{array}$ & $\begin{array}{l}0.42 \pm 0.04 \\
0.49 \pm 0.04 \\
0.49 \pm 0.04 \\
0.48 \pm 0.04 \\
0.45 \pm 0.04\end{array}$ & $6.92(0)$ & $\pm 5.7(-1)$ & $1.65(1)$ & $\pm 2.1(0)$ \\
\hline $\begin{array}{ll}1.62 & (3) \\
1.80 & (3) \\
2.40 & (3) \\
3.24 & (3) \\
3.60 & (3)\end{array}$ & $\begin{array}{l}0.44 \pm 0.04 \\
0.43 \pm 0.04 \\
0.40 \pm 0.04 \\
0.39 \pm 0.04 \\
0.35 \pm 0.04\end{array}$ & $\begin{array}{l}8.26(0) \\
9.28(0)\end{array}$ & $\pm 1.2(0)$ & $2.32(1)$ & $\begin{array}{l} \pm 4.2(0) \\
\pm 3.8(0) \\
\pm 6.3(0)\end{array}$ \\
\hline $\begin{array}{ll}4.32 & (3) \\
4.80 & (3) \\
5.40 & (3) \\
6.30 & (3) \\
7.20 & (3)\end{array}$ & $\begin{array}{l}0.29 \pm 0.03 \\
0.27 \pm 0.03 \\
0.27 \pm 0.03 \\
0.27 \pm 0.03 \\
0.28 \pm 0.04\end{array}$ & $2.84(0)$ & $\begin{array}{l} \pm 2.3(0) \\
\pm 8.0(-1)\end{array}$ & $\begin{array}{l}2.08(1) \\
1.0(1)\end{array}$ & $\pm 3.2(0)$ \\
\hline $\begin{array}{l}8.20(3) \\
9.00(3) \\
1.08(4) \\
1.13(4) \\
1.29(4)\end{array}$ & $\begin{array}{l}0.28 \pm 0.04 \\
0.28 \pm 0.04 \\
0.28 \pm 0.04 \\
0.28 \pm 0.04 \\
0.28 \pm 0.04\end{array}$ & $9.56(-1)$ & $\pm 2.8(-1)$ & $3.32(0)$ & $\pm 1.7(0)$ \\
\hline $\begin{array}{l}1.47(4) \\
1.63(4) \\
1.80(4) \\
1.94 \quad(4) \\
2.53(4)\end{array}$ & $\begin{array}{l}0.28 \pm 0.04 \\
0.28 \pm 0.04 \\
0.29 \pm 0.04 \\
0.29 \pm 0.04 \\
0.30 \pm 0.04\end{array}$ & $3.27(-1)$ & $\pm 9.6(-2)$ & $1.13(0)$ & $\pm 3.7(-1)$ \\
\hline $\begin{array}{ll}3.21 & (4) \\
3.60 & (4) \\
3.75 & (4) \\
4.50 & (4) \\
6.06 & (4)\end{array}$ & $\begin{array}{l}0.30 \pm 0.04 \\
0.30 \pm 0.04 \\
0.30 \pm 0.04 \\
0.30 \pm 0.04 \\
0.31 \pm 0.04\end{array}$ & $7.04(-2)$ & $\pm 2.8(-2)$ & $2.35(-1)$ & $\pm 9.9(-2)$ \\
\hline $\begin{array}{l}7.35 \\
8.37(4) \\
8.61 \quad(4) \\
9.60(4) \\
1.10(5)\end{array}$ & $\begin{array}{ll}0.31 & \pm 0.05 \\
0.31 & \pm 0.05 \\
0.31 & \pm 0.05 \\
0.32 & \pm 0.05 \\
0.32 & \pm 0.05\end{array}$ & $1.12(-2)$ & $\pm 4.4(-3)$ & $3.61(-2)$ & $\pm 1.5(-2)$ \\
\hline $\begin{array}{l}1.28(5) \\
1.46(5) \\
1.73(5) \\
1.91(5) \\
4.02 \quad(5)\end{array}$ & $\begin{array}{l}0.32 \pm 0.05 \\
0.32 \pm 0.05 \\
0.32 \pm 0.05 \\
0.32 \pm 0.05 \\
0.34 \pm 0.05\end{array}$ & & & & \\
\hline $4.43(5)$ & $0.34 \pm 0.05$ & & & & \\
\hline
\end{tabular}

\begin{tabular}{|c|c|c|c|}
\hline$\left(\mathrm{g} \mathrm{Na} / \mathrm{m}^{3}\right)^{(\mathrm{C})}$ & \multicolumn{2}{|c|}{ Thief Filter Samples } & $\left(g \text { tota } 1 / m^{3}\right)^{(d)}$ \\
\hline $\begin{array}{l}7.32(0) \\
1.09(1) \\
7.30(0)\end{array}$ & $\begin{array}{l} \pm 4.3(0) \\
\pm 1.5(0) \\
\pm 1.5(0)\end{array}$ & $\begin{array}{l}1.74(1) \\
2.22(1) \\
1.49(1)\end{array}$ & $\begin{array}{l} \pm 1.0(1) \\
\pm 3.6(0) \\
\pm 3.3(0)\end{array}$ \\
\hline $9.83(0)$ & $\pm 1.3(0)$ & $2.18(1)$ & $\pm 3.5(0)$ \\
\hline $\begin{array}{l}8.97(0) \\
1.09(1) \\
1.11(1) \\
1.26(1)\end{array}$ & $\begin{array}{l} \pm 1.5(0) \\
\pm 2.9(0) \\
\pm 1.8(0) \\
\pm 2.5(0)\end{array}$ & $\begin{array}{l}2.22(1) \\
2.73(1) \\
2.85(1) \\
3.60(1)\end{array}$ & $\begin{array}{l} \pm 4.2(0) \\
\pm 7.8(0) \\
\pm 5.5(0) \\
\pm 8.2(0)\end{array}$ \\
\hline $\begin{array}{l}9.11(0) \\
6.22(0) \\
4.29(0) \\
3.26(0) \\
2.24(0)\end{array}$ & $\begin{array}{l} \pm 2.5(-1) \\
\pm 1.1(0) \\
\pm 9.1(-1) \\
\pm 6.1(-1) \\
\pm 2.5(-1)\end{array}$ & $\begin{array}{l}3.14(1) \\
2.30(1) \\
1.59(1) \\
1.21(1) \\
8.00(0)\end{array}$ & $\begin{array}{l} \pm 3.4(0) \\
\pm 4.8(0) \\
\pm 3.8(0) \\
\pm 2.6(0) \\
\pm 1.4(0)\end{array}$ \\
\hline $\begin{array}{l}1.92(0) \\
1.61(0)\end{array}$ & $\begin{array}{l} \pm 5.9(-1) \\
\pm 6.0(-1)\end{array}$ & $\begin{array}{l}6.86(0) \\
5.75(0)\end{array}$ & $\begin{array}{l} \pm 2.3(0) \\
\pm 2.3(0)\end{array}$ \\
\hline $\begin{array}{l}6.58(-1) \\
3.03(-1)\end{array}$ & $\begin{array}{l} \pm 2.3(-1) \\
\pm 3.0(-2)\end{array}$ & $\begin{array}{l}2.35(0) \\
1.08(0)\end{array}$ & $\begin{array}{l} \pm 8.9(-1) \\
\pm 1.9(-1)\end{array}$ \\
\hline $\begin{array}{l}2.86(-1) \\
2.53(-1)\end{array}$ & $\begin{array}{l} \pm 7.2(-2) \\
\pm 9.0(-3)\end{array}$ & $\begin{array}{l}1.02(0) \\
9.05(-1)\end{array}$ & $\begin{array}{l} \pm 3.0(-1) \\
\pm 1.3(-1)\end{array}$ \\
\hline $\begin{array}{l}1.88(-1) \\
1.20(-1)\end{array}$ & $\begin{array}{l} \pm 2.2(-2) \\
\pm 7.1(-2)\end{array}$ & $\begin{array}{l}6.48(-1) \\
4.00(-1)\end{array}$ & $\begin{array}{l} \pm 1.2(-1) \\
\pm 6.5(-2)\end{array}$ \\
\hline $7.07(-2)$ & $\pm 2.5(-3)$ & $2.35(-1)$ & $\pm 3.2(-2)$ \\
\hline $\begin{array}{l}4.90(-2) \\
3.28(-2) \\
2.05(-2)\end{array}$ & $\begin{array}{l} \pm 5.6(-3) \\
\pm 3.6(-3) \\
\pm 2.1(-3)\end{array}$ & $\begin{array}{l}1.63(-1) \\
1.09(-1) \\
6.61(-2)\end{array}$ & $\begin{array}{l} \pm 2.9(-2) \\
\pm 1.9(-2) \\
\pm 1.1(-2)\end{array}$ \\
\hline $1.57(-2)$ & $\pm 1.2(-3)$ & $5.06(-2)$ & $\pm 9.0(-3)$ \\
\hline $\begin{array}{l}1.08(-2) \\
7.63(-3) \\
6.05(-3)\end{array}$ & $\begin{array}{l} \pm 9.1(-4) \\
\pm 2.2(-3) \\
\pm 5.7(-4)\end{array}$ & $\begin{array}{l}3.48(-2) \\
2.38(-2) \\
1.89(-2)\end{array}$ & $\begin{array}{l} \pm 6.3(-3) \\
\pm 7.8(-3) \\
\pm 3.3(-3)\end{array}$ \\
\hline $\begin{array}{l}4.95(-3) \\
3.17(-3) \\
2.15(-3) \\
1.50(-3) \\
1.72(-4)\end{array}$ & $\begin{array}{l} \pm 1.1(-3) \\
\pm 2.9(-4) \\
\pm 3.9(-4) \\
\pm 1.4(-4) \\
\pm 1.1\end{array}$ & $\begin{array}{l}1.55(-2) \\
1.02(-2) \\
6.72(-3) \\
4.69(-3) \\
5.06(-4)\end{array}$ & $\begin{array}{l} \pm 4.2(-3) \\
\pm 1.8(-3) \\
\pm 1.6(-3) \\
\pm 8.6(-4) \\
\pm 8.0(-5)\end{array}$ \\
\hline$-3.0(-5)$ & & $<8.8(-5)$ & \\
\hline
\end{tabular}

\footnotetext{
(a) Numbers in parentheses are exponents of base 10.

(b) Taken from Figure 16

(c) Taken from Tables $A-2$ and $A-4$.

(d) Total mass concentration = sodium mass concentration $\div$ sodium mass fraction.
} 
APPENDIX B 
In this appendix, data for the individual cascade impactor measurements are presented as well as the calculational procedures used to extract size data from the stage deposits. The collection characteristics of each impactor stage were assumed to be controlled by the dimensionless impaction parameter:

$$
\psi=\frac{\rho \nu d^{2} C}{18 \mu D}
$$

Where:

$$
\begin{aligned}
& \psi=\text { Impaction parameter (dimensionless), } \\
& \nu=\text { Gas velocity }(\mathrm{cm} / \mathrm{s}), \\
& \rho=\text { Particle density }\left(\mathrm{g} / \mathrm{cm}^{3}\right), \\
& d=\text { Particle diameter }(\mathrm{cm}), \\
& \mu=\text { Gas viscosity }(\mathrm{g} / \mathrm{cm} \mathrm{s}), \\
& D=\text { Impactor jet diameter }(\mathrm{cm}), \text { and } \\
& C=\text { Cunningham slip factor (dimensionless). }
\end{aligned}
$$

At the point of the impaction curve where $50 \%$ of the particles are collected, the impaction parameter $\psi$ takes the value $\psi_{50}$. The $50 \%$ size is thus:

$$
d_{50}=\left(\frac{18 \mu D \psi_{50}}{\rho \nu C}\right)^{0.5}
$$

Where:

$$
\begin{aligned}
d_{50}= & \text { Particle diameter at } 50 \% \text { point on efficiency versus size } \\
& \text { curve, and } \\
\psi_{50}= & \text { Impaction parameter for the jet at the } 50 \% \text { efficiency point. }
\end{aligned}
$$

Equation (B-2) was used to determine $d_{50}$ values at flow conditions different from those used to calibrate the impactor; it can also be used to relate the $d_{50}$ to the value under calibration conditions. If $C$ is assumed to be constant, then $d_{50}$ can be expressed as: 


$$
d_{50}=\left(d_{50}\right)_{\text {ref }}\left(\frac{\mu}{\mu_{\text {ref }}} \cdot \frac{Q_{\text {ref }}}{Q}\right)^{0.5}
$$

Where:

$$
\begin{aligned}
d_{50}= & \text { Aerodynamic diameter at sampling conditions, } \\
\mu= & \text { Viscosity of gas at sampling conditions, } \\
Q= & \text { Gas flow rate at sampling conditions, and } \\
\text { ref }= & \text { Subscript indicating value of parameter under calibration } \\
& \text { or reference conditions. }
\end{aligned}
$$

Cascade impactors of two designs were used for particle size analysis. Photographs of the impactors are presented in the body of the report.

Stage cut-size diameters used to interpret data obtained from the circular jet impactor (Andersen* Mark III High Temperature Sampler) are listed in Table B-1.

\section{TABLE B-1}

\section{STAGE CUT DIAMETERS FOR CIRCULAR JET IMPACTOR}

USED IN TESTS AB1 AND AB2

\section{Stage Number}

0

1

2

3

4

5

6 .

7

0

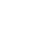

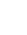

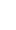

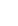

5

(a)

\begin{tabular}{l}
$(\mu \mathrm{m})$ \\
\hline 13.2 \\
8.3 \\
5.64 \\
3.8 \\
2.45 \\
1.25 \\
0.77 \\
0.52
\end{tabular}


The cut diameters listed in Table $B-1$ are those recommended by the manufacturer. ( $B-1)$ These values are in good agreement with calibrations reported by Cushing et al. $(B-2)$

Stage cut-off diameters for the rectangular jet impactor (Sierra Instrument Co., Model 226 Stack Sampler*) are listed in Table B-2, and the data were obtained from the work of Cushing et al. (B-2)

TABLE B-2

STAGE CUT DIAMETERS FOR RECTANGULAR JET IMPACTOR USED IN TESTS AB1 AND AB2

\section{Stage Number}

1

2

3

4

5

6

$\mathrm{d}_{50}(\mathrm{a})$

18.0

11.0

4.4

2.65

1.70

0.95

(a) Size of unit density spheres that are removed with $50 \%$ efficiency at $28^{\circ} \mathrm{C}$, $29.5 \mathrm{in.} \mathrm{Hg}$ pressure, and 0.25 ACFM.

The cut diameters 1 isted in Tables $B-1$ and $B-2$ were adjusted for sampling conditions using equation ( $B-3)$.

Particle size distributionș were constructed from cascade impactor data using the cut-off diameter approach described by Mercer. (B-3) An example calculation will be shown to illustrate the method.

*Manufactured by Sierra Instrument Co., Carmel Valley, CA. 
The stage accumulations of sodium were obtained by washing each stage collection paper with water and analyzing the water by flame emission spectrometry. Losses to the impactor walls were ignored.

TABLE B-3

EXAMPLE TREATMENT OF CASCADE IMPACTOR DATA $(a)$

\begin{tabular}{|c|c|c|c|c|c|}
\hline $\begin{array}{r}\text { Stage } \\
\text { Number }\end{array}$ & $\begin{array}{c}\text { Sodium } \\
\text { (mg) }\end{array}$ & $\begin{array}{c}\text { Mass } \\
\text { Fraction } \\
\end{array}$ & $\begin{array}{l}\text { Cumulative } \\
\text { Fraction }\end{array}$ & $\begin{array}{l}\text { One Minus } \\
\text { Cumulative } \\
\text { Fraction }\end{array}$ & $d_{50}$ \\
\hline 0 & 0.35 & 0.0605 & 0.0605 & 0.9395 & 20.6 \\
\hline 1 & 0.35 & 0.0605 & 0.1210 & 0.8190 & 13.0 \\
\hline 2 & 1.03 & 0.1779 & 0.2989 & 0.7011 & 8.82 \\
\hline 3 & 1.01 & 0.1744 & 0.4733 & 0.5267 & 5.94 \\
\hline 4 & 1.20 & 0.2073 & 0.6806 & 0.3194 & 3.83 \\
\hline 5 & 0.91 & 0.1572 & 0.8378 & 0.1622 & 1.96 \\
\hline 6 & 0.54 & 0.0933 & 0.9311 & 0.0689 & 1.20 \\
\hline 7 & 0.25 & 0.0432 & 0.9743 & 0.0257 & 0.81 \\
\hline \multirow[t]{2}{*}{8} & 0.15 & 0.0259 & 1.0 & 0 & \\
\hline & 5.79 & & & & \\
\hline
\end{tabular}

(a) Sample Number: AB1, T4I1, taken $1140 \mathrm{~s}$ after Na spill.

Impactor: Circular jet.

Flow Rate: 0.105 liter/s

Temperature: $57^{\circ} \mathrm{C}$

Pressure: $0.137 \mathrm{MPa}$.

(b) Net mass after correction for stage paper blank.

The particle size distribution was obtained by plotting the two righthand columns in Table B-3 on log-probability paper as shown in Figure B-1. The mass median diameter and geometric standard deviation can be obtained from the line drawn through the data points. The geometric standard deviation was obtained from: 


$$
\sigma_{g}=\frac{\text { Particle Diameter at } 84.16 \%}{\text { Particle Diameter at } 50 \%}
$$

Particle size distributions for a11 other samples obtained in Tests $A B 1$ and $A B 2$ are presented in the graphs that follow.

Most sample data fit a log-normal distribution reasonably well; however, a few were obviously bi-modal (e.g., Figure B-11). For the purpose of correlating these with the rest of the data, a log-normal distribution was assumed. 


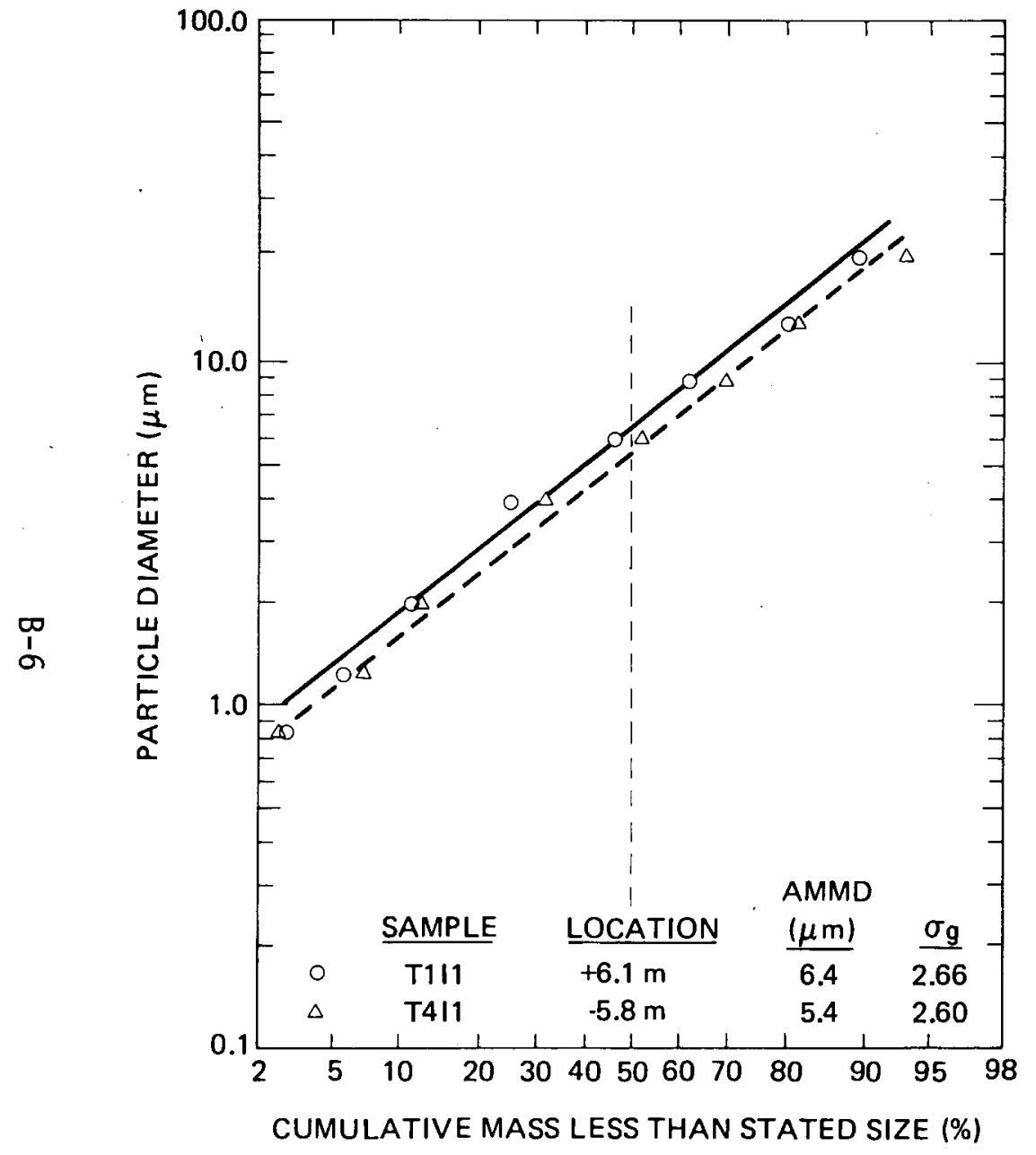

FIGURE B-1. Circular Jet Impactor Sample Withdrawn $1140 \mathrm{~s}$ After Start of $\mathrm{Na}$ Spill in Test AB1.

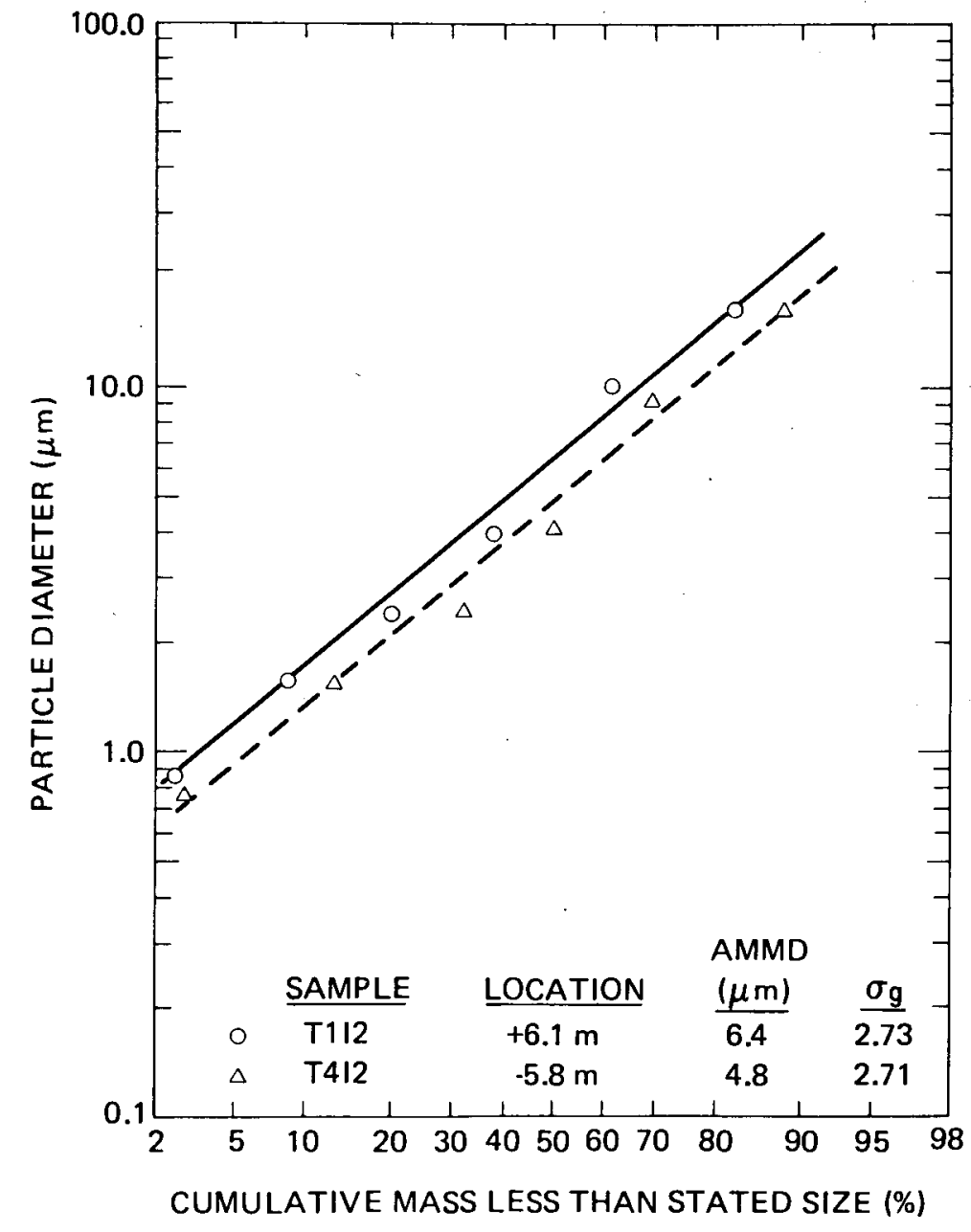

FIGURE B-2. Rectangular Jet Impactor Sample Withdrawn $1800 \mathrm{~s}$ After Start of $\mathrm{Na} \mathrm{Spill} \mathrm{in} \mathrm{Test} \mathrm{ABT.}$ 


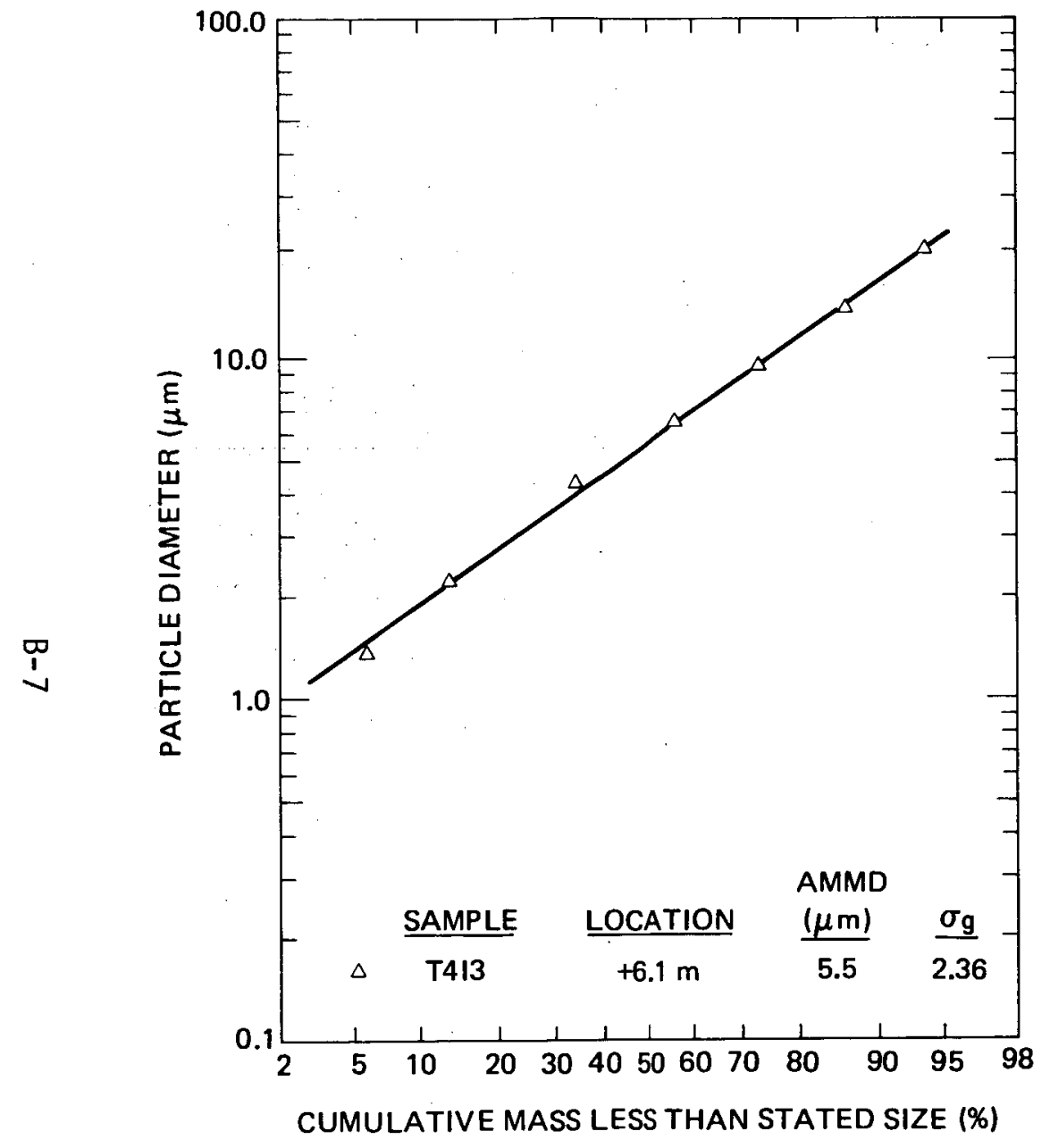

FIGURE B-3. Circular Jet Impactor Sample Withdrawn $4200 \mathrm{~s}$ After Start of $\mathrm{Na}$ Spill in Test ABI.

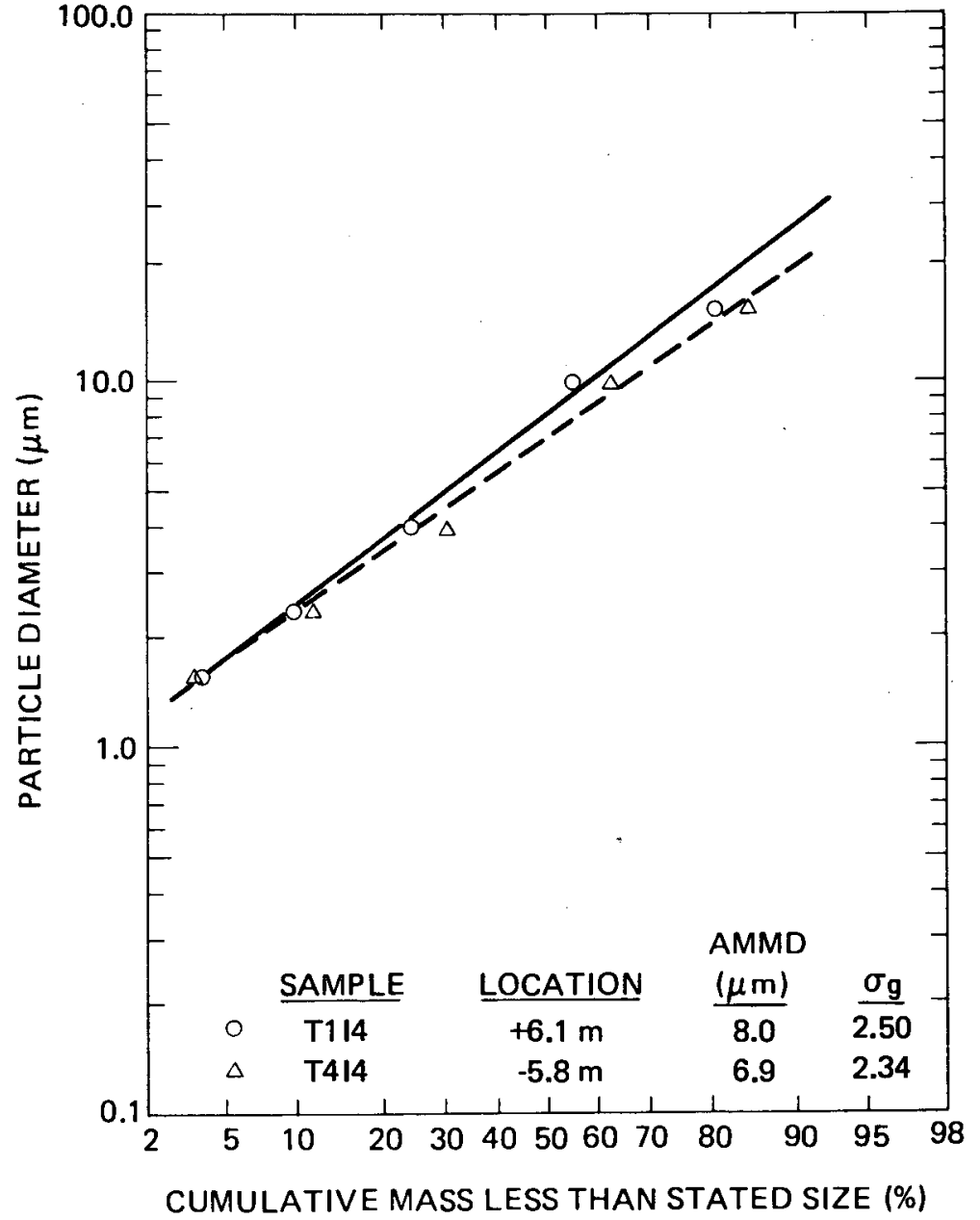

FIGURE B-4. Rectangular Jet Impactor Sample Withdrawn $6300 \mathrm{~s}$ After Start of $\mathrm{Na}$ Spill in Test ABI. 


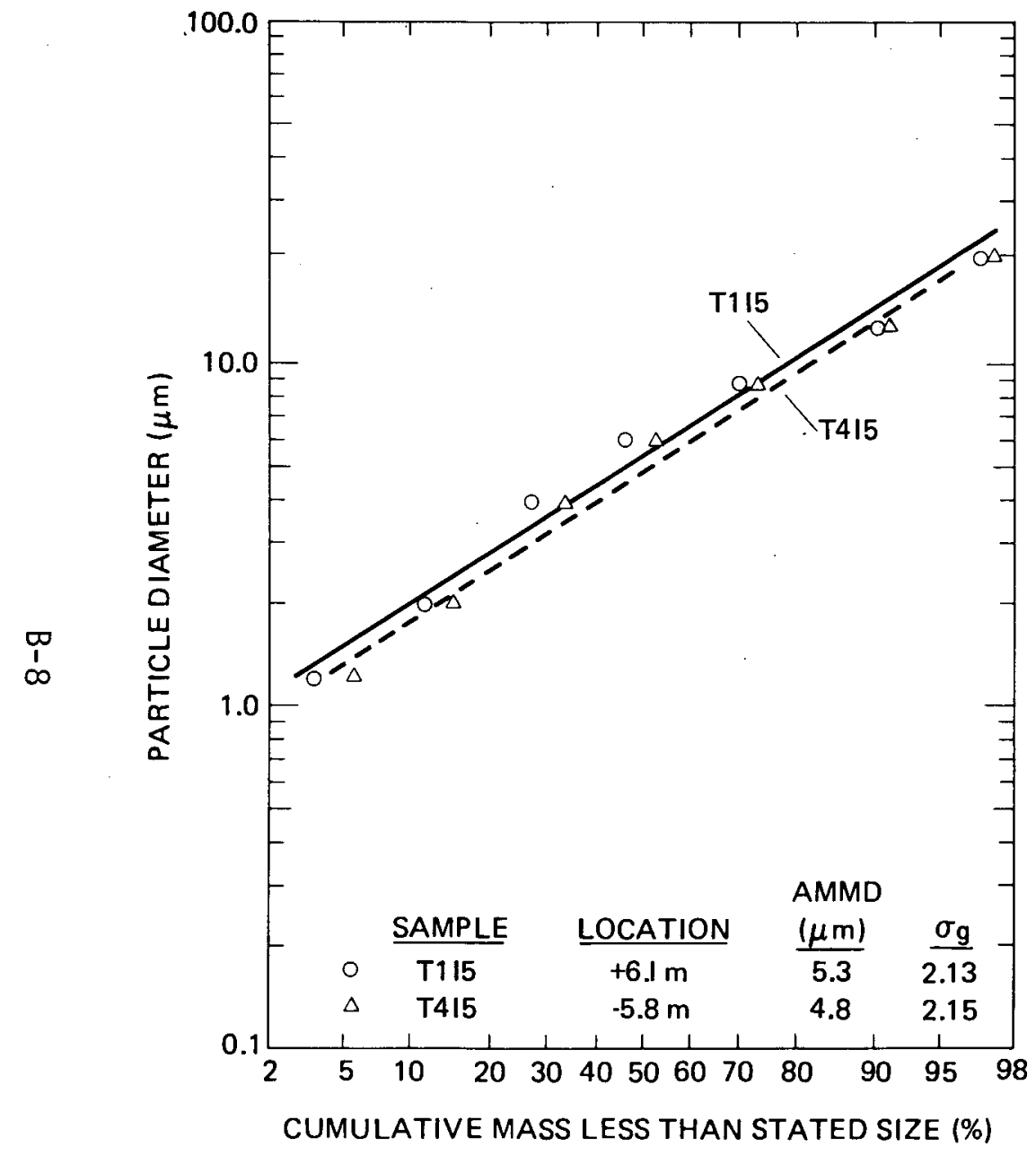

FIGURE B-5. Circular Jet Impactor Sample Withdrawn $1.14 \times 10^{4} \mathrm{~s}$ After Start of $\mathrm{Na}$ Spill in Test ABl.

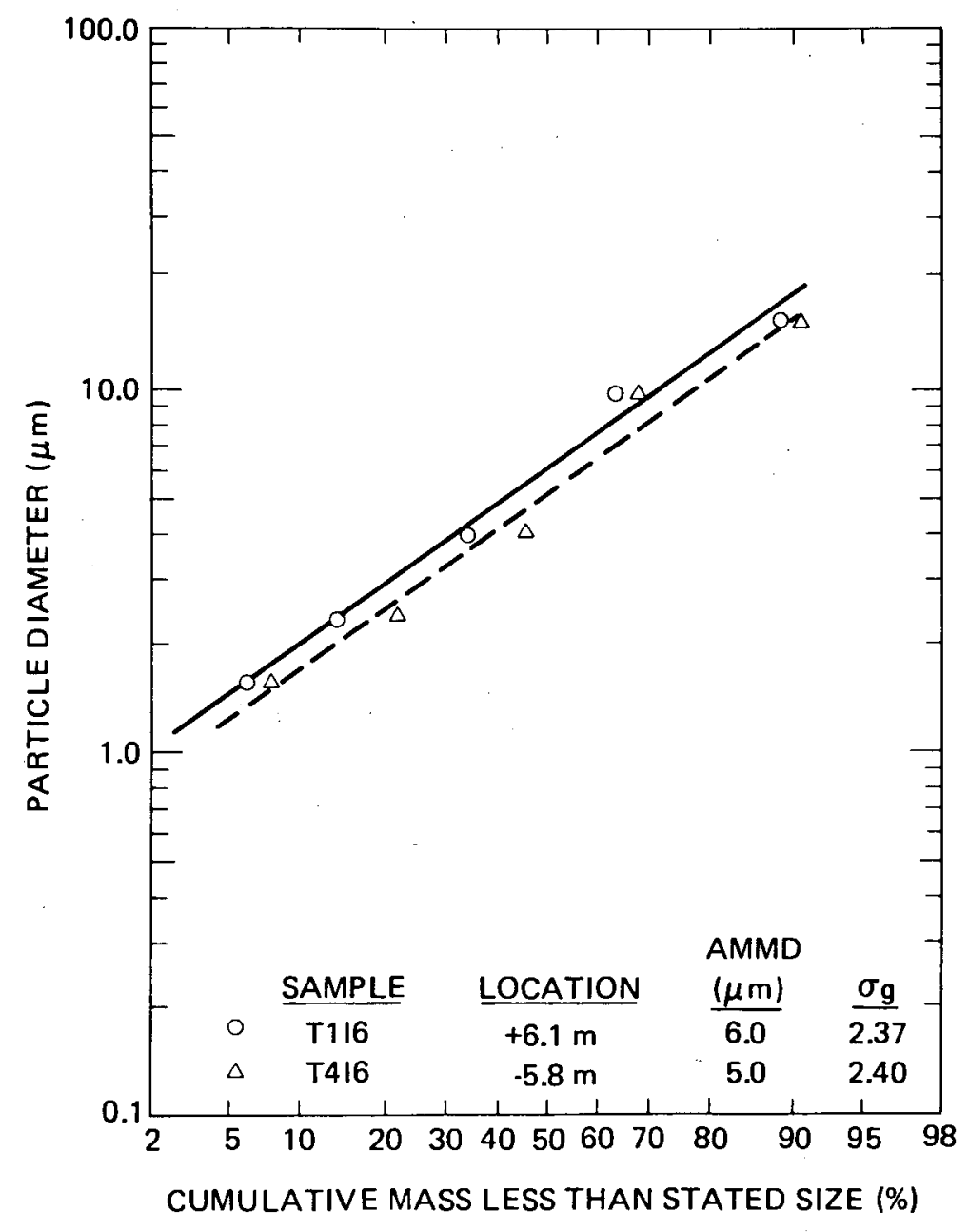

FIGURE B-6. Rectangular Jet Impactor Sample Withdrawn $1.2 \times 10^{4} \mathrm{~s}$ After Start of $\mathrm{Na}$ Spill in Test $A B 1$. 


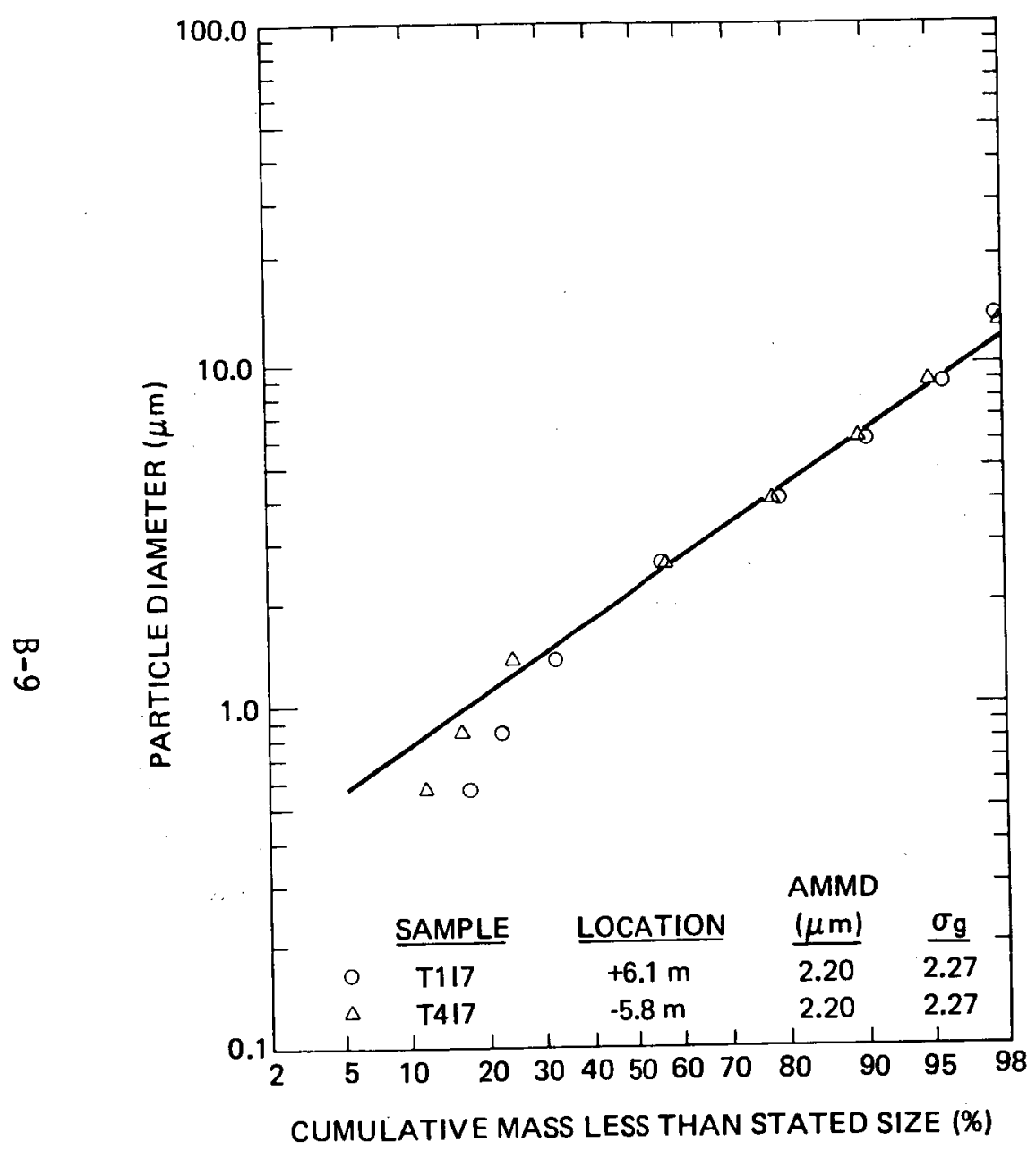

FIGURE B-7. Circular Jet Impactor Sample Withdrawn $3.84 \times 10^{4} \mathrm{~s}$ After Start of Na Spi11 in Test ABT.

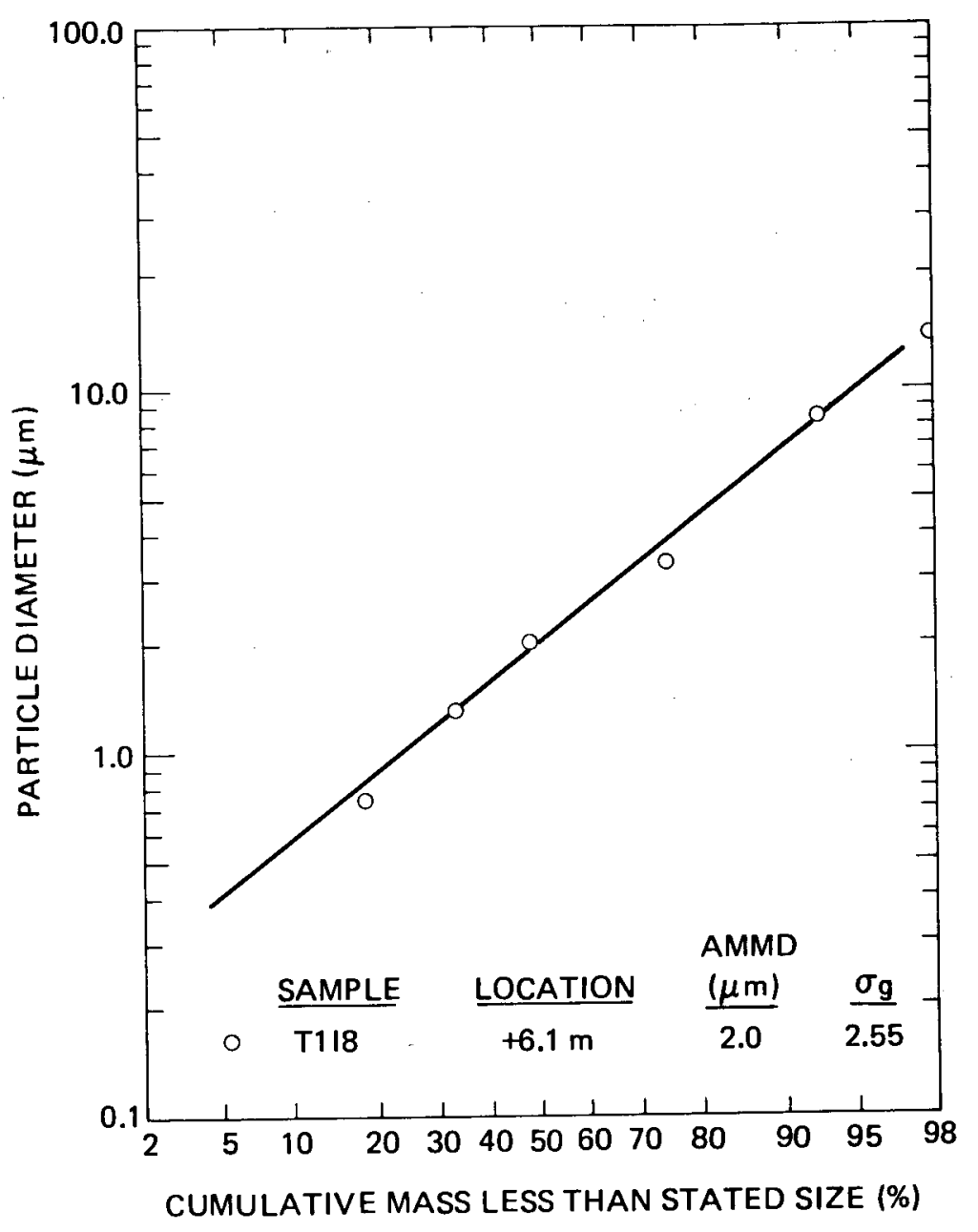

FIGURE B-8. Rectangular Jet Impactor Sample Withdrawn $3.99 \times 10^{4} \mathrm{~s}$ After Start of $\mathrm{Na}$ Spill in Test ABI. 


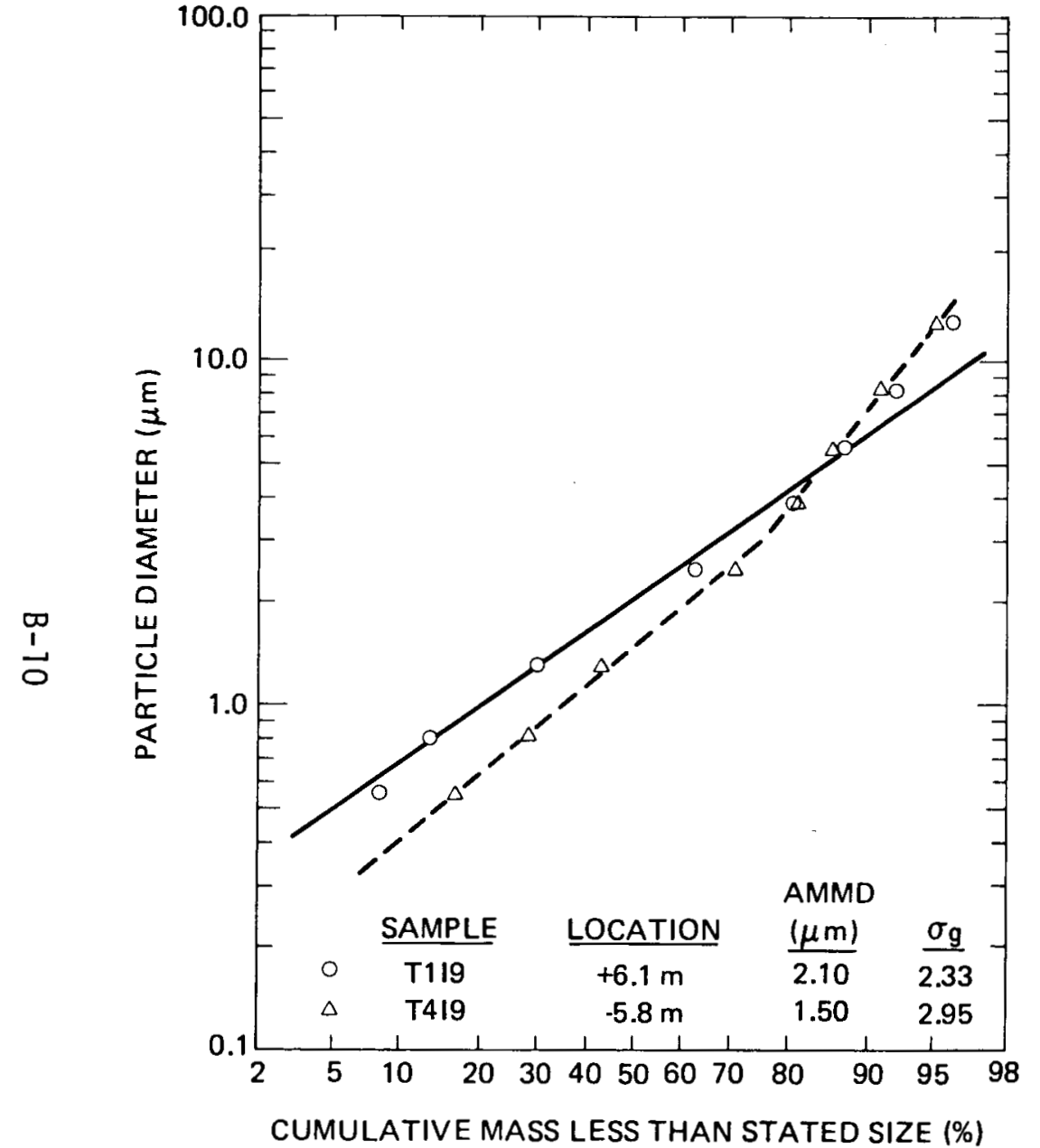

FIGURE B-9. Circular Jet Impactor Sample Withdrawn $9.24 \times 10^{4} \mathrm{~s}$ After Start of Na Spill in Test ABI.

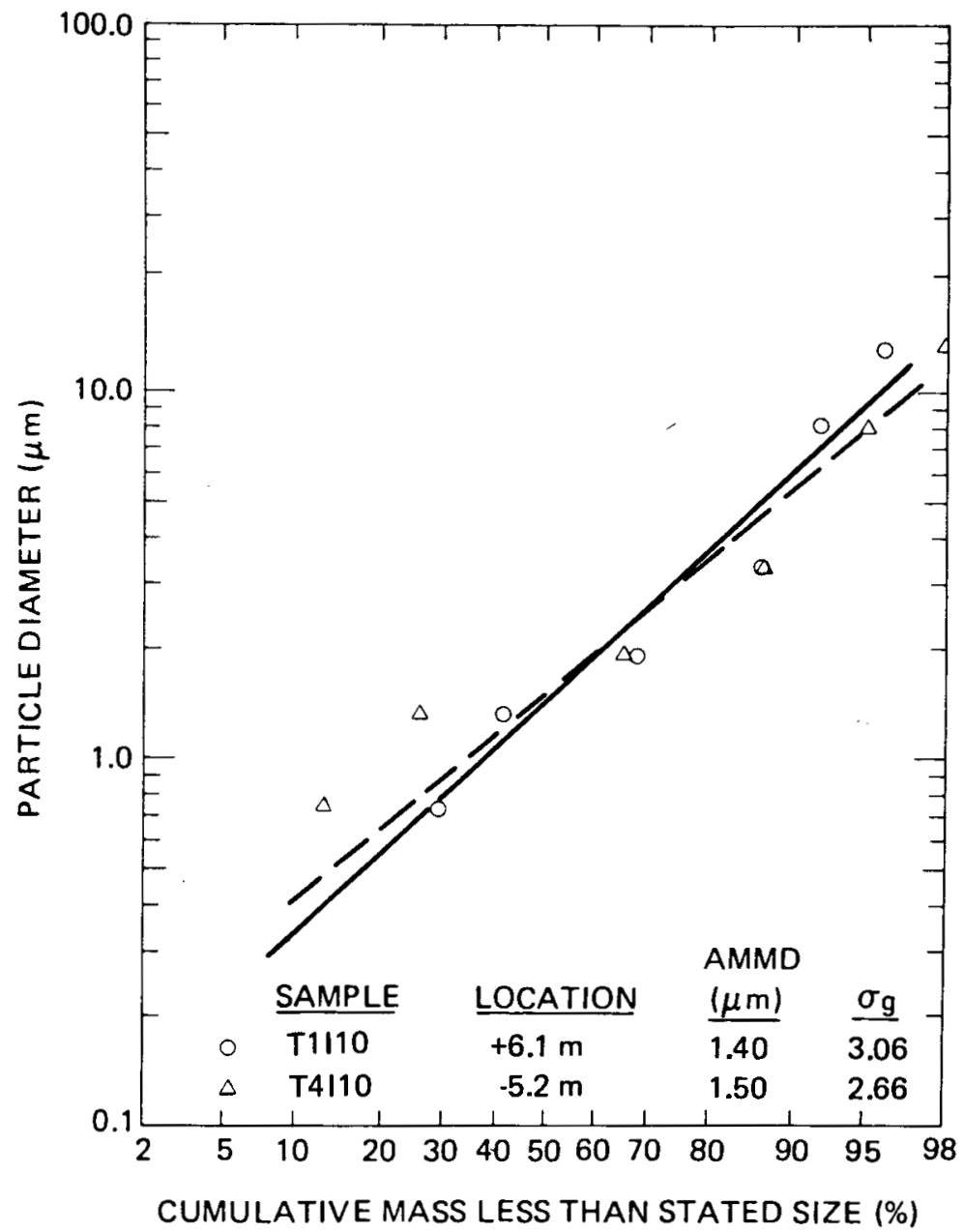

FIGURE B-10. Rectangular Jet Impactor Sample Withdrawn $9.81 \times 10^{4} \mathrm{~s}$ After Start of Na Spil1 in Test ABT. 

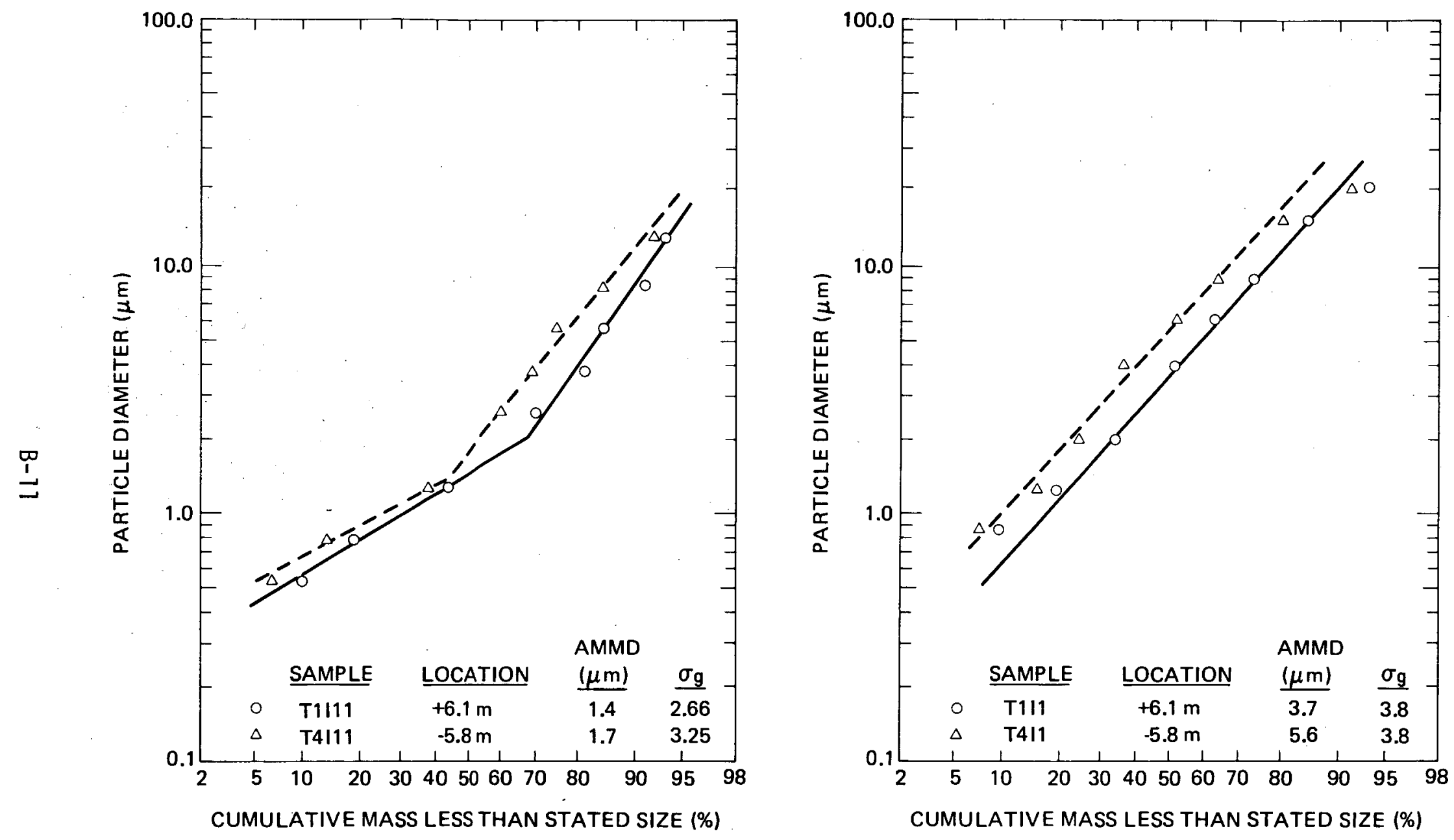

FIGURE B-11. Circular Jet Impactor Sample Withdrawn $1.76 \times 10^{5} \mathrm{~s}$ After Start of $\mathrm{Na}$ Spill in Test ABT.

FIGURE B-12. Circular Jet Impactor Sample Withdrawn $1080 \mathrm{~s}$ After Start of $\mathrm{Na}$ Spill in Test AB2. 


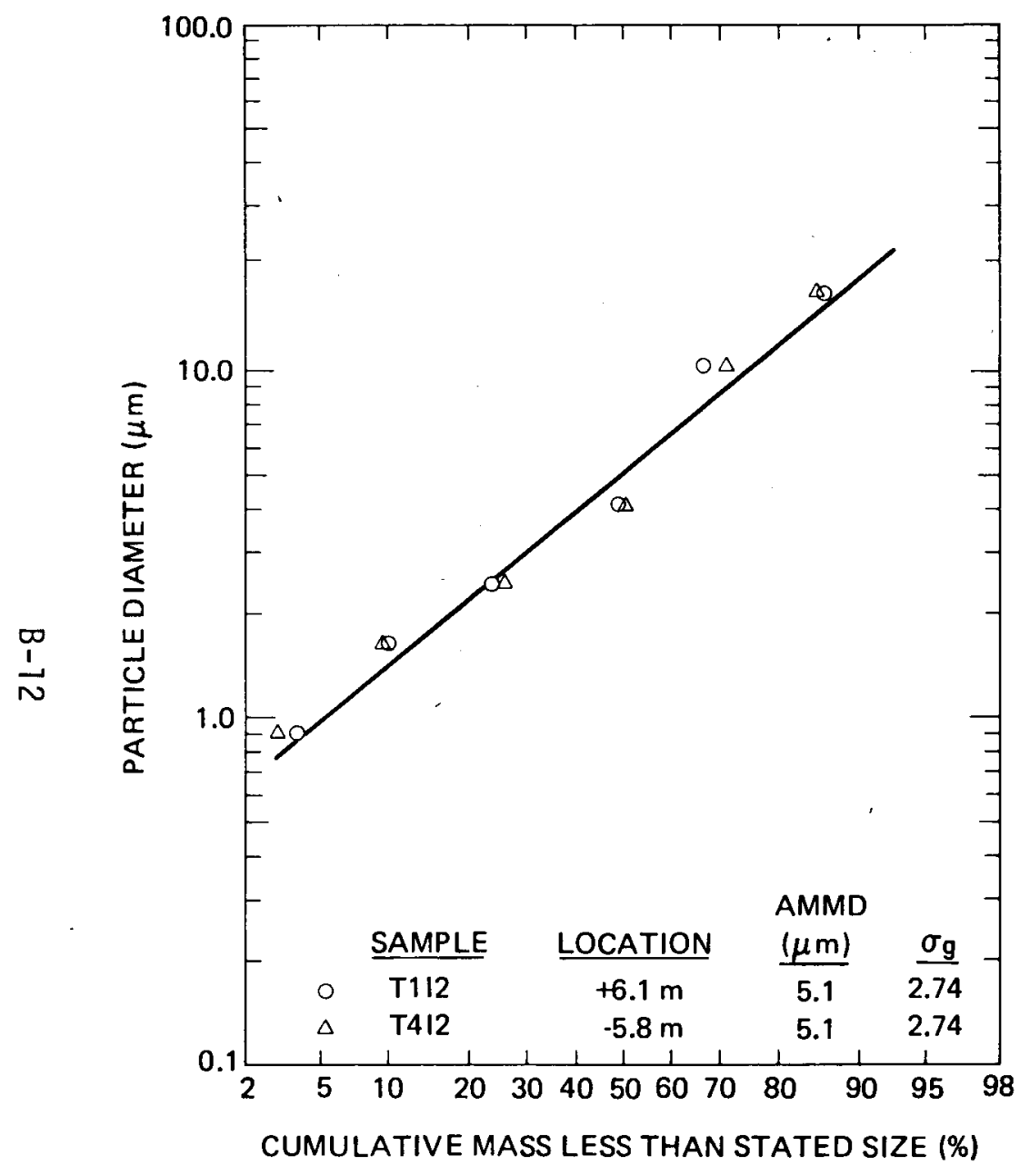

FIGURE B-13. Rectangular Jet Impactor Sample Withdrawn 1620 s After Start of Na Spill in Test AB2.

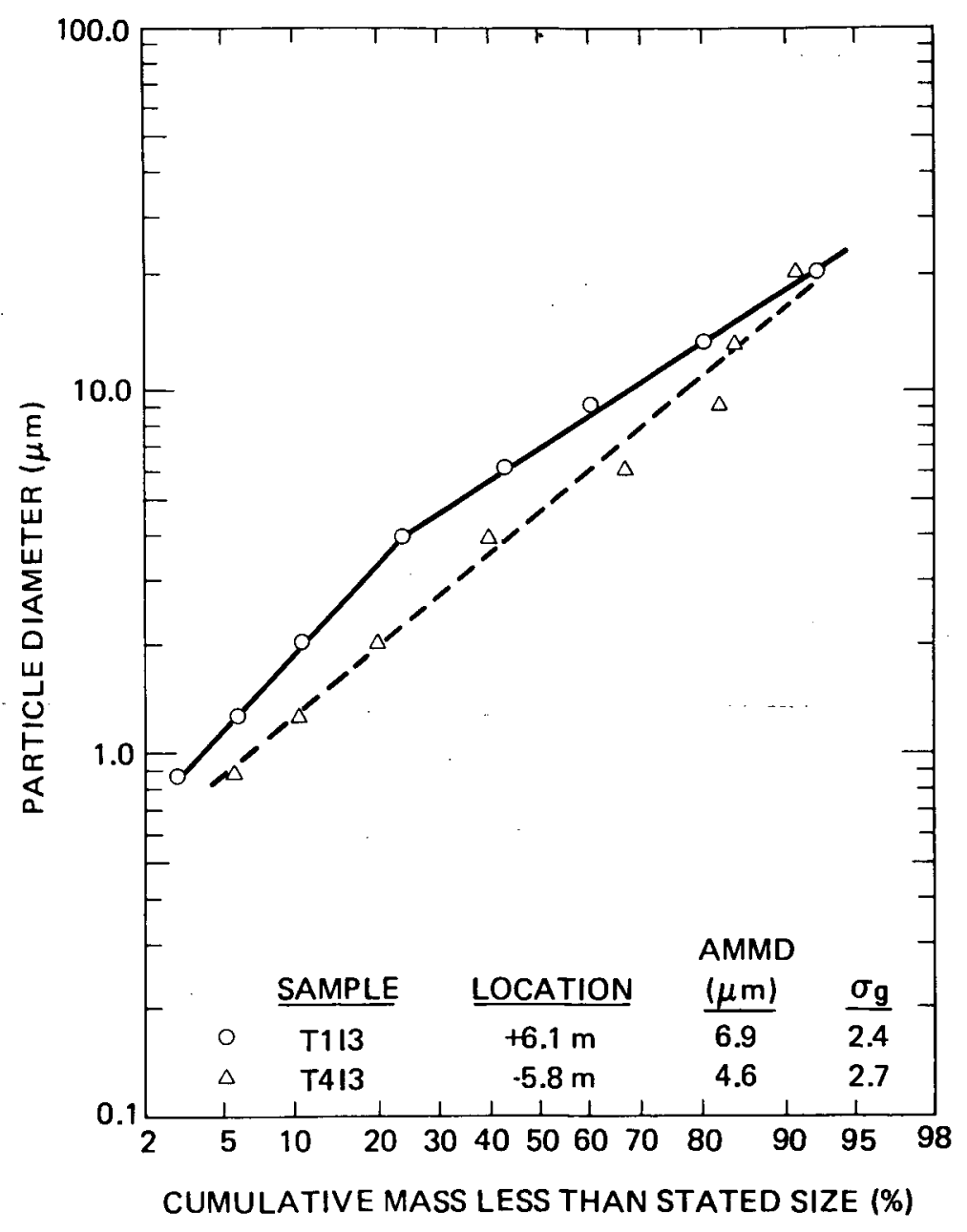

FIGURE B-14. Circular Jet Impactor Sample Withdrawn $4200 \mathrm{~s}$ After Start of $\mathrm{Na}$ Spill in Test AB2. 


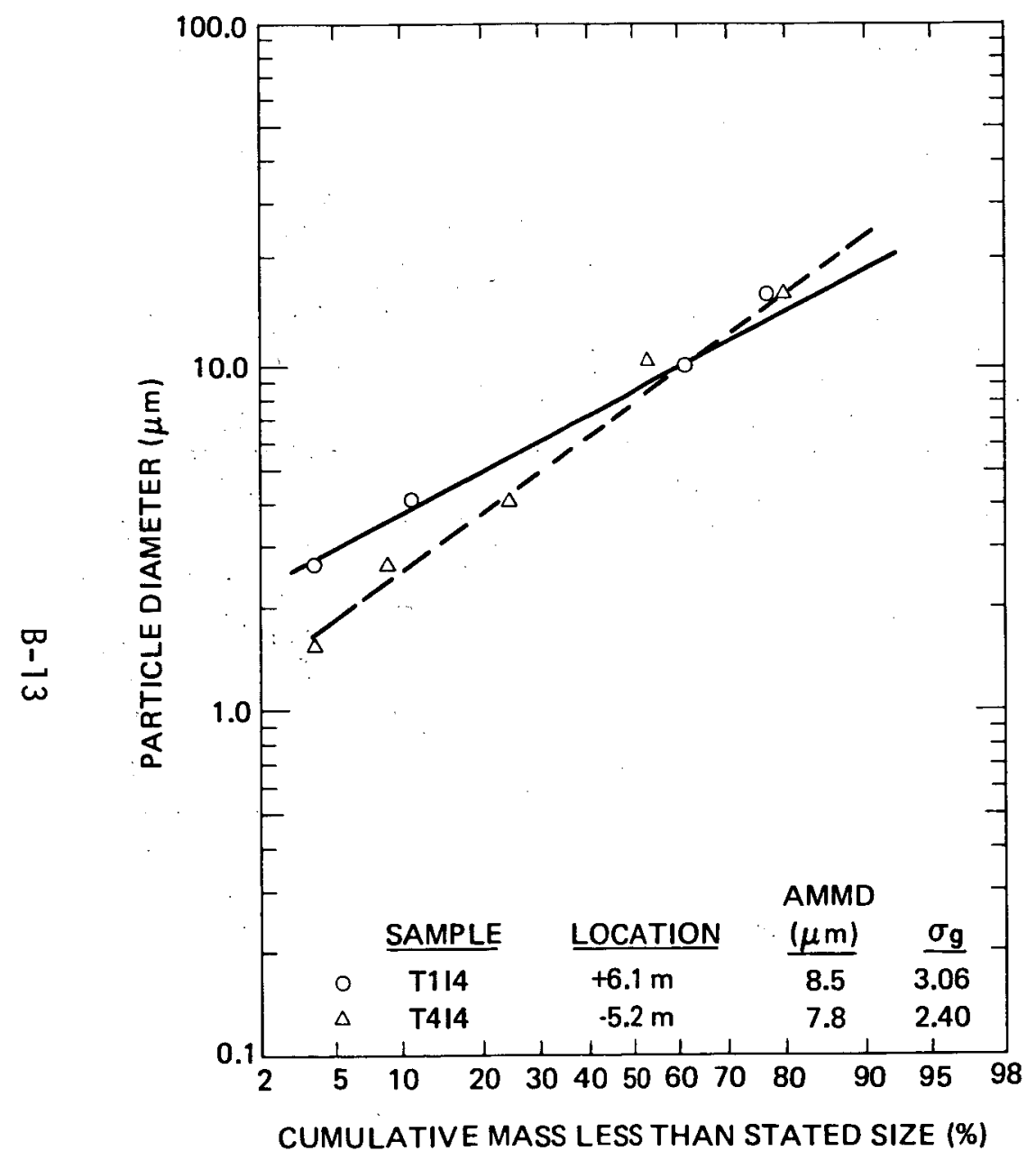

FIGURE B-15. Rectangular Jet Impactor Sample Withdrawn $5400 \mathrm{~s}$ After Start of $\mathrm{Na}$ Spil1 in Test AB2.

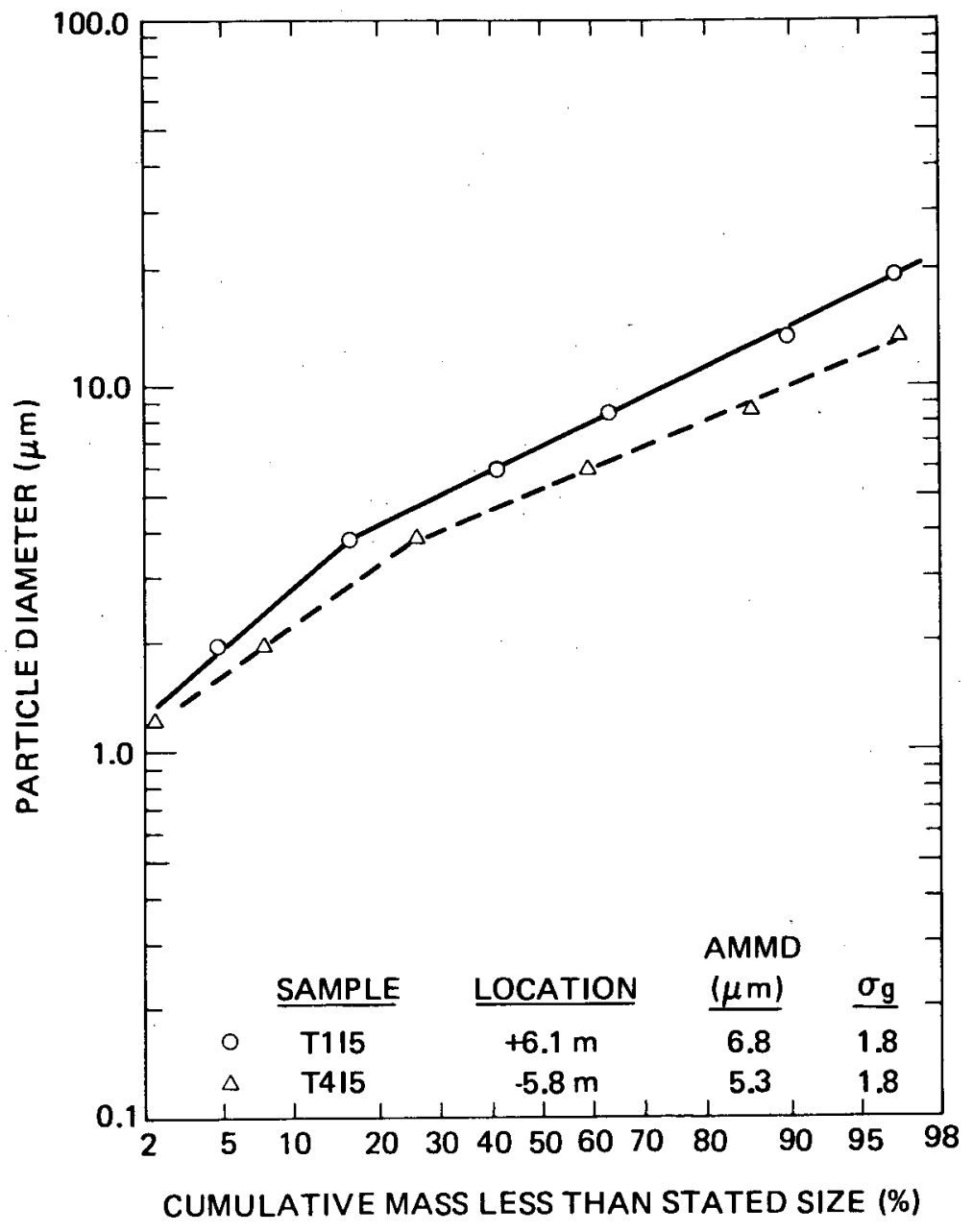

FIGURE B-16. Circular Jet Impactor Sample Withdrawn $1.14 \times 10^{4} \mathrm{~s}$ After Start of $\mathrm{Na}$ Spill in Test AB2. 


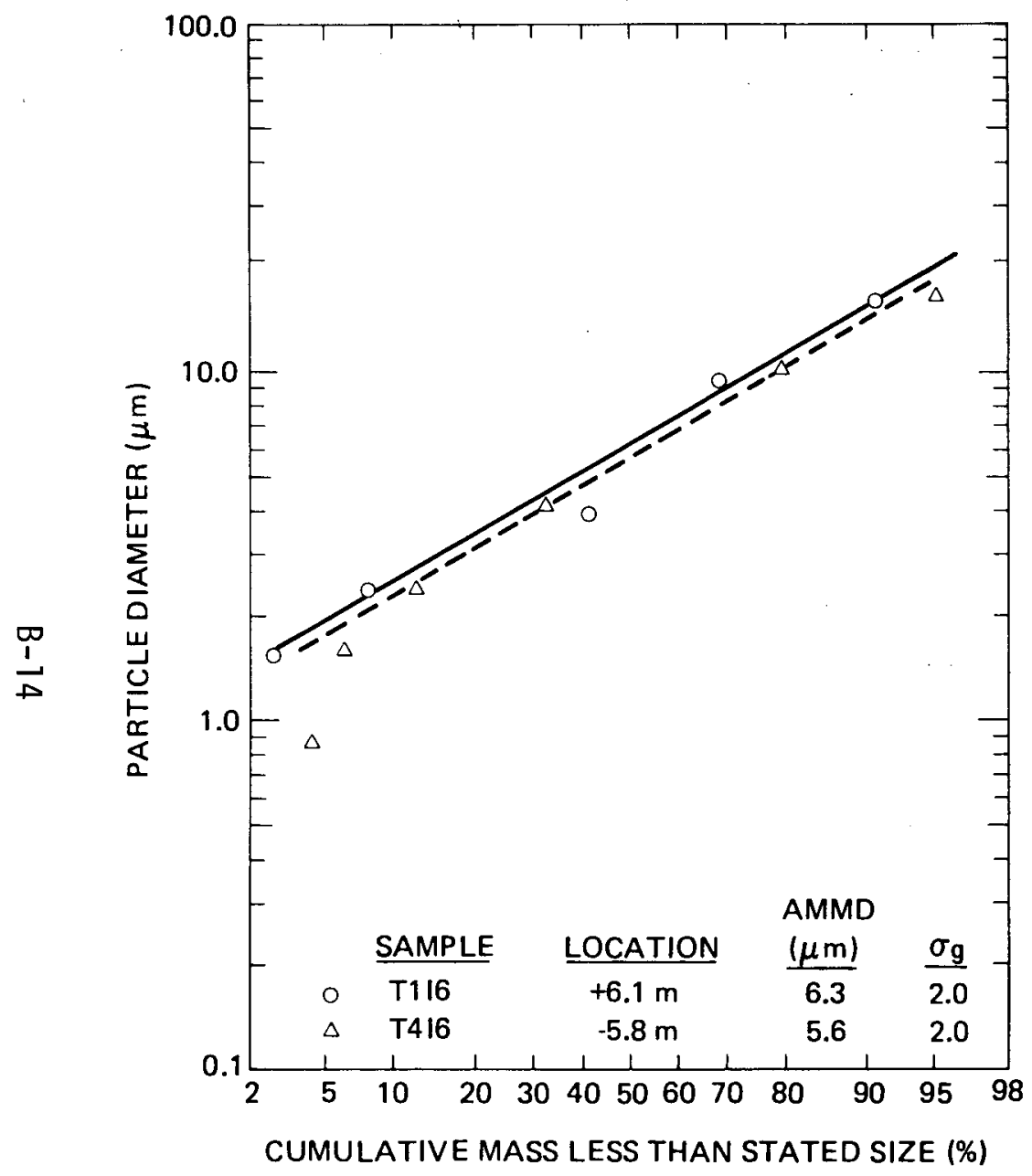

FIGURE B-17. Rectangular Jet Impactor Sample Withdrawn $1.19 \times 10^{4} \mathrm{~s}$ After Start of $\mathrm{Na}$ Spill in Test AB2.

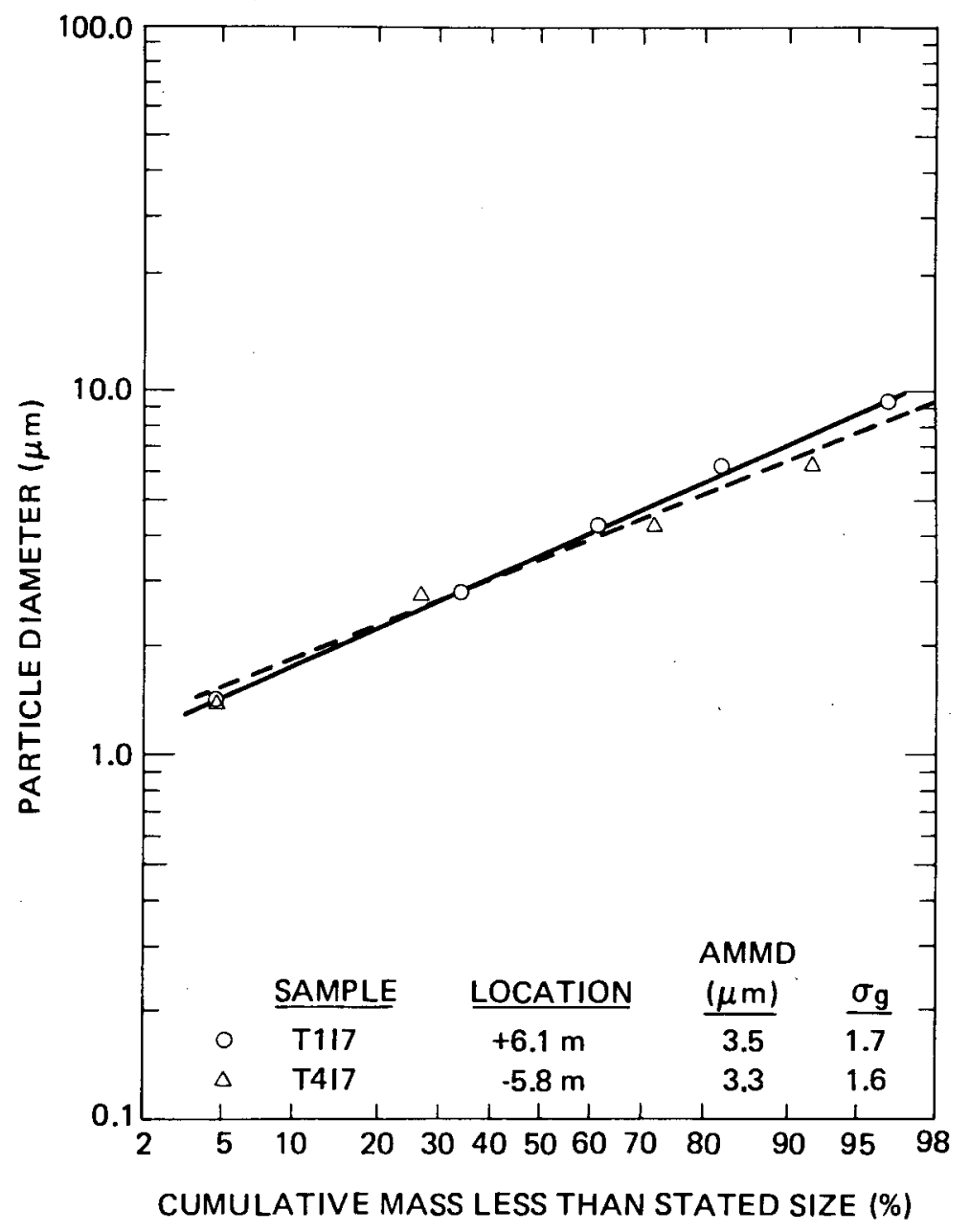

FIGURE B-18. Circular Jet Impactor Sample Withdrawn $3.93 \times 10^{4} \mathrm{~s}$ After Start of $\mathrm{Na} S p i l 1$ in Test AB2. 


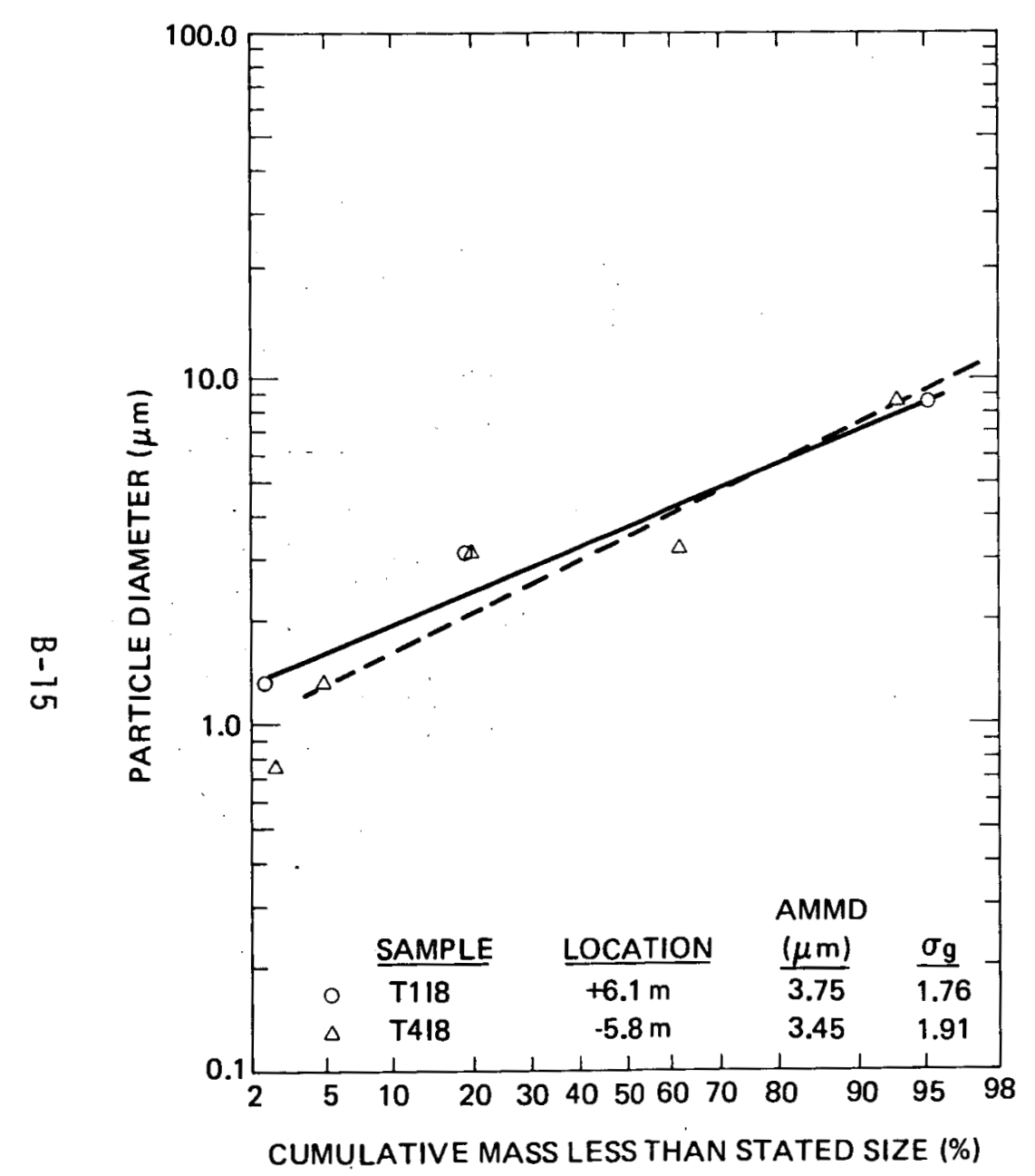

FIGURE B-19. Rectangular Jet Impactor Sample Withdrawn $4.14 \times 10^{4} \mathrm{~s}$ After Start of Na Spi11 in Test AB2.

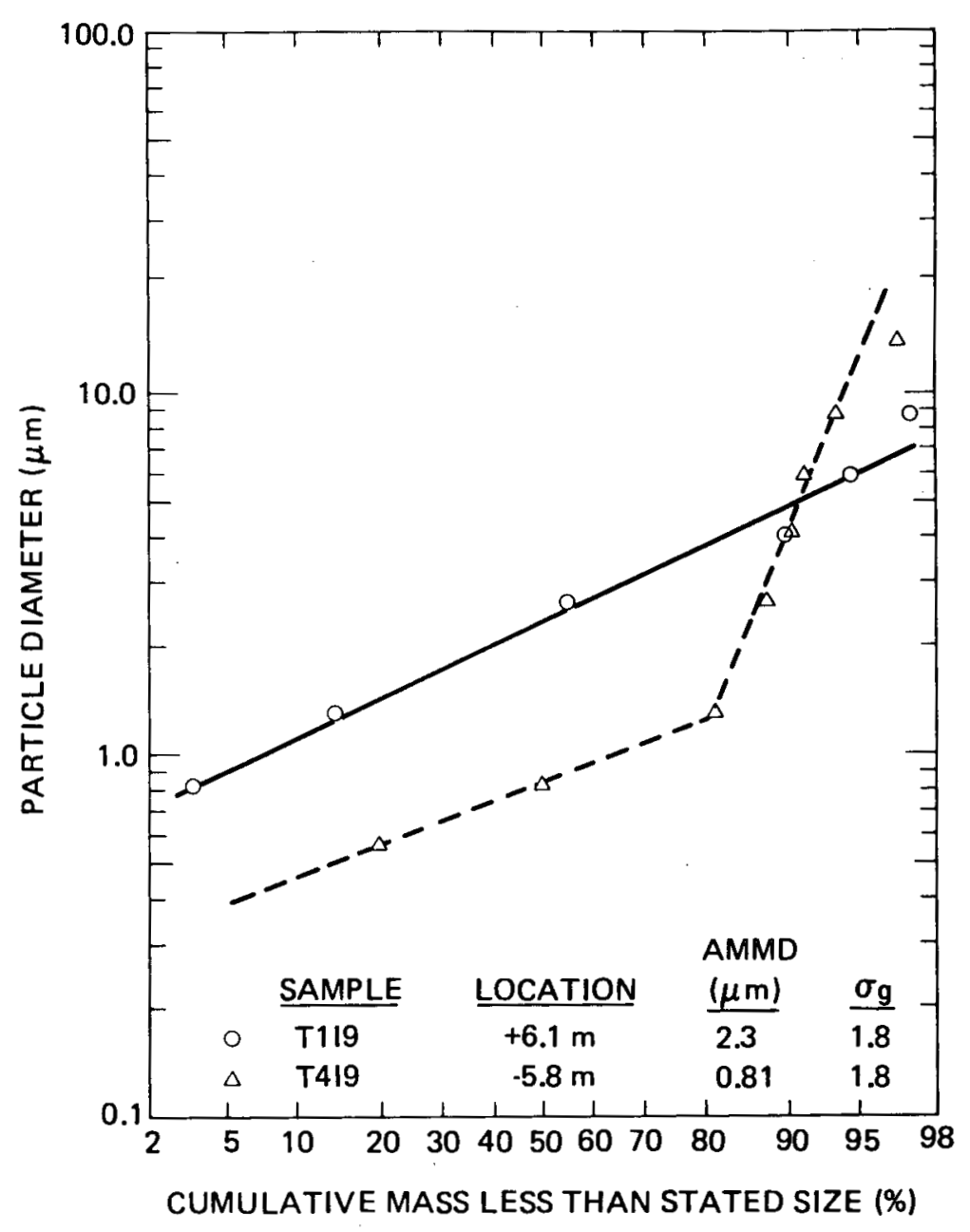

FIGURE B-20. Circular Jet Impactor Sample Withdrawn $8.82 \times 10^{4} \mathrm{~s}$ After Start of $\mathrm{Na} \mathrm{Spill} \mathrm{in} \mathrm{Test} \mathrm{AB2.}$ 


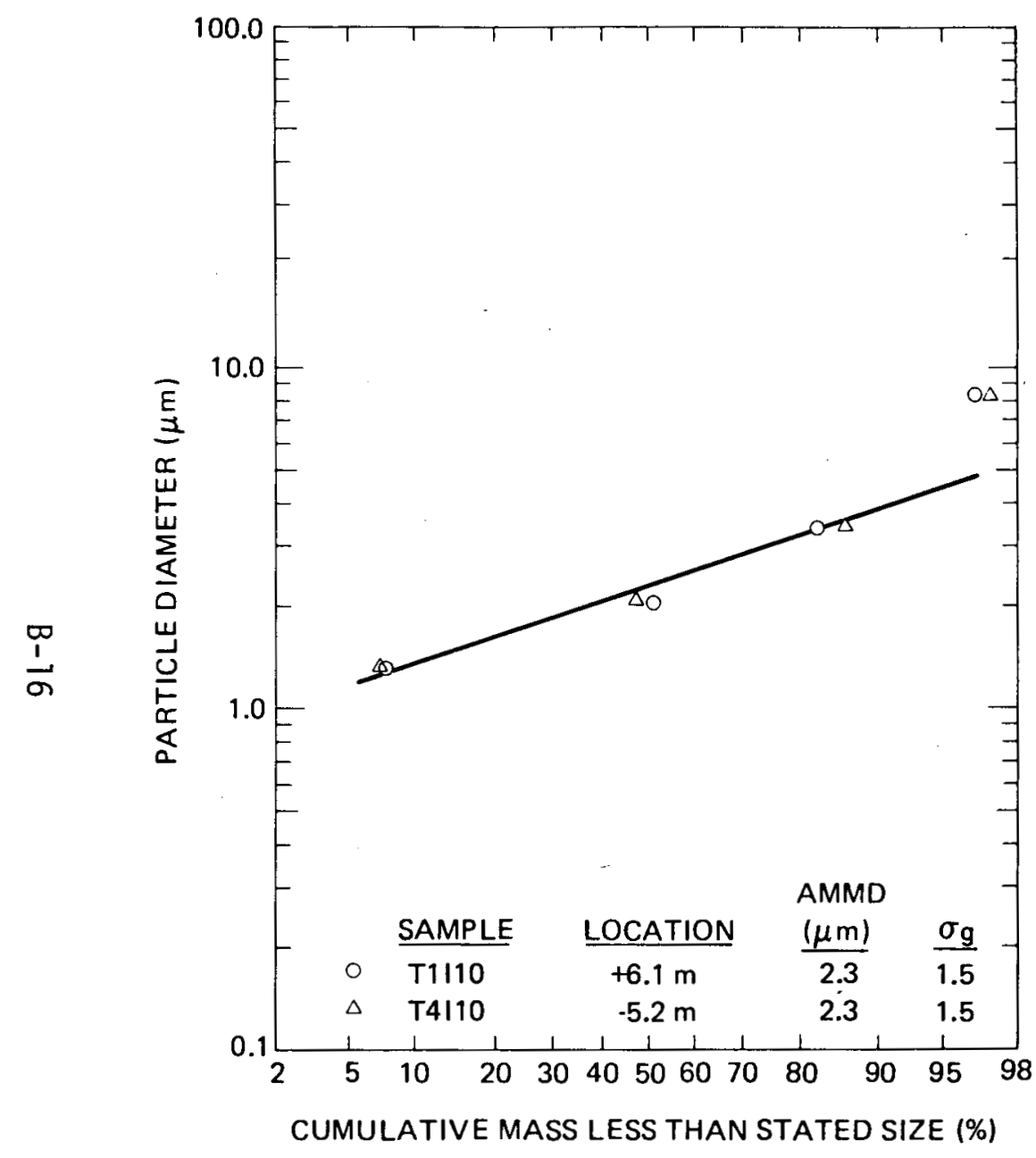

FIGURE B-21. Rectangular Jet Impactor Sample Withdrawn $9.27 \times 10^{4} \mathrm{~s}$ After Start of $\mathrm{Na}$ Spill in Test AB2.

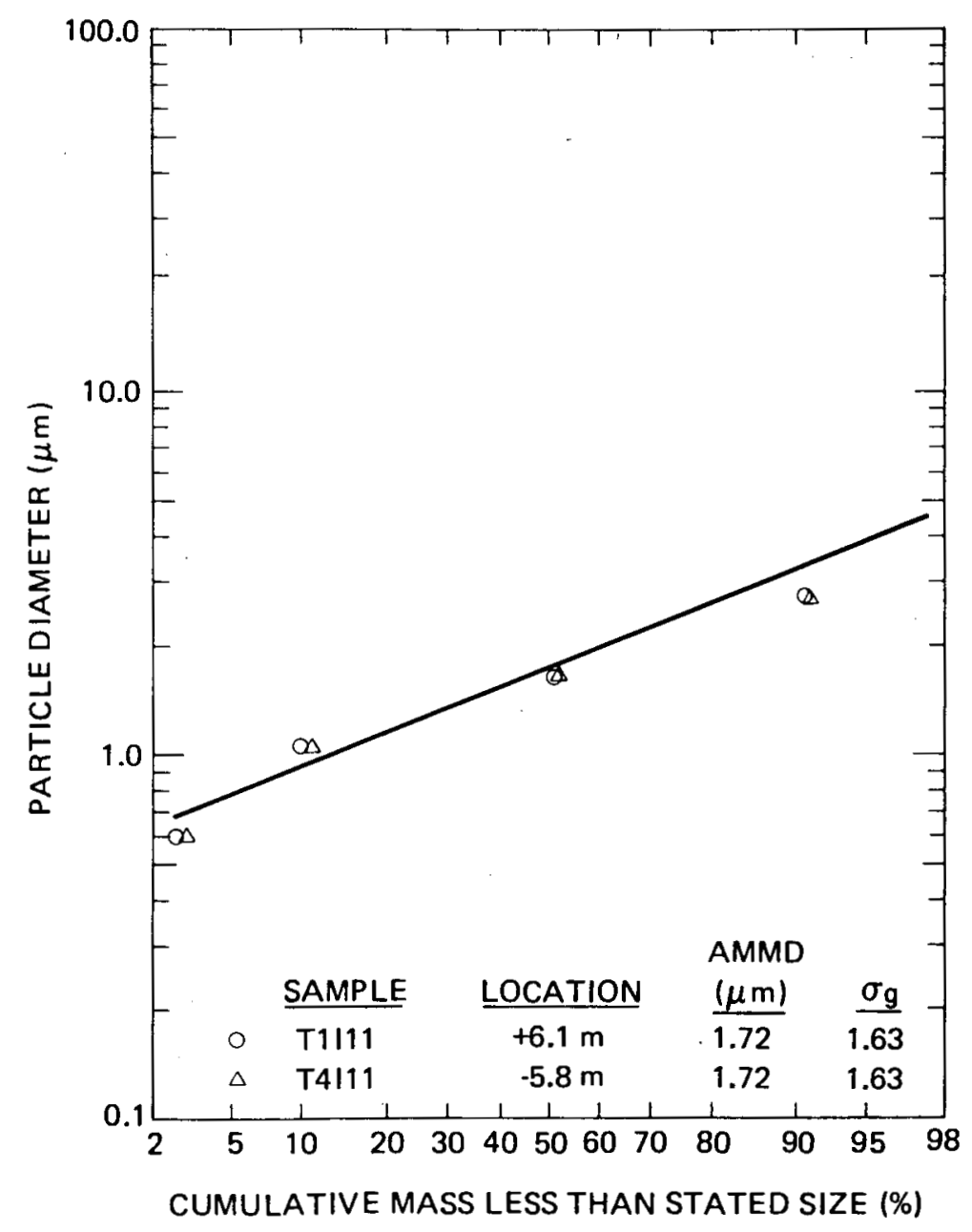

FIGURE B-22. Rectangular Jet Impactor Sample Withdrawn $1.90 \times 10^{5} \mathrm{~s}$ After Start of $\mathrm{Na}$ Spill in Test AB2. 


\section{REFERENCES}

B-1. "Operating Manual for Andersen 2000, Inc., Mark II and Mark III Particle Sizing Stack Samplers," Report TR \#76-900023, Andersen 2000, Inc., Atlanta, GA, January 1, 1976.

B-2. K. M. Cushing et al. "Particulate Sizing Techniques for Control Device Evaluation: Cascade Impactor Calibrations," Report EPA-600/2-76-280, Southern Research Institute, Birmingham, AL, October 1976.

B-3. T. T. Mercer, "The Interpretation of Cascade Impactor Data," Indus. Hygiene J., 26, 1965, pp. 236-241. 
APPENDIX C 
In this appendix, data obtained from the deposition coupons are tabulated. Results from Test $A B 1$ are presented in Table $C-1$, and results from Test $A B 2$ are listed in Table $\mathrm{C}-2$. The sample numbers identify the sampling location (refer to Table 2 in the text) and the time sequence (number following the letter D).

Data presented in Tables $\mathrm{C}-1$ and $\mathrm{C}-2$ represent $\mathrm{a} 11$ of the coupon results in which the sodium collected was significantly above background contamination levels. One of the limitations of the coupon sampling procedure is the relatively small mass collection rate--except at high mass concentrations where large particles are present. 
TABLE C- 1

DEPOSITION COUPON DATA FROM TEST ABI

\begin{tabular}{|c|c|c|c|c|c|c|}
\hline $\begin{array}{l}\text { Sample } \\
\text { Number }\end{array}$ & $\begin{array}{c}\text { Run Time } \\
(\mathrm{s})\end{array}$ & $\begin{array}{c}\text { Exposure } \\
\text { Time } \\
(\mathrm{s}) \\
\end{array}$ & $\begin{array}{c}\text { Mass of } \mathrm{Na} \\
(\mathrm{mg}) \\
\end{array}$ & $\begin{array}{c}\text { Airborne } \mathrm{Na} \\
\left(\mathrm{g} / \mathrm{m}^{3}\right)\end{array}$ & $\begin{array}{c}\text { Deposition } \\
\text { Velocity } \\
(\mathrm{cm} / \mathrm{s}) \\
\end{array}$ & $\begin{array}{c}\text { Particle } \\
\text { Diameter } \\
\text { (um) }\end{array}$ \\
\hline $\begin{array}{l}\text { T3-D1 } \\
\text { T2-D1 }\end{array}$ & $\begin{array}{l}1.20(3)^{(b)} \\
1.20(3)^{(b)}\end{array}$ & $\begin{array}{l}120 \\
120\end{array}$ & $\begin{array}{l}19.4 \\
15.1\end{array}$ & $\begin{array}{l}1.25(1) \\
1.25(1)\end{array}$ & $\begin{array}{l}0.63 \\
0.49\end{array} \mid$ & 14.3 \\
\hline $\begin{array}{l}\text { TI-D1 } \\
\text { T3-D2 } \\
\text { T4-D1 } \\
\text { T2-D2 }\end{array}$ & $\begin{array}{l}2.10(3) \\
2.10(3) \\
2.10(3) \\
2.10(3)\end{array}$ & $\begin{array}{l}120 \\
120 \\
120 \\
120\end{array}$ & $\begin{array}{l}19.2 \\
40.2 \\
19.8 \\
25.3\end{array}$ & $\begin{array}{l}1.50(1) \\
1.50(1) \\
1.50(1) \\
1.50(1)\end{array}$ & $\begin{array}{l}0.52 \\
1.09 \\
0.54 \\
0.69\end{array}$ & $\begin{array}{r}16.2 \\
.\end{array}$ \\
\hline $\begin{array}{l}\text { T2-D3 } \\
\text { T4-D4 } \\
\text { T1-D2 }\end{array}$ & $\begin{array}{l}2.76(3) \\
2.76(3) \\
2.76(3)\end{array}$ & $\begin{array}{l}120 \\
120 \\
120\end{array}$ & $\begin{array}{l}38.3 \\
26.8 \\
28.1\end{array}$ & $\begin{array}{l}1.58(1) \\
1.58(1) \\
1.58(1)\end{array}$ & $\begin{array}{l}0.99 \\
0.69 \\
0.72\end{array}$ & 17.1 \\
\hline $\begin{array}{l}\text { T2-D4 } \\
\text { T4-D3 } \\
\text { T3-D3 } \\
\text { TI-D3 }\end{array}$ & $\begin{array}{l}3.96(3) \\
3.96(3) \\
3.96(3) \\
4.02(3)\end{array}$ & $\begin{array}{l}120 \\
120 \\
120 \\
120\end{array}$ & $\begin{array}{l}55.2 \\
32.3 \\
28.6 \\
14.6\end{array}$ & $\begin{array}{l}1.20(1) \\
1.20(1) \\
1.20(1) \\
1.10(1)\end{array}$ & $\begin{array}{l}1.87 \\
1.09 \\
1.06 \\
0.54\end{array}$ & 20.5 \\
\hline $\begin{array}{l}\text { T1-D4 } \\
\text { T4-D4 } \\
\text { T2-D5 } \\
\text { T3-D5 }\end{array}$ & $\begin{array}{l}5.79(3) \\
5.79(3) \\
5.79(3) \\
5.82(3)\end{array}$ & $\begin{array}{l}180 \\
180 \\
180 \\
240\end{array}$ & $\begin{array}{l}3.84 \\
4.95 \\
3.25 \\
4.60\end{array}$ & $\begin{array}{l}3.60(0) \\
3.60(0) \\
3.60(0) \\
3.60(0)\end{array}$ & $\begin{array}{l}0.29 \\
0.37 \\
0.24 \\
0.26\end{array}$ & 10.3 \\
\hline $\begin{array}{l}\text { T4-D5 } \\
\text { T2-D6 } \\
\text { T3-D5 } \\
\text { T1-D5 }\end{array}$ & $\begin{array}{l}7.59(3) \\
7.59(3) \\
7.65(3) \\
7.65(3)\end{array}$ & $\begin{array}{l}180 \\
180 \\
180 \\
180\end{array}$ & $\begin{array}{l}1.05 \\
1.09 \\
1.30 \\
0.62\end{array}$ & $\begin{array}{l}1.60(0) \\
1.60(0) \\
1.50(0) \\
1.50(0)\end{array}$ & $\begin{array}{l}0.18 \\
0.18 \\
0.23 \\
0.11\end{array}$ & 8.0 \\
\hline $\begin{array}{l}\text { T1-D6 } \\
\text { T3-D6 } \\
\text { T2-D7 }\end{array}$ & $\begin{array}{ll}9.51 & (3) \\
9.51 & (3) \\
9.54 & (3)\end{array}$ & $\begin{array}{l}300 \\
300 \\
300\end{array}$ & $\begin{array}{l}0.67 \\
0.73 \\
0.67\end{array}$ & $\begin{array}{l}8.4(-1) \\
8.4(-1) \\
8.4(-1)\end{array}$ & $\begin{array}{l}0.13 \\
0.14 \\
0.13\end{array}$ & 7.0 \\
\hline T2-D8 & $1.15(4)$ & 300 & 0.49 & $5.0(-1)$ & 0.16 & 7.7 \\
\hline $\begin{array}{l}T 2-D 9 \\
T 4-D 7 \\
T 3-D 7 \\
T 1-D 7\end{array}$ & $\begin{array}{l}1.33(4) \\
1.35(4) \\
1.35(4) \\
1.35(4)\end{array}$ & $\begin{array}{l}300 \\
600 \\
660 \\
600\end{array}$ & $\begin{array}{l}0.23 \\
0.43 \\
0.42 \\
0.37\end{array}$ & $\begin{array}{l}3.4(-1) \\
3.4(-1) \\
3.4(-1) \\
3.4(-1)\end{array}$ & $\left.\begin{array}{l}0.110 \\
0.103 \\
0.091 \\
0.088\end{array}\right\}$ & 6.0 \\
\hline
\end{tabular}

(a) The time listed is at the midpoint of the exposure period.

(b) Numbers in parentheses are exponents of base 10 . 
TABLE C-2

DEPOSITION COUPON DATA FROM TEST AB2

\begin{tabular}{|c|c|c|c|c|c|c|}
\hline $\begin{array}{l}\text { Sample } \\
\text { Number } \\
\end{array}$ & $\begin{array}{c}\text { Run Time } \\
(\mathrm{s})\end{array}$ & $\begin{array}{c}\text { Exposure } \\
\text { Time } \\
\text { (s) } \\
\end{array}$ & $\begin{array}{r}\text { Mass of } \mathrm{Na} \\
(\mathrm{mg}) \\
\end{array}$ & $\begin{array}{c}\text { Airborne } \mathrm{Na} \\
\left(\mathrm{g} / \mathrm{m}^{3}\right) \\
\end{array}$ & $\begin{array}{c}\text { Deposition } \\
\text { Velocity } \\
(\mathrm{cm} / \mathrm{s}) \\
\end{array}$ & $\begin{array}{c}\text { Particle } \\
\text { Diameter } \\
\text { (um) } \\
\end{array}$ \\
\hline $\begin{array}{l}\text { T3-01 } \\
\text { T2-D1 }\end{array}$ & $\begin{array}{l}1.30(3)^{(b)} \\
1.32(3)^{(b)}\end{array}$ & $\begin{array}{l}120 \\
120\end{array}$ & $\begin{array}{l}46.2 \\
28.9\end{array}$ & $\begin{array}{ll}9.8 & (0) \\
9.9 & (0)\end{array}$ & $\left.\begin{array}{l}1.92 \\
1.19\end{array}\right\}$ & 24.7 \\
\hline $\begin{array}{l}\text { T3-D2 } \\
\text { T2-D2 }\end{array}$ & $\begin{array}{l}2.10(3) \\
2.10(3)\end{array}$ & $\begin{array}{l}120 \\
120\end{array}$ & $\begin{array}{l}18.2 \\
19.1\end{array}$ & $\begin{array}{l}1.09(1) \\
1.09(1)\end{array}$ & $\begin{array}{l}0.68 \\
0.71\end{array}$ & 16.4 \\
\hline $\begin{array}{l}\text { T2-D3 } \\
\text { T4-D1 } \\
\text { T?-D1 }\end{array}$ & $\begin{array}{l}2.76(3) \\
2.76(3) \\
2.76(3)\end{array}$ & $\begin{array}{l}120 \\
120 \\
120\end{array}$ & $\begin{array}{l}33.5 \\
19.5 \\
16.3\end{array}$ & $\begin{array}{l}1.16(1) \\
1.16(1) \\
1.16(1)\end{array}$ & $\begin{array}{l}1.17 \\
0.68 \\
0.57\end{array}$ & 17.4 \\
\hline $\begin{array}{l}\text { T2-D4 } \\
\text { T3-D3 } \\
\text { T4-D2 }\end{array}$ & $\begin{array}{l}3.96(3) \\
3.96(3) \\
3.96(3)\end{array}$ & $\begin{array}{l}120 \\
120 \\
120\end{array}$ & $\begin{array}{l}19.8 \\
13.6 \\
17.7\end{array}$ & $\begin{array}{ll}1.0 & (1) \\
1.0 & (1) \\
1.0 & (1)\end{array}$ & $\begin{array}{l}0.81 \\
0.55 \\
0.72\end{array}$ & 16.0 \\
\hline $\mathrm{T} 1-\mathrm{D} 2$ & $4.08(3)$ & 120 & 11.4 & $9.4 \quad(0)$ & 0.49 & 13.5 \\
\hline $\begin{array}{l}\text { T3-D4 } \\
\text { T4-D3 } \\
\text { T2-D5 }\end{array}$ & $\begin{array}{l}5.72(3) \\
5.79(3) \\
5.79(3)\end{array}$ & $\begin{array}{r}30 \\
180 \\
180\end{array}$ & $\begin{array}{r}4.2 \\
7.2 \\
11.1\end{array}$ & $\begin{array}{ll}4.4 & (0) \\
4.2 & (0) \\
4.2 & (0)\end{array}$ & $\begin{array}{l}1.55 \\
0.47 \\
0.72\end{array}$ & 18.4 \\
\hline TI-D3 & $5.91 \quad(3)$ & 180 & 4.9 & $4.1 \quad(0)$ & 0.32 & 11.0 \\
\hline $\begin{array}{l}\text { T2-D6 } \\
\text { T3-D5 } \\
\text { T4-D4 }\end{array}$ & $\begin{array}{l}7.65(3) \\
7.65(3) \\
7.65(3)\end{array}$ & $\begin{array}{l}300 \\
300 \\
300\end{array}$ & $\begin{array}{l}3.8 \\
3.8 \\
3.5\end{array}$ & $\begin{array}{ll}2.1 & (0) \\
2.1 & (0) \\
2.1 & (0)\end{array}$ & $\begin{array}{l}0.29 \\
0.29 \\
0.27\end{array}$ & 10.3 \\
\hline T1-D4 & $7.77 \quad(3)$ & 300 & 2.0 & $2.08(0)$ & 0.16 & 7.6 \\
\hline $\begin{array}{l}\text { T3-D6 } \\
\text { T4-D5 } \\
\text { T2-D7 }\end{array}$ & $\begin{array}{l}9.66(3) \\
9.66(3) \\
9.66(3)\end{array}$ & $\begin{array}{l}600 \\
600 \\
600\end{array}$ & $\begin{array}{l}7.4 \\
1.9 \\
3.2\end{array}$ & $\begin{array}{l}1.14(0) \\
1.14(0) \\
1.14(0)\end{array}$ & $\begin{array}{l}0.53 \\
0.14 \\
0.23\end{array}$ & 10.5 \\
\hline $\begin{array}{l}\text { T3-D7 } \\
\text { T2-D9 } \\
\text { T4-D6 }\end{array}$ & $\begin{array}{l}1.38(4) \\
1.38(4) \\
1.38(4)\end{array}$ & $\begin{array}{l}1200 \\
1200 \\
1200\end{array}$ & $\begin{array}{l}1.0 \\
1.9 \\
2.0\end{array}$ & $\begin{array}{l}4.8(-1) \\
4.8(-1) \\
4.8(-1)\end{array}$ & $\begin{array}{l}0.085 \\
0.16 \\
0.17\end{array}$ & 7.2 \\
\hline $\mathrm{T} 1-\mathrm{D} 6$ & $1.60(4)$ & 1560 & 1.2 & $3.4(-1)$ & 0.11 & 6.4 \\
\hline T2-010 & $2.07 \quad(4)$ & 1800 & 1.1 & $1.9(-1)$ & 0.16 & 7.6 \\
\hline $\begin{array}{l}\text { T4-D7 } \\
\text { T1-D7 }\end{array}$ & $\begin{array}{l}2.22(4) \\
2.23(4)\end{array}$ & $\begin{array}{l}1800 \\
1800\end{array}$ & $\begin{array}{l}0.50 \\
0.52\end{array}$ & $\begin{array}{l}1.6(-1) \\
1.6(-1)\end{array}$ & $\begin{array}{l}0.085 \\
0.088\end{array} \mid$ & 5.7 \\
\hline
\end{tabular}

(a) The time listed is the midpoint of the exposure period.

(b) Numbers in parentheses are exponents of base 10 . 
APPENDIX D 
In this appendix, the numerical values used for input parameters in the HAA-3B code and SOFIRE-II code run cases are listed. Table D-1 presents the inputs for HAA-3B for each case used in the body of the report. The case number identified in Table $D-1$ corresponds to case numbers identified with each HAA-3B run presented in the body of the report. The four pretest runs are identified with the percentage of burned sodium assumed to have been aerosolized.

Some runs employed a time-dependent source rate table. These runs, identified as Cases 10, 11, 12, and 13, used the aerosol source rates 1 isted in Table 26.

The format and symbols used in Table D-1 are those given in the HAA-3B User Report, Reference 22.

Input variables in the SOFIRE-II code are listed in Table D-2. The card format and symbol definitions are those provided in the User Report, Reference 21. 
TABLE D-1

INPUT PARAMETER LIST FOR HAA-3B CODE CASES

\section{Input Parameter Name}

Source Rate (Particles $/ \mathrm{cm}^{3} \mathrm{~s}$ )

Source Sigma (volume)

Source $50 \%$ volume Size $\left(\mathrm{mm}^{3}\right)$ Initial Concentration of Aerosol
(Particles $\left./ \mathrm{cm}^{3}\right)$

Aerosol sigma (Vol ume)

Aerosol 50\% Volume Size $\left(u \mathrm{~m}^{3}\right)$

Initial Time (s)

Source Cutoff Time (s)

Maximum Time (s)

Time Step, Initial (s)

Leakage Rate (per s)

Area of Floor/Volume (per $\mathrm{cm}$ )

Density of Aerosol Material $\left(\mathrm{g} / \mathrm{cm}^{3}\right)$

Viscosity of Air (dyne $\mathrm{s} / \mathrm{cm}^{2}$ )

Area of Wall/Volume (per cm)

Temperature (K)

Plating Thickness $(\mathrm{cm})$

Volume/Volume Maximum Shutoff Ratio

Plating Thickness After Source Cutoff

Volume of Chamber $\left(\mathrm{cm}^{3}\right)$

Rate Ratio at Which SSM Begins

Time for SSM Shutoff

Density Modification Factor

Klyachko Velocity $(1=$ yes $/ 0=$ no $)$

Density of Air $\left(\mathrm{g} / \mathrm{cm}^{3}\right)$

Efficiency

\begin{tabular}{|c|c|c|c|c|c|c|c|c|c|c|c|c|}
\hline \multirow{2}{*}{$\frac{\text { Symbol }}{\text { so }}$} & \multicolumn{2}{|c|}{$\begin{array}{c}\text { Pretest } \\
10 \% *\end{array}$} & \multicolumn{2}{|c|}{$\begin{array}{c}\text { Pretest } \\
20 \% \star\end{array}$} & \multicolumn{2}{|c|}{$\begin{array}{c}\text { Pretest } \\
30 \%^{\star}\end{array}$} & \multicolumn{2}{|c|}{$\begin{array}{c}\text { Pretest } \\
40 \% \star\end{array}$} & \multicolumn{2}{|c|}{$\begin{array}{c}\text { Posttest } \\
\text { Case } 1 \\
\end{array}$} & \multicolumn{2}{|c|}{$\begin{array}{c}\text { Posttest } \\
\text { Case } 2 \\
\end{array}$} \\
\hline & 5.316 & $E+4$ & 1.063 & $E+5$ & 1.595 & $E+5$ & 2.126 & $E+5$ & 1.529 & $E+5$ & 1.529 & $E+5$ \\
\hline SIGSOR & 8.00 & $E+0$ & 8.00 & $E+0$ & 8.00 & $E+0$ & 8.00 & $E+0$ & 8.00 & $E+0$ & 8.00 & $E+0$ \\
\hline VSOR & 1.250 & $E-1$ & 1.250 & $E-1$ & 1.250 & $E-1$ & 1.250 & $E-1$ & 1.250 & $E-1$ & 1.250 & $E-1$ \\
\hline $\operatorname{XIN}(1)$ & 0.0 & & 0.0 & & 0.0 & & 0.0 & & 0.0 & & 0.0 & \\
\hline SIGAIR & 0.0 & & 0.0 & & 0.0 & & 0.0 & & 0.0 & & 0.0 & \\
\hline VAIR & 0.0 & & 0.0 & & 0.0 & & 0.0 & & 0.0 & & 0.0 & \\
\hline TO & 0.0 & & 0.0 & & 0.0 & & 0.0 & & 0.0 & & 0.0 & \\
\hline TAUIN & 3.60 & $E+3$ & 3.60 & $E+3$ & 3.60 & $E+3$ & 3.60 & $E+3$ & 3.60 & $E+3$ & 3.60 & $E+3$ \\
\hline TMAXIN & 2.592 & $E+5$ & 2.592 & $E+5$ & 2.592 & $E+5$ & 2.592 & $E+5$ & 4.00 & $E+5$ & 4.00 & $E+5$ \\
\hline HIN & 1.00 & $E-2$ & 1.00 & $E-2$ & 1.00 & $E-2$ & 1.00 & $E-2$ & 1.00 & $E-2$ & 1.00 & $E-2$ \\
\hline TOL IN & 1.00 & $E-3$ & 1.00 & $E-3$ & 1.00 & $E-3$ & 1.00 & $E-3$ & 1.00 & $E-3$ & .1 .00 & $E-3$ \\
\hline RVL & 1.28 & $E-7$ & 1.28 & $E-7$ & 1.28 & $E-7$ & 1.28 & $E-7$ & 2.32 & $E-7$ & 2. 32 & $E-7$ \\
\hline AFOV & 8.366 & $E-4$ & 8. 366 & $E-4$ & 8.366 & $E-4$ & 8.366 & $E-4$ & 1.040 & $E-3$ & 5.360 & $E-4$ \\
\hline RHO & 2.738 & $E+0$ & 2.738 & $E+0$ & 2.738 & $E+0$ & 2.738 & $E+0$ & 2.42 & $E+0$ & 2.42 & $E+0$ \\
\hline VISC & 1.800 & $E-4$ & 1.800 & $E-4$ & 7.800 & $E-4$ & 1.800 & $E-4$ & 2.00 & $E-4$ & 2.00 & $E-4$ \\
\hline AWOV & 5.315 & $E-3$ & 5.315 & $E-3$ & 5.315 & $E-3$ & 5.375 & $E-3$ & 1.776 & $E-2$ & 6.720 & $E-3$ \\
\hline TEMP & 4.210 & $E+2$ & 4.210 & $E+2$ & 4.210 & $E+2$ & 4.210 & $E+2$ & 3.38 & $E+2$ & 3.38 & $E+2$ \\
\hline DELTA & 1.00 & $E-5$ & 1.00 & $E-5$ & 1.00 & $E-5$ & 1.00 & $E-5$ & 1.00 & $E-5$ & 1.00 & $E-5$ \\
\hline EPSL & 1.00 & $E-6$ & 1.00 & $E-6$ & 1.00 & $E-6$ & 1.00 & $E-6$ & 1.00 & $E-6$ & 1.00 & $E-6$ \\
\hline DELTA 1 & 1.00 & $E-5$ & 1.00 & $E-5$ & 1.00 & $E-5$ & 1.00 & $E-5$ & 1.00 & $E-5$ & 1.00 & $E-5$ \\
\hline VOL & 8.519 & $E+8$ & 8.519 & $E+8$ & 8.519 & $E+8$ & 8.519 & $E+8$ & 8.519 & $E+8$ & 8.519 & $E+8$ \\
\hline EPSN & 6.00 & $E-1$ & 6.00 & $E-1$ & 6.00 & $E-1$ & 6.00 & $E-1$ & 3.00 & $E-1$ & 3.00 & $E-1$ \\
\hline EPSM & 1.700 & $E+5$ & 1.700 & $E+5$ & 1.700 & $E+5$ & 1.700 & $E+5$ & 4.00 & $E+5$ & 4.00 & $E+5$ \\
\hline ALPHA & 2.500 & $E-1$ & 2.500 & $E-1$ & 2.500 & $E-1$ & 2.500 & $E-1$ & 2.00 & $E-1$ & 2.00 & $E-1$ \\
\hline KLYACH & 1 & & 1 & & 1 & & 1 & & 1 & & 1 & \\
\hline RHOAIR & 1.180 & $E-3$ & 1.180 & $E-3$ & 1.180 & $E-3$ & 1.180 & $E-3$ & 1.35 & $E-3$ & 1.35 & $E-3$ \\
\hline EFF & 1.00 & $E+0$ & 1.00 & $E+0$ & 1.00 & $E+0$ & 1.00 & $E+0$ & 1.00 & $E+0$ & 1.00 & $E+0$ \\
\hline
\end{tabular}

ॠThe percentages are percent of burned sodium assumed to be aerosolized. 


\section{TABLE D-1}

\section{(CONTINUED)}

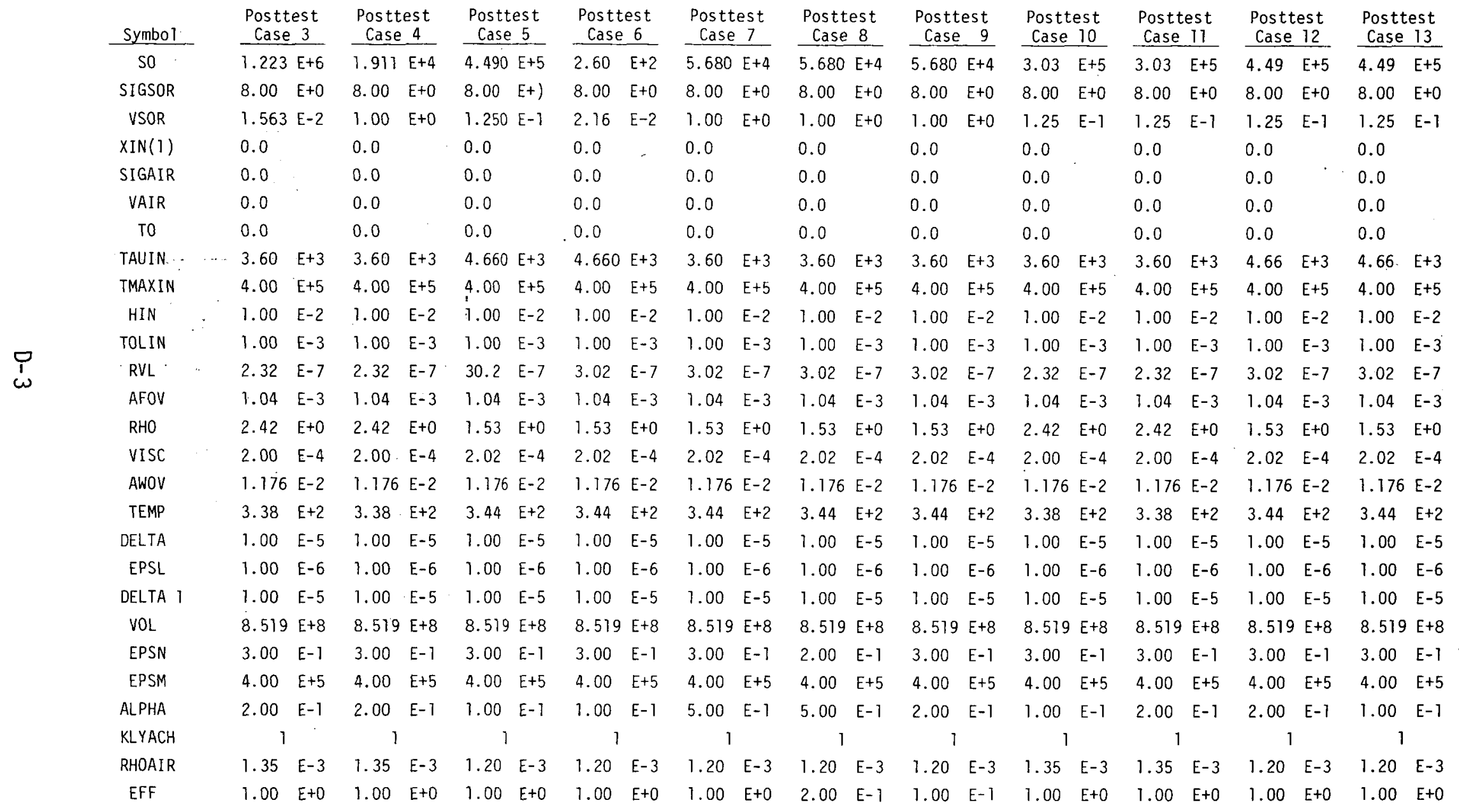


TABLE D-2

SOFIRE-II INPUT PARAMETERS

SOFIRE INPUT DATA

FORMAT E10.0

\begin{tabular}{|c|c|c|c|c|c|c|c|c|}
\hline $\begin{array}{c}\text { CARD \# } \\
0\end{array}$ & \multicolumn{8}{|c|}{$\begin{array}{l}\text { COL } 1=1 \text { FOR ONE CELL, } 2 \text { FOR TWO CELL. COL } 2=\text { BLANK } \\
\text { COL } 3-80 \quad \text { TITLE }\end{array}$} \\
\hline 1 & A) 48.0 & $\begin{array}{ll} & \\
& 48.0\end{array}$ & $\begin{array}{ll}A 3 & \\
& 0.001\end{array}$ & A4 5100.0 & A5 - & A6 & A7 & $\begin{array}{l}\text { A8 } \\
70.0\end{array}$ \\
\hline 2 & $\begin{array}{l}\mathrm{AFl} \\
0.7\end{array}$ & $\begin{array}{r}\mathrm{AF}^{2} \\
0\end{array}$ & $\begin{array}{r}\mathrm{AF}^{3} \\
0 \\
\end{array}$ & $\begin{array}{r}\mathrm{AF} 4 \\
0 \\
\end{array}$ & $\begin{array}{r}\text { AF5 } \\
-\end{array}$ & $\begin{array}{r}\text { AF6 } \\
- \\
\end{array}$ & $\begin{array}{r}\mathrm{AFT3} \\
0 \\
\end{array}$ & $\begin{array}{l}\text { ANA } \\
\quad 1.44 \\
\end{array}$ \\
\hline 3 & $\begin{array}{l}\text { CAPFI } \\
0.842\end{array}$ & $\begin{array}{l}\text { CAPF2 } \\
0.861 \\
\end{array}$ & $\begin{array}{c}\text { CAPF3 } \\
0.861 \\
\end{array}$ & $\begin{array}{l}\text { CAPF4 } \\
0.861 \\
\end{array}$ & $\begin{array}{c}\text { CAPF5 } \\
1.684 \\
\end{array}$ & $\begin{array}{l}\text { CAPF6 } \\
0.035 \\
\end{array}$ & $\begin{array}{l}\text { CAPF7 } \\
3.369 \\
\end{array}$ & $\begin{array}{l}\text { CAPF8 } \\
0.125 \\
\end{array}$ \\
\hline 4 & $\begin{array}{c}\text { CAPCl } \\
1.0\end{array}$ & $\begin{array}{c}\text { CAPC2 } \\
1.0\end{array}$ & CAPC 3 & CAPC4 & CAPC5 & CAPC6 & CAPC7 & CAPC8 \\
\hline 5 & $\begin{array}{c}\text { CAPU1 } \\
3.03\end{array}$ & $\begin{array}{l}\text { CAPU2 } \\
0.125\end{array}$ & CAPU 3 & CAPU $4^{\circ}$ & CAPU5 & CAPU 6 & CAPU7 & CAPU8 \\
\hline 6 & CAPFSI & CAPFS2 & CAPFS 3 & CAPFS 4 & CAPFS5 & CAPFS 6 & CAPFS 7 & CAPFS 8 \\
\hline 7 & CAPWSI & CAPWS2 & CAPWS 3 & CAPWS4 & CAPWS5 & CAPWS6 & CAPWS7 & CAPWS8 \\
\hline 8 & $\begin{array}{r}\text { CPAC } \\
0.24\end{array}$ & CPAS & ${ }_{0.223}{ }^{\text {CCI }}$ & CSI & ${ }_{0}^{\mathrm{CON}}$ & $\begin{array}{c}\mathrm{COOL} 1 \\
0\end{array}$ & F3 0 & HIN \\
\hline 9 & P1 & $\overline{P 2}$ & P3 & P4 & ${ }^{Q}{ }_{3900}$ & CAPEMI & TEMI I & $\begin{array}{l}\text { RHBA } \\
0.07\end{array}$ \\
\hline 10 & $\begin{array}{l}\text { PER } \\
0\end{array}$ & $\begin{array}{l}\text { SOD } \\
1000\end{array}$ & $\begin{array}{c}\text { SUMCI } \\
0\end{array}$ & $\begin{array}{c}\text { SUMSI } \\
0\end{array}$ & $\begin{array}{r}\text { TAIR } \\
538\end{array}$ & $\begin{array}{c}\text { TABL I } \\
0\end{array}$ & $\begin{array}{c}\text { TABL2 } \\
0\end{array}$ & $\begin{array}{c}\text { DELTYM } \\
0\end{array}$ \\
\hline 11 & $\begin{array}{r}\text { PRT } \\
0.01\end{array}$ & $\begin{array}{ll}\text { PA } & \\
& 2073.6\end{array}$ & ${ }_{1635}$ & $\begin{array}{l}\text { TF1 I } \\
538\end{array}$ & $\begin{array}{r}\text { TWCII } \\
538\end{array}$ & $\begin{array}{r}\text { TUC1 I } \\
538\end{array}$ & TFS II & TWS1 I \\
\hline 12 & $\begin{array}{r}\text { PRT2 } \\
0.10\end{array}$ & $\begin{array}{c}\text { PGASCI } \\
2592\end{array}$ & \begin{tabular}{|r|} 
TGASCI \\
538
\end{tabular} & $\begin{array}{l}\text { TF1 } \\
538\end{array}$ & $\begin{array}{r}\text { TWCI } \\
538\end{array}$ & $\begin{array}{l}\text { TUSI } \\
538\end{array}$ & TFSI & TWS I \\
\hline 13 & $\begin{array}{r}\text { PRT3 } \\
0.50\end{array}$ & PGASS I & TGASSI & ${ }_{538}$ & $\begin{array}{r}\text { TWCA } \\
538\end{array}$ & $\begin{array}{r}\text { TUCA } \\
538\end{array}$ & TFSA & TWSA \\
\hline 14 & $\begin{array}{r}\text { U27 } \\
\quad 1.439\end{array}$ & $\begin{array}{r}\text { U22 } \\
0.720\end{array}$ & $\begin{array}{r}U 23 \\
0.720\end{array}$ & $\begin{array}{r}\text { U24 } \\
3.592\end{array}$ & $\begin{array}{r}\text { U25 } \\
0.02\end{array}$ & $\begin{array}{r}0.026 \\
0.02\end{array}$ & $\begin{array}{r}\mathrm{U} 27 \\
0.324\end{array}$ & $\begin{array}{r}\text { U28 } \\
1.0\end{array}$ \\
\hline 15 & $\begin{array}{l}\text { U31 } \\
1.0\end{array}$ & U32 & U33 & U34 & U35 & U36 & U37 & U38 \\
\hline 16 & $\begin{array}{r}\text { U41 } \\
0.5\end{array}$ & $\begin{array}{r}\text { U42 } \\
0.5\end{array}$ & U43 & U44 & U45 & U46 & U47 & U48 \\
\hline 17 & U51 & U52 & U53 & U54 & U55 & U56 & U57 & U58 \\
\hline 18 & U61 & U62 & U63 & U64 & U65 & U66 & 067 & 468 \\
\hline 19 & $\begin{array}{r}\text { VOLACI } \\
30086\end{array}$ & VOLASI & $\begin{array}{c}\text { XMULT } \\
0.9\end{array}$ & $X L$ & $\begin{array}{r}\text { XMAX } \\
72\end{array}$ & XMI & AFLOW & FPC \\
\hline 20 & $\begin{array}{l}Y C(1) \\
2200\end{array}$ & $\begin{array}{r}Y C(2) \\
1100\end{array}$ & $\begin{array}{r}Y C(3) \\
1100\end{array}$ & $\begin{array}{r}Y C(4) \\
\quad 1100\end{array}$ & $\begin{array}{c}Y C(5) \\
1100\end{array}$ & $\begin{array}{c}Y C(6) \\
1100\end{array}$ & $\begin{array}{c}Y C(7) \\
1100\end{array}$ & $\begin{array}{r}Y C(8) \\
0.0\end{array}$ \\
\hline 21 & $\begin{array}{r}\text { TCI (1) } \\
538\end{array}$ & $\begin{array}{r}\text { TCI (2) } \\
538 \\
\end{array}$ & \begin{tabular}{|r|} 
TCI (3) \\
538 \\
\end{tabular} & $\begin{array}{r}\text { TCI (4) } \\
538 \\
\end{array}$ & \begin{tabular}{|r|} 
TCI $(5)$ \\
538 \\
\end{tabular} & \begin{tabular}{|r|} 
TCI $(6)$ \\
538 \\
\end{tabular} & $\begin{array}{r}\text { TCI (7) } \\
538 \\
\end{array}$ & \begin{tabular}{|r|} 
TCI ( 8$)$ \\
538 \\
\end{tabular} \\
\hline 22 & $\begin{array}{r}\text { CAPC (1) } \\
87.0\end{array}$ & $\begin{array}{r}\text { CAPC (2) } \\
87.0 \\
\end{array}$ & $\begin{array}{r}\text { CAPC (3) } \\
87.0 \\
\end{array}$ & $\begin{array}{r}\text { CAPC (4) } \\
87.0 \\
\end{array}$ & $\begin{array}{r}\text { CAPC (5) } \\
87.0 \\
\end{array}$ & $\begin{array}{r}\text { CAPC (6) } \\
87.0 \\
\end{array}$ & $\begin{array}{r}\mathrm{CAPC}(7) \\
87.0 \\
\end{array}$ & $\begin{array}{r}\mathrm{CAPC}(8) \\
87.0\end{array}$ \\
\hline 23 & $\begin{array}{c}\text { CURVE } \\
0\end{array}$ & XSCALE & YSCALE & & & & & \\
\hline
\end{tabular}


TABLE D-2

(CONTINUED)

SOFIRE INPUT DATA

FORMAT ET0.0

\begin{tabular}{|c|c|c|c|c|c|c|c|c|}
\hline $\begin{array}{c}\text { CARD \# } \\
0\end{array}$ & $\begin{array}{l}\mathrm{COL} \\
\mathrm{COL}\end{array}$ & $\begin{array}{ll}1=1 & \text { FOR } \\
3-80 & T I\end{array}$ & $\begin{array}{l}\text { JNE CELL, } \\
\text { PLE } \\
\text { POS }\end{array}$ & $\begin{array}{l}2 \text { FOR TWO } \\
\text { TTEST PREDI }\end{array}$ & $\begin{array}{l}\text { CELL. COL } \\
\text { ICTION FOR }\end{array}$ & $2=$ BLANK & & \\
\hline 1 & $\begin{array}{ll}A 1 & \\
& 48.0 \\
\end{array}$ & $\begin{array}{ll}A 2 & \\
& 48.0 \\
\end{array}$ & $\begin{array}{ll}A 3 & \\
& 0.001\end{array}$ & A4 $\begin{array}{ll} & \\
& 5550.0 \\
\end{array}$ & A5 & $A 6$ & A7 & $\begin{array}{l}\text { A8 } \\
\quad 5167.0\end{array}$ \\
\hline 2 & $\begin{array}{r}A F I \\
0.9 \\
\end{array}$ & $\begin{array}{r}\mathrm{AF}^{2} \\
0 \\
\end{array}$ & $\begin{array}{r}A F 3 \\
0\end{array}$ & $\begin{array}{r}\text { AF4 } \\
0 \\
\end{array}$ & AF5 & AF6 & $\begin{array}{r}\text { AF13 } \\
0 \\
\end{array}$ & $\begin{array}{l}\text { ANA } \\
2.32 \\
\end{array}$ \\
\hline 3 & $\begin{array}{r}\text { CAPF1 } \\
0.842 \\
\end{array}$ & $\begin{array}{c}\text { CAPF2 } \\
0.861 \\
\end{array}$ & $\begin{array}{r}\text { CAPF3 } \\
0.861 \\
\end{array}$ & \begin{tabular}{|c|} 
CAPF4 \\
0.861 \\
\end{tabular} & \begin{tabular}{|c|} 
CAPF5 \\
1.684 \\
\end{tabular} & $\begin{array}{r}\text { CAPF6 } \\
0.035 \\
\end{array}$ & $\begin{array}{l}\text { CAPF7 } \\
3.369 \\
\end{array}$ & $\begin{array}{l}\text { CAPF8 } \\
0.125 \\
\end{array}$ \\
\hline 4 & $\begin{array}{r}\text { CAPC1 } \\
1.0 \\
\end{array}$ & $\begin{array}{c}\text { CAPC2 } \\
1.0 \\
\end{array}$ & CAPC 3 & CAPC4 & CAPC5 & CAPC6 & CAPC7 & CAPC 8 \\
\hline 5 & $\begin{array}{r}\text { CAPU1 } \\
3.03 \\
\end{array}$ & $\begin{array}{l}\text { CAPU2 } \\
0.125 \\
\end{array}$ & CAPU3 & CAPU4 & CAPU5 & CAPU6 & CAPU7 & CAPU8 \\
\hline 6 & CAPFST & CAPFS2 & CAPFS3 & CAPFS4 & CAPFS5 & CAPFS6 & CAPFS 7 & CAPFSB \\
\hline 7 & CAPWS I & CAPWS2 & CAPWS 3 & CAPWS4 & CAPWS5 & CAPWS6 & CAPWS 7 & CAPWS8 \\
\hline 8 & $\begin{array}{r}\text { CPAC } \\
0.24 \\
\end{array}$ & CPAS & $\begin{array}{r}\text { CCI } \\
0.223\end{array}$ & CSI & $\begin{array}{r}\mathrm{CON} \\
0.0 \\
\end{array}$ & $\begin{array}{r}\mathrm{COOLI} \\
0.0 \\
\end{array}$ & F3 0.0 & HIN \\
\hline 9 & PI & P2 & P3 & P4 & $\begin{array}{|ll|}Q C & \\
& 4358.0 \\
\end{array}$ & CAPEMT & TEMI I & $\begin{array}{l}\text { RHBA } \\
0.075 \\
\end{array}$ \\
\hline 10 & $\begin{array}{r}\text { PER } \\
0 \\
\end{array}$ & $\begin{array}{r}S O D \\
1000.0 \\
\end{array}$ & $\begin{array}{c}\text { SUMCI } \\
0.0 \\
\end{array}$ & $\begin{array}{r}\text { SUMSI } \\
0.0 \\
\end{array}$ & $\begin{array}{l}\text { TAIR } \\
\quad 538.0 \\
\end{array}$ & $\begin{array}{r}\text { TABL } 1 \\
0.0 \\
\end{array}$ & $\begin{array}{r}\text { TABL2 } \\
0.0 \\
\end{array}$ & $\begin{array}{r}\text { DELTYM } \\
0.0 \\
\end{array}$ \\
\hline 11 & $\begin{array}{r}\text { PRT1 } \\
0.01 \\
\end{array}$ & $\begin{array}{l}\text { PA } \\
2067.8 \\
\end{array}$ & \begin{tabular}{|l} 
TSI \\
$\quad 1635$ \\
\end{tabular} & $\begin{array}{r}\text { TFII } \\
538.0 \\
\end{array}$ & $\begin{array}{l}\text { TWC II } \\
538.0 \\
\end{array}$ & $\begin{array}{r}\text { TUC11 } \\
538.0 \\
\end{array}$ & TFS1I & TWSII \\
\hline 12 & $\begin{array}{r}\text { PRT2 } \\
0.10 \\
\end{array}$ & $\begin{array}{r}\text { PGASCI } \\
2556.3 \\
\end{array}$ & $\begin{array}{r}\text { TGASCI } \\
538.0 \\
\end{array}$ & $\begin{array}{r}\text { TFI } \\
538.0 \\
\end{array}$ & $\begin{array}{l}\text { TWCI } \\
538.0 \\
\end{array}$ & $\begin{array}{r}\text { TUSI } \\
538.0 \\
\end{array}$ & TFSI & TWSI \\
\hline 13 & $\begin{array}{r}\text { PRT3 } \\
0.50 \\
\end{array}$ & PGASSI & TGASS I & $\begin{array}{r}\text { TFA } \\
538.0 \\
\end{array}$ & $\begin{array}{l}\text { TWCA } \\
538.0 \\
\end{array}$ & $\begin{array}{r}\text { TUCA } \\
538.0 \\
\end{array}$ & TFSA & TWSA \\
\hline 14 & $\begin{array}{r}\text { U21 } \\
\quad 1.439 \\
\end{array}$ & $\begin{array}{r}\text { U22 } \\
0.72 \\
\end{array}$ & $\begin{array}{r}\mathrm{U} 23 \\
\quad 0.72 \\
\end{array}$ & $\begin{array}{r}24 \\
\quad 3.592 \\
\end{array}$ & $\begin{array}{r}025 \\
\quad 0.020 \\
\end{array}$ & $\begin{array}{r}\mathrm{U} 26 \\
0.020 \\
\end{array}$ & $\begin{array}{l}\text { U27 } \\
\quad 0.324 \\
\end{array}$ & $\begin{array}{r}\text { U28 } \\
\quad 1.0 \\
\end{array}$ \\
\hline 15 & $\begin{array}{r}\text { U31 } \\
\quad 1.0 \\
\end{array}$ & U32 & U33 & U34 & U35 & 436 & U37 & U38 \\
\hline 16 & $\begin{array}{r}\text { U41 } \\
0.324 \\
\end{array}$ & $\begin{array}{r}\text { U42 } \\
1.0 \\
\end{array}$ & U43 & U44 & U45 & U46 & U47 & U48 \\
\hline 17 & U51 & U52 & U53 & U54 & U55 & U56 & U57 & U58 \\
\hline 18 & U61 & U62 & U63 & U64 & U65 & U66 & U67 & U68 \\
\hline 19 & $\begin{array}{r}\text { VOLACI } \\
30086\end{array}$ & VOLASI & $\begin{array}{r}\text { XMULT } \\
0.9 \\
\end{array}$ & $X L$ & $\begin{array}{r}X M A X \\
\quad 72.0 \\
\end{array}$ & XMI & AFLOW & FPC \\
\hline 20 & $\begin{array}{r}Y C(1) \\
0.0 \\
\end{array}$ & $Y C(2)$ & $Y C(3)$ & $Y C(4)$ & $Y C(5)$ & $Y C(6)$ & $Y C(7)$ & $Y C(8)$ \\
\hline 21 & $\begin{array}{r}\text { TCI (1) } \\
538.0 \\
\end{array}$ & $\operatorname{TCI}(2)$ & $\operatorname{TCI}(3)$ & $\operatorname{TCI}(4)$ & $\operatorname{TCI}(5)$ & $\operatorname{TCI}(6)$ & $\mathrm{TCI}(7)$ & TCI (8) \\
\hline 22 & $\begin{array}{r}\text { CAPC (1) } \\
5802.0 \\
\end{array}$ & CAPC (2) & $\operatorname{CAPC}(3)$ & CAPC (4) & CAPC (5) & $\operatorname{CAPC}(6)$ & CAPC (7) & $\operatorname{CAPC}(8)$ \\
\hline 23 & $\begin{array}{c}\text { CURVE } \\
0 \\
\end{array}$ & XSCALE & YSCALE & & & & & \\
\hline
\end{tabular}


APPENDIX E 


\section{INSTRUMENTATION}

\section{A. THERMOCOUPLE LOCATIONS}

The locations of the 44 chromel-alume1 (Type $K$ ) thermocouples used to measure temperatures in Tests $A B 1$ and $A B 2$ are described in Table E-1. Angles specified are measured clockwise from a radius drawn from the vessel center to the midpoint of the large equipment door.

\section{B. IN-VESSEL CLUSTERED FILTER SAMPLER LOCATIONS}

Ten filter clusters were positioned at the spatial locations described in Figure E-1. The clusters were aligned so that the aerosol inlets were at the bottom of the cluster. 
TABLE E-1

\title{
THERMOCOUPLE LOCATIONS
}

\author{
Thermocouple \\ Number \\ 2 \\ 3 \\ 4 \\ 5 \\ 6 \\ 7 \\ 8 \\ 9 \\ 10

Description and Location
Inside CV surface, tophead
center, elevation $+10.98 \mathrm{~m}$ \\ CV atmosphere, $30.5 \mathrm{~cm}$ from \\ CV wal1, $270^{\circ},+10.67 \mathrm{~m}$ \\ Outside steel surface, top- \\ head center, $+10.98 \mathrm{~m}$ \\ Outside steel surface, $180^{\circ}$, \\ $+6.1 \mathrm{~m}$ \\ Outside steel surface, $180^{\circ}$, \\ $+1.22 \mathrm{~m}$ \\ Outside steel surface, $180^{\circ}$, \\ $-3.05 \mathrm{~m}$ \\ Outside steel surface, bot- \\ tom head, $135^{\circ},-8.54 \mathrm{~m}$ \\ Air, $30.5 \mathrm{~cm}$ outside $\mathrm{CV}$, \\ $260^{\circ},+9.15 \mathrm{~m}$ \\ Air, $30.5 \mathrm{~cm}$ outside $\mathrm{CV}$, \\ $180^{\circ},+2.13 \mathrm{~m}$ \\ Air, $30.5 \mathrm{~cm}$ outside $\mathrm{CV}$, \\ $180^{\circ},-6.1 \mathrm{~m}$ \\ Canyon air exhaust filter \\ $\mathrm{CV}$ a tmosphere over $\mathrm{Na}$, \\ $15.24 \mathrm{~cm}$ above burn pan \\ floor, center \\ Between two layers of fire- \\ brick, pan center \\ Sodium TK-3, bottom head \\ Sodium TK-3, $91.44 \mathrm{~cm}$ above \\ bottom \\ Sodium TK-3, top head \\ Inside CV surface, $100^{\circ}$, \\ $+1.52 \mathrm{~m}$ \\ CV atmosphere, $0.95 \mathrm{~cm}$ from \\ wa $11,100^{\circ},+1.52 \mathrm{~m}$ \\ CV atmosphere, $1.9 \mathrm{~cm}$ from \\ wall, $100^{\circ},+1.52 \mathrm{~m}$ \\ $\mathrm{CV}$ atmosphere, $5.08 \mathrm{~cm}$ from \\ wal1, $100^{\circ},+1.52 \mathrm{~m}$ \\ $\mathrm{CV}$ atmosphere, $30.48 \mathrm{~cm}$ from \\ wall, $100^{\circ},+1.52 \mathrm{~m}$. \\ Inside $C V$ surface, $60^{\circ}$, \\ $+7.32 \mathrm{~m}$
}

Thermocouple Number
Description and Location

Inside $\mathrm{CV}$ surfáce, $260^{\circ}$, $+7.32 \mathrm{~m}$

$\mathrm{CV}$ atmosphere, $30.48 \mathrm{~cm}$ from wall, $345^{\circ},+7.32 \mathrm{~m}$

$\mathrm{CV}$ atmosphere, $30.48 \mathrm{~cm}$ from wall, $170^{\circ},+7.32 \mathrm{~m}$

$\mathrm{CV}$ atmosphere, $60.96 \mathrm{~cm}$ from wall, $236^{\circ},+2.13 \mathrm{~m}$

Inside CV surface, $180^{\circ}$, $+1.22 \mathrm{~m}$

$\mathrm{CV}$ atmosphere, $30.48 \mathrm{~cm}$ from wal $1,85^{\circ},+1.22 \mathrm{~m}$

Inside CV surface, $345^{\circ}$, $+1.22 \mathrm{~m}$

Inside $\mathrm{CV}$ surface, $30^{\circ}$, $-5.79 \mathrm{~m}$

Inside $\mathrm{CV}$ surface, $95^{\circ}$, $-5.79 \mathrm{~m}$

Inside CV surface, $225^{\circ}$, $-5.79 \mathrm{~m}$

$\mathrm{CV}$ atmosphere, $30.48 \mathrm{~cm}$ from wal1, $375^{\circ},-5.79 \mathrm{~m}$

Inside CV surface, $300^{\circ}$, $-5.79 \mathrm{~m}$

Inside CV surface, bottom near center, $-9.15 \mathrm{~m}$

$\mathrm{CV}$ atmosphere, $30.48 \mathrm{~cm}$ from wall, 0 m elevation

$\mathrm{CV}$ a tmosphere, $30.48 \mathrm{~cm}$ from wall, 0 m elevation

$C V$ atmosphere, $30.48 \mathrm{~cm}$ from wall, $0 \mathrm{~m}$ elevation

Sodium pool, $2.54 \mathrm{~cm}$ above burn pan floor, center

Sodium pool, $6.35 \mathrm{~cm}$ above burn pan floor, center

Sodium pool, $10.16 \mathrm{~cm}$ above burn pan floor, center

Between firebrick and pan, center

CV atmosphere over sodium, $40.64 \mathrm{~cm}$ above burn pan floor, center

CV atmosphere on Cluster No. 5 near CV center 


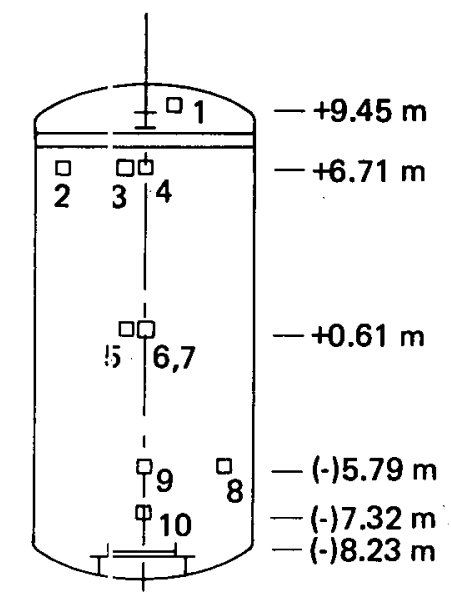

LOOKINIG TOWARD $180^{\circ}$

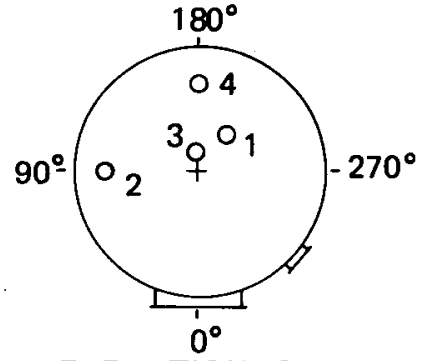

ELEVATION $+6.71 \mathrm{~m}$ AND ABOVE

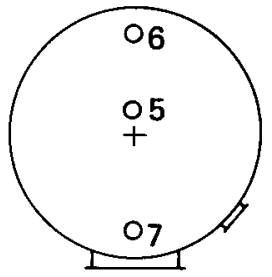

ELEVATION $+0.61 \mathrm{~m}$

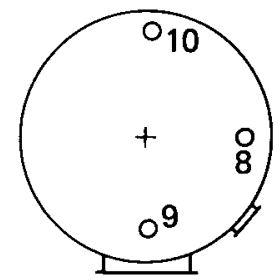

ELEVATION (-)5.79 AND BELOW

FIGURE E-1. Filter Cluster Locations in the CSTF Containment Vessel Test $A B 1$. 
APPENDIX $F$ 
Representative temperature and pressure data are presented in Tables $\mathrm{F}-1$ through F-4. The data listed are but a small fraction of those recorded by the data logger. Any reader needing more digital data should contact the Hanford Engineering Development Laboratory, Richland, WA 99352. 
TABLE F-1

\section{WALL STEEL TEMPERATURES IN AB1}

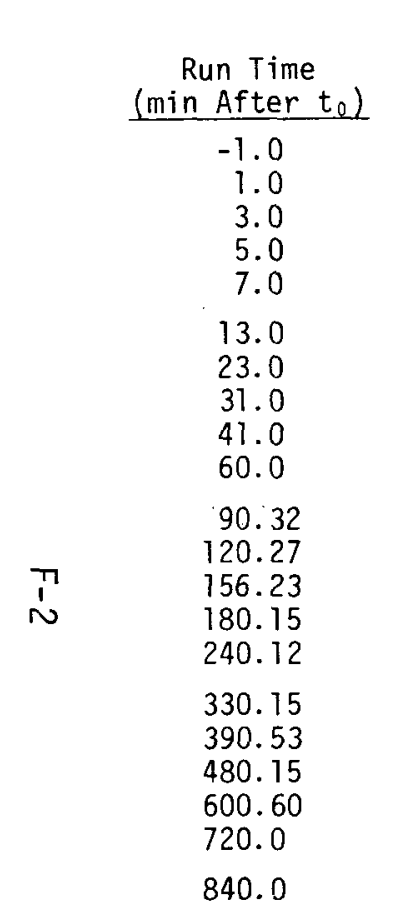

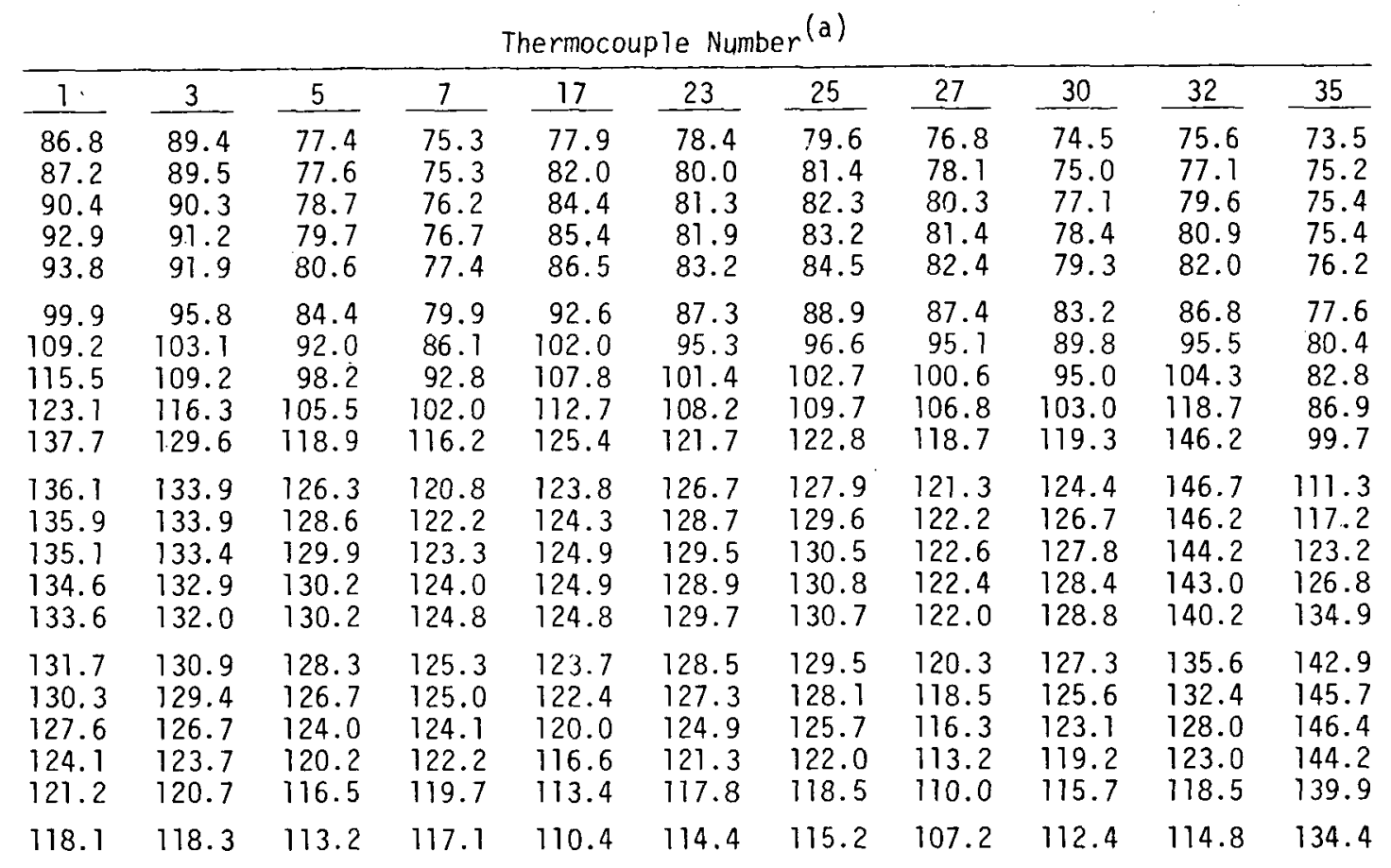

\begin{tabular}{cc}
$\begin{array}{c}\text { Average Steel } \\
\text { Temperature } \\
\left({ }^{\circ} \mathrm{F}\right)\end{array}$ & $\begin{array}{c}\text { Standard } \\
\text { Deviation } \\
\left({ }^{\circ} \mathrm{F}\right)\end{array}$ \\
\hline $\begin{array}{c}78.66 \\
79.85\end{array}$ & 5.02 \\
81.45 & 4.86 \\
82.46 & 5.13 \\
83.44 & 5.53 \\
87.62 & 5.54 \\
95.01 & 6.59 \\
100.94 & 8.05 \\
108.45 & 8.83 \\
123.29 & 9.74 \\
127.2 & 12.01 \\
128.68 & 9.24 \\
129.49 & 7.91 \\
129.80 & 6.43 \\
130.15 & 5.76 \\
129.45 & 5.15 \\
128.31 & 6.06 \\
126.07 & 6.91 \\
122.70 & 7.55 \\
119.26 & 7.84 \\
115.95 & 7.59 \\
& 6.95
\end{tabular}

$\overline{(a)}$ See Table E-l for location. 
TABLE F-2

ATMOSPHERE TEMPERATURES AND PRESSURES IN ABI

\begin{tabular}{|c|c|c|c|c|c|c|c|c|}
\hline \multirow{2}{*}{$\begin{array}{c}\text { Run Time } \\
\left.\text { (min After } t_{0}\right)\end{array}$} & \multicolumn{8}{|c|}{ Thermocouple Number (a) } \\
\hline & 2 & 22 & 24 & 26 & 28 & 31 & 33 & 44 \\
\hline $\begin{array}{r}-1.0 \\
1.0 \\
3.0 \\
5.0 \\
7.0\end{array}$ & $\begin{array}{l}86.1 \\
i 23.6 \\
121.6 \\
121.5 \\
127.1\end{array}$ & $\begin{array}{r}80.6 \\
i 2 i .0 \\
118.3 \\
119.3 \\
126.2\end{array}$ & $\begin{array}{l}80.1 \\
i 2 i .3 \\
113.0 \\
114.9 \\
118.5\end{array}$ & $\begin{array}{r}78.9 \\
i<0 . \bar{y} \\
120.2 \\
122.9 \\
127.4\end{array}$ & $\begin{array}{r}78.5 \\
i<4.5 \\
121.1 \\
120.8 \\
126.6\end{array}$ & $\begin{array}{r}76.9 \\
119.9 \\
115.8 \\
117.0 \\
120.8\end{array}$ & $\begin{array}{r}76.4 \\
10 \overline{9} .4 \\
112.8 \\
114.2 \\
116.5\end{array}$ & $\begin{array}{r}78.6 \\
136.1 \\
128.1 \\
130.5 \\
141.1\end{array}$ \\
\hline $\begin{array}{l}13.0 \\
23.0 \\
31.0 \\
41.0 \\
60.0\end{array}$ & $\begin{array}{l}146.3 \\
161.1 \\
170.1 \\
178.6 \\
195.0\end{array}$ & $\begin{array}{l}141.8 \\
156.4 \\
165.5 \\
172.8 \\
189.9\end{array}$ & $\begin{array}{l}139.1 \\
148.7 \\
154.3 \\
167.7 \\
181.2\end{array}$ & $\begin{array}{l}146.2 \\
159.7 \\
169.4 \\
177.3 \\
197.6\end{array}$ & $\begin{array}{l}143.3 \\
158.3 \\
166.9 \\
171.7 \\
190.4\end{array}$ & $\begin{array}{l}138.3 \\
153.0 \\
167.3 \\
180.8 \\
203.5\end{array}$ & $\begin{array}{l}134.1 \\
151.4 \\
166.6 \\
182.6 \\
202.5\end{array}$ & $\begin{array}{l}156.1 \\
174.4 \\
180.9 \\
185.4 \\
205.0\end{array}$ \\
\hline $\begin{array}{r}90.32 \\
120.27 \\
156.23 \\
180.15 \\
240.12\end{array}$ & $\begin{array}{l}145.8 \\
141.5 \\
138.7 \\
138.7 \\
136.6\end{array}$ & $\begin{array}{l}144.1 \\
140.3 \\
138.1 \\
137.5 \\
136.1\end{array}$ & $\begin{array}{l}140.2 \\
137.7 \\
135.9 \\
135.4 \\
134.8\end{array}$ & $\begin{array}{l}147.4 \\
143.4 \\
140.3 \\
141.2 \\
138.4\end{array}$ & $\begin{array}{l}143.9 \\
139.3 \\
138.4 \\
137.0 \\
135.6\end{array}$ & $\begin{array}{l}150.3 \\
145.6 \\
143.3 \\
142.5 \\
139.4\end{array}$ & $\begin{array}{l}151.7 \\
146.4 \\
144.6 \\
142.7 \\
140.3\end{array}$ & $\begin{array}{l}146.6 \\
142.3 \\
139.4 \\
138.7 \\
136.4\end{array}$ \\
\hline $\begin{array}{l}330.15 \\
390.53 \\
480.15 \\
600.60 \\
720.0\end{array}$ & $\begin{array}{l}133.9 \\
131.6 \\
128.1 \\
124.0 \\
120.8\end{array}$ & $\begin{array}{l}133.6 \\
131.2 \\
128.0 \\
123.9 \\
119.8\end{array}$ & $\begin{array}{l}133.1 \\
130.5 \\
127.0 \\
122.9 \\
118.9\end{array}$ & $\begin{array}{l}135.0 \\
132.6 \\
128.9 \\
124.7 \\
120.3\end{array}$ & $\begin{array}{l}132.6 \\
130.4 \\
127.2 \\
122.7 \\
118.8\end{array}$ & $\begin{array}{l}135.6 \\
132.7 \\
128.7 \\
123.9 \\
119.3\end{array}$ & $\begin{array}{l}136.3 \\
133.2 \\
129.0 \\
123.9 \\
119.7\end{array}$ & $\begin{array}{l}133.3 \\
131.1 \\
128.1 \\
123.4 \\
119.2\end{array}$ \\
\hline 840.0 & 117.9 & 116.3 & 115.4 & 116.7 & 115.3 & 115.7 & 115.7 & 115.8 \\
\hline
\end{tabular}

\begin{tabular}{|c|c|c|}
\hline $\begin{array}{l}\text { Average Gas } \\
\text { Temperature } \\
\left({ }^{\circ} \mathrm{F}\right) \\
\end{array}$ & $\begin{array}{c}\text { Standard } \\
\text { Deviation } \\
\left({ }^{\circ} \mathrm{F}\right) \\
\end{array}$ & $\begin{array}{c}\text { Atmosphere } \\
\text { Pressure } \\
\text { (psia) }\end{array}$ \\
\hline $\begin{array}{r}79.51 \\
122.81 \\
118.86 \\
120.14 \\
125.53\end{array}$ & $\begin{array}{l}3.02 \\
7.48 \\
5.08 \\
5.22 \\
7.59\end{array}$ & $\begin{array}{l}17.71 \\
19.06 \\
18.82 \\
18.84 \\
18.97\end{array}$ \\
\hline $\begin{array}{l}143.15 \\
157.88 \\
167.63 \\
177.11 \\
195.64\end{array}$ & $\begin{array}{l}6.66 \\
7.92 \\
7.26 \\
5.99 \\
8.19\end{array}$ & $\begin{array}{l}19.38 \\
19.78 \\
19.99 \\
20.15 \\
20.48\end{array}$ \\
\hline $\begin{array}{l}146.25 \\
142.06 \\
139.84 \\
139.21 \\
137.20\end{array}$ & $\begin{array}{l}3.67 \\
3.01 \\
2.85 \\
2.67 \\
1.94\end{array}$ & $\begin{array}{l}18.94 \\
18.86 \\
18.86 \\
18.86 \\
18.80\end{array}$ \\
\hline $\begin{array}{l}134.18 \\
131.66 \\
128.13 \\
123.60 \\
119.60\end{array}$ & $\begin{array}{l}1.31 \\
1.06 \\
0.74 \\
0.54 \\
0.69\end{array}$ & $\begin{array}{l}18.70 \\
18.64 \\
18.54 \\
18.40 \\
18.18\end{array}$ \\
\hline 116.10 & 0.86 & 18.08 \\
\hline
\end{tabular}

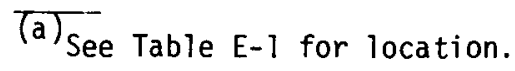


TABLE F-3

WALL STEEL TEMPERATURES IN AB2

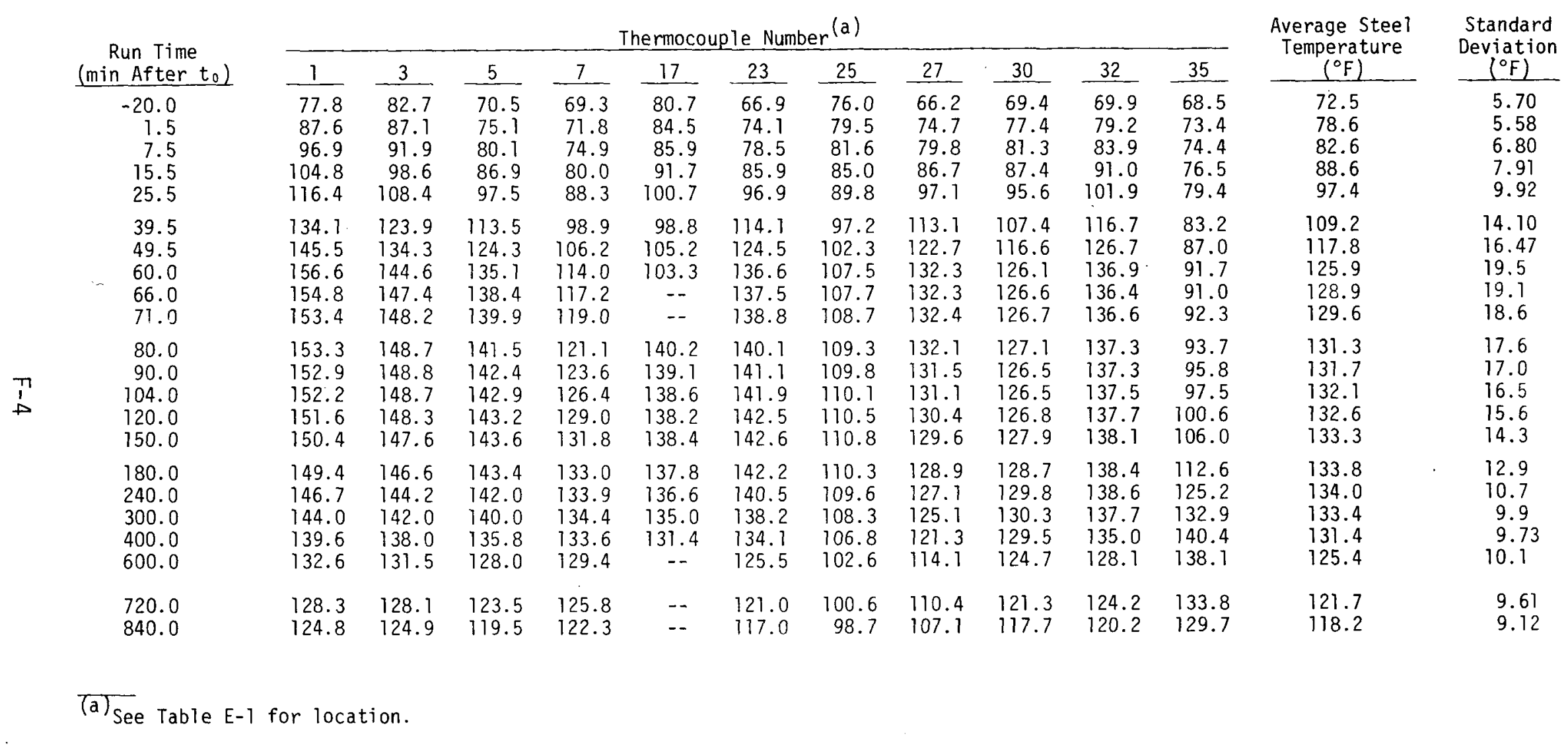

andard iation

5.70

5.58

7.91

9.92

14.10

19.5

8.6

17.6

6.5

15.6

12.9

9.73

61

9.12

(a) See Table E-1 for location. 
TABLE F-4

ATMOSPHERE TEMPERATURES AND PRESSURES IN AB2

\begin{tabular}{|c|c|c|c|c|c|c|c|c|c|c|c|c|}
\hline & \multirow{2}{*}{$\begin{array}{c}\text { Run Time } \\
\text { (min After } t_{0} \text { ) }\end{array}$} & \multicolumn{8}{|c|}{ Thermocouple Number (a) } & \multirow{2}{*}{$\begin{array}{l}\text { Average Gas } \\
\text { Temperature } \\
\left({ }^{\circ} \mathrm{F}\right)\end{array}$} & \multirow{2}{*}{$\begin{array}{c}\text { Standard } \\
\text { Deviation } \\
\left({ }^{\circ} \mathrm{F}\right) \\
\end{array}$} & \multirow{2}{*}{$\begin{array}{c}\text { Atmosphere } \\
\text { Pressure } \\
\text { (psia) }\end{array}$} \\
\hline & & 2 & 22 & 24 & 26 & 28 & 31 & 33 & 44 & & & \\
\hline & $\begin{array}{r}-20.0 \\
1.5 \\
7.5 \\
15.5 \\
25.5\end{array}$ & $\begin{array}{r}50.6 \\
141.9 \\
146.8 \\
156.7 \\
174.0\end{array}$ & $\begin{array}{l}57.6 \\
135.0 \\
141.1 \\
149.0 \\
163.4\end{array}$ & $\begin{array}{r}67.2 \\
122.9 \\
131.2 \\
139.6 \\
152.8\end{array}$ & $\begin{array}{r}57.3 \\
135.5 \\
137.2 \\
148.5 \\
165.2\end{array}$ & $\begin{array}{l}57.3 \\
136.3 \\
140.6 \\
154.3 \\
167.7\end{array}$ & $\begin{array}{r}70.5 \\
135.8 \\
138.4 \\
150.7 \\
167.2\end{array}$ & $\begin{array}{l}70.3 \\
131.3 \\
134.0 \\
147.1 \\
163.9\end{array}$ & $\begin{array}{r}63.0 \\
149.9 \\
149.4 \\
160.2 \\
172.8\end{array}$ & $\begin{array}{r}\text { ธิ. } .50 \\
136.08 \\
139.84 \\
150.76 \\
165.88\end{array}$ & $\begin{array}{l}1.43 \\
7.77 \\
6.09 \\
6.36 \\
6.55\end{array}$ & $\begin{array}{l}\text { iô. 5o } \\
20.55 \\
20.65 \\
20.96 \\
21.43\end{array}$ \\
\hline & $\begin{array}{l}39.5 \\
49.5 \\
60.0 \\
66.0 \\
71.0\end{array}$ & $\begin{array}{l}200.3 \\
204.7 \\
214.4 \\
178.7 \\
169.4\end{array}$ & $\begin{array}{l}189.6 \\
197.0 \\
204.1 \\
170.5 \\
164.3\end{array}$ & $\begin{array}{l}183.3 \\
184.1 \\
193.0 \\
163.2 \\
158.4\end{array}$ & $\begin{array}{l}188.7 \\
197.6 \\
204.5 \\
167.7 \\
161.6\end{array}$ & $\begin{array}{l}191.4 \\
199.0 \\
202.7 \\
166.6 \\
160.8\end{array}$ & $\begin{array}{l}187.8 \\
194.2 \\
202.1 \\
171.6 \\
163.2\end{array}$ & $\begin{array}{l}182.0 \\
189.4 \\
196.9 \\
170.0 \\
163.2\end{array}$ & $\begin{array}{l}202.9 \\
210.4 \\
218.7 \\
173.2 \\
165.5\end{array}$ & $\begin{array}{l}190.75 \\
197.05 \\
204.48 \\
170.19 \\
163.30\end{array}$ & $\begin{array}{l}7.43 \\
8.24 \\
8.30 \\
4.65 \\
3.30\end{array}$ & $\begin{array}{l}21.90 \\
22.10 \\
22.27 \\
21.06 \\
20.95\end{array}$ \\
\hline & $\begin{array}{r}80.0 \\
-90.0 \\
104.0 \\
120.0 \\
150.0\end{array}$ & $\begin{array}{l}164.9 \\
160.5 \\
157.1 \\
155.4 \\
154.7\end{array}$ & $\begin{array}{l}158.3 \\
154.6 \\
152.3 \\
150.3 \\
149.4\end{array}$ & $\begin{array}{l}152.9 \\
150.7 \\
149.4 \\
148.7 \\
148.0\end{array}$ & $\begin{array}{l}156.6 \\
152.9 \\
150.8 \\
148.8 \\
147.9\end{array}$ & $\begin{array}{l}155.4 \\
151.7 \\
149.6 \\
148.2 \\
147.8\end{array}$ & $\begin{array}{l}158.5 \\
154.2 \\
157.5 \\
150.1 \\
149.3\end{array}$ & $\begin{array}{l}157.0 \\
151.5 \\
149.4 \\
148.3 \\
148.3\end{array}$ & $\begin{array}{l}158.7 \\
155.8 \\
154.7 \\
153.7 \\
151.0\end{array}$ & $\begin{array}{l}157.79 \\
153.99 \\
151.78 \\
150.34 \\
149.48\end{array}$ & $\begin{array}{l}3.49 \\
3.15 \\
2.70 \\
2.54 \\
2.16\end{array}$ & $\begin{array}{l}20.81 \\
20.67 \\
20.58 \\
20.51 \\
20.45\end{array}$ \\
\hline & $\begin{array}{l}180.0 \\
240.0 \\
300.0 \\
400.0 \\
500.0\end{array}$ & $\begin{array}{l}151.4 \\
148.6 \\
145.8 \\
140.8 \\
136.4\end{array}$ & $\begin{array}{l}146.9 \\
143.9 \\
141.1 \\
136.4 \\
132.1\end{array}$ & $\begin{array}{l}145.7 \\
142.8 \\
140.2 \\
135.9 \\
131.2\end{array}$ & $\begin{array}{l}145.8 \\
143.2 \\
140.4 \\
135.7 \\
131.1\end{array}$ & $\begin{array}{l}145.4 \\
142.6 \\
140.1 \\
135.2 \\
130.9\end{array}$ & $\begin{array}{l}147.9 \\
145.3 \\
143.2 \\
138.6 \\
134.8\end{array}$ & $\begin{array}{l}147.1 \\
144.8 \\
142.9 \\
138.5 \\
134.6\end{array}$ & $\begin{array}{l}148.6 \\
145.3 \\
142.2 \\
137.1 \\
132.3\end{array}$ & $\begin{array}{l}147.35 \\
144.53 \\
141.98 \\
137.27 \\
132.93\end{array}$ & $\begin{array}{l}1.98 \\
1.94 \\
1.96 \\
1.90 \\
2.06\end{array}$ & $\begin{array}{l}20.35 \\
20.19 \\
20.08 \\
19.89 \\
19.72\end{array}$ \\
\hline & $\begin{array}{l}600.0 \\
720.0 \\
840.0\end{array}$ & $\begin{array}{l}132.7 \\
128.3 \\
124.6\end{array}$ & $\begin{array}{l}127.7 \\
122.9 \\
118.8\end{array}$ & $\begin{array}{l}126.9 \\
122.2 \\
118.0\end{array}$ & $\begin{array}{l}126.8 \\
122.4 \\
118.2\end{array}$ & $\begin{array}{l}126.7 \\
122.0 \\
118.0\end{array}$ & $\begin{array}{l}130.7 \\
126.3 \\
122.1\end{array}$ & $\begin{array}{l}130.5 \\
126.0 \\
121.9\end{array}$ & $\begin{array}{l}128.2 \\
123.2 \\
118.7\end{array}$ & $\begin{array}{l}128.79 \\
124.16 \\
120.04\end{array}$ & $\begin{array}{l}2.23 \\
2.37 \\
2.49\end{array}$ & $\begin{array}{l}19.54 \\
19.26 \\
19.06\end{array}$ \\
\hline
\end{tabular}

(a) See Table E-1 for location. 


\section{DISTRIBUTION}

UC-79 (240)

UC-79p (36)

$\underline{D O E} / R L$

Chief Patent Attorney

DOE/FFTFPO (5)

Director

DOE/RRT-HQ (2)

Program Division Director

HEDL (41)
G. R. Armstrang
$W / C-78$
L. D. Muhlestein
$W / 227-T$
J. M. Atwood
$W / C-45$
J. R. Barreca
$W / 221-T$
F. J. Carvo
$W / 221-T$
W. V. Cook
$W / 221-T$
J. W. Hagan
W/C -78
J. P. Hale
$w / C-76$
R. K. Hilliard
(2) $W / 221-T$
A. R. Hinckley
$W / 227-T$
D. W. Jeppson
$W / 221-T$
A. J. Mahncke
$W / 221-T$
H. C. Martin
$W / C-76$
S. E. Myers
G. W. Oblisk
R. K. Owen
R. D. Peak
A. K. Postma (2)
E. R. Selle
W. F. Sheely
D. E. Simpson
R. M. Steele
D. D. Stepnewski
R. W. Wierman
$W / 221-T$
J. D. McCormack
W/221-T
Central Files (10)
W/221 $-\mathrm{T}$
$W / 221-T$
$W / 221-T$
W/C-75
$W / 221-T$
$W / 221-T$
$W / C-44$
$W / C-80$
$W / 221-T$
W/C -75
$W / 227-T$
$W / C 110$
G. T. McDona $1 d$
Publications Services
(2) $W / C 115$ 